\title{
Lake Bonneville:
}

Geology of

Northern Utah Valley

Utah

GEOLOGIGAL SURVEY PROFESSIONAL PAPER 257-A

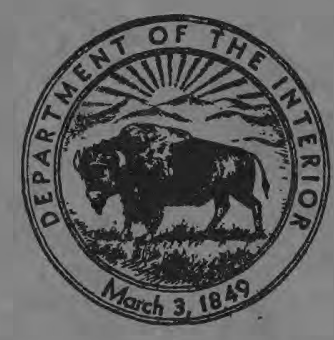




\section{Lake Bonneville:}

Geology of

Northern Utah Valley

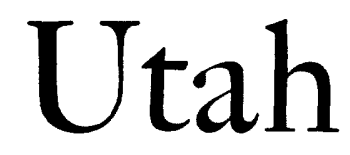

By C. B. HUNT, H. D. VARNES, and H. E. THOMAS

GEOLOGICAL SURVEY PROFESIONAL PAPER 257-A

Stratigraphic, engineering, and water studies

of part of the basin of Lake Bonneville,

one of the great Pleistocene lakes in the

Western United States

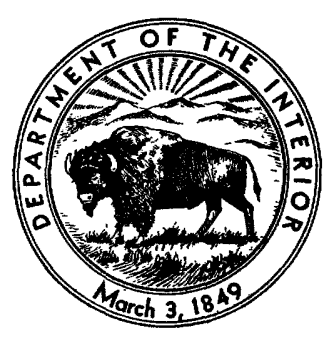

UNITED STATES GOVERNMENT PRINTING OFFICE, WASHINGTON : 1953 


\section{UNITED STATES DEPARTMENT OF THE INTERIOR}

Douglas McKay, Secretary

GEOLOGIGAL SURVEY

W. E. Wrather, Director

For sale by the Superintendent of Documents, U. S. Government Printing Office

Washington 25 , D. C. - Price $\$ 2.25$ (paper cover) 


\section{CONTENTS}

Abstract

Introduction

Acknowledgments..........

Field work and methods . . . . . . . . . . . . . .

Previous studies .

Economic geography

Towns.

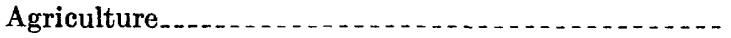

Industry -..............

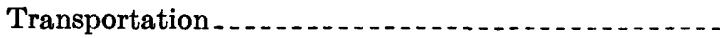

History of settlement and development..........

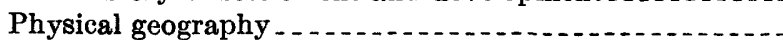

Landforms . . . . .

Climate

General geology, by C. B. Hunt. .

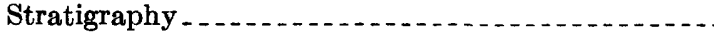

Source rocks in adjoining mountains

Pre-Cambrian, Paleozoic, and Mesozoic rocks _...............

Tertiary(?) rocks . . . . . . . . Little Cottonwood stock ............ Lavas and water-laid volcanics ....... Quaternary deposits in the mountains..... Glacial deposits ...................... Alluvial and other surficial deposits ...

Some relationships between the source rocks and

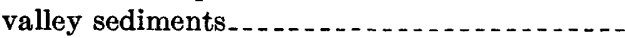

Deposits in Utah Valley

Salt Lake formation (Tertiary) .............

Pre-Lake Bonneville deposits (Pleistocene) .Exposed deposits ................. Concealed deposits

Lake Bonneville group................... Alpine formation ....... . . . .

Gravel member..............

Sand member ..................

Silt and clay member..........

Bonneville formation..............

Provo formation.................

Gravel member.....................

Sand member.................

Silt member....................

Clay member..................

Concealed Pleistocene deposits..............

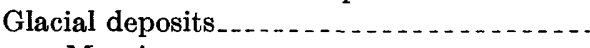
Moraines.......................... Glacial outwash . . . . Alluvial deposits of Provo(?) age .......Post-Provo deposits (Pleistocene? and

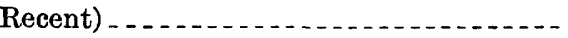
Alluvial deposits Eolian(?) silt..... . . . . . . . . . . . Lake deposits ...................... Vertebrate fossils.
Page
General geology, by C. B. Hunt-Continued Some geochemical problems

Analyses and outline of some of the problems_- $\quad 31$

Comparisons between similar deposits from different sources . . . . .

Comparisons between similar deposits of different age

Comparisons between near-shore and offshore deposits . . . .

Utah Lake...................

Traces of heavy metals................

Salinity of Lake Bonneville . . . . . . . . . .

Calcium carbonate deposits................. Comparative volumes of the formations............. Depth of the valley fill ....... Structural geology . . . . . . Geological history

Origin and structural history of the valley ..... History of sedimentation in the valley.......... Lake Bonneville-a Wisconsin lake............. Evolution of the climate, topography and soils. An estimate of the geologic time and rate of erosion represented by the formations.

Relation of the geology to some soil problems...... Ancient soils ..... Modern soils .................. Saline soils Pleistocene history as a factor in soil genesis . - Some geological aspects of erosion and flood control problems.-...-. Engineering geology, by Helen D. Varnes...........

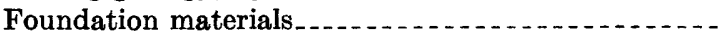

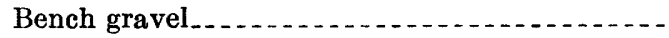
Permeability and drainage .............. Stability Workability

River gravel .......... Permeability and drainage........ Stability Workability

Mixed gravel and sand . . . . . . . . . Permeability and drainage............ Stability

Sand Permeability and drainage Stability

Silt and clay Permeability and drainage ............ Stability

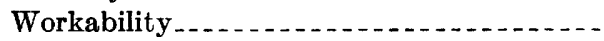

Unsorted materials (alluvial fan deposits) ...... Permeability and drainage ............ Stability _... . . Workability
Page 
Engineering geology, by Helen D. Varnes-Continued Foundation materials-Continued

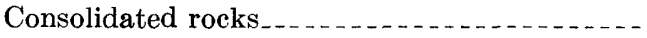

Tertiary formations. . . . . . .

Paleozoic formations . . . . . . . . . . . . .

Construction materials (unprocessed) .............

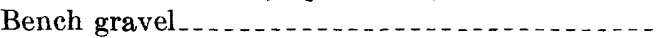

Concrete aggregate Surfacing and base-course materials...... Fill _. . Riprap

River gravel.............. Concrete aggregate Surfacing and base-course materials ....... Fill _. . . . Riprap

Mixed gravel and sand Concrete aggregate................... Surfacing and base-course materials. ...... Fill . . . . .

Sand

Fine aggregate ...................... Surfacing and base-course materials...... Fill

Silt and clay Fill . . . . . . . . . . . .

Binder material ......................

Unsorted materials (alluvial-fan deposits) ......

Concrete aggregate, surfacing, and basecourse .................................

Fill _...

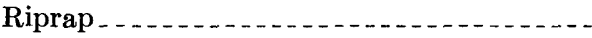

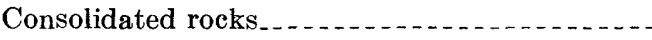

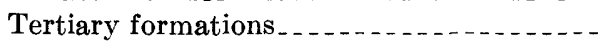

Paleozoic formations ................... Concrete aggregate, base course, sur-

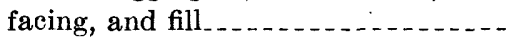

Riprap. . . Limestone for flux. . . . . . . . . . . . Canal lining Construction materials (processed)

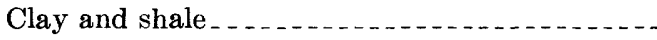

Lake silt and clay

Paleozoic shale

Clay developed on ancient soils, by C. B.

Hunt, A. S. Creamer, and J. J. Fahey ...

Calcareous tufa (travertine)

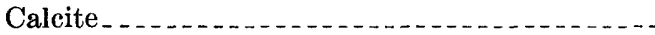

Seismic activity in Utah Valley

Water resources, by Harold E. Thomas........... Introduction . . . .

History of water utilization

Diversions from streams . . . . . . . . .

Use of water prior to 1880

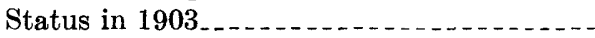

Status in 1947

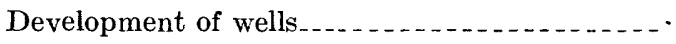
Early history

Status in 1903

Status in 1947
Page

\section{Water resources, by Harold E. Thomas-Continued \\ History of water utilization-Continued}

Reservoir control ...........................

Utah Lake .............................

Deer Creek reservoir . . . . . .

Other reservoirs . . . . . . .

Fluctuations in water supply

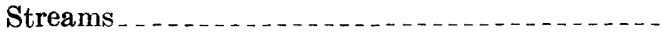

Records of stream discharge

Estimates of surface inflow to northern Utah Valley.

Reservoirs . . . . . . .

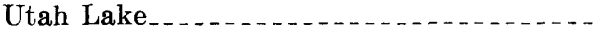

Empirical determinations of natural loss and inflow .....................

Deficiencies in basic data..........

Evaporation .....................

Surface inflow ...................

Subsurface inflow ..............

Deer Creek reservoir

Wells

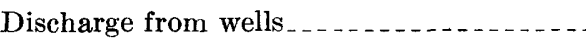

Fluctuations of water level and artesian pressure

Seasonal fluctuations.............. Long-term fluctuations ..............

Relation between fluctuations of water level and total well discharge.......

Springs and drains. ........

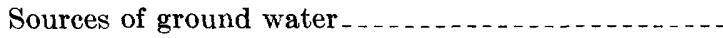

Post-Provo alluvial deposits. .............

Water table

Recharge area.........................

Movement and natural disposal . . . ......

Consumptive use ......................

The problem of pollution

Lake Bonneville group . . . . . .

Water table

Recharge area

Movement and natural disposal .........

Consumptive use ....................

Pre-Lake Bonneville Pleistocene deposits......

Shallow Pleistocene artesian aquifer......

Piezometric surface..............

Consumptive use................

Deep Pleistocene artesian aquifer

Piezometric surface..............

Consumptive use .................

Recharge areas...........................

Movement and natural disposal. ........

Tertiary and Tertiary(?) deposits...........

Characteristics of developed aquifer...... Discharge test of well (D-6-2) 8 bed-4 ....

Source and movement of water in Tertiary(?) aquifers......................

Water from deep sources.....................

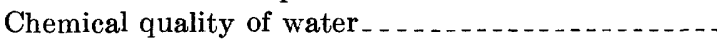

Maximum potential development of water resources_ Selected bibliography

Index
Page

65

65

66

66

66

66

67

68

69

69

69

71

71

71

71

73

73

73

77

77

77

78

78

79

79

80

80

80

80

80

81

81

81

81

81

82

83

83

83

84

84

84

84

85

85

86

86

87

89

89

90

92

97 


\section{ILIUSTRATIONS}

Page

Plate 1. Geologic map of northern Utah Valley, Utah County, Utah

2. Engineering geologic map of northern Utah Valley _.

3. Map of northern Utah Valley showing contours on the piezometric surfaces of artesian aquifers in April 1947, and contours on the water table under the Provo and Highland benches in June 1947 .

4. Geologic sections in northern Utah Valley, Utah .

Figure 1. Index map of Lake Bonneville showing the areas being restudied and mapped

2. Block diagram of northern Utah Valley. View north

3. Rainfall map.

4. Shapes of sand grains

5. Logs of wells at Geneva Steel plant

6. Pattern of gravel beds in Alpine formation at Geneva Steel plant

7. Contour map showing configuration of the base of the clay member of the Provo formation

8. Diagrammatic section along Dry Creek at Alpine

9. Sketch map showing location of samples collected for chemical analyses.

10. Diagrammatic section to illustrate some relationships between the geology and soil development

11. Cross section showing bedding in delta front

12. Cross section showing bedding in post-Provo river-laid gravel deposits

13. Mechanical analyses of silt and clay in northern Utah Valley

14. Map showing location of pits and quarries in northern Utah Valley

15. Map showing differences in types of gravel in northern Utah Valley

16. Hydrographs showing discharge of American Fork River and South Fork of Provo River, and increase in flow of Provo River below Vivian Park

17. Correlation of stages of Utah Lake with precipitation and with inflow and outflow of the lake

18. Hydrographs of four wells in northern Utah Valley

19. Artesian aquifers of Pleistocene pre-Lake Bonneville deposits

20. Monthly discharge from three spring areas in northern Utah Valley, 1937-40

21. Discharge and drawdown during test of well (D-6-2) 8bed-4, April 16, $1948 \ldots$

22. Chemical analyses of water from wells of the Geneva Steel Co

\section{TABLES}

TABLE 1. Annual precipitation at weather stations in or near northern Utah Valley

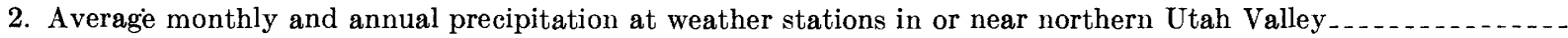

3. Average evaporation

4. Complete analyses of silt and clay from Provo formation northwest of Dry Creek

5. Complete analyses of silt and clay from Provo formation southeast of American Fork River.

6. Complete analyses of silt and clay from Alpine formation

7. Analyses of water-soluble salts in Alpine and Provo formations

8. Analyses of water from Utah Lake.

9. Proportions of certain constituents in the Provo formation in different parts of the valley

10. Proportions of water-soluble salts in the Provo formation in different parts of the basin.

11. Proportions of certain constituents in lake-bottom deposits of parts of Provo and Alpine formations that had a common source.

12. Proportions of water-soluble salts in the Provo and Alpine formations $-x$

13. Distribution of water-soluble salts in silt and clay facies of the Alpine formation

14. Distribution of water-soluble salts in silt and clay facies of the Provo formation

15. Traces of heavy metals in Provo and Alpine formations

16. History of principal stream diversions prior to 1880 in northern Utah Valley

17. Classifications of wells in northern Utah Valley in 1947.

18. Number of wells in northern Utah Valley by years.

19. Stream-discharge records for northern Utah Valley

20. Estimated surface inflow to northern Utah Valley

21. Annual changes in storage, inflow, and outflow of Utah Lake.

22. Surface inflow to and discharge from principal alluvial fans of northern Utah Valley

23. Water yielded annually by wells in Highland district, 1938-40

24. Water yielded annually by wells in Provo district, 1938-40

25. Changes of water levels in observation wells

26. Multiple-step drawdown test of Geneva Steel Co. well (D-6-2) 8bcd-4, April 16, 1948.

27. Mineral content and hardness of water in streams, and in aquifers of different depths at Geneva, Utah

28. Annual inflow to Utah Lake at Geneva Steel plant.
Page 



\title{
LAKE BONNEVILLE: GEOLOGY OF NORTHERN UTAH VALLEY, UTAH
}

\author{
By Charles B. Hunt, Helen D. Varnes, and Harold E. Thomas
}

,

\section{ABSTRACT}

Lake Bonneville was a vast Pleistocene lake that covered 20,000 square miles in northwestern Utah and had a maximum depth of about 1,000 feet. It was a body of water comparable in size to modern Lake Michigan.

Surveys of the unconsolidated deposits in the Lake Bonneville basin utilize the same methods used in studies of hard rocks, namely: separation of the deposits into mappable units and determination of their stratigraphic sequence; lateral tracing of contacts between formations; observations of lateral and vertical changes in lithology; and plotting of these data on the map.

The sedimentary deposits in Utah Valley were derived from the adjoining mountains which are composed very largely of limestone and quartzite but include some granite and extrusive rocks. The stratigraphy of the deposits in northern Utah Valley is summarized as follows:

Tertiary and Quaternary formations in northern Utah Valley

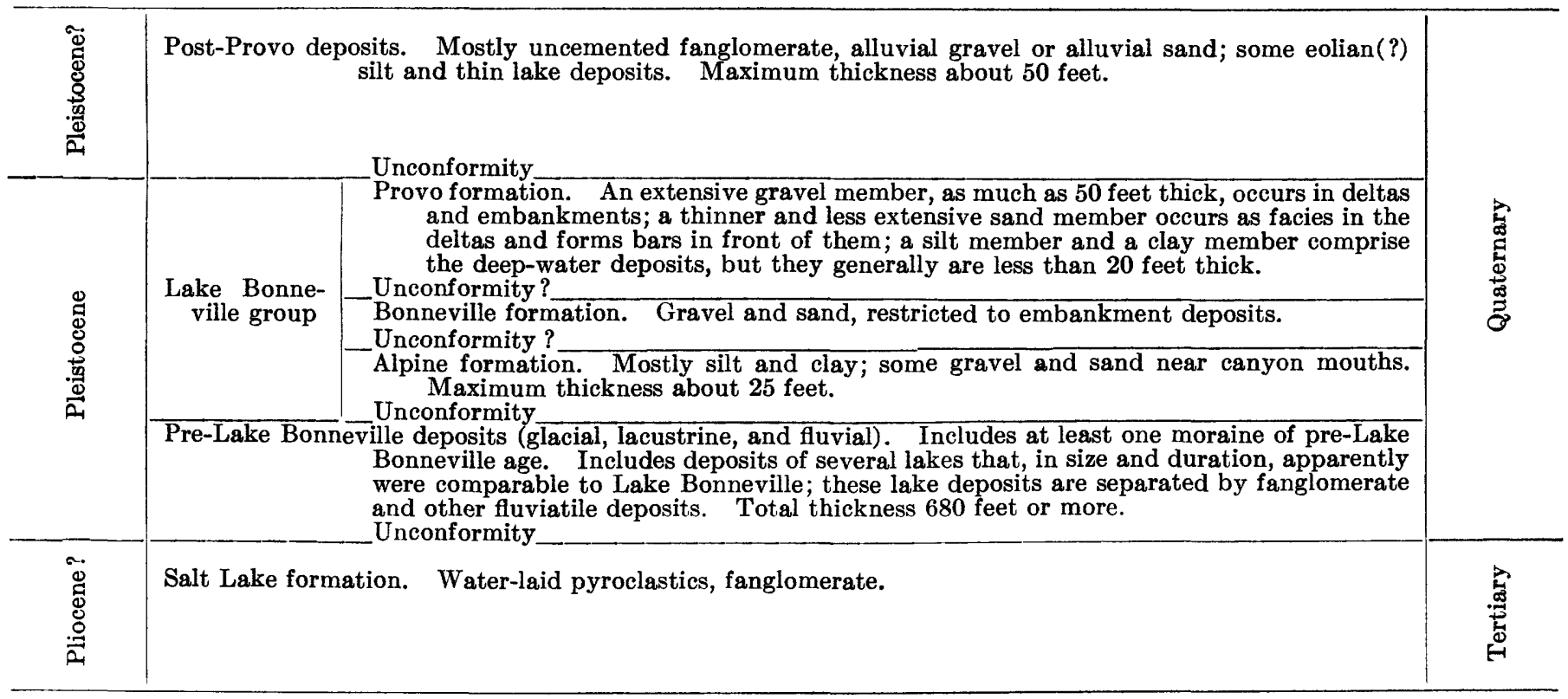

Utah Valley is a structural valley bounded by faults and undoubtedly is the result of faulting primarily, although folding or tilting may have contributed to the displacement. Rocks in the mountains around the valley are intensely deformed, largely because of the folding, overthrusting, and other faulting that occurred during the Cretaceous and probably also during early Tertiary time. The valley, however, is largely the product of later structural movements that gave rise to block faulting.

These later movements apparently began in middle or late Tertiary time and continued intermittently throughout Quaternary time. The earliest record of sedimentation in the valley is represented by the tuffs, related volcanics, and other sediments of the Salt Lake formation. During Pleistocene time several lakes comparable in magnitude to Lake Bonneville, but earlier, flooded the valley. These lakes presumably correlate with the early glacial periods. The faults that bound the valley displace these early Pleistocene deposits less than the Tertiary deposits, and more than the Lake Bonneville group.

Lake Bonneville was a product of the last glacial period and is believed to be of Wisconsin age. Outwash from the youngest moraine at the mountain front is interbedded with the Lake Bonneville group. The earliest deposits of the Lake Bonneville group, the Alpine, which is composed chiefly of clay and silt, is believed to represent the erosion of an ancient and deep soil from the mountains. The younger formations, which contain a higher proportion of rock fragments, apparently record a change of climate that resulted in erosion becoming dominant over weathering in the mountains.

The record of the several glaciations in the mountains and of the several lakes in the valleys clearly shows wide fluctuations of past climates. The rates of erosion and sedimentation under the different climates are not known, but one fact does become 
apparent-either the rates of erosion and sedimentation in the past must have exceeded by several times the rates since Lake Bonneville time, or the Pleistocene epoch must have been several times longer than generally has been thought.

The fluctuations in climate that are recorded in the geology are also recorded in the soils of the area. Some ancient soils that formed in pre-Lake Bonneville time have been recognized. These are wholly different from modern soils. The ancient soils are as deep as 30 feet; they consist of an upper layer of limefree illitic clay and an underlayer of weathered parent material that is strongly lime-impregnated. The modern soils have only feebly developed profiles and rarely are more than a very few feet deep. In the ancient soils the parent material is entirely altered to clay in the upper layers; in the modern soils the alteration consists of little more than a slight transfer downward of water-soluble salts, and the parent material still dominates all layers in the profile.

A considerable number of chemical analyses of the Lake Bonneville sediments were made in the Chemistry Laboratory of the U. S. Geological Survey. Some of the principal relationships brought out by the analyses are the following:

1. There is considerable similarity in the chemical composition of contemporaneous deep-water deposits that had different sources, indicating that the rate of settling of sediment in the deep-water parts of the lake was sufficiently slow to permit rather thorough mixing of the sediments.

2. The content of water-soluble salts in the younger of the Lake Bonneville group (Provo formation) is considerably greater than in the older deposits (Alpine formation), evidently indicating that Lake Bonneville became increasingly saline as it diminished in size.

3. The quantity of water-soluble salts increases shoreward in the older of the Lake Bonneville group (Alpine formation), whereas it decreases shoreward in the younger deposits (Provo formation).

Calcium carbonate deposits in Utah Valley are of at least four kinds: spring deposits, deposits at headlands in the old lake evidently derived from the lake waters, deposits at the top of a fluctuating water table, and deposits formed by soil processes.

Adequate data on the kind and distribution of the earth materials that make up Utah Valley facilitate the location of construction materials such as gravel, sand, and riprap, and can be used in making preliminary estimates on excavation and fill requirements. Subsidence of foundations and roads, excessive leakage in irrigation ditches, and similar problems are directly tied to the geologic environment; hence, knowledge of the geology affords an explanation of the source of these troubles in the case of already existing structures and makes it possible to foresee and prevent them in new construction.

The manner in which materials are used largely determines which of their properties are significant. A description of the engineering geology summarizes the engineering properties of the formations in three categories: foundation materials; construction materials that are unprocessed except by screening or washing; and construction materials that are processed in some manner, such as the burning of clay for brick or tile, or the dressing of building stone.

The chapter on water resources reviews the history of water utilization and describes what is known about the fluctuations in the water supply, both as to surface water and ground water. The principal developed sources of ground water in the valley are the pre-Lake Bonneville Pleistocene deposits. Important sources also have been developed in older, possibly Tertiary, deposits. Small amounts are developed also from the Lake Bonneville and younger deposits.

\section{INTRODUCTION}

The intermontane valleys in the Basin and Range province have received little study and probably are the least known geologically of any valleys in the United States. Yet a wealth of Quaternary and Tertiary stratigraphic and structural history can be gleaned from these valleys, for they contain the positive depositional record of the periods that in the mountains are represented by erosion.

A comprehensive and classic study of the whole Bonneville Lake basin was made by G. K. Gilbert during the latter part of the last half century, but his methods were necessarily of a reconnaissance nature. In 1946, the U. S. Geological Survey began a series of detailed studies in order to map the basin systematically and to obtain fuller information about its geological history and resources. This report, together with the accompanying map, covers that part of the Bonneville Lake basin lying in the north half of Utah Valley, an area embracing about 150 square miles (fig. 1), and is the first of a series of studies of Lake Bonneville.

The work was undertaken largely as an experiment to develop methods and techniques for mapping poorly exposed unconsolidated deposits. As the work progressed, it became increasingly evident that mapping unconsolidated deposits in an area like Utah Valley is no different from mapping poorly exposed hardrock formations. The methods and techniques used are described in a following section of the report.

Probably the most important contribution of this experimental study is that it has provided impetus to a program for the systematic mapping of the Lake Bonneville, Lake Lahontan, and other basins in the Basin and Range province. Encouraged by the results of the Utah Valley investigation, the Geological Survey has undertaken similar projects in adjoining areas and similar work has been started in the Lahontan Basin. It is hoped that these are but the first of a series of reports leading to the complete systematic mapping that is so much needed in these old basins.

\section{ACKNOWLEDGMENTS}

The members of the Geology Departments at the University of Utah, Brigham Young University, and Utah State Agricultural College provided much stimplation and encouragement during the study. Their interest and cooperation were of material assistance, as were the facilities that they made available in connection with the field studies.

During the field work much pleasure and profit was derived from field conferences with numerous members of the U. S. Geological Survey; their criticisms and suggestions were most helpful, especially those of A. A. Baker, who has been studying and mapping in the 


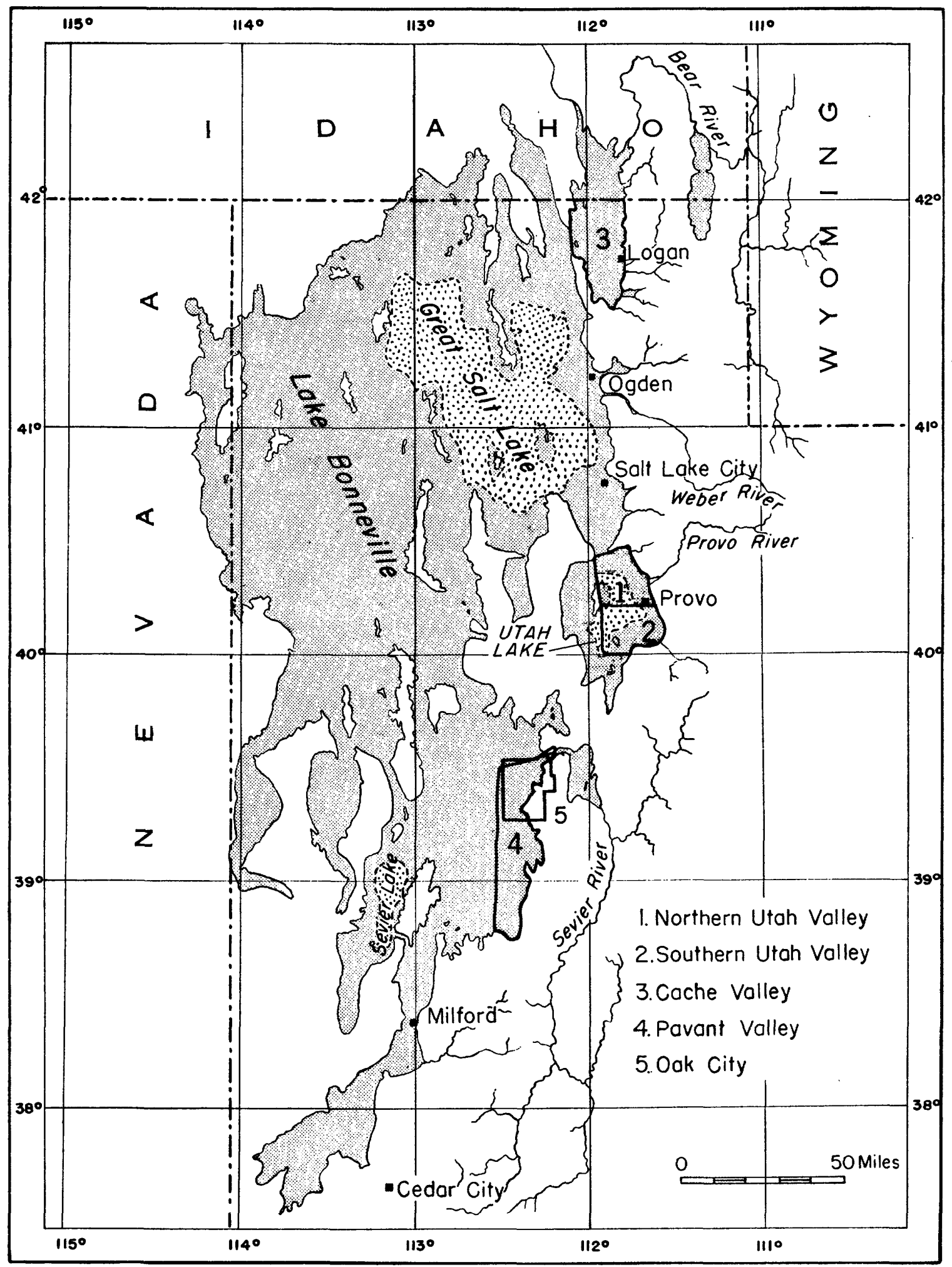

FIGURE 1.-Index map of Lake Bonneville showing the areas being restudied and mapped. 1. Northern Utah Valley; 2. Southern Utah Valley; 3. Cache Valley; 4. Pavänt Valley; 5. Oak City area. 
Wasatch Range east of Utah Valley, and Roger B. Morrison, who has been mapping and studying the Carson Sink area in the Lake Lahontan Basin, Nevada.

Geoffrey B. Bodman, of the Division of Soils, College of Agriculture, University of California, spent 3 days in the area in connection with some of the soils problems, and he has contributed analyses as well as many helpful criticisms and suggestions about that phase of the study.

Personnel of the Pleasant Grove office of the Bureau of Reclamation were very cooperative and contributed much data useful in the chapter on engineering geology. Mr. Richard Van Horn assisted both in the field and office during the summer and winter of 1947 , especially in connection with the engineering geology study. Mr. David Varnes assisted in this phase of the study also for about 3 weeks in 1947.

\section{FIELD WORK AND METHODS}

The field work for this report was done intermittently during the period January 1946 to September 1947.

Fortunately there was available an excellent topographic map which served as a base. This map, surveyed in 1922 and 1925 by the Geological Survey in cooperation with Utah County and the Bureau of Reclamation, is on a scale of $1: 24,000$; it has a contour interval of 5 feet except near the lake where the contours were surveyed at 1-foot intervals. Without this excellent base, the geologic mapping in Utah Valley would have been slow, tedious, and much more costly. In addition to the base map there were available some aerial photographs covering the edges of the valley.

The mapping of unconsolidated deposits like those in Utah Valley involves the same principles as does the mapping of bedrock formations. Separation of the deposits into mappable units, superposition of beds, lateral tracing of contacts between formations, observations of lateral and vertical changes in lithology, and plotting of these on the map are the cardinal principles that must be followed.

In a basin like Utah Valley good outcrops are few, and in many places the position of the formation boundaries must be inferred. Accurate mapping, therefore, would require extensive trenching or augering, but such work was not possible during the study. In lieu thereof it generally was necessary to infer the positions of contacts and in some places even to infer the nature of the lithology of the formation by mustering every kind of evidence that could be brought to bear on the problem.

In the absence of outcrops the most useful tool for this kind of mapping is soil texture and composition, especially where the soils are feebly developed or immature. Variations in ground drainage conditions, such as the distribution of seeps, throw light on the geology. Landform is another valuable tool. For purposes of geologic mapping none of these is exact but the collective evidence such observations furnish plus occasional outcrops are sufficient to reveal the principal elements in the geologic pattern. Contacts traced laterally by following variations in soil or ground drainage generally lead the observer to exposed contacts that reveal the lateral relationship and relative age of the deposits being traced.

The mapping of gradational or poorly exposed formation boundaries commonly is difficult and is especially difficult in deposits like these. For example, the pre-Lake Bonneville deposits below 5,100 feet in altitude were reworked by the waves and currents of the old lake. What degree of reworking should be the criteria for separating the reworked from the parent material? Our practice was to map the reworked material as a separate formation only where it forms a deposit more than 18 inches deep that has texture, composition, or bedding distinctive from that of the original deposit. In the absence of good outcrops the distinctions commonly must be made on the basis of rather subjective interpretations with the result that the map fails to show some embankment deposits that were transported only short distances. Another result, an inevitable one, is lack of complete consistency.

In order to show the relation of one deposit to another, two kinds of formation boundaries are distinguished on the map. Contact lines having hachures on one side indicate contacts of overlap; the hachures are drawn on the side of the younger and overlapping beds. Contact lines without hachures represent changes in facies, a condition that cannot properly be represented by a line on a map. In much of the area, however, not only the position but the nature of the contact has to be based on interpretation rather than on direct observation.

Landforms were not mapped. Wave-cut terraces for example were ignored, except as these provided the site for the accumulation of a distinctive and mappable deposit of sediment.

The first step in mapping a given part of the area was to observe the variations in ground texture. On flat areas such as the surfaces of the deltas and on the broad low fans or lake bottom sediments the soils were distinguished by whether they were composed largely of gravel, sand, silt, or clay. After mapping the ground texture in a few square miles, the boundaries between the different types of ground were walked and the locations were plotted on the map. In general it was necessary to zigzag back and forth across the boundary, and the position of the boundary might be highly uncertain even after such a traverse. It was found, however, that by tracing the boundaries in this 
way across the flat areas, they generally led to gullies or other places where an outcrop of the contact could be examined. At the outcrops the age relations and the overlap or lateral gradation of the one bed into the other could be established. It was not possible to correlate one outcrop with another except by laterally tracing the variation in the soil texture.

The origin of a deposit generally can be judged if its shape and its internal structure and composition are known. Much can be deduced from the internal structure and composition alone, but shape is probably the most reliable single criterion and, in an area like Utah Valley, this can be ascertained only by mapping.

Qualitative chemical analyses of the fine-grained sediments were made in the field to test the distribution of soluble salts in the several formations in order to provide a basis for selecting samples for quantitative analyses.

\section{PREVIOUS STUDIES}

The Bonneville Basin occupies a unique place in the science of geology. The classic description of it, including an analysis of lake processes, is that of $\mathrm{G}$. K. Gilbert (1890). Gilbert's report on Lake Bonneville represents the only comprehensive study that has been made of the basin as a whole. References to the old lake, however, are made in the reports of the numerous other exploratory surveys in the region, and there have been many subsequent papers dealing with special or local problems. A selected bibliography at the end of this volume contains a list of references for the Bonneville Basin and related problems in other areas.

\section{ECONOMIC GEOGRAPHY}

Utah Valley has been primarily an agricultural area but the establishment of the Geneva Steel plant there has increased the likelihood that the valley will become industrialized and that it will develop a more balanced economy.

\section{TOWNS}

Provo, Utah's third largest city, had a population of almost 20,000 in 1940 and is considerably larger now. It is one of the major agricultural, industrial, and educational centers in the West, the service center for an extensive and rich agricultural area and for the Geneva and Ironton Steel plants, and the home of Brigham Young University. Other towns north of Provo are principally agricultural centers. All have grown considerably in the last few years; their populations in 1940 were as follows: Alpine, 444; American Fork, 3,333; Lehi, 2,733; Orem, 2,914; and Pleasant Grove, 1,941 .

\section{AGRICULTURE}

The valley lands are highly productive and annually yield rich crops of grains, fruits, and vegetables. The agricultural economy would seem to be healthy judging from the fact that the majority of the farmers own their own lands. Most of the productive land is irrigated, but some areas are dry-farmed.

\section{INDUSTRY}

Packing plants and canning factories are numerous. Each year they ship large quantities of farm produce to all parts of the United States. Considerable sand and gravel is produced for concrete aggregate, for foundations, and for road metal. (See fig. 14.) The Provo Brick and Tile Co. utilizes clay from along the Provo River; other brick clay is quarried from older shale formations in the west part of the valley at the foot of the Lake Mountains. Refractory brick, made from silica sand brought from other parts of the State, is manufactured north of Lehi.

Heavy industry became established in Utah County in 1924 when the Columbia Steel Co. started its plant at Ironton, 4 miles south of Provo. In 1946 the Geneva Steel plant, which was constructed during World War II, was converted to peacetime production. Electricity is generated at hydroelectric plants located at the mouths of canyons that drain the mountains and at a steam-generating plant in Provo.

\section{TRANSPORTATION}

The area is served by two railroads, the main line of the Denver and Rio Grande Western Railroad Co. and a branch line of the Union Pacific Railroad. The network of roads, mostly following section or quartersection lines, is extensive. Main roads are paved and the principal side roads are metalled. A single trunk highway, which represents the combined United States Highway Nos. 50, 89, and 91, crosses the area. At Provo this connects with U. S. 189. Provo Airport is serviced by the Frontier Airlines.

\section{HISTORY OF SETTLEMENT AND DEVELOPMENT}

Archeological studies in Utab Valley have not as yet disclosed any very extensive prehistoric settlement by the Utes, Paiutes, or their predecessors. The Indians encountered by early white visitors were lazy and shiftless as compared with tribes met elsewhere and their numbers were small. They lived by hunting and fishing and by gathering native fruits, berries, or roots, but apparently they did not till the ground. Some had homes built of earth and grass, others lived in wickiups. Flint chips, imperfect arrowheads, and other tools are abundant locally in the valley but none were found in the Lake Bonneville deposits. 
The first white men known to have entered Utah Valley were the Spanish priest-explorers Padre Escalante and Padre Dominguez. They entered the valley at its south end by way of Spanish Fork on September 23, 1776, while exploring a route from Santa Fe, N. Mex., to Monterey, Calif. (Auerbach, 1943, pp. 64-66.) These explorers turned southward from Utah Valley and did not visit Great Salt Lake, although the Utes spoke of it, saying that its salt waters are injurious and "he who wets any part of his body with this water immediately feels an itching in the wet part." (Bancroft, 1889, p. 15.)

In the early 1820's began the epoch of the fur hunters, and names like William $\mathrm{H}$. Ashley and Jedediah Smith take their place in the chronicle of Utah Valley history. Ashley's Rocky Mountain Fur Company built a fort by Utah Lake, which was known for a while as Ashley Lake, but a year later Jedediah Smith applied the name "Utah Lake" (Bancroft, 1889, pp. 20-22). Provo River and Provo City were named for Etienne Provost, one of the fur hunters whose name has given rise to many legends. (American Guide Series, 1942.)

The Mormon settlers in the valley of Great Salt Lake lost no time in exploring the possibilities for establishing settlements in adjacent or nearby areas, including Utah Valley. Utah Valley was thus explored as early as 1847 (American Guide Series, 1942; Shelley, 1945; Bancroft, 1889; and Huff, 1947). In 1849, because of troubles with Indians, Col. John Scott and a company of 31 men moved into Utah Valley and engaged one of the thieving Indian bands encamped at the site of Pleasant Grove. Several Indians were killed or wounded in this engagement (American Guide Series, 1942, pp. 39-40). The incident is commemorated by the name Battle Creek, the original name of Pleasant Grove and the name still used for the.canyon east of town.

Provo, first named Fort Utah, was settled in 1849 and by the beginning of 1851 had several hundred inhabitants.

Pleasant Grove, originally called Battle Creek; Alpine, which at first was called Mountainville; American Fork, which was called Lake City; and Lehi were settled in 1850 (Huff, 1947, pp. 161, 190, 231, 268). Orem was settled about 1886 (Am. Guide Ser., 1942 , p. 160). All the towns except Orem were located originally alongside or near streams that flow into the valley from the Wasatch Mountains, and the development of Orem followed the construction of a canal to irrigate lands on the Orem bench. The towns were settled as agricultural communities. In all of Utah Valley, 59 square miles of land were under cultivation by 1877 (Powell, 1879, p. 124). Because of the sparse rainfall during the growing season, practically all this area was dependent upon water from streams and springs for irrigation. The history of the development of water supplies and their relation to the present economy of the valley is discussed further on pages 60-91.

Utah Valley first became serviced by through railroads in 1873 when the Utah Railway built a connecting line southward from the transcontinental railroad at Salt Lake Valley. The Denver and Rio Grande Western Railroad was completed in 1883.

Almost from the beginning large-scale reclamation measures were undertaken to bring the maximum amount of arable land under irrigation. As early as 1854 the Territorial Legislature authorized .construction of a 40-mile canal to carry water from Utah Lake onto lands in Salt Lake Valley. Pleasant Grove, American Fork, and Lehi began sharing the water of American Fork River in the early 1850's and constructed irrigation ditches necessary for supplying the towns (Shelley, 1945, pp. 31-35). These and other early attempts to make surface water available for irrigation purposes have culminated today in the Deer Creek and related projects by the Bureau of Reclamation.

\section{PHYSICAL GEOGRAPHY}

\section{IANDFORMS}

The Basin and Range province extends from the foot of the Wasatch Range westward to the foot of the Sierra Nevada. Utah Valley is at the foot of the Wasatch, at the easternmost edge of the province.

The Valley was a bay in the basin of Lake Bonneville (fig. 1). Below the high-water level of the old lake, at about 5,100 feet altitude, the landforms are mostly those built of lake deposits; above 5,100 feet the landforms are mostly those of fluviatile erosion or sedimentation. The contrast is striking even to the untrained observer. Both in detail and in general pattern the landforms of Utah Valley (fig. 2) conform with those so masterfully described by G. K. Gilbert (1890, pp. 23-170) for the Bonneville Basin as a whole.

In the central part of the valley, covering one-fourth or one-fifth of the whole valley floor, is Utah Lake, a body of fresh water. This is a natural lake that is drained by the Jordan River, a tributary of Great Salt Lake which drains Utah Valley through a gorge commonly known as the "Narrows". Today Utah Lake is used as a reservoir to serve the needs of about 48,000 acres of irrigated lands in Jordan Valley which lies north of Utah Valley. Natural storage in the lake has been increased by a small dam across the Jordan River in the Narrows. The lake level may be lowered as much as 9 feet below the natural outlet of the lake by 


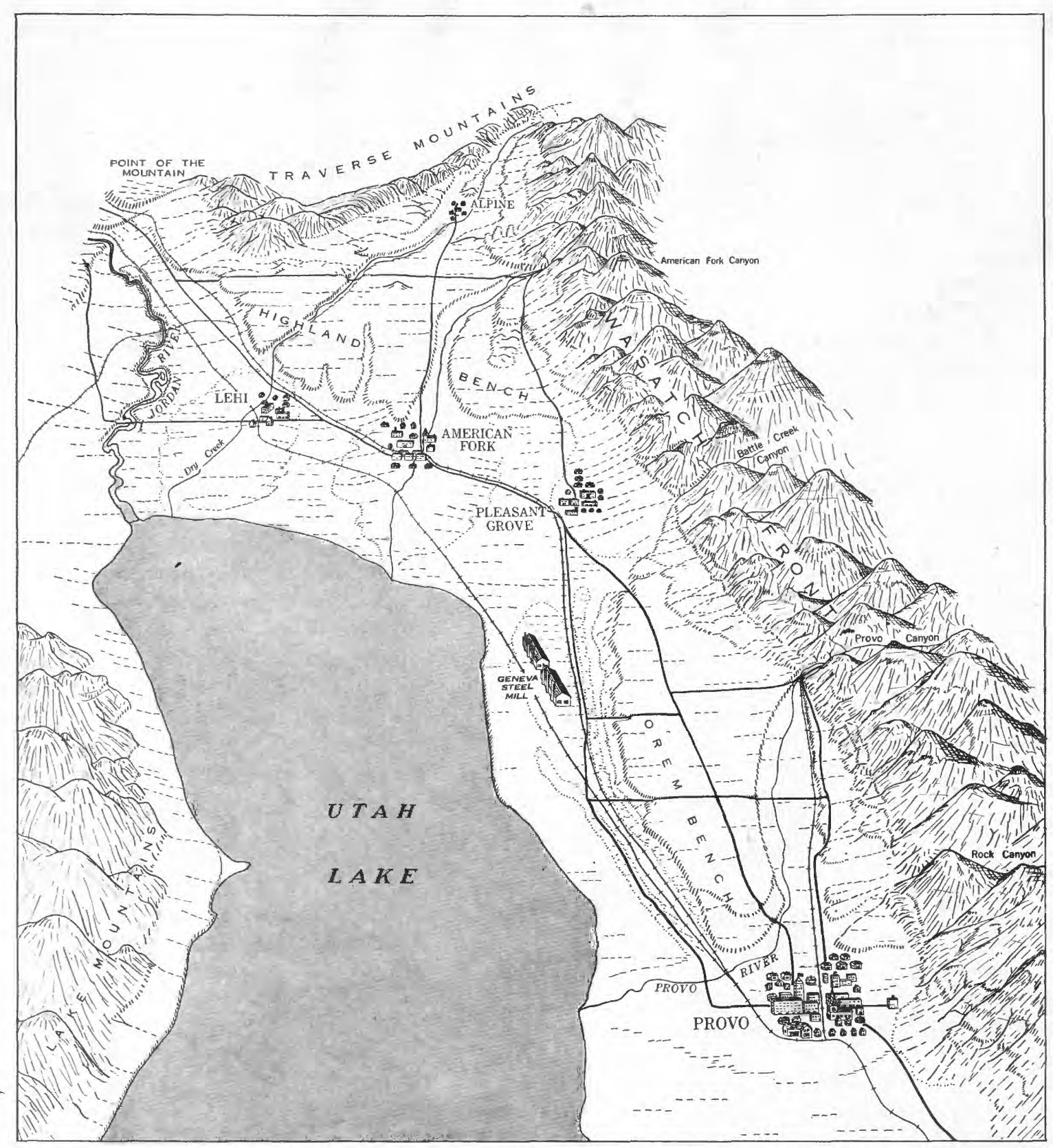

Figure 2.-Block diagram of northern Utah Valley. View north. (Drawn by D. Fishburn.)

means of pumps which are operated throughout each irrigation season (pp. 65-66).

Because the shores slope very gradually small fluctuations in lake level cause considerable shift in the position of the shore. The shores and bottom are more muddy than sandy. The position of the shore as shown on plate 1 is approximately the position of the 4,490-foot lake level.

Rising northward from the shore of the lake is a broad plain that extends about 3 miles to the foot of a bluff that forms the south edge of the Highland bench (fig. 2). The plain rises about 30 feet per mile, and at the foot of the bluff its surface is 100 feet higher than the lake. The plain is formed by the deposits of silt and clay that accumulated on the bottom of Lake Bonneville. At American Fork and at Lehi broad low alluvial fans rise above the surface of the plain; the fan at American Fork is 3 miles wide and 50-75 feet high, the one at Lehi is 2 miles wide and 30-40 feet high.

Overlooking the plain and the fans are bluffs about 100-150 feet high at the south edge of the Highland bench. The surface of the bench rises smoothly northeastward about 200 feet in 3 miles, to the foot of the steep slopes at the base of the mountains. The bench is a delta deposit built in Lake Bonneville by two streams American Fork and Dry Creek, which drain 
from the Wasatch Range. The streams are now in valleys cut 50 feet deep across the old delta. Except for the four small valleys entrenched in the bench (pl. 1) and minor gullying along the bluffs in front, Highland bench faithfully preserves its original deltaic form. The trend and slope of the bluffs is controlled by the dipping foreset beds; the smooth surface of the bench is built of topset beds.

Along the east side of Utah Lake is a low plain similar in form and orgin to that at the north, except that it is only 2 miles wide; west of the Geneva Steel plant, it ends in a 15 -foot bluff at the lake shore. The east and higher part of this plain is interrupted by several north-trending ridges a few hundred feet wide and from 5 to 10 feet high. These ridges are built of sand and represent old bars deposited on the lake bottom silt or clay. At many places the sand has been whipped into small dunes. The plain ends eastward at the foot of Orem bench.

Orem bench, like the Highland bench, is built of the delta deposits brought into Lake Bonneville by Provo River. The bluffs along the west edge are 125 feet high. The surface of the bench rises smoothly 125 feet in 3 miles to the steep slopes at the foot of the mountains. This surface is cut by the valley of Provo River, which is 75 feet deep. The town of Provo is on a broad low alluvial fan on the plain south of the bench.

The west side of Utah Lake is quite unlike the other sides. Bluffs 10 to 15 feet high form the lake shore and from there the surface, formed chiefly on alluvial fans, rises 600 feet in a mile to the foot of the mountains. In general these alluvial fans preserve their fan form although they are older than Lake Bonneville. Here and there the surface is interrupted by wave-cut or wave-built terraces that parallel the contours.

Bordering the valley on the east is the lofty Wasatch Range that rises precipitously to altitudes considerably more than a mile above the valley floor. The three largest streams in the area, Provo River, American Fork River, and Dry Creek, drain from these mountains into the valley. All the mountain streams except Dry Creek flow in narrow V-shaped, rocky gorges typical of fluviatile erosion. Dry Creek, above the town of Alpine, is in a glaciated valley and its cross section is U-shaped.

Across the north edge of the valley are the Traverse Mountains, which consist of smoothly rounded hills, wholly unlike the Wasatch. Their summits are about 2,000 feet higher than the valley. At the Jordan Narrows the Traverse Mountains are broken by the gorge through which the Jordan River flows from Utah Valley to Great Salt Lake.

West of Utah Lake are the Lake Mountains, higher and rougher than the Traverse, but not so high as the
Wasatch. North of the Lake Mountains is a low pass by which Utah Valley is connected with Cedar Valley, the next valley west.

The western part of Utah Valley is rather typical of the Basin and Range province. Water there is scarce and streams are lacking. The eastern part is not typical, in that it adjoins large mountains from which large perennial streams drain into the valley.

\section{CIIMATE}

The present climate of northern Utah Valley is temperate and semi-arid but the climate of the past has differed considerably from that of the present time. The climatic changes that have occurred have been a major factor in controlling the natural processes that have operated in the past and that are operating now in the valley. In this section of the report are given the data pertaining to the present climate; interpretations about the past climates are given in the section on the geologic history of the area (pp. 39-42).

The following tables summarize some of the data collected by the Weather Bureau in and adjacent to northern Utah Valley. Precipitation increases and temperatures decrease eastward across the valley. In the Wasatch Range temperatures are lower and precipitation greater than in the valley. As shown by table 1, the average annual precipitation ranges from about 11 inches in the western part to nearly 17 inches along the base of the Wasatch Range. Recorded extremes since 1891 have been 5.94 inches in 1933 at Utah Lake near Lehi, and 29.22 inches in 1906 at Alpine. These geographic variations in the climate are illustrated, in part, in figure 3.

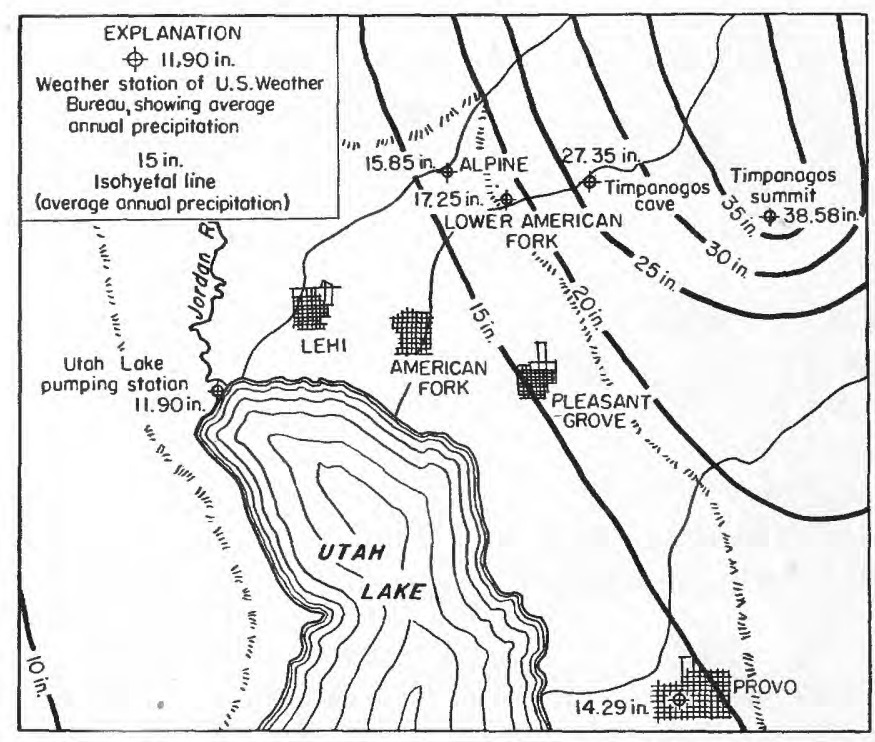

FIGURE 3.- Map showing variations in average annual precipitation in northern Utah Valley and adjoining mountains. Compiled from U. S. Weather Bureau data. 
GEOLOGY OF NORTHERN UTAH VALLEY, UTAH

$\mathrm{T}_{\mathrm{ABLE}}$ 1.-Annual precipitation at weather stations in or near northern Utah Valley

[Data from U. S. Weather Bureau]

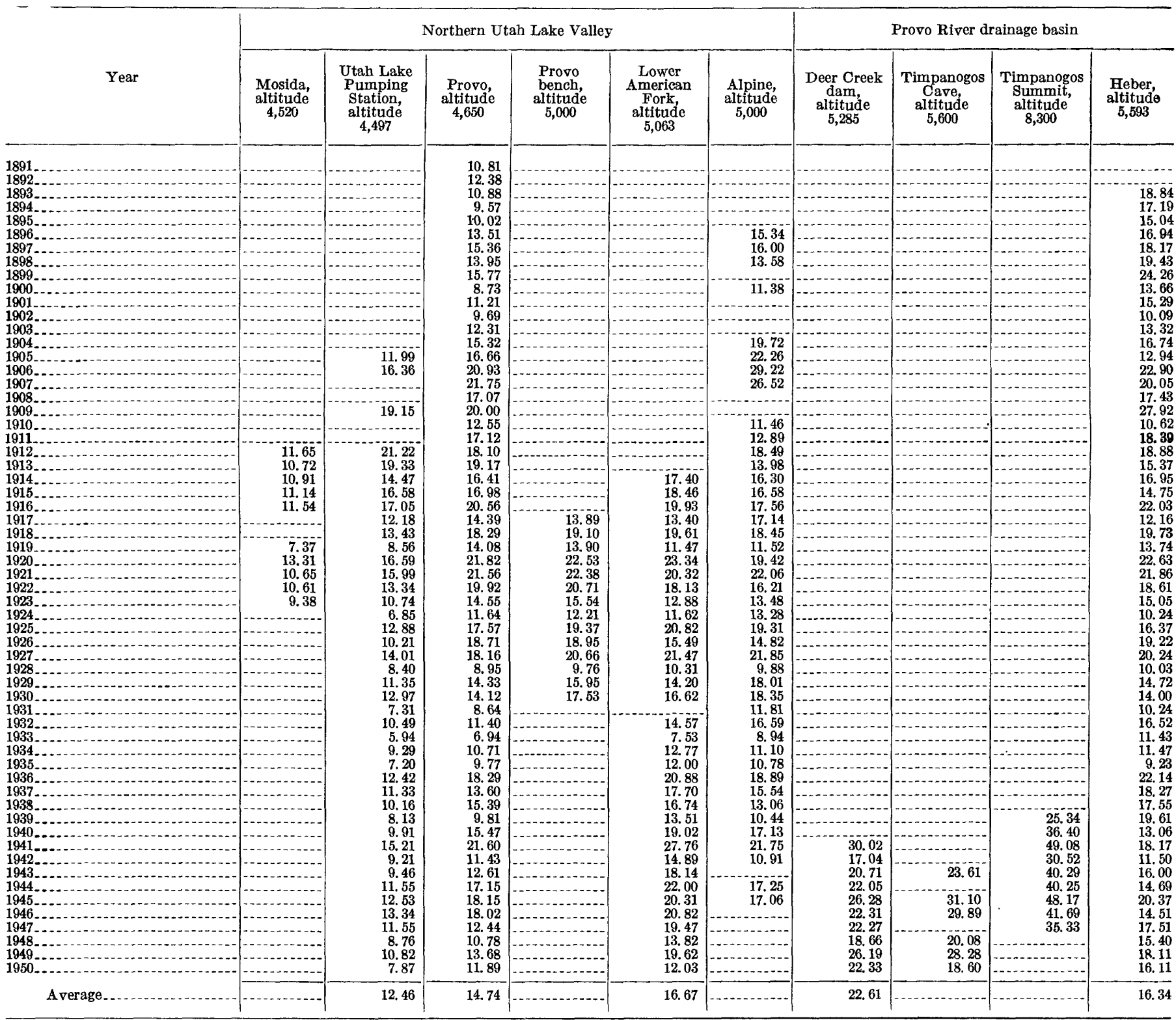

In an average year the frost-free season extends from mid-May to the end of September; it may be slightly longer on valley slopes, particularly on the southwestfacing slopes and terraces. During this $4 \frac{1}{2}$-month growing season the precipitation is generally less than 1 inch per month in the valley; less than one-third of the annual precipitation falls during the growing season (table 2). By contrast, the rate of evaporation has ranged from 5.5 to 13.3 inches per month, and the total evaporation throughout the growing season generally exceeds 40 inches. (See table 3.) Thus the summer climate is sufficiently hot and dry that the amount of evaporation from lakes and reservoirs, as well as from irrigated soils, far exceeds the quantity of water that falls as rain.

The dormant or nongrowing season (October to May) is the period of accumulation of water. These are the months of greatest precipitation and least evaporation. In the valley this is the time for infiltration of water from rain or melting snow, and by early spring the soil-water supplies doubtless reach their maximum for the year. In the mountains of the tributary drainage basin, the winter is a period of accumulation of snow, and as that melts, the reservoirs of the region receive their major increments of storage. The agricultural economy of the valley is founded upon utilizing these 
winter surpluses to overcome the water deficiencies of the growing season.

The annual evaporation from free water surfaces in the valley is generally more than three times as great as the annual precipitation, according to records from a standard Weather Bureau land pan (table 3 ). This pan cannot be operated in the coldest months, and for the months of operation the evaporation has varied from 50.9 inches in 1929 to 73.9 inches in 1934 . In 28 years the average recorded evaporation has exceeded 60 inches a year. The considerable excess of evaporation over precipitation is a condition obviously different from that when Lake Bonneville was formed. Figure 17 shows the recorded fluctuations in the level of Utah Lake as compared to fluctuations in annual rainfall.

Continuous records of precipitation have been obtained for more than half a century at two towns in the drainage basin tributary to north Utah Valley. The rain gage at Provo has been located at a variety of positions during the half century-near the base of the Wasatch Range, in the center of town, and most recently at the airport near the west edge of the town. As a result the records for Provo do not correlate well with records of other stations in Utah Valley and adjacent areas. The gage at Heber, on the other hand, has remained at substantially the same location for 55 years, and an excellent record has been kept by John Crook and his descendants through three generations.
Statistical analysis of the Heber precipitation record for the 53-year period 1893-1945 shows a slight decrease in precipitation, from a general average of 17.6 inches in the 1890's to 16.0 inches in the early 1940's. The average annual precipitation for the 53 -year period is 16.53 inches.

The cumulative departure from average precipitation is of significant value in comparing precipitation

TABLE 2.-Average monthly and annual precipitation at weather stations in or near northern Utah Valley

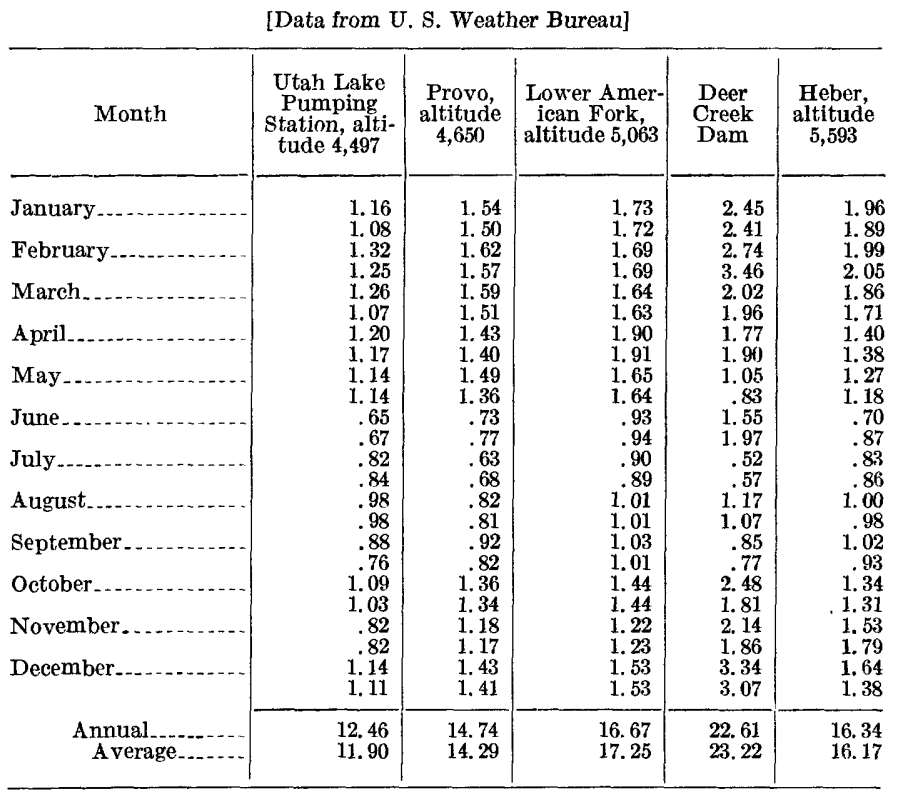

TABLE 3.-Average evaporation (in inches) from Utah Lake near Lehi, Utah County, altitude 4,497 feet

[Data from U. S. Weather Bureau]

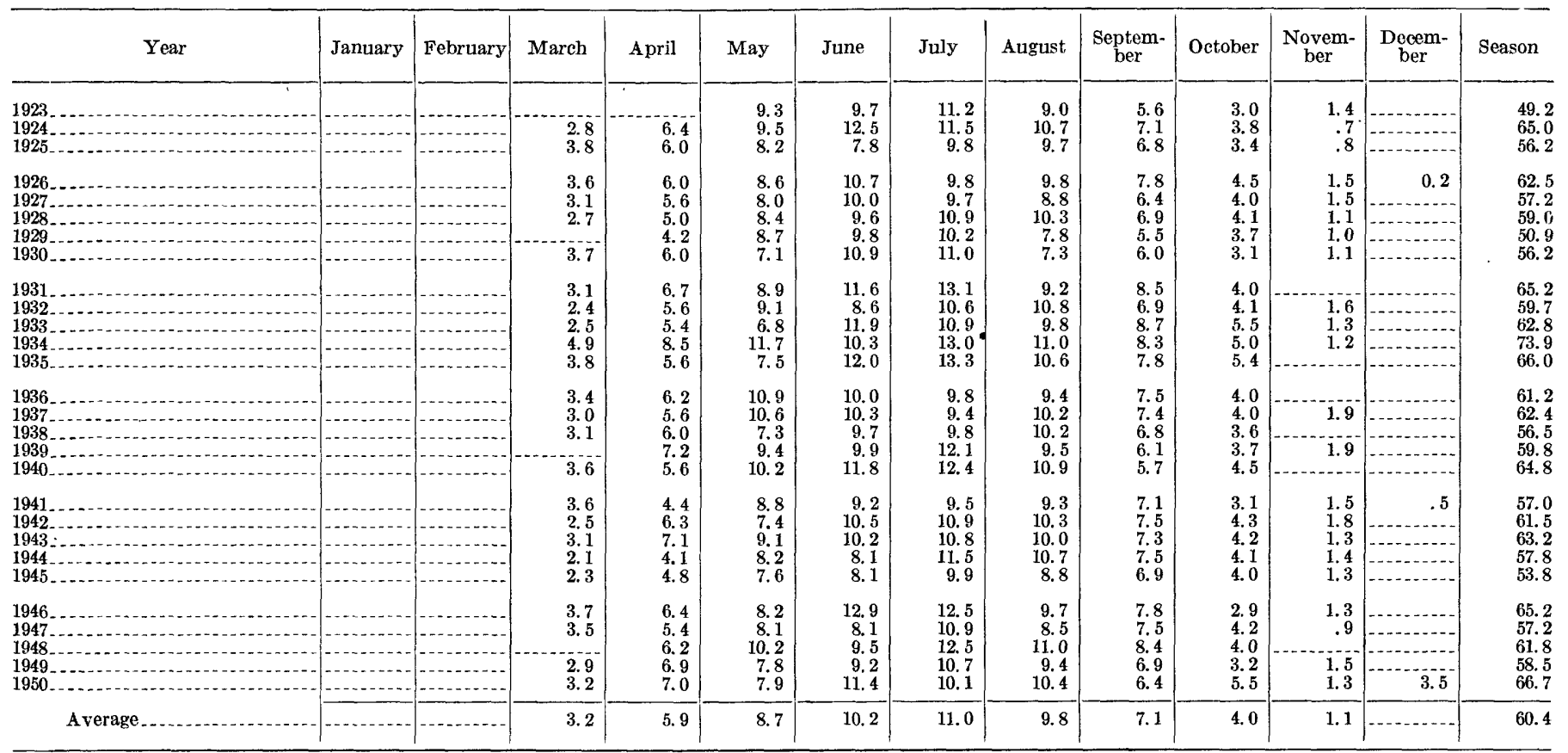


with reservoir storage, whether on the surface or underground. If the reservoir storage is directly correlative with regional precipitation, it will increase during a series of years where precipitation is greater than average and will decline during drought years. A graph of cumulative deviation also shows a rising trend during wet cycles, a horizontal trend in a series of normal years, and a declining trend in drought cycles. Such a graph, based on the precipitation at Heber, shows a close correlation with the fluctuations of stage in Utah Lake (fig. 17).

\section{GENERAL GEOLOGY}

By Charles B. Hunt

\section{STRATIGRAPHY}

Most of the northern Utah Valley floor is composed of sedimentary deposits that were laid down in the Pleistocene Lake Bonneville. Interbedded with these lake deposits is outwash from glacial moraines in the Wasatch Range and overlying the lake beds are recent fluviatile deposits. Beneath the Lake Bonneville group are several hundred feet of unconsolidated fanglomerate and interbedded lake deposits; which rest on late Tertiary water-laid volcanic tuffs, muds, and agglomerates.

In the mountains adjoining the valley, especially along the north side in the Traverse Mountains, is a series of porphyritic lavas, perhaps of mid-Tertiary age. At the northeast corner of the valley is a granitic mountain formed by the Little Cottonwood stock probably during the Tertiary. Pre-Cambrian, Paleozoic, and Mesozoic sedimentary rocks occupy most of the drainage basins of streams flowing to the valley from the Wasatch Range. Some of the valleys contain glacial deposits, but only Alpine Canyon was glaciated all the way to the mountain front. The Pennsylvanian and Permian(?) Oquirrh formation comprises most of the Traverse Mountains and most of the mountains west of the valley.

The rocks in the mountains were the source from which the sediments in the valley were derived.

\section{SOURCE ROCKS IN ADJOINING MOUN'TAINS PRE-CAMBRIAN, PALEOZOIC, AND MESOZOIC ROCKS}

Pre-Cambrian, Paleozoic, and Mesozoic rocks in the Wasatch Range east of Utah Valley have been described by Baker (1947). An accompanying section summarizes his description of these source rocks.

Probably the total amount of valley sediments derived from each of these formations is roughly proportional to the thickness of the formation, except for the pre-Cambrian which is restricted to small areas at the foot of the mountains east of Provo and in the headwaters of American Fork River.
Generalized section of Paleozoic and Mesozoic rocks in theWasatch Range adjoining Utah Valley

[Generalized from Baker, 1947]

\begin{tabular}{|c|c|c|}
\hline 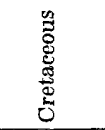 & Price River formation & $\begin{array}{l}\text { Largely conglomerate containing quartz- } \\
\text { ite and limestone boulders. }\end{array}$ \\
\hline \multirow{4}{*}{ 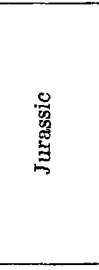 } & Morrison formation. . & $\begin{array}{l}\text { Mostly variegated shale with some } \\
\text { lenticular beds of sandstone and con- } \\
\text { glomerate; } 1,200 \text { feet thick. }\end{array}$ \\
\hline & Curtis formation... & $\begin{array}{l}\text { Shale, mudstone, and sandstone; glau- } \\
\text { conitic(?); 500 feet thick. }\end{array}$ \\
\hline & Entrada sandstone... & $\begin{array}{l}\text { Easily eroded, tan, silty sandstone; } \\
1,250 \text { feet thick. }\end{array}$ \\
\hline & Twin Creek formation.. & $\begin{array}{l}\text { Dense, thin-bedded limestone overlain } \\
\text { by shale; } 1,100 \text { feet thick. }\end{array}$ \\
\hline 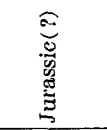 & Nugget sandstone.. & $\begin{array}{l}\text { Massive, firm, tan sandstone; } 1,450 \text { feet } \\
\text { thick. }\end{array}$ \\
\hline \multirow[b]{2}{*}{ 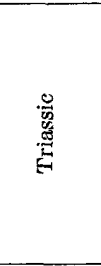 } & Chinle formation... & $\begin{array}{l}\text { Sandstone and variegated silty shale. } \\
\text { Upper part of Ankareh formation as } \\
\text { used by some authors; } 675 \text { feet thick. }\end{array}$ \\
\hline & Moenkopi formation... & $\begin{array}{l}\text { Mostly red platy sandstone, consider- } \\
\text { able red shale, some limestone; } 2,300 \\
\text { feet thick. Some authors combine } \\
\text { the upper } 800 \text { feet with the Chinle } \\
\text { and refor to it as Ankareh; } 1,300 \text { feet } \\
\text { of beds below this commonly is } \\
\text { referred to Thaynes; basal 150-200 } \\
\text { feet referred to Woodside. }\end{array}$ \\
\hline م & Park City formation. & $\begin{array}{l}\text { Mostly limestone, some black shale and } \\
\text { thin beds of phosphate, some sand- } \\
\text { stone; } 2,000 \text { feet thick. }\end{array}$ \\
\hline \multirow{2}{*}{ 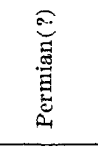 } & Diamond Creek sandstone... & $\begin{array}{l}\text { Mostly coarse-grained sandstone; } 850 \\
\text { feet thick. }\end{array}$ \\
\hline & Kirkman limestone & Limestone; 1,600 feet thick. \\
\hline 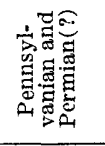 & Oquirrh formation..... & $\begin{array}{l}\text { Mostly quartzitic sandstone, lower few } \\
\text { thousand feet contains considerable } \\
\text { limestone; total thickness about } \\
18,000 \text { feet. }\end{array}$ \\
\hline 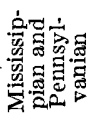 & Manning Canyon shale..... & $\begin{array}{l}\text { Mostly black to dark-brown shale; } \\
\text { some interbedded limestone and con- } \\
\text { glomeratic sandstone; } 1,600 \text { feet } \\
\text { thick. }\end{array}$ \\
\hline 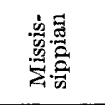 & $\begin{array}{l}\text { Madison, Deseret, Humbug, } \\
\text { and Great Blue lime- } \\
\text { stones. }\end{array}$ & $\begin{array}{l}\text { Practically all limestone; } 4,600 \text { feet } \\
\text { thick. }\end{array}$ \\
\hline 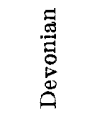 & Jefferson(?) dolomite.... & $\begin{array}{l}\text { Dolomite, some limestone; } 250 \text { feet } \\
\text { thick. }\end{array}$ \\
\hline \multirow{4}{*}{ 苞 } & Lynch dolomite............... & 150 feet thick. \\
\hline & Maxfield limestone.... & 600 feet thick. \\
\hline & Ophir shale. & $\begin{array}{l}\text { Phyllitic, olive-green shale; sorae lime } \\
\text { stone and quartzite; } 250 \text { feet thick. }\end{array}$ \\
\hline & Tintic quartzite.- & $\begin{array}{l}\text { Hard quartzite; some conglomerate at } \\
\text { base; 1,200 feet thick. }\end{array}$ \\
\hline 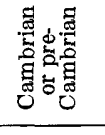 & Tillite..... & $\begin{array}{l}\text { Well-rounded boulders of dolomite } \\
\text { and quartzite as much as } 1 \text { foot in } \\
\text { diameter, in firm coarse-grained ma- } \\
\text { trix that has slatey cleavage; } 150 \text { feet } \\
\text { thick. }\end{array}$ \\
\hline 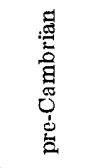 & Phyllite... & $\begin{array}{l}\text { A few hundred feet exposed, princi- } \\
\text { pally at base of mountain east of } \\
\text { Provo; some in headwaters of Amer- } \\
\text { ican Fork River. }\end{array}$ \\
\hline
\end{tabular}


The Pennsylvanian formations comprise most of the Traverse Mountains along the north side of the valley and the Lake Mountains west of the valley.

TERTIARY(?) ROCKS

LITTLE COTTONWOOD STOCK

Little Cottonwood stock, a quartz monzonite intrusive into Paleozoic rocks (Calkins and Butler, 1943, pp. 38-40), occupies somewhat more than half the drainage basin of Dry Creek and extends into the headwaters of American Fork River. In describing gravel and other sediments of Utah Valley derived from this source, the materials will be referred to as granitic.

LAVAS AND WATER-LAID VOLCANICS

Rather glassy and distinctly porphyritic lavas crop out in the Traverse Mountains and gravels derived from these lavas are abundant in the younger valley deposits in the north part of the valley. Within northern Utah Valley there is a single outcrop of the old lavas, in the $\mathrm{E}^{1} \frac{1}{2}$ sec. 2 , T. 5 S., R. $1 \mathrm{~W}$. Similar lavas and some basalts crop out extensively along the Provo River east of the Wasatch Range, but the gravels from these eruptives comprise only 2 or 3 percent of the sediment brought into Utah Valley by Provo River.

On the east slope of the Wasatch are some waterlaid volcanics, mostly reworked tuffs. Their present areal extent is not great but their presence would suggest that the mountains were once extensively covered with these easily eroded materials, and if so, they probably contributed to sedimentation in the valley far more than their thickness or present areal extent would suggest.

These lavas and water-laid volcanic deposits almost certainly are of Tertiary age, and they may represent intermittent eruptions spanning a considerable part of Tertiary time.

\section{QUATERNARY DEPOSITS IN THE MOUNTAINS}

GLACIAL DEPOSITS

Extensive moraines and other glacial deposits have accumulated in the drainage basins of Provo River, American Fork River, and Dry Creek. Along Dry Creek, glaciers descended at least twice to the very edge of Utah Valley. A conspicuous moraine containing fresh, unweathered granitic debris extends from high on the mountain to the mouth of Alpine Canyon. A less conspicuous and older moraine that has been deeply weathered extends half a mile farther into the valley.

ALLUVIAL AND OTHER SURFICIAL DEPOSITS

Some of the valleys in the mountains contain fairly deep alluvial fill. Provo River at Heber, immediately east of the Wasatch Range, is in a wide valley contain- ing extensive and deep fill, but the deposit is not well enough known as yet to appraise its effect on sedimentation in Utah Valley.

In many of the more rugged sections of the mountains, broken rock has accumulated in large talus cones at the foot of cliffs or steep rocky slopes. At other places that are only slightly less steep and rocky, hillside wash is mixed with the broken rock in steep colluvial cones. At still other places there is preserved an old topographic surface that consists of comparatively rounded landforms and presents a decidedly more mature aspect than do the taluslittered rocky cliffs so conspicuous along the main canyons and in the glaciated areas. Mantling this old surface are remnants of an old and deep soil. (See p. 44.) The old surface and the soil on it are being dissected today, and it is evident that both were formerly much more extensive. Indeed, the whole range probably once had a mature surface and deep soil like those of the remnants. If so, erosion of the old deep soil could account for the excessive proportion of fine-grained sediments that are found in some of the deposits of Utah Valley, notably in the Alpine formation.

The Traverse Mountains, whose valleys have only small drainage basins, is composed almost entirely of smoothly rounded hills that are mantled by a deep and old soil. The Lake Mountains appear to be more like the Wasatch in that they have small remnants of the old surface and soil preserved in the midst of the rocky and youthful landforms that are being developed by the present erosion cycle.

\section{SOME REIATIONSHIPS BETWEEN THE SOURCE ROCKS} AND VALLEY SEDIMENTS

The areal distribution of the source rocks has been a major factor controlling variations in composition of the sediments in different parts of the valley.

The sediments being brought into the valley by Provo River contain more quartzite than limestone, because of the wide extent of the tremendously thick Pennsylvanian series along the river where it crosses the Wasatch Range. Mixed with these sediments is a small percentage of lavas derived from the volcanics above Heber. The sediments being brought into the valley by American Fork River contain about an equal proportion of limestone and quartzite because the pre-Pennsylvanian formations there are more extensive than along Provo River. In addition, sediments of the American Fork River contain a small percentage of granitic material, for the headwaters of the river drain the southeast side of the Little Cottonwood stock. Dry Creek roughly follows the contact between the granite of the Little Cottonwood stock and the pre-Pennsylvanian limestone and quartz- 
ite on the south side of the stock; sediments being brought into the valley by Dry Creek are 30 or 40 percent granitic and the remainder is quartzite or limestone.

The conditions of drainage, however, varied a good deal during Late Tertiary and Quaternary time. During late Teritary time most or all of the tributary mountain area must have been covered with volcanic ash. At several stages during the Pleistocene history of the mountains extensive glacial deposits were formed; at other stages fluviatile erosion was as dominant as it is now, and at still other stages the rate of weathering so exceeded the rate of erosion that deep soil formed over the source rocks. There were times in the past, therefore, when the source rocks on the mountains were quite different than they are today and these differences are recorded in the types of sediment that have been deposited in the valley at different times.

\section{DEPOSITS IN UTAF VAINEY}

SALT LAKE FORMATION (TERTIARY)

The oldest rocks recognized thus far in the valley are a well-stratified series of water-laid volcanic deposits. Similar rocks are widespread in northwestern Utah and have been referred to as the Salt Lake formation. (Wilmarth, 1938, p. 1897.) They are thought to be of late Tertiary (Pliocene?) age.

Although the Salt Lake formation is rather extensively exposed in several of the valleys of northwestern Utah and similar beds are found in the Wasatch Range east of Mount Timpanogos, these beds have not been systematically studied and mapped. In Utah Valley the formation is exposed only in a very small area in the Jordan Narrows, at the extreme northwest corner of the valley (pl. 1). Mapping other basins having more extensive outcrops of the formation no doubt will reveal its habit and will permit more satisfactory interpretation of its extent, thickness, and potential importance in Utah Valley than can be made now.

In the Jordan Narrows about 200 feet of beds belonging to the Salt Lake formation are exposed. The lower 100 feet of the exposed beds are white or very light gray. Near the base is a 3 -foot bed of friable tuff, composed largely of glass shards but including a few tiny crystals of feldspar and quartz. The fresh rock contains little or no carbonate. Overlying this tuff is a series of alternating dark-gray silt and white or light-gray, firm, ledge-forming beds that probably are cemented, reworked tuffs. The individual beds range from 2 to 20 feet in thickness; included wth them are a few, very thin, clay partings. The firm ledgeforming beds contain poorly preserved molluscan re- mains that Dr. T. C. Yen of the U. S. National Museum identified as belonging to the snail genus Gyraulus. These beds perhaps are reworked tuffs that have been cemented with lime. They effervesce strongly in acid and yield strong calcium precipitates. Under the microscope can be seen an occasional glass shard.

These light-colored beds are overlain unconformably by a series of buff beds with a basal conglomerate which dips $5^{\circ}$ less than the underlying light-colored finetextured beds. The contact is channeled and some of the channels are 3 feet deep. About 15 feet of the overlying beds are cut off northward.

The beds above the unconformity are buff. The basal conglomerate is about 15 feet thick and contains lava and quartzite boulders as much as 3 feet in diameter. Above this is 50 feet of moderately consolidated buff sand and silt, which apparently is reworked erystal tuff partly cemented by lime carbonate.

These buff beds are cut off southward at a fault, on the south side of which is at least 50 feet of conglomerate that may also be part of the Salt Lake formation.

The deepest penetration into the Salt Lake formation by wells is believed to have been by a well drilled at Cutler in the center of sec. 5, T. 5 S., R. 1 E. The driller's $\log$ and geologic interpretation for this well are tabulated below.

Driller's log of Union Pacific $\underset{\text { Utah }}{R R}$ well $($ D-5-1) 5caa-2 at Cutler.

Eight-inch well drilled 690 feet deep in December 1915 . Located in the NE14NE1/4SW1/4 sec. 5, T. 5 S., R. 1 E.; altitude of land surface about 4,609 feet above sea level. Well plugged and abandoned prior to 1945 . $(W)=$ Water-bearing.

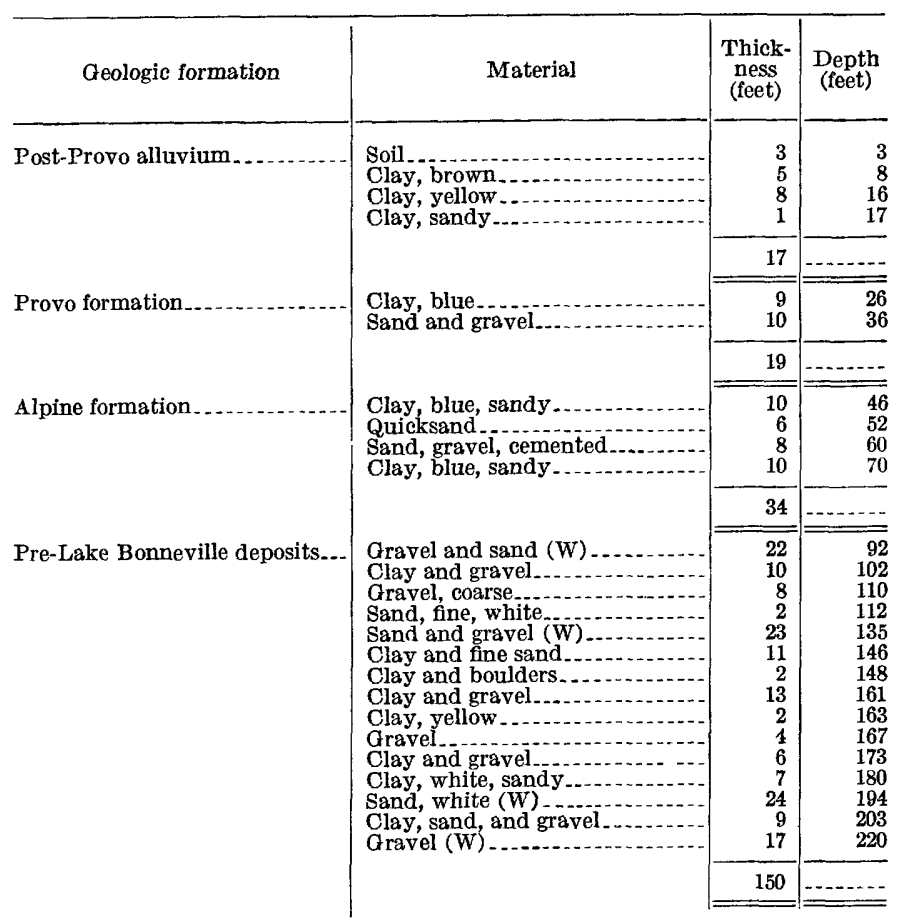


Driller's log of Union Pacific $R R$ well (D-5-1) 5caa-2 at Cutler, Utah-Continued

\begin{tabular}{|c|c|c|c|}
\hline Geologic formation & Material & $\begin{array}{l}\text { Thick- } \\
\text { ness } \\
\text { (feet) }\end{array}$ & $\begin{array}{l}\text { Depth } \\
\text { (feet) }\end{array}$ \\
\hline \multirow[t]{3}{*}{ Salt Lake formation (Pliocene ?) } & 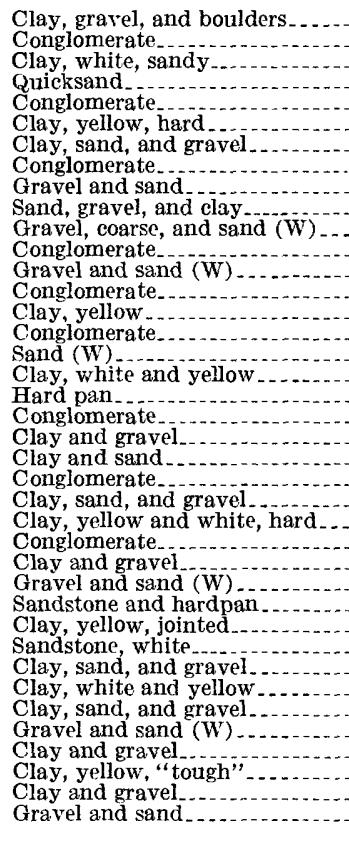 & $\begin{array}{r}4 \\
2 \\
4 \\
3 \\
7 \\
3 \\
13 \\
17 \\
3 \\
10 \\
5 \\
15 \\
3 \\
33 \\
10 \\
11 \\
3 \\
10 \\
2 \\
6 \\
3 \\
14 \\
14 \\
6 \\
44 \\
8 \\
13 \\
7 \\
3 \\
35 \\
3 \\
18 \\
26 \\
44 \\
5 \\
6 \\
27 \\
25 \\
3\end{array}$ & $\begin{array}{l}224 \\
226 \\
230 \\
233 \\
240 \\
243 \\
256 \\
273 \\
276 \\
286 \\
291 \\
306 \\
309 \\
342 \\
352 \\
363 \\
366 \\
376 \\
378 \\
384 \\
387 \\
401 \\
415 \\
421 \\
445 \\
473 \\
486 \\
493 \\
496 \\
531 \\
536 \\
554 \\
580 \\
624 \\
629 \\
635 \\
662 \\
687 \\
690\end{array}$ \\
\hline & & 470 & \\
\hline & "Bedrock, apparently.". & & \\
\hline
\end{tabular}

No cuttings from this well were available. Judging from the driller's log the top of the formation is about 220 feet deep (pl. 4 , sec. $F-F^{\prime}$ ).

This well and others farther south, together with the outcrop of the formation in Jordan Narrows, indicate that the surface of the Salt Lake formation slopes southeastward under the valley. In the Narrows the top of the formation is at an altitude of about 4,600 feet; at the Cutler well its altitude is about 4,400 feet; at the well in sec. 10 , T. 5 S., R. 1 E., its altitude is no higher than 4,275 feet; at the well in sec. 26, T. 5 S., R. 1 W., its altitude is below 4,160 feet; and at Geneva the altitude of the uppermost Tertiary beds is considered to be about 3,750 feet.

To the extent that the Salt Lake formation resembles the late Tertiary water-laid volcanic beds in other parts of the Basin and Range province, the formation could be expected to embrace several units separated by angular unconformities and to span a considerable period of time.

The lava and quartzite boulders in the conglomerate at Jordan Narrows are like the lava and quartzite in the adjoining hills of the Traverse Mountains and evidently were derived from them. This is evidence that Utah Valley had already started to develop as a structural depression when the Salt Lake formation was deposited.
By analogy with the similar valleys along the lower part of the Colorado River, where the late Tertiary history is better revealed than in Utah Valley, it is inferred that Utah Valley was a well-developed structural basin and site of sedimentation in late Tertiary time. If so, the Salt Lake formation must include beds of ash that fell in the basin, as well as other beds reworked from the ash that must have fallen on the adjoining and rising mountains.

Volcanic detritus, characteristic of the Salt Lake formation exposed at Jordan Narrows, was not found in the cuttings from the deep well of the Geneva Steel Co. (See fig. 5.) However, in other localities (Thomas 1946, pp. 116-118; Williams, 1948, pp. 1121-1164). Tertiary strata of nonvolcanic debris overlying tuffs and breccias have been included within the Salt Lake formation. The sediments penetrated in the lower 340 feet of the Geneva deep well are regarded as Tertiary. Data obtained from the well cuttings, however, are inadequate to identify the materials as part of the Salt Lake formation as described in various areas.

\section{PRE-LAKE BONNEVILLE DEPOSITS (PLEISTOCENE)}

Pleistocene pre-Lake Bonneville deposits under Utah Valley are several hundred feet thick. The deposits have been penetrated by several wells; one drilled by the Geneva Steel Co. is more than 800 feet deep. The only exposures of the pre-Lake Bonneville deposits are the huge alluvial fans that form a fringe around the valley and that spread apronwise from the foot of the adjoining mountains.

Exposed deposits.-Gilbert recognized the fans as older than Lake Bonneville (Gilbert, 1890, pp. 220222) because the lake has impressed its shore mark on those fans that rise above the high-water mark of the lake. In addition to this evidence, at many places in Utah Valley the Lake Bonneville group is exposed where it overlaps onto the fan deposits.

All the fans are alike in being composed of poorly sorted materials, angular boulders, cobbles, and gravel in a sand and silt matrix; but the fans differ from one another in the kinds of gravel they contain, depending on the source rocks in the immediately adjoining mountains. The fan materials are in large part poorly consolidated but in this report they are referred to as fanglomerate.

The pre-Lake Bonneville fans along the west side of the valley and those along the south side of the Traverse Mountains were derived largely from the quartzitic part of the Oquirrh formation and are composed mostly of quartzitic material. The fans along the south side of the Traverse Mountains also include some material derived from the porphyritic and glassy 
lavas in the range. Pre-Lake Bonneville fans east of Alpine and east of Provo contain limestone and quartzitic material in about equal proportions. The fans east of Alpine were derived from the older Paleozoic limestones and Cambrian quartzite. All the Paleozoic formations, including the Oquirrh, contributed material to the fans east of Provo. The fans between American Fork Canyon and Provo River, on the other hand, were derived very largely from Paleozoic limestone formations.

The fans along the foot of the Wasatch Range and along the west side of the valley contain abundant cobbles and boulders, many a foot or more in diameter; whereas the fans at the south side of the Traverse Mountains contain fine gravels, probably because the Traverse Mountains are lower than the Wasatch and have not been deeply dissected.

The sand mixed with the gravelly or bouldery materials in the fans consists of subangular grains, in contrast to the lacustrine sands which are rounded or subrounded (fig. 4).

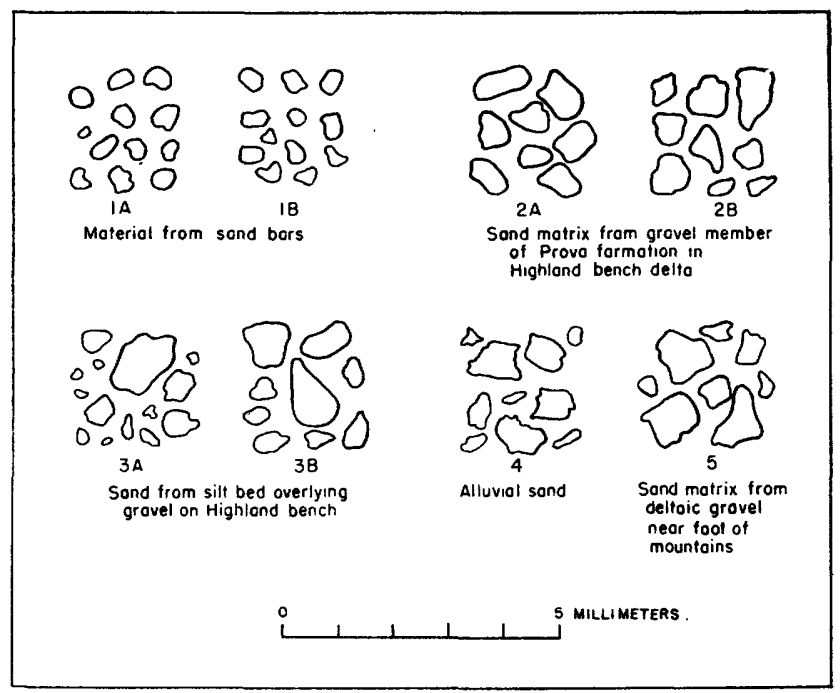

FlGURE 4.-Sketches to illustrate some variations in sizing and rounding of sand grains in different kinds of deposits in Utah Valley.

The surface of the fans and the obscure bedding in them slope several hundred feet per mile toward the basin. Commonly the fan form is perfectly preserved, but at several places the fan deposits have been faulted and the upfaulted segments are being eroded. The deposits northwest of Alpine have been rather maturely dissected into rounded hills resembling those formed on the bedrock in the Traverse Mountains. Mantling these hills of fanglomerate is deep soil (p. 44). Some of the fans along the foot of the Wasatch Range and also locally along the foot of the Lake Mountains have been faulted; the upfaulted segments are being dissected. These also are mantled by deep soil and at several places the old soil is overlapped by the Lake Bonneville deposits. The fans therefore were deeply weathered and covered by a deep soil prior to or during the early stages of Lake Bonneville. (See fig. 10.)

Most of the fans are covered with a recent mantle of boulders and finer sediment, but these Recent deposits, which have been washed from the mountains since the time of Lake Bonneville, constitute only a thin layer on the main body of the fans. Gilbert recognized this fact though he did not stress it in his report. An entry in his notes dated August 12, 1872, states, "The gravel slopes made since the lake are a small item compared with those made before." Because of the comparative insignificance of the post-lake deposits they are incompletely shown on the geological map (pl. 1).

At some places, notably at the west end of the Traverse Mountains, the pre-Lake Bonneville fluvial deposits were reworked slightly by the waves and currents of Lake Bonneville. The reworking is revealed by small wave-cut terraces or by small embankment bars. Properly, such reworked material should have been mapped as part of the lake formations but this was not feasible except where the reworking was sufficient to produce a deposit that differs in texture, composition, or sorting from the original fluvial deposit.

These pre-Lake Bonneville fluvial deposits are exposed today only near their source, the foot of the mountains. Basinward they are concealed by younger sediments but numerous wells in the interior of the valley furnish considerable information about the buried deposits and suggest that parts of them are of lacustrine rather than fluviatile origin.

Concealed deposits.-Wells drilled in the valley show that the top of the pre-Lake Bonneville deposits is commonly from 75 to 100 feet below the surface. At the Geneva Steel plant, where the best record was obtained (A-16225), the top of the pre-Lake Bonneville deposits is 105 feet below the surface and is marked by a peat layer that clearly records the subaerial conditions prevailing before Lake Bonneville came into existence.

Figure 5 shows the log of this well. The well penetrated several thick deposits of clay that apparently represent glacial lakes; their thickness is less than the clay deposits of the Lake Bonneville group so it could be inferred that the more ancient lakes were shorterlived. The gravel deposits separating these presumed glacial-lake clay deposits are probably largely of fluvial origin and probably represent interglacial stages. It should be noted, however, that in this well there are no means for distinguishing fluvial from deltaic gravel deposits, and some of the gravel, especially between about 240 and 420 feet, very possibly was deposited as deltas in glacial lakes. 


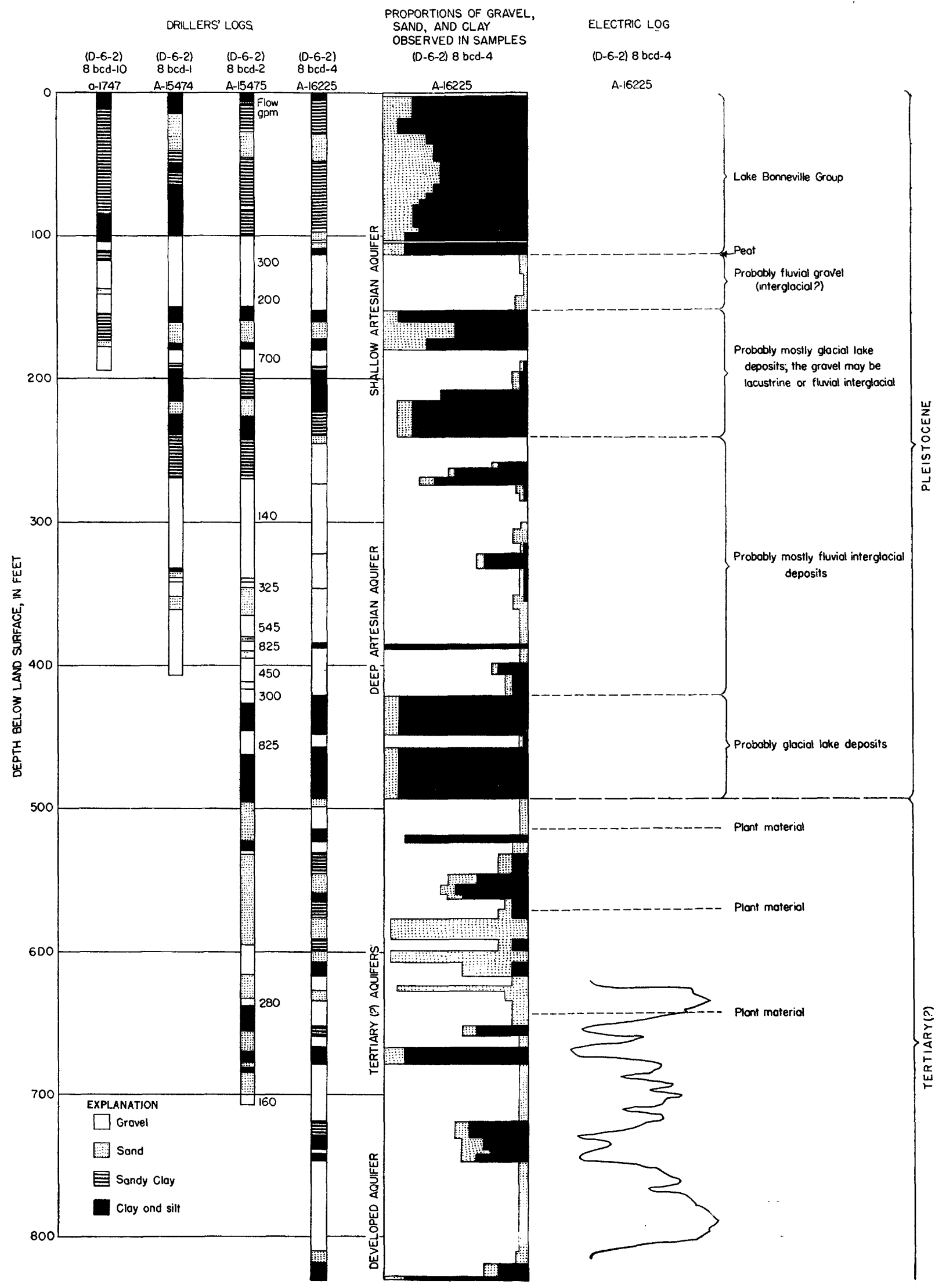

FigURE 5. - Logs of wells drilled at Geneva Steel plant. 
These gravel beds constitute important aquifers which yield water. under artesian pressure in the lower parts of Utah Valley. Most wells obtain water from the uppermost pre-Lake Bonneville gravel, the overlying Lake Bonneville group forming the confining layer, but many wells penetrate the second thick bed of clay and obtain water with higher pressure head from deeper gravels. In many places the pre-Lake Bonneville gravels are highly permeable, and Utah Valley consequently has some of the most productive flowing wells in the State. The geology of these deposits, particularly as it affects ground-water hydrology, is discussed further on pages 60-91. Geologic sections based on well logs (pl. 4) show the principal aquifers topped by wells in north Utah Valley.

\section{LAKE BONNEVHLE GROUP}

Lake Bonneville, the last of the great Pleistocene lakes that flooded Utah Valley, covered almost 20,000 square miles in western Utah and had a maximum deptb of about 1,000 feet (fig. 1). Utah Valley was a bay along the eastern side of the lake.

The deposits that were laid down in Lake Bonneville in northern Utah Valley can be divided into three formations, each of which represents a different stage in the history of the old lake. These are the Alpine, Bonneville, and Provo formations, and they correspond respectively to what Gilbert (1890, pp. 90-152) referred to as the Intermediate, Bonneville, and Provo stages of the lake. Around Great Salt Lake, Gilbert recognized a fourth stage that he named the Stansbury. This is the youngest stage and represents a lake level lower than the other three and approximately at the level of Utah Lake. The sediment in the bottom of Utah Lake therefore includes material deposited during the Stansbury stage and more recent time.

Since Lake Bonneville time there has been little erosion within the valley, and the younger of the lake deposits still preserve the constructional forms they had when they were deposited. Moreover, since Lake Bonneville time the climate has become drier; the soilforming processes are feeble and soil profiles on the Lake Bonneville group are only weakly developed except very locally where there is or has been an excess of surface water.

ALPINE FORMATION

Oldest of the Lake Bonneville group is the Alpine formation. Gilbert used the name Intermediate to refer to the lake stage represented by these deposits, the name having been derived from the fact that around the sides of the valley these deposits are exposed at levels intermediate in altitude between the Provo and Bonneville levels (Gilbert, 1890, pp. 135-154). The name Intermediate, however, is unsatisfactory because the deposits of that stage underlie the other Lake Bonneville formations. For this reason the name Alpine formation is introduced in this report instead of the old name. The formation is named for the town, around which there are numerous typical exposures.

Typically, the Alpine formation contains a high proportion of fine-textured sediment, mostly silt. (See fig. 13.) Sorting is excellent; the bedding is very distinct and in the finer-grained sediments individual beds commonly are only a fraction of an inch in thickness. The upper part of the formation is light gray but it is horizontally striped by thin beds that are rusty colored; the lower part of the formation is somber gray.

In the interior of the valley the formation thickens southward from about 50 feet in the vicinity of Lehi to about 100 feet near Provo. In the interior of the valley the formation is clayey although beds of gravel and sand are encountered in some wells.

Around the sides of the valley the Alpine overlaps onto the pre-Lake Bonneville alluvial fans, and these overlapping beds are nearly horizontal where they abut against the steeply sloping surface of the alluvial fans or other pre-Lake Bonneville deposits. The present erosion surface cuts off the basinward parts of the beds which, if projected, would extend well above the present valley surface. Probably the Alpine formation thinned rapidly basinward, but later erosion has destroyed the evidence for that thinning.

Although the Alpine formation is in large part fine-textured even near the steep front of the mountains, it does contain considerable sand and some gravel. As would be expected, these coarse clastic deposits are thickest near the mouths of the canyons draining the mountains. On the basis of prevailing texture the formation is divided into three membersone composed largely of gravel, one largely of sand, and one largely of silt and (or) clay. These members are given lithologic names but they are not homogeneous units; the silt member for example, contains thin layers of clay, sand, and even some gravel. Variations like this are seen in most outcrops.

Gravel member.-The gravel member of the Alpine formation is exposed at the mouth of American Fork Canyon, along Dry Creek at Alpine, and near the Jordan Narrows. In addition some wells in the valley encountered gravel in beds assigned to the Alpine formation.

At the mouth of American Fork Canyon the gravel member crops out in the steep slope along the west side of the highest-level lake benches on each side of the stream. The north side of the southern bench and the south side of the northern bench are entirely gravel. No means were found for distinguishing be- 
tween the gravel of the Alpine formation and the overlying gravel of the Bonneville formation. Presumably the lower hundred feet or so is Alpine.

Northward and southward from the stream, however, the gravel of the Alpine formation grades laterally into silt and sand, so the formation there becomes distinctive from the overlying Bonneville formation. Half a mile north of the stream the gravel is in two beds, each only a few feet thick and separated by many feet of fine-textured sediments; three-quarters of a mile south of the stream the gravel is in three thin beds. These are tongues of gravel that thin northward and southward and grade into finer sediments.

The gravel is typical of that transported by American Fork River in that it is composed very largely of limestone and quartzite in roughly equal proportions. The size of the gravels diminishes considerably within a short distance north and south from the stream; near the stream many cobbles are 6 inches in diameter, but half a mile away the common large ones are only about 2 inches in diameter. On the map (pl. 1) these gravel tongues are shown grading laterally into the silt member of the Alpine but, as might be expected, this part of the silt member contains considerable sand.

Half a mile west of the town of Alpine the gravel member is about 50 feet thick and includes volcanic and quartzitic material derived from the Traverse Mountains and granitic material from the Little Cottonwood stock. Limestone is not abundant. The gravel deposits north and northeast of town are similar except that they include considerable limestone. The gravel west of town thins westward and within about a mile its place is taken by sandy beds, evidently the result of lateral gradation. These gravels were brought into the old lake by Dry Creek and its tributaries.

At least 40 feet of the gravel member of the Alpine formation is exposed on the upstream side of the Jordan Narrows. This gravel is in beds a few inches to a few feet thick separated by a few to several feet of sand and silt, but even the silty beds contain some pebbles. The gravels are not coarse; most of the pebbles are one-half inch in diameter. The pebbles are very well rounded. Most are quartzite, though some are limestone, and probably were derived from the Traverse Mountains. With them is an occasional pebble of granite evidently brought from the vicinity of Dry Creek. Interbedded with the gravel is finely laminated sand or silt. The bedding in some of these fine-grained sediments is highly contorted but the contorted bedding ends upward and downward at plane bedding surfaces. It is likely that the gravel member at this locality represents an old spit built westward from the Traverse Mountains.
The gravel member probably is present beneath the sand member at the mouth of Frovo Canyon. A mile and a half northwest of the canyon mouth is a bed of gravel that disappears northwestward, perhaps by gradation to sand. Toward the canyon mouth this bed is concealed but in that direction it probably is persistent and perhaps thicker.

Along the mountain front the gravel member of the Alpine formation is found only near the mouths of large canyons. Between the canyon mouths the Alpine is fine grained, locally even clayey. The low proportion of coarse material in the formation, even where it overlaps the steep slopes on the pre-Lake Bonneville alluvial fans, is in striking contrast to the habit of the Bonneville and Provo formations, both of which contain a large proportion of gravel.

There appears to be little gravel in the formation in the interior of the valley although some was encountered in a few wells. Several gravel beds, for example, can be recognized in the logs of the holes drilled to test foundation conditions at the Geneva Steel plant (fig. 6). These beds seem to be lenses elongated in a northwesterly direction. All of them are in the upper half of the formation; the lower half is sand, silt, or clay. Apparently the lenses end westward near the center line of section 8 , for no gravel was encountered in the numerous holes farther west, nor is gravel seen in outcrops in the bluffs at the edge of Utah Lake. Nothing is known about their extent eastward.

Considerable sand and gravel also is reported in the logs of some wells that penetrated the Alpine formation in the vicinity of Lehi and a few miles south of the Geneva Steel plant, in secs. 28 and 34, T. 6 S., R. 2 E.

Sand member.- The sand member of the Alpine formation generally is found near the mouths of the canyons that drain into the valley. In addition, this member underlies the Provo formation at the Geneva Steel plant and at the bluffs facing Utah Lake west of the plant.

The sand member is finely laminated, and contains layers of grit, or even gravel, and layers of silt or clay. At outcrops there is considerable iron stain, mostly along the bedding planes. Sieve analyses by engineers who investigated foundation conditions for the Geneva Steel plant indicate that most of the sand in the Alpine formation at the plant is finer than 1 millimeter in diameter, 50 percent is finer than 0.3 millimeter, and 10 percent is finer than 0.1 millimeter.

The sand member is about 150 feet thick a mile northwest of the mouth of Provo Canyon. However, near the middle of the member are several beds of silt and clay, shown on the map (pl. 1) as a single tongue of the silt and clay member. The sand above and below the silt and clay thins northwestward as the silt and 


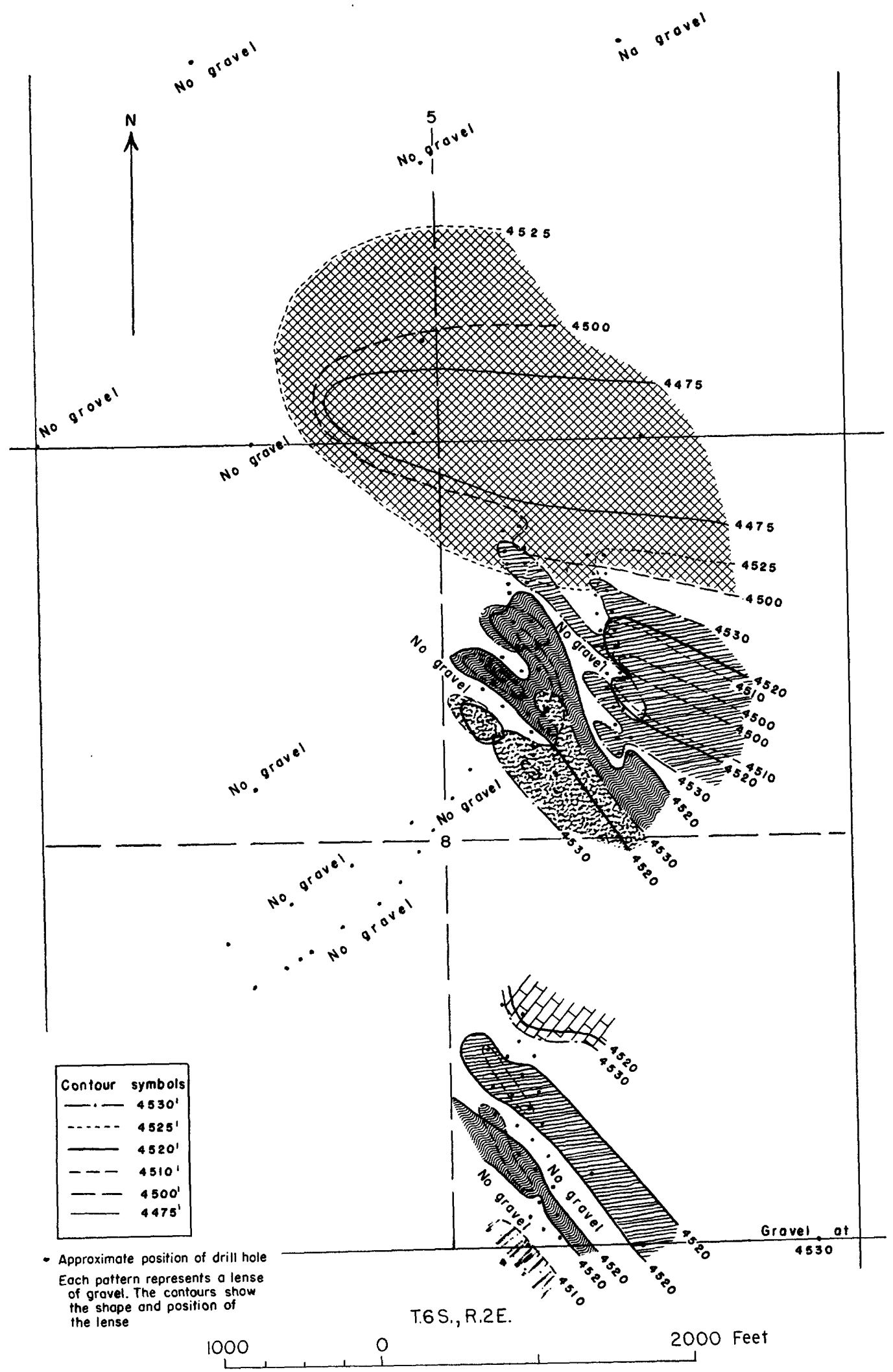
FIGURE 6.-Sketch to illustrate the pattern formed by the gravel beds in the Alpine formation at the Geneva Steel plant. Contours on the edges of the gravel lenses are at 10-foot intervals except on the approximate position by dots. 
clay thicken, presumably because of lateral gradation in facies.

Silt and clay member.-The silt and clay member of the Alpine formation is exposed along the foot of the mountains between the canyon mouths, and it underlies much of the interior of the valley.

The member everywhere is thinly and evenly bedded. Individual beds range from $1 / 8$ to 2 inches in thickness and are composed of clay, silt, sand, and grit in alternating layers, but the finer textures predominate. (See fig. 13.) Streaks of iron oxide along the bedding planes produce rusty-colored outcrops.

In places the laminations are fine enough to be sug. gestive of varves. As many as 40 clay layers separated by 40 layers of silt, sand, or grit have been observed in a section only 60 inches thick.

These finely laminated, fine-textured lake beds overlap steep surfaces on the bouldery, pre-Lake Bonneville alluvial fans. The contact has been examined at many places but it reveals surprisingly little reworking of the fan materials. This condition prevails even at places where the later stages of the lake left conspicuous signs of strong shore current.

Ostracodes, collected from the silt and clay member in an excavation for a bridge abutment where the road west from Lehi crosses the Jordan River, were submitted to Fred M. Swain who has reported the following species:

Candona sp. Abundant fragments.

Limnicythere sp. aff. L. sancti-patricii Brady and Robertson. Rare.

Limnicythere sp. aff. L. inopinata (Baird). Rare.

Swain states that these forms are probably Holarctic, and that Limnicythere inopinata suggests a possible saline environment, but that the evidence against an entirely fresh-water environment is not conclusive.

Inasmuch as Lake Bonneville had not developed an outlet at the time the Alpine formation was deposited, it probably contained at least moderate quantities of salts in solution. There is geochemical data in support of this. (See p. 34.)

Engineers studying foundation conditions at the Geneva Steel plant made some mechanical analyses of stiff silty clay from test holes in the Alpine formation. Seventy percent of the clay is finer than 0.02 millimeter, 45 percent finer than 0.005 millimeter, and 10 percent finer than 0.001 millimeter. Similar analyses of some of the silt beds showed 75 percent finer than 0.075 millimeter, 30 percent finer than 0.02 millimeter, and 10 percent finer than 0.005 millimeter. Mechanical analysis of a sample collected by Sanchez from the silt and clay member south of the Traverse Mountains shows more clay than probably is typical of the member in that part of the valley. His sample, taken from the upper 6 feet, contained the following (Sanchez, 1904, p. 17):

Mechanical analysis of clay, center sec. $27, T .4 S ., R .1 E$. [Sample contained 29.2 percent calcium carbonate.] Percent Sand coarser than $0.10 \mathrm{~mm} \ldots \ldots . .14$ Sand 0.05 to $0.10 \mathrm{~mm}$ Silt 0.005 to $0.05 \mathrm{~mm}$ Clay 0.0001 to $0.005 \mathrm{~mm}$

Chemical analyses for soluble salts in samples from the silt and clay member indicate that it contains on the average about one-half percent of such salts. The quantity appears to increase shoreward. (See table 13.)

BONNEVILLE FORMATION

The Bonneville formation includes those deposits that accumulated in the lake during its highest stage, the stage that Gilbert (1890, pp. 93-125) referred to as the Bonneville stage.

The shoreline of the Bonneville stage is one of the most striking topographic features in the region, as is the high-water mark of any ephemeral pond. It is the boundary between two very different kinds of landforms, the higher of which is the product of fluviatile erosion, and the lower the product of lacustrine erosion and sedimentation.

But despite its prominence as a topographic feature the Bonneville stage is barely represented as a stratigraphic unit in the lake sediments. The Bonneville formation has been recognized only as a thin and discontinuous beach deposit along the high shoreline and in a spit at the Point of the Mountain. Elsewhere in the valley the formation has not been recognized and beds assigned to the Provo formation rest directly upon the Alpine formation.

In the vicinity of Provo some beds assigned to the Bonneville formation are sand, but elsewhere the formation is largely gravel. In the narrow discontinuous beach deposits along the front of the Wasatch Range and south side of the Traverse Mountains much of the gravel is shingled and only a few feet thick. It unconformably overlies the Alpine or older formations.

At the mouth of American Fork Canyon the gravel in the Bonneville formation is more rounded and less shingled than along the rest of the mountain front and forms a rather extensive sheet of gravel, 20 feet or more in thickness, resting on the Alpine formation.

Only at the Point of the Mountain is the Bonneville formation a considerable deposit. Here the formation is composed of gravel and sand that was deposited in a huge spit 300 feet high and extending 1 mile west from the end of the Traverse Mountains. In this gravel are granitic pebbles derived from the Wasatch Range 
6 miles to the east. It is possible however that the voume of the Bonneville formation even in this spit is less than it appears to be, for we do not know the extent of the Alpine or other formations under the Bonneville in the spit.

Above the town of Alpine the Bonneville formation is derived from glacial outwash and, like the moraines there, is composed almost entirely of granitic sand, gravel, and cobbles. Evidently the glaciers were discharging large volumes of melt waters into the lake at the time the lake rose to its maximum height.

\section{PROVO FORMATION}

Most of northern Utah Valley is covered by the Provo formation, which includes the deposits that were laid down while Lake Bonneville stood at what Gilbert (1890, pp. 126-134) called the Provo stage. The formation is divided into four members distinguished by their prevailing texture - gravel, sand, silt, or clay.

Along Dry Creek, below the town of Alpine, the Provo formation overlies glacial outwash which in turn rests on the Alpine formation (fig. 8). Locally, as at Pleasant Grove and in the western part of the valley, the Provo rests on pre-Lake Bonneville deposits and at these places the Alpine either was not deposited or was removed by erosion before the deposition of the Provo.

In most of the valley the Provo rests on the Alpine formation and in the interior of the valley the contact seems to be fairly regular. Along Jordan River, from the Narrows nearly to Utah Lake, the contact is along a smooth bedding surface. At the contact there commonly is a thin, lenticular layer of sand which may be a sandy facies of the glacial outwash. West of the Geneva Steel plant, however, outcrops and drill holes show that the contact there is undulatory through a vertical range of 13 feet in a horizontal distance of about $1,500 \mathrm{ft}$. (See fig. 7.)

Around the edge of the basin the contact, no doubt, has many irregularities. Near the north side of Highland bench, 2 miles southwest of Alpine, is a solitary hill rising above the delta surface. Gravel, sand, and silt that are grouped together as sand on the map (pl. 1), comprise the hill and are thought to be part of the Alpine formation. No contacts were found, but the hill is presumed to be more ancient than the delta which partly buries it.

Few vertebrate remains have been found in any of the Lake Bonneville formations, a fact noted by Gilbert (1890, p. 210). Articulated remains of mammoth, however, were found (Hansen, 1928) near Payson, in the southern part of Utah Valley, “ $* * *$ in a thin bed of fine clay fifteen feet below the surface of the terrace gravels of $* * *$ the Provo stage $* * *$,
Gravel member.-The gravel member of the Provo formation occurs principally as delta deposits at the mouths of the large streams issuing from the Wasatch Range. It also occurs as littoral embankments between the deltas, as small bars in front of the deltas, and as a spit at the Point of the Mountain.

At the front of the deltas the thickness of the gravel member generally exceeds 100 feet. For example, between Dry Creek and American Fork River, the bluffs in front of Highland bench are about 175 feet high; east of American Fork River they are 100 feet high; and west of Dry Creek they are 150 feet high. The bluffs at the west edge of Orem bench $1 \frac{1}{2}$ miles southeast of the Geneva Steel plant are about 125 feet high, although they are only 75 feet high at the north and south ends of the bench. These keights.
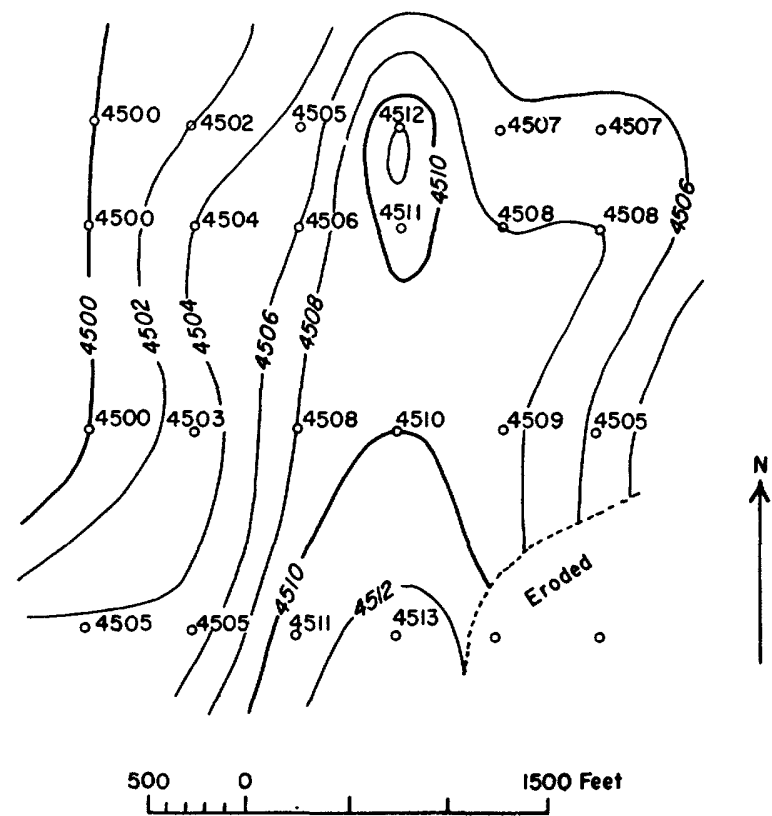

Frgure 7.-Contour map showing configuration of the base of the clay member of the Provo formation in part of sec. 7, T. 6 S., R. 2 E. Map based on the logs of 24 holes drilled to test the reservoir site for the Geneva Steel plant. Drill holes shown by dots; elevation of base of Provo formation shown beside each hole.

provide an approximate measure of the thickness of the delta at its distal end because the bottomset beds in front of the delta are only 25 to 30 feet in thickness.

The texture and degree of bedding in the gravel member vary with the position in the delta. Throughout the deltas the topset beds, presumably representing subaerial parts of the deltas, are poorly sorted, as are other fluviatile deposits. At the apex of the Highland bench and Orem bench deltas only the topset beds are exposed and their gravel deposits include many boulders a foot or more in diameter, the percentage of fines is low, the sorting is poor, and the bedding indistinct. Toward the distal ends of the deltas the topset beds thin and the foreset beds become distinct. In the 
foreset beds the proportion of fines is high. Many of the beds of gravel are composed of pebbles only $1 / 2$ or 1 inch in diameter. Interbedded with these are beds of still finer gravel and sand; beds of cobbles are comparatively few. Sorting is excellent.

Gravels deposited by Provo River contain about two pebbles of quartzite for each pebble of limestone or dolomite. (See fig. 15.) Gravels deposited by American Fork River include about as much limestone or dolomite as quartzite. The west part of Highland bench includes considerable granitic material con- tributed by Dry Creek. There is considerable sand and silt with these gravel deposits with the result that the member, although permeable, is not excessively so. The high content of sand and silt is illustrated by the two following mechanical analyses reported by Sanchez and representing material he collected at localities that are on the deltaic gravel. Presumably he excluded stones larger than 2 millimeters in diameter (Sanchez, 1904, pp. 11, 12):

Mechanical analyses of gravel member of Provo formation

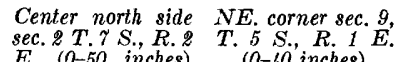

Sand $0.25-2 \mathrm{~mm}-15.08 \quad 40.50$

Sand $0.05-0.25 \mathrm{~mm} \ldots$

Silt and Clay $0.05 \mathrm{~mm} \ldots \ldots \ldots$ 39. $40 \quad 16.60$

The surface layers of the gravel member contain large quantities of calcium carbonate. Part of this calcium carbonate apparently was deposited at the top of a fluctuating water table; part seems to have resulted from surf action in Lake Bonneville. Very little of the calcification in these gravel deposits appears to be due to soil processes. (See p. 35.)

In both the Highland bench and Orem bench deltas the gravel constitutes a central facies that grades northwestward into a sandy facies, and southeastward into silt. The pebble drift indicates northerly currents along this eastern shore of Lake Bonneville, and the facies changes within the deltas suggest the same. The sand was carried north beyond the gravel while mud accumulated in what was probably a quiet eddy on the southwestern side.

In the old shore embankments between the deltas and at the spit at the Point of the Mountain gravel beds are similar to those at the distal ends of the deltas. Many of the beds are fine gravel and they contain a high percentage of fines; their sorting is excellent and their bedding distinct. The gravel mantles wave-cut terraces in the older deposits and lies against a steep slope of the older materials at the inner edge of the terrace. At the outer edge of the terrace, gravel was spilled onto the pre-lake slope and the terrace widened by deposition. Thus an embankment deposit may be only a few feet thick where it lies on the flat surface of a wave-cut terrace, but it may be scores of feet thick where it has been constructed outward onto the old sloping surface.

The embankment deposits have the same internal structure as the deltas and resemble the deltas lithologically. Foreset beds slope obliquely toward the lake and show the direction in which the embankment was built. Topset beds truncate the foresets, and bottomset beds extend from the foot of the foresets.

Gastropod shells are rather plentiful in the gravel member where it forms the spit at the Point of Mountain, but elsewhere few shells have been observed in this member.

In front of the Highland bench the gravel member forms some small gravel bars; one of the best-formed ones is at the bend in the road near the center of the S1/2, sec. 11, T. 6 S., R. 1 E. These bars extend northwest, and at their southeast ends they are connected with the delta front, indicating that they were deposited by northwesterly currents. Apparently they overlie silt or other fine-grained sediments.

Sand member.-The sand member of the Provo formation represents three kinds of deposits: deltaic deposits, bars in front of the deltas, and bottomset or foreset beds where the gravel member in embankments grades outward into the finer-grained lake bottom sediments.

In both the Highland bench and Orem bench deltas the sand member comprises a facies lying northwest of the gravel member and apparently represents sand that was winnowed from the gravel by northwesterly currents. The sand grains in these deltaic deposits are moderately rounded. Commonly the grains have plane sides, although the ends are round. Few have angular corners (fig. 4). Sanchez (1904, p. 15) made the following mechanical analysis of a sample taken from the north end of Orem bench:

Mechanical analysis of sand sample from center north side, sec. sec. $3, T .6 S ., R .2 E$.

0-24 inches 24-72 inches

Sand 0.10-2 mm ...

Sand $0.05-0.10 \mathrm{~mm} \ldots 8^{\circ}$

Silt $0.005-0.05 \mathrm{~mm}$

Clay $0.0001-0.005 \mathrm{~mm} \ldots \ldots \ldots 2.32$

The upper sample contained 3 percent, and the lower contained 13 percent of calcium carbonate. Like the gravel member in the deltas, this sand contains considerable silt and only in a few places is the ground excessively permeable or mantled by wind-blown sand.

Bedding in these sand deposits is fairly distinct. At the northwest end of Highland bench the sand, like the gravel interbedded with it, is in steeply dipping 
foreset beds. At the north end of Orem bench, on the other hand, are many feet of almost horizontally bedded sand, probably topset beds. In that sandy part of the delta foreset beds were not found.

In front of the deltas are a series of sand bars. Those in front of Orem bench are several miles long, a few hundred feet wide, and a few feet high. They were deposited on lake-bottom silt and clay by currents that moved northward along the front of the delta. The road southward from the Geneva Steel plant to Provo is on the outermost bar. The bars in front of Highland bench are similar though less well developed. They contain more gravel than do those in front of Orem bench and they are lower, shorter, and wider. Some of the bars may have been built as shallow subaqueous features, some may have been built into beaches. Because they rest on the lake bottom silts or clays they must have been late in the Provo stage, probably while the ancient lake was shrinking to the level of Utah Lake.

No good cuts in these bars have been found, so their internal structure and the details of their composition are still inadequately known. Some grab samples from the bars in front of Orem bench indicate that the sand there is rather clean quartz sand, the grains are very well rounded (fig. 4) and the common size is less than 0.5 millimeter in diameter. At many places the wind has blown the sand into small dunes.

A mechanical analysis of a sample to a depth of 6 feet at the northeast corner sec. 28 , T. 6 S., R. 2 E., was reported by Sanchez (1904, p. 12) to contain the following:

Mechanical analysis of sand from bar in front of Orem bench

Percent

Sand $0.5-1 \mathrm{~mm}$

Sand $0.25-0.5 \mathrm{~mm} \ldots$

Sand $0.10-0.25 \mathrm{~mm} \ldots$

Sand $0.05-0.10 \mathrm{~mm} \ldots \ldots \ldots \ldots$

Silt and clay 0.0001-0.05 mm _. _ _

The sand contains very little silt, clay, or calcium carbonate.

Where the gravel member forms a considerable embankment deposit, as at Camp Williams on the west side of Jordan River, the sand member forms a facies intermediate between the gravel in the embankment and the silt member that was deposited in the quieter water offshore. At these places the sand member forms the bottomset beds that extend lakeward from the foot of the gravelly embankments. Gastropods are abundant in these sand deposits that grade into the finer-grained lake bottom sediments.

The skull of a ground squirrel, identified by D. H. Johnson of the U. S. National Museum as Citellus townsendii mollis, was found where the sand member overlaps pre-Lake Bonneville fanglomerate in sec. 32 , T. 4 S., R. 1 E. This is a modern species widely distributed in the Great Basin. The skull evidently was washed in from the adjoining hills because nearby, but probably in the same bed, were found aquatic shells that were identified by Dr. Teng-Chien Yen, of the National Museum, as "embryonic shells and fragments of Valvata cf. V. utahensis Call."

Silt member.-The silt member of the Provo formation forms a part of each of the deltas, but is most extensive in a facies intermediate between the deltaic or other coarse shore deposits and the clays that accumulated in the interior of the old lake. The silt is gradational into the coarser-textured members and into the more finely textured clay member. The boundaries of the silt number as shown on the map (pl. 1), especially the boundary with the clay member, are arbitrary and based on - rather superficial field tests. Systematic sampling and laboratory tests will be needed to map accurately the boundary between the silt and clay. Off the fronts of the deltas and embankments the silt, about $20 \mathrm{ft}$ thick, is light gray, rather homogeneous, and is much less well bedded than is the silt member of the Alpine formation. Mechanical analyses of five samples of the silt are given in figure 13 .

A mechanical analysis of a sample that apparently was taken from this part of the silt member, at a locality near Ṕleasant Grove, has been reported by Sanchez (1904, p. 17) as follows:

\section{Mechanical analysis of silt member of Provo formation [Northeast corner sec. 20, T. 5 S., R. 2 E. Sample from 0-72 inches]}

Sand, $0.10-2 \mathrm{~mm} \ldots \quad \begin{array}{r}P e r c e n t \\ 0.66\end{array}$

Sand, 0.05-0.10 mm

Silt, $0.005-0.05 \mathrm{~mm} \ldots 23.04$

Clay, 0.0001-0.005 mm 73.20

Calcium carbonate.

Fossil ostracodes and gastropods are rather abundant in the silt member in front of the deltas, especially in a layer about 1 foot above the base. In places this layer is almost a coquina.

A collection of ostracodes from the base of the silt member in the Denver \& Rio Grande Western Railroad cut at the southeast corner sec. 26, T. 6 S., R. 1 W. were examined by Fred M. Swain who has identified the following species:

Candona ef. C. candida (Muller) Common.

Candona cf. C. lactea Baird Common.

Limnicythere of. L. sancti-patricii Brady and Robertson Common.

Limnicythere ef. L. inopinata (Baird) Common.

Limnicythere n. sp. aff. Cytheridea lacustris (G. O. Sars) Abundant. 
According to Swain:

These species are Holaretic and typically are fresh-water lacustrine types, but Limnicythere inopinata has also been obtained from brackish tidal waters. Its presence might suggest that Provo Lake became slightly saline seasonally, but as the species also occurs in fresh water, such evidence is not conclusive. "Cytheridea" lacustris (Sars) (probably closer to Limnicythere), to which one of the forms from this locality is related, occurs both in fresh and brackish water. As Candona lactea seems to have been taken more often from rivers, its presence here may indicate that it was washed into Provo Lake by streams.

Gastropods associated with the ostracodes at the locality in the railroad cut were submitted to Teng-Chien Yen, who indentified the following species:

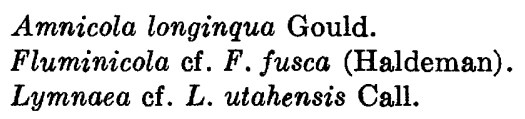

Yen reports that these (species) are still living in a large area west of the continental divide, including Utah, generally in shallow still water where there is a rich growth of vegetation.

A small jaw found in the silt west of Utah Lake, near the southeast corner sec. 12, T. 65., R. $1 \mathrm{~W}$. was identified by C. L. Gazin, of the National Museum, as belonging to a pocket gopher, apparently in the group Thomomys talpoides.

Analyses for soluble salts in samples from the prodelta silt deposits indicate that they commonly contain a percent or so of chlorides, sulfates, and carbonates, and that the quantity of these salts increases lakeward. (See table 14.)

The silt member also is found in the southern part of each of the deltas. Excavations on Highland bench show that the silt there is at least 10 feet thickhow much thicker is not known. The silt is light tan and massive. No fossil shells were found in it. The origin of these silt deposits on the deltas is obscure. Perhaps they are water-laid sediments that were deposited in a bayou on the delta, and if so they are properly a part of the Provo formation. But their uniformly fine texture and indistinct bedding suggest that they might be windblown deposits; if this is correct they would be younger than the Provo.

Another deposit of the silt member is exposed along Dry Creek just below the town of Alpine. This deposit, about 6 feet thick, overlies glacial outwash and is overlain by post-Bonneville fluviatile deposits. The silt member is poorly bedded and contains considerable sand, and some thin lenses of granitic grit. The deposit seems to have been formed as a result of the ponding of Dry Creek when it was dammed by the gravels that were deposited across its course by American Fork River. The only fossils found in this silt are gastropods that have been identified by Teng-Chien
Yen as Succinea avara Say and Oreohelix strigosa depressa (Cockerell). Yen states that these are terrestrial snails and that both species still live in the region.

The silt member commonly lies unconformably on the Alpine or older formations. Along Jordan River it overlaps the gravel member of the Alpine (pl. 1); at Pleasant Grove and at numerous places along the west side of the valley the silt overlaps pre-Lake Bonneville alluvial fans. In front of the deltas the silt is overlain by gravel or sand bars and by postLake Bonneville alluvial deposits.

Clay member.-The clay member of the Provo formation was deposited in the interior of the lake. Like the silt member it ranges from 10 to 20 feet in thickness, and is light gray and rather homogeneous. It also resembles the silt member in that it is indistinctly bedded.

Some mechanical analyses of the clay are given on figure 13. Other analyses made by engineers testing foundations for the Geneva Steel plant indicate that 70 percent of the samples are finer than 0.02 millimeter in diameter, 45 percent are finer than 0.005 millimeter, and 10 percent are finer than 0.001 millimeter. Another analysis, reported by Sanchez $(1904$, p. 16), is as follows:

Mechanical analysis, in percent, of samples from the northeast corner of sec. 7, T. 5 S., R. $1 \mathrm{E}$.

$\begin{array}{rr}(0-30 \text { in. }) & (30-72 \text { in. }) \\ 4.10 & 3.78 \\ 14.64 & 10.32 \\ 43.08 & 19.92 \\ 37.80 & 66.90 \\ 11.4 & 26.2\end{array}$

Sand, 0.10-2 $\mathrm{mm}$

Sand, 0.05-0.10 mm

Silt, $0.005-0.05 \mathrm{~mm}$.

Clay, 0.0001-0.005.

11. 4

26. 2

The part of the sample from 30-72 inches is probably from the clay member of the Provo formation; the top 30 inches may be younger silt.

Ostracodes seem to be more abundant and gastropods fewer in the clay than in the silt member. Commonly there is a concentration of shells about a foot above the base of the clay. Ostracodes collected from the clay member of the Provo formation by Utah Lake, 1 mile west of Geneva Steel plant, about the center of sec. 7, T. 6 S., R. 2 E. were examined by Fred M. Swain who identified the following: Candona sp. aff. C. candida (Muller)-mostly broken fragments. Swain states:

This species is Holaretic in its distribution, and is found in Europe and North America. It occurs in almost every freshwater environment, and in some of the brackish, tidal areas of England and Europe. It prefers still water to running water.

In another collection from the base of the clay member along Jordan River, in sec. 1, T. 5 S., R. 1 W., Swain identified:

Candona ef. C candida (Müller) Common.

Limnicythere n. sp.? aff. Cytheridea lacustris (Sars) Common. 
A third collection of shells from a bed believed to be part of the Provo formation by Utah Lake in the NE1/4 sec. 35, T. 5 S., R. $1 \mathrm{~W}$. contains a variety of ostracodes and mollusks. Swain reported on the ostracodes as follows:

Candona of. C. candida (Muller) Abundant.

Candona cf. C. lactea Baird Common.

Cypridopsis sp. Rare.

Limnicythere sp. aff. L. inopinata (Baird) Rare.

Limnicythere n. sp.? aff. Cytheridea lacustris (Sars) Rare.

Cytheridea cf. C. torosa (Jones) Very abundant.

He states:

The faunule is Holarctic. Candona lactea may have been washed in by streams. Cytheridea torosa has been taken in fresh water, but seems to be found more typically in a brackish to nearly normally saline environment. Its presence in such abundance suggests that the prevailing environment was more or less saline. Seasonal changes might account for the presence of the other more typically fresh-water forms. Hoff (The ostracods of Illinois, Illinois Biol., Monographs, Univ. Illinois Press, 1942, p. 33) says that many of the modern nonmarine forms are seasonal, the eggs deposited in one season remaining attached to some substratum, usually plants until the next favorable season.

Dr. T. C. Yen reported on the mollusks as follows:

Sphaerium pilsbryanum Sterki.

Pisidium sp. undet.

Valvata utahensis Call.

Amnicola sp. undet.

Fluminicola fusca (Haldeman).

Pompholopsis cf. P. whitei Call.

Carinifex newberryi (Lea).

Lymnaea utahensis Call.

Physa lordi Baird.

Physa cf. P. ampullacea Gould.

He states:

Practically all the identifiable species are found, according to the known records, in the Recent fauna of the Utah Lake and therein a similar assemblage of species may be found, so that the environmental conditions were much the same as they are now. The habitat suggested is that of a rich aquatic shore vegetation, possibly a somewhat marshy area.

Soluble salts are more abundant in the clay than in the silt member and their quantity increases lakeward. Moreover, thie clay member of the Provo formation contains about twice as much soluble salts as does the silt and clay member of the Alpine formation. (See p. 33.)

The clay member of the Provo formation lies unconformably on the Alpine formation and is overlain by Post-Lake Bonneville alluvial deposits. West of the Geneva Steel plant the base of the clay member of the Provo is undulatory (fig. 7), and the nearly horizontal clay overlies beds of the Alpine formation which dip rather steeply to the east. The irregularities in the contact presumably reflect structural or erosional irregularities in the upper surface of the Alpine, rather than bars or other constructional features at the top of that formation.

\section{CONCEALED PLEISTOCENE DEPOSITS}

Nearly all wells drilled in the valley penetrate the Lake Bonneville group to obtain water from the underlying gravels or sand of the pre-Lake Bonneville Pleistocene deposits. Most of these wells are flowing wells drilled in the lower parts of the valley where the Alpine, Bonneville, and Provo formations are represented by clayey deposits, and these impermeable beds of fine texture confine the water under artesian pressure in the pre-Lake Bonneville deposits.

Drillers' logs of wells indicate that the clay deposits are relatively thin in the northeastern part of the valley, along the flank of the Traverse Mountains, and become thicker to the south. Section $F-F^{\prime}$ on plate 4, a geologic section parallel to the base of the Wasatch Range, is based on well logs, and shows that the Lake Bonneville group increases in thickness from about 25 feet near Lehi to 160 feet near Provo. Other geologic sections indicate that within the area of well construction the clay and silt deposits are thickest in the interior of the valley and become progressively thinner toward its eastern edge.

The logs tabulated below show some of the characteristics of the concealed Lake Bonneville and older deposits in Utah Valley. The wells are located respectively on the recent alluvial fans of Dry Creek, American Fork River, and Provo River. The deposits of the Lake Bonneville group in each well are predominantly clay, but some sandy or gravelly beds are included in the section, and some of these are interpreted to mark the contact between the Provo and Alpine formations.

The well number indicates the location of the well with reference to land subdivision according to a system adopted by the Utah State Engineer and described in his Twentieth Biennial Report, p. 87, 1936. Briefly, the State is divided into four quadrants by the Salt Lake base and meridian, and these quadrants are designated by capital letters: $A$ for the northeast quadrant, representing townships north and ranges east; $B$ for the northwest quadrant; $C$, the southwest; and $D$, the southeast. In the well number the designation of the township is enclosed in parentheses and includes one of these letters, a figure showing township, and a figure showing range. In the number of the well here cited the portion within parentheses indicates that the well is in T. 5 S., R. 1 E. The number following the parentheses designates the section, and the lower-case letters following the section number give the location within the section, quarter-section, and sixteenth section (the letters $a, b, c$, and $d$.representing the northeast, northwest, southwest, and southeast quarters of each subdivision). The final number designates the particular well within the 10- 
acre tract. Thus, number (D-5-1) 8dcc-1 (see below) represents well 1 in the $\mathrm{SW} / 4 \mathrm{SW}_{1 / 4} \mathrm{SE}^{1 / 4}$ sec. 8 , T. 5 S., R. 1 E.

\section{Driller's log of Lehi Irrigation Co. well $(D-5-1) 8 d c c-1$}

[State claim no. 11094. Unused well drilled 240 feet deep in June 1934 by F. G. Farris. Elevation of land surface at well, 4,555 ft]

Post-Provo deposits (Recent and Pleistocene?): Aluvium (Recent) (7 feet):

Gravel . .

Sand and gravel

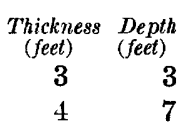

Lake Bonneville group (Pleistocene):

Provo formation (18 feet):

Clay, light-gray ................. 13

Clay and gravel $\ldots$

Alpine formation ( $54 \mathrm{feet}$ ) :

Clay, brown

Sand and gravel........

Clay, sandy, blue.....................

Pre-Lake Bonneville deposits (Pleistocene) :

Shallow artesian aquifer (29 feet):

Gravel, water-bearing

Clay

Clay and boulders .......................

Gravel, water-bearing

Lacustrine(?) clay (45 feet):

Clay, yellow

Intermediate artesian aquifer (71 feet) :

Gravel, water-bearing . .................

Clay, yellow ...........................

Gravel, water bearing ..............

Clay, yellow

Gravel, water-bearing ..................

Clay . . . . . . . . . . . . .

Sand, water-bearing

Lacustrine(?) clay:

Clay, sandy

Clay, blue.

Driller's log of Drought Relief Adm. well (D-5-1) 10 cab-1

State claim no. 8308 . Unused well drilled 400 feet deep in October 1934 by F. G. Farris. Elevation of land surface at well, 4,661 feet]

Post-Provo deposits (Recent and Pleistocene?): Alluvium (Recent) (41 feet):

Soil .

Sand.

Lake Bonneville group (Pleistocene):

Provo formation (33 feet):

Sand, fine..............................

Clay, sandy

Sand and fine gravel.............. 11

Alpine formation (28 feet):

Clay -

Clay and sand

Pre-Lake Bonneville deposits (Pleistocene):

Shallow artesian aquifer ( 47 feet):

Gravel and boulders....

Lacustrine(?) clay (60 feet):

Clay, yellow

Clay and sand
Thickness Depth

$\begin{array}{rr}\text { (feet) } & (\text { feet }) \\ 8 & 8\end{array}$

33

41

$7 \quad 48$

1563

$11 \quad 74$

$20 \quad 94$

$8 \quad 102$

47

149

$17 \quad 166$

$43 \quad 209$
Driller's log of Drought Relief Adm. well (D-5-1) 10 cab-1Continued

Pre-Lake Bonneville deposits (Pleistocene)-Continued

Intermediate artesian aquifer (75 feet):

$\begin{array}{cc}\begin{array}{c}\text { Thicknses } \\ \text { (feet) }\end{array} & \begin{array}{c}\text { Depth } \\ (\text { feet })\end{array} \\ 36 & 245 \\ 6 & 251 \\ 3 & 254 \\ 18 & 272 \\ 12 & 284 \\ & \\ 23 & 307 \\ 15 & 322 \\ 18 & 340 \\ 4 & 344 \\ 8 & 352 \\ 6 & 358 \\ & \\ 20 & 378 \\ 2 & 380 \\ 2 & 382 \\ 2 & 384 \\ 12 & 396 \\ 4 & 400\end{array}$

Driller's log of Jacobson and Smith well (D-7-2) 12cdb-2 [State application no. 12866. Irrigation well drilled 226 feet in July 1939. Elevation

Post-Provo deposits (Recent and Pleistocene?):

Alluvium (Recent) (45 feet):

Soil _

Thickness
(feet) $\quad \begin{aligned} & \text { Depth } \\ & \text { (feet) }\end{aligned}$

Gravel, coarse

Lake Bonneville group (Pleistocene):

Provo formation (35 feet):

Clay, blue $\ldots \ldots$

Sand

Alpine formation (84 feet):

Clay, blue . . . . . . . .

Gravel

Clay, blue...................... $40 \quad 164$

Pre-Lake Bonneville deposits (Pleistocene):

Shallow artesian aquifer:

Gravel .......... $16 \quad 180$

Clay

Gravel, water-bearing .............. $10 \quad 226$

The log of the Orem city well shows that the thickness of the Lake Bonneville group under the. Orem bench may be about 210 feet. The deltaic gravel and sand of the Provo formation has a total thickness of about 120 feet and rests upon the clay member of the Alpine formation, 90 feet thick.

\section{Driller's log of Orem city well (D-6-2) $11 b c c-1$}

[State application no. 17238. Municipal well drilled 469 feet deep by $\mathrm{L}$. W. Dalton in March 1946. Elevation of land surface at well about 4,782 feet]

Lake Bonneville group (Pleistocene):

Provo formation (117 feet):

Cobbles and gravel (perched water) ....

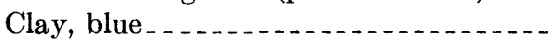

Quicksand (perched water)

Alpine formation (90 feet) :

Clay, blue.

\begin{tabular}{cr}
$\begin{array}{c}\text { Thickness } \\
\text { (feet) }\end{array}$ & $\begin{array}{r}\text { Depth } \\
\text { (feet) }\end{array}$ \\
$\mathbf{5 4}$ & $\mathbf{5 4}$ \\
$\mathbf{2 0}$ & $\mathbf{7 4}$ \\
$\mathbf{4 3}$ & 117 \\
& \\
& \\
\hline
\end{tabular}

207 
Driller's log of Orem city well (D-6-2) $11 b c c-$ Continued

Pre-Lake Bonneville deposits (Pleistocene):

Shallow artesian aquifer (141 feet): Clay and gravel $\ldots r .31 \quad 238$

Sand, coarse $\ldots \ldots \ldots$

Boulders and sand ................ $81 \quad 328$

Clay, yellow . . .

Sand ......... 11348

Lacustrine(?) clay (61 feet):

Clay, yellow; some sand ............. $\quad 19 \quad 367$

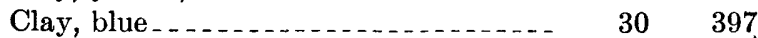

Clay, yellow

Clay, blue....................... 8409

Intermediate artesian aquifer:

Boulders; some clay............... $27 \quad 436$

Boulders, gravel, sand; water-bearing--- $\quad 33 \quad 469$

GLACIAL DEPOSITS

Glacial deposits in northern Utah Valley are of two kinds: moraines and outwash sediments. Two moraines are exposed at the mouth of Alpine Canyon, about 21/2 miles northeast of the town. Outwash from the morainal deposits crops out along Dry Creek and extends at least a mile southwest of Alpine.

\section{MORAINES}

Atwood examined the glacial basin and moraines in Alpine Canyon and has given the following description of them (Atwood, 1909, pp. 78-79).

The white granite walls about the basin are smoothed and the loose material of the slopes have been largely cleaned away. Roche moutonnee surfaces are common about the head and on the slopes of the valley. The catchment basin and the valley below show signs of vigorous ice action, resulting from a gradient of more than 1,000 feet per mile, over which the glacier descended.

The lower part of the valley contains a large amount of drift. Lateral moraines lie high on the slopes, and the outer and upper two on either side appear much older than those within and below. Their greater age is shown not only by their position but by the relatively large amount of erosion and disintegration which they have suffered.

The material of the outer moraines is so disintegrated as to form a thick mantle of soil, while the inner and lower deposits show an insignificant amount of postglacial weathering. Many of the crystalline rocks on the surface of the outer moraines have crumbled. Others are about ready to crumble and fall to pieces if struck with the hammer. The surface boulders of the inner series of moraines are so fresh that striae are preserved on their surfaces. They appear not to have been in the least affected by weathering.

The contrast in age between the two series of moraines is also shown by the more numerous and deeper erosion lines in the outer series. The more recent deposits show but insignificant gully lines, while the outer moraines are considerably dissected.

These facts, strengthened by similar data from other canyons, justify the following conclusions:

(1) That there were at least two distinct glacial epochs in the region; (2) that, so far as thickness of soil may furnish a basis for estimating time, the interglacial period was much longer than that which has elapsed since the last retreat of the ice; (3) that during so long an interglacial period a notable amount of $247743-53-3$ erosion must have taken place; (4) that the ice of the earlier period was more extensive than the ice of the later period.

The difference in the soil that has formed on the two deposits, as noted by Atwood, is indeed striking. The parent material in both moraines is largely granitic. On the older moraine reddish-brown sticky clay has developed in the upper layers of the soil to a depth of at least 2 feet. Beneath this is another 2 feet of yellowish-brown, but clayey, sand and grit. In both these layers the granite pebbles are rotten and easily crushed in the hand. Beneath these layers is about 3 feet of sand and grit containing weathered but comparatively firm granite pebbles and cobbles, and below this is a zone containing tiny veinlets of lime carbonate. On the younger moraine fresh boulders are abundant at the surface. Only locally has clay been formed at the surface, and this is very sandy and light-colored compared to the clayey layers at the surface of the old moraine.

No exposure was found of the contact between the two moraines. There is little, therefore, to add to Atwood's conclusions or to the evidence on which he based his conclusions. It should be noted however that the deep soil on the old moraine is not valid evidence that the interglacial period was longer than the time that has elapsed since the last retreat of the ice. That soil is the product of past climates that may have been utterly unlike the climate that has prevailed since glacial time. Indeed there is reason to question whether so deep a soil could be developed on hillside environments under the feeble processes of the present climate. (See p. 45.)

The older moraine seems to have been displaced about 100 feet along the fault that crosses Dry Creek 2 miles northeast of Alpine. The younger moraine did not reach quite to the fault, but the outwash from that moraine does not appear to be faulted.

Atwood (1909, p. 79) indicated that the Alpine Valley glacier advanced a mile beyond the Bonneville shoreline, but this is incorrect. The distinctly morainal ridges end below the canyon mouth but a mile upstream from the Bonneville shoreline, which here is an ill-defined feature and probably was incorrectly identified during his reconnaissance.

Despite the fact that Alpine Valley traverses Paleozoic sedimentary formations as well as the granite of the Little Cottonwood stock, the moraines and glacial outwash are composed very largely of granitic materials, because the glaciers headed on the granitic, north side of the valley.

Other glacial moraines are farther up Alpine Canyon and in the headward parts of American Fork River and some tributaries of Provo River. 
GLACIAL OUTWASH

Glacial outwash from the younger of the glaciers that reached the mouth of Alpine Canyon fills the valley of Dry Creek from the mouth of the canyon to approximately the shoreline of the Bonneville stage and is exposed intermittently farther downstream where it rests on the Alpine formation and is overlain by the Provo formation. The glacial outwash is composed very largely of granitic material and is readily distinguished from the other fluvial gravels along Dry Creek which contain only about 30 or 40 percent granitic pebbles.

Near the mouth of Alpine Canyon boulders 6 feet in diameter are abundant in the outwash. At the Bonneville shoreline the large boulders are commonly about a foot in diameter. The Bonneville formation here is composed very largely of granitic material and apparently was built of the outwash from the younger moraine.

The outwash above the shoreline undoubtedly overlaps the old pre-Lake Bonneville alluvial fan that was built by Boxelder Creek, a canyon south of Alpine Canyon, but the contact between these two deposits was not found. The fanglomerate that overlies the outwash immediately south of Dry Creek is 40 feet thick and contains no granitic material. It is believed to be outwash from a moraine high in the next valley south of Dry Creek.

Farther down Dry Creek from the shoreline of the Bonneville stage the outwash is largely concealed by alluvial deposits. The outwash is exposed near the mouth of Fort Canyon in the $\mathrm{NE}^{1 / 4}$ sec. 24 and in the south wall of Dry Creek half a mile below Alpine. This latter locality is particularly revealing, for the outwash, 6 feet in thickness, can be traced downstream under the gravel member of the Provo formation and on top of the Alpine formation. The glacial outwash is quite distinctive because of its high content of granitic pebbles, whereas the gravel member of the Provo formation, here derived mostly from American Fork Canyon, is composed almost entirely of limestone or quartzite pebbles -50 or more of these to 1 of granite.

The glacial outwash has not been recognized in the interior of the valley and evidently the gravel facies of the outwash did not extend far down Dry Creek. The contact between the Alpine and Provo formations along Jordan River, however, commonly is marked by a few inches of loose clean sand that may be a sandy facies of the outwash.

ALLUVIAL DEPOSITS OF PROVO(?) AGE

Some of the flood-plain deposits at Alpine and along Dry Creek upstream from the town probably were deposited during Provo time, but they are not shown separately on the map (pl. 1) because they cannot be distinguished satisfactorily from the younger alluvial deposits that partly mask them. These old alluvial deposits overlie the outwash from the moraine and they were probably laid down during Provo time.

The flood-plain deposits on which the town of Alpine is built probably are very largely correlative with the Provo formation. During Provo time American Fork River built its delta northwestward across Dry Creek about a mile below Alpine, and this seems to have dammed Dry Creek. The dam is composed only of topset beds and probably is largely of subaerial origin. The deposits upstream along Dry Creek are entirely of fluviatile origin (see fig. 8), and overlie the outwash

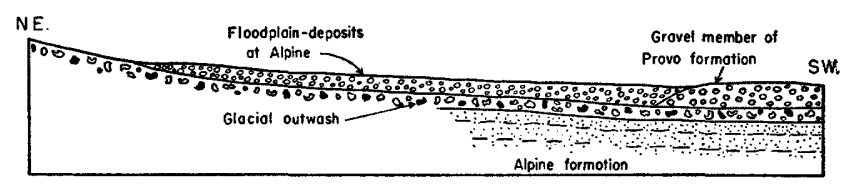

FraURE 8.-Diagrammatic section for about 2 miles along Dry Creek at Alpine. The glacial outwash is from the younger of the moraines at the mouth of Alpine Canyon. It rests on the Alpine formation and is overlain by the gravel member of the Provo formation derived from American Fork River. The flood-plain deposits on which the town of Alpime is built are believed to have been formed when Dry Creek was dammed by the gravels from American Fork River.

from the younger of the moraines at the mouth of Alpine Canyon. The surface of the Dry Creek floodplain is 1 or 2 feet lower than the surface of the delta, and its base is 20 to 25 feet lower.

POST-PROVO DEPOSITS (PLEISTOCENE(?) AND RECENT) ALLUVIAL DEPOSITS

Post-Provo flood-plain deposits are rather widespread along Provo River, American Fork River, and Dry Creek. These fluviatile deposits are gravelly and, like the topset beds on the deltas, are characterized by poor sorting, and indistinct and lenticular bedding.

Most noteworthy of these deposits is the large fan, mostly gravel, built on the clay and silt members of the Provo formation where American Fork River issues from Highland bench. At the town of American Fork this deposit is about 50 feet thick. It is 3 miles wide and thins radially southward from the town. The central part of the fan is composed of gravel. Around the fringe, and below about the 4,550-foot contour the fan is overlain by recent lacustrine silt which, however, is not differentiated on the map (pl. 1). The gravel in the fan is the kind transported by American Fork River, mostly limestone and quartzite. They are wellrounded but poorly sorted. Unlike the lake-deposited gravels only small amounts of secondary calcium carbonate have accumulated in the surface layers of this alluvial gravel despite the abundance of lime in the parent material. Sanchez $(1904$, p. 15) gives the following mechanical analysis of a sample he collected near the west edge of the gravel facies of this fan: 
Mechanical analysis, in percent, of alluvium in center of sec. 23, T. 5 S., R. $1 \mathrm{E}$.

Sand, 0.10-2 $\mathrm{mm}$ (0-80 inches) ( $80-60$ inches $)$ $15.04 \quad 7.58$ Sand, 0.05-0.10 mm 19.46 Silt, 0.005-0.05 mm _. Clay, $0.0001-0.005 \mathrm{~mm}$

Calcium carbonate. 39.6 7.58
19.48 44.00 28.70 47.2

At Lehi is another alluvial fan, built by Dry Creek on the lake-bottom clay or silt beds belonging to the Provo formation. This fan is about 30 feet high and about 2 miles wide. Within a few feet of the surface, the fan contains little gravel, and is composed mostly of fine sand and silt. These fine-grained sediments may be, in part, a lacustrine deposit overlying the alluvial material of the fan. Well logs (pl. 4, sec. F-F') suggest that the alluvial deposits may have a maximum thickness of about 50 feet, probably because of channeling into the underlying Lake Bonneville group.

Provo River has a wide gravel flood plain, and much of the town is built on silty beds, presumably lacustrine, that overlie the gravel. The Provo River fan is only about 15 feet high. Well logs show (pl. 4, sec. F-F') that channels have been cut into the Lake Bonneville group at least as far downstream as the city of Provo, and that these channels have been filled with coarse gravel and sand. The maximum thickness of these post-Provo alluvial deposits, according to well logs, is about 40 feet.

These three fans are composed of materials reworked from the deltas. As the level of Lake Bonneville fell, Dry Creek, American Fork River, and Provo River became incised in the unconsolidated deltaic deposits and the material removed from their channels was deposited in the fans.

Other post-Provo alluvial deposits are readily recognizable along the front of the Lake Mountains. These deposits are narrow and thin, generally only a few feet thick, and are distributed along the gullies and other stream courses that descend the fans at the foot of the mountains. Between these trains of very recent gravel and boulders are the undisturbed Lake Bonneville group and pre-Lake Bonneville alluvial deposits.

Other similar alluvial deposits overlie many of the old fans around the edges of the valley, but they are incompletely shown on the map. Elsewhere in the valley the post-Provo alluvial deposits are small.

\section{EOLIAN(?) SILT}

Not shown on the map is a layer of silt ranging from a few inches to 1 foot or more in thickness that blankets extensive areas in the upper benches and hillside slopes in the valleys. This silt is particularly conspicuous where it overlies gravel deposits like those in the deltas of the Provo stage. It is dark brown and rather homogeneous in texture, although at most places it contains a few pebbles like those in the underlying gravel. Locally it is free of pebbles but rather sandy. The lower part of the silt contains considerable carbonate but the top inch or so generally has been leached of its carbonate.

The silt appears to be a stratum distinct from and younger than the underlying gravel. It is nearly free of pebbles at places where the underlying gravel includes much quartzite so it is assuredly not a residual effect of weathering of the gravel. Moreover, the contact between the silt and underlying lime-cemented gravel commonly is sharp. The silt probably is largely an eolian deposit blown onto the higher parts of the valley when the old lake level fell and the lake-bottom sediments became dessicated. If so it has been considerably reworked, both artificially and naturally. Many of the pebbles in it perhaps were heaved upward by frost action.

LAKE DEPOSITS

In the bottom of Utah Lake is sediment that spans all the time that has elapsed since the Provo formation was deposited. Although lake sediments younger than the Provo formation have not been recognized around the shores of the present lake it is very possible that Utah Lake has risen as high as the 4,550-foot contour since Provo time, because below that level the alluvial fans at Lehi, American Fork, and Provo are overlain by silt that may be of lacustrine origin.

VERTEBRATE FOSSILS

Deposits presumed to be post-Provo in age have yielded mammoth remains at two localities in Utah Valley. One locality was in a marsh near the eastern shore of Utah Lake a few miles south of Provo (Gilbert, 1890 , p. 211). Another was near the city of Provo in gravel below the level of the Provo stage (Blackwelder, 1939, p. 892). The stratigraphic positions of the bones are not known. The localities are below the level of the Provo stage, and presumably the deposits that contained the bones are post-Provo in age. But the positions could not be below the Stansbury level (Blackwelder, 1939, p. 892) because the Stansbury was at or below the level of Utah Lake. Probably the mammothbearing deposits are little if any younger than the Stansbury stage. It is doubtful that any of the extinct animals that characterize the Pleistocene survived much longer than Stansbury time in the Lake Bonneville basin. At least no representatives of the extinct species have been found among the plentiful vertebrate remains collected from post-Stansbury deposits in the Great Salt Lake region (Stewart, 1937, pp. 81-82, 102, 118). 


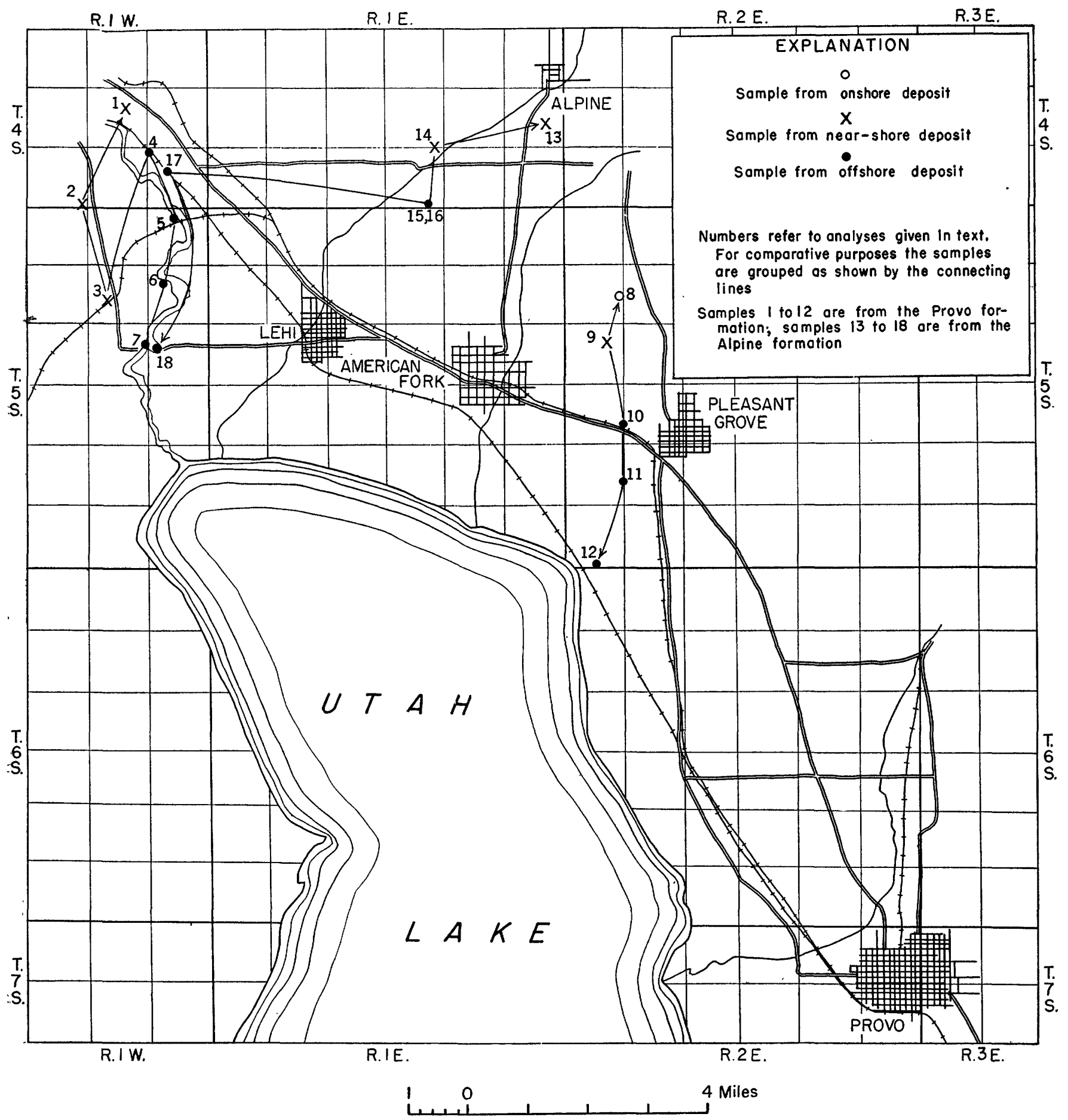

FIGURE 9.-Sketch map showing location of samples collected for chemical analyses. 


\section{SOME GEOCHEMICAL PROBLEMS}

ANALYSES AND OUTLINE OF SOME OF THE PROBLEMS

During a field conference in Utah Valley, Dr. Vladimer P. Sokoloff suggested testing the Lake Bonneville deposits to determine whether variations in their chemistry might be correlated with the paleogeographic conditions of deposition. It would be reasonable to suppose, for example, that the quantity and kind of soluble salts in the sediments would vary in an orderly way depending on the properties of each salt and the variations in conditions of sedimentation from one part of the lake basin to another.

As a first test of the hypothesis numerous field qualitative analyses were made for calcium, magnesium, sodium, potassium, carbonate, chloride, and sulfate. As orderly variations were found in the distribution of some of these constituents, a series of samples was collected for quantitative analyses. Eighteen complete rock analyses and 18 partial analyses for watersoluble salts were made by Norman Davidson, Margaret Foster, and W. W. Brannock in the chemistry laboratory of the Geological Survey. The analyses are given in tables 4 to 7 . Figure 9 shows the localities from which the samples were collected.

The samples were collected from the Alpine and Provo formations at localities that would provide a basis for three kinds of comparisons: comparisons between similar and contemporaneous deposits that had different sources; comparisons between similar

TABLE 4.-Complete analyses of silt and clay from Provo formation northwest of Dry Creek

[Analyses by Norman Davidson and W. W. Brannock, chémists, U. S. Geological Survey]

\begin{tabular}{|c|c|c|c|c|c|c|c|}
\hline & \multicolumn{2}{|c|}{ Near-shore deposits } & \multicolumn{5}{|c|}{ Offshote deposits } \\
\hline & 1 & 2 & 3 & 4 & 5 & 6 & 7 \\
\hline 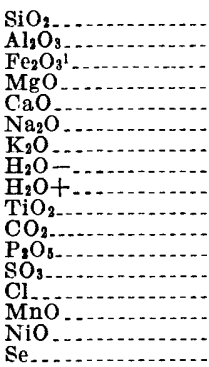 & $\begin{array}{r}50.4 \\
8.9 \\
2.9 \\
2.9 \\
13.0 \\
1.8 \\
1.7 \\
2.4 \\
2.3 \\
.5 \\
11.1 \\
.2 \\
.6 \\
.9 \\
.1 \\
0 \\
0\end{array}$ & $\begin{array}{r}54.4 \\
11.3 \\
4.0 \\
2.1 \\
9.8 \\
1.5 \\
2.0 \\
3.7 \\
3.1 \\
.5 \\
6.7 \\
.2 \\
.4 \\
.2 \\
.1 \\
0 \\
0\end{array}$ & $\begin{array}{r}52.6 \\
11.1 \\
3.6 \\
2.9 \\
10.4 \\
.7 \\
2.2 \\
3.1 \\
3.7 \\
.4 \\
8.1 \\
.2 \\
.4 \\
.1 \\
.1 \\
0\end{array}$ & $\begin{array}{r}51.4 \\
9.3 \\
3.0 \\
3.1 \\
13.3 \\
1.3 \\
1.8 \\
2.1 \\
1.6 \\
.5 \\
11.2 \\
.2 \\
.4 \\
.3 \\
.1 \\
0 \\
0\end{array}$ & \begin{tabular}{|r|}
49.6 \\
9.9 \\
3.3 \\
3.4 \\
13.0 \\
1.5 \\
2.2 \\
2.0 \\
1.8 \\
.5 \\
11.2 \\
.3 \\
.8 \\
.4 \\
.1 \\
0
\end{tabular} & $\begin{array}{r}48.3 \\
10.2 \\
3.3 \\
3.8 \\
14.1 \\
1.1 \\
1.8 \\
1.8 \\
2.1 \\
12.8 \\
.2 \\
.2 \\
.4 \\
.1 \\
0 \\
0\end{array}$ & $\begin{array}{r}45.2 \\
9.6 \\
3.3 \\
3.1 \\
15.8 \\
1.1 \\
1.8 \\
2.3 \\
2.1 \\
.5 \\
13.3 \\
.2 \\
.9 \\
.7 \\
.1 \\
0 \\
0\end{array}$ \\
\hline & 99.7 & 100.0 & 99.6 & 99.6 & 100.0 & 100.6 & 100.0 \\
\hline
\end{tabular}

1 Ferrous iron not determined because of the presence of organic matter.

1. 1,000 feet east of center, sec. 26, T. 4 S., R.1 W. From basal 24 inches of formation. 1. 1,000 feet east of center, sec. $26, \mathrm{~T} .4 \mathrm{~S}$., R.1 W. From basal 24 inches of formation. T. 4 S., R. $1 \mathrm{~W}$.

3. West of center sec. 11, T. 5 S., R. 1 W. 42 inches below surface.

4. D \& RGW RR cut. Northwest corner sec. 36, T. 4 S., R. 1 W. Sample cut from feet in lower part of formation. Base of sample about 1 foot above base of formation 5 S. R. 1 W.

6. Center NW $1 / 4$ sec. 12, T. 5 S., R. 1 W. Basal 4 feet of formation about 7 feet

below surface. $1 / 4$ sec. 13, T. 5 S., R. 1 W: 3-foot sample about 1 foot above base of formation. facies that were derived from the same source rocks but at different times and presumably under different conditions; and comparisons between near-shore and offshore deposits that had a common age and source.

Some comparisons also can be made between the water-soluble salts contained in the Lake Bonneville sediments and the salt content of modern Lake Utah. Some analyses of Utah Lake waters are given in table 8.

TABLE 5.-Complete analyses of silt and clay from Provo formation southeast of A merican Fork River

[Analyses by Norman Davidson and W. W. Brannock, chemists, U. S. Geological

\begin{tabular}{|c|c|c|c|c|c|}
\hline & \multirow{2}{*}{$\begin{array}{c}\begin{array}{c}\text { Onshore(?) } \\
\text { deposit }\end{array} \\
8\end{array}$} & \multirow{2}{*}{$\begin{array}{c}\begin{array}{c}\text { Near- } \\
\text { shore } \\
\text { deposit }\end{array} \\
9\end{array}$} & \multicolumn{3}{|c|}{ Offshore deposits } \\
\hline & & & 10 & 11 & 12 \\
\hline 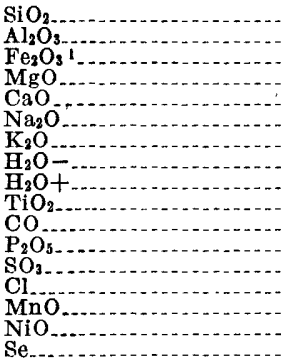 & $\begin{array}{r}49.7 \\
10.2 \\
3.6 \\
2.9 \\
13.8 \\
.9 \\
1.4 \\
1.2 \\
3.3 \\
.6 \\
11.4 \\
.2 \\
.2 \\
.2 \\
.1 \\
0\end{array}$ & $\begin{array}{r}50.1 \\
5.3 \\
2.3 \\
4.5 \\
16.7 \\
.4 \\
1.4 \\
.2 \\
1.3 \\
.3 \\
16.4 \\
.2 \\
.2 \\
.2 \\
.1 \\
0 \\
0\end{array}$ & \begin{tabular}{r|}
52.8 \\
11.1 \\
3.5 \\
2.2 \\
12.1 \\
.4 \\
1.7 \\
2.1 \\
3.2 \\
.6 \\
9.2 \\
.3 \\
$<.2$ \\
$<.1$ \\
.1 \\
0
\end{tabular} & $\begin{array}{r}45.1 \\
7.7 \\
3.0 \\
3.8 \\
17.0 \\
.8 \\
1.7 \\
1.5 \\
2.5 \\
.5 \\
15.4 \\
.3 \\
.3 \\
<.1 \\
.1 \\
0\end{array}$ & $\begin{array}{r}46.8 \\
7.7 \\
2.7 \\
3.1 \\
15.8 \\
1.5 \\
2.0 \\
2.5 \\
2.2 \\
.5 \\
13.6 \\
.2 \\
.5 \\
.6 \\
<.1 \\
0 \\
0\end{array}$ \\
\hline & 99.7 & 99.6 & 99.5 & 99.6 & 99.7 \\
\hline
\end{tabular}

1 Ferrous iron not determined because of the presence of organic matter.

8. On Highland Bench, east quarter corner, sec. 7, T. 5 S., R. 2 E. Sample 42 inches below surface.

9. Center of NE1/4 sec. 18, T. 5 S., R. 2 E

10. 40 inches below surface. Center of west side SW1/4 sec. $20, T, 5 \mathrm{~S}$, , R. $2 \mathrm{E}$.

11. 40 inches below surface. Center of west side, sec. 29 , T. 5 S., R. $2 \mathrm{E}$.

12. Center of south line, sec. 31, T. 5 S., R. 2 E; 36 inches below surface.

TABLE 6.-Complete analyses of silt and clay from Alpine formation

[Analyses by Norman Davidson, chemist, U. S. Geological Survey]

\begin{tabular}{|c|c|c|c|c|c|c|}
\hline & \multicolumn{2}{|c|}{$\begin{array}{l}\text { Near-shore } \\
\text { deposits }\end{array}$} & \multicolumn{4}{|c|}{ Offshore deposits } \\
\hline & 13 & 14 & 15 & 16 & 17 & 18 \\
\hline $\begin{array}{l}\mathrm{SiO}_{2} \\
\mathrm{Al}_{2} \mathrm{O}_{3} \\
\mathrm{Fe}_{2} \mathrm{O}_{2} \mathrm{1} \\
\mathrm{MgO} \\
\mathrm{CaO} \\
\mathrm{Na}_{2} \mathrm{O} \\
\mathrm{K}_{2} \mathrm{O} \\
\mathrm{H}_{2} \mathrm{O}- \\
\mathrm{H}_{2} \mathrm{O}+ \\
\mathrm{TiO}_{2} \\
\mathrm{CO}_{2} \\
\mathrm{P}_{2} \mathrm{O}_{3} \\
\mathrm{SO} \\
\mathrm{Cl} \\
\mathrm{MnO} \\
\mathrm{NiO} \\
\mathrm{Se}\end{array}$ & $\begin{array}{r}41.9 \\
10.7 \\
2.3 \\
5.1 \\
16.3 \\
.7 \\
1.9 \\
1.8 \\
2.3 \\
.4 \\
16.3 \\
.2 \\
.1 \\
.2 \\
.1 \\
0 \\
0\end{array}$ & $\begin{array}{r}43.4 \\
10.4 \\
3.2 \\
4.5 \\
15.7 \\
1.2 \\
2.1 \\
1.1 \\
2.6 \\
.5 \\
15.0 \\
.3 \\
.1 \\
.4 \\
.1 \\
0 \\
0\end{array}$ & $\begin{array}{r}45.2 \\
11.2 \\
3.5 \\
3.8 \\
15.0 \\
.9 \\
2.3 \\
1.8 \\
2.6 \\
.5 \\
13.2 \\
.2 \\
.4 \\
.1 \\
.1 \\
0\end{array}$ & $\begin{array}{r}47.7 \\
11.5 \\
3.6 \\
3.5 \\
13.9 \\
.8 \\
1.3 \\
1.7 \\
2.9 \\
.5 \\
12.1 \\
.3 \\
.1 \\
.1 \\
.1 \\
0 \\
0\end{array}$ & $\begin{array}{r}53.6 \\
10.0 \\
3.1 \\
3.3 \\
12.3 \\
1.5 \\
1.5 \\
1.3 \\
1.6 \\
.5 \\
10.8 \\
.2 \\
.4 \\
.1 \\
<.1 \\
0 \\
0 \\
\end{array}$ & $\begin{array}{r}53.7 \\
11.1 \\
3.9 \\
3.2 \\
10.4 \\
1.3 \\
1.7 \\
3.1 \\
2.0 \\
.5 \\
9.0 \\
.2 \\
.3 \\
.1 \\
.1 \\
0 \\
0\end{array}$ \\
\hline Total & 100.3 & 100.6 & 100.8 & 100.1 & 100.2 & 100.6 \\
\hline
\end{tabular}

1 Ferrous iron not determined because of the presence of organic matter.

13. Hill south of Alpine in the SW1/4NE1/4 sec. 25, T. $4 \mathrm{~S}$., R. $1 \mathrm{E}$.

14. Canal bank north of Dry Creek; SE1/4SE1/4 sec. 27 , T. 4 S., R. 1 E.

15. Lower part of formation in Dades Gulch; SE1/4 sec. $34, \mathrm{~T} .4 \mathrm{~S}$., R. $1 \mathrm{E}$.

16. Upper part of formation in Dades Gulch; $S E 1 / 4 \mathrm{sec}$. $34, \mathrm{~T}$.

18. Excavation for abutment for Jordan River bridge, Lehi-Cedar Fort road. See also table showing traces of metals. 
TABLE 7.-Analyses of water-soluble salts in Alpine and Provo formations, in percent

[Analyses by Margaret D. Foster, chemist, U. S. Geological Survey]

\begin{tabular}{|c|c|c|c|c|c|c|c|c|c|c|c|c|c|c|c|c|c|c|}
\hline & \multicolumn{12}{|c|}{ Provo formation } & \multicolumn{6}{|c|}{ Alpine formation } \\
\hline & \multicolumn{7}{|c|}{ Northwest of Dry Creek } & \multicolumn{5}{|c|}{ Southeast of American Fork River } & \multirow{2}{*}{\multicolumn{2}{|c|}{$\begin{array}{c}\text { Near-shore } \\
\text { deposits }\end{array}$}} & \multirow{2}{*}{\multicolumn{4}{|c|}{ Offshore deposits }} \\
\hline & \multicolumn{3}{|c|}{$\begin{array}{l}\text { Near-shore } \\
\text { deposits }\end{array}$} & \multicolumn{4}{|c|}{ Offshore deposits } & \multirow{2}{*}{$\begin{array}{c}\begin{array}{c}\text { Onshore } \\
\text { deposits }\end{array} \\
8\end{array}$} & \multirow{2}{*}{$\begin{array}{c}\begin{array}{c}\text { Near-shore } \\
\text { deposits }\end{array} \\
9\end{array}$} & \multicolumn{3}{|c|}{$\begin{array}{l}\text { Offshore } \\
\text { deposits }\end{array}$} & & & & & & \\
\hline & 1 & 2 & 3 & 4 & 5 & 6 & 7 & & & 10 & 11 & 12 & 13 & 14 & 15 & 16 & 17 & 18 \\
\hline $\begin{array}{l}\mathrm{CaO} \\
\mathrm{MgO} \\
\mathrm{Na}_{2} \mathrm{O} \\
\mathrm{K}_{2} \mathrm{O} \\
\mathrm{CO}_{2} \\
\mathrm{SO} \mathrm{O}_{3} \\
\mathrm{Cl}\end{array}$ & $\begin{array}{r}0.01 \\
.02 \\
.63 \\
.04 \\
.14 \\
.25 \\
.77\end{array}$ & $\begin{array}{l}0.01 \\
.01 \\
.17 \\
.03 \\
.25 \\
.04 \\
.01\end{array}$ & $\begin{array}{r}0.01 \\
.01 \\
.05 \\
.03 \\
.17 \\
.08 \\
.01\end{array}$ & $\begin{array}{r}0.01 \\
.01 \\
.30 \\
.01 \\
.24 \\
.25 \\
.18\end{array}$ & $\begin{array}{r}0.17 \\
.03 \\
.58 \\
.03 \\
.11 \\
.72 \\
.38\end{array}$ & $\begin{array}{l}0.01 \\
.01 \\
.49 \\
.04 \\
.13 \\
.26 \\
.36\end{array}$ & $\begin{array}{r}0.05 \\
.03 \\
.37 \\
.02 \\
.13 \\
.21 \\
.67\end{array}$ & $\begin{array}{r}0.05 \\
.01 \\
.17 \\
.01 \\
.14 \\
.07 \\
.20\end{array}$ & $\begin{array}{l}0.01 \\
.02 \\
.28 \\
.01 \\
.25 \\
.01 \\
.01\end{array}$ & $\begin{array}{r}0.06 \\
.06 \\
.04 \\
.03 \\
.32 \\
.01 \\
.01\end{array}$ & $\begin{array}{l}0.01 \\
.04 \\
1.02 \\
.06 \\
.19 \\
.51 \\
.01\end{array}$ & $\begin{array}{r}0.06 \\
.04 \\
.05 \\
.03 \\
.22 \\
.06 \\
.61\end{array}$ & $\begin{array}{c}0.01 \\
.03 \\
.25 \\
.03 \\
.22 \\
.04 \\
.12\end{array}$ & $\begin{array}{l}0.05 \\
.02 \\
.05 \\
.04 \\
.14 \\
.04 \\
.45\end{array}$ & $\begin{array}{r}0.05 \\
.02 \\
.03 \\
.03 \\
.17 \\
.05 \\
.01\end{array}$ & $\begin{array}{l}0.03 \\
.03 \\
.07 \\
.03 \\
.20 \\
.07 \\
.05\end{array}$ & $\begin{array}{l}0.01 \\
.02 \\
.04 \\
.03 \\
.16 \\
.02 \\
.02\end{array}$ & $\begin{array}{r}0.01 \\
.03 \\
.04 \\
.05 \\
.19 \\
.02 \\
.01\end{array}$ \\
\hline Total ....... & 1.86 & 0.52 & 0.36 & 1.00 & 2.02 & 1.30 & 1.48 & 0.65 & 0.59 & 0.53 & 1.84 & 1.07 & 0.70 & 0.79 & 0.36 & 0.48 & 0.30 & 0.35 \\
\hline
\end{tabular}

TABLE 8.-Analyses of water from Utah Lake

[From Olarke, F. W., Data of geochemistry: U. S. Geol. Survey Bull. 695, p. 154, 1920]

\begin{tabular}{|c|c|c|c|c|c|}
\hline & $\mathbf{A}$ & B & $\mathrm{c}$ & D & $\mathbf{E}$ \\
\hline $\begin{array}{l}\mathrm{Cl}_{-.} \\
\mathrm{SO}_{4-} \\
\mathrm{CO}_{3-} \\
\mathrm{Li}_{\ldots}\end{array}$ & $\begin{array}{r}4.04 \\
42.68 \\
19.88\end{array}$ & $\begin{array}{r}35.48 \\
26.53 \\
2.66\end{array}$ & $\begin{array}{l}26.23 \\
28.49 \\
10.23\end{array}$ & $\begin{array}{l}24.75 \\
28.25 \\
12.35\end{array}$ & $\begin{array}{r}26.87 \\
\text { 30. } 14 \\
8.48\end{array}$ \\
\hline $\begin{array}{l}\mathrm{Ll} \\
\mathrm{Na} \\
\mathrm{K} \\
\mathrm{Ca}\end{array}$ & $\left\{\begin{array}{r}5.81 \\
18.24\end{array}\right.$ & $\begin{array}{r}26.20 \\
7.58\end{array}$ & $\left\{\begin{array}{r}19.28 \\
2.34 \\
6.25\end{array}\right.$ & $\begin{array}{r}.06 \\
18.19 \\
2.17 \\
5.90\end{array}$ & $\begin{array}{r}\text { 18. } 34 \\
1.75 \\
5.34\end{array}$ \\
\hline $\begin{array}{l}\mathbf{S r} \\
\mathbf{M g}_{-} \\
\mathrm{SiO}_{2 \ldots}\end{array}$ & $\begin{array}{l}\text { 6. } 08 \\
\text { 3. } 27\end{array}$ & 1.55 & 7.18 & $\begin{array}{r}\text { r. } 15 \\
\text { 6. } 18 \\
\text { 2. } 00\end{array}$ & $\begin{array}{l}6.85 \\
2.23\end{array}$ \\
\hline Total & 100.00 & 100.00 & 100.00 & 100.00 & 100.00 \\
\hline $\begin{array}{l}\text { Salinity, parts per } \\
\text { million }\end{array}$ & 306 & 892 & 1,281 & 1,165 & 1,254 \\
\hline
\end{tabular}

A. By F. W. Olarke, U. S. Geol. Survey Bull. 9, 1884, p. 20.

B. By F. K. Oameron, 1899

D. Mean of three analyses by A. Seidell, 1904. Samples taken in May.

E. By B. E. Brown, 1904. Collected August 31. For analyses B, C, D, and $\mathbf{E}$ to terms of normal carbonates.

\section{COMPARISONS BETWEEN GIMLLAR DEPOSITS FROM DIFFHRENT GOURCES}

In order to compare similar and contemporaneous lake deposits that seem to have had different sources, one set of samples was collected from near-shore and offshore silt and clay of the Provo formation lying north of Dry Creek, which contributed considerable granitic material to the lake, and another similar set was collected from the formation southeast of American Fork River where the drainage tributary to the valley is almost entirely from limestone and quartzite. As shown in the following table these two parts of the Provo formation are very similar in composition.

The differences are surprisingly slight. It seems reasonable to infer that the rate of settling of sediment in the offshore and deep-water parts of the lake, during the Provo stage at least, was sufficiently slow to permit rather thorough mixing of those sediments across an area of at least 75 square miles on the lake bottom.
TABLE 9.-Proportions of certain constituents in the Provo formation in different parts of the valley

\begin{tabular}{|c|c|c|c|c|}
\hline & \multicolumn{2}{|c|}{$\begin{array}{c}\text { Ares northwest of Dry } \\
\text { Creek }\end{array}$} & \multicolumn{2}{|c|}{$\begin{array}{l}\text { Area southeast of Amer- } \\
\text { ican Fork River }\end{array}$} \\
\hline & $\mathbf{A}$ & B & C & D \\
\hline $\begin{array}{l}\mathrm{MgO} \\
\mathrm{CaO}^{\mathrm{Na}} \\
\mathrm{Na}_{2} \mathrm{O}_{2} \\
\mathrm{~K}_{2} \mathrm{O}_{2} \\
\mathrm{CO}_{2} \\
\mathrm{P}_{2} \mathrm{O}_{5} \\
\mathrm{SO}_{3} \\
\mathrm{Cl}_{3}\end{array}$ & $\begin{array}{r}9.0 \\
40.5 \\
5.5 \\
5.3 \\
34.6 \\
.5 \\
1.8 \\
2.8\end{array}$ & $\begin{aligned} & \text { 10. } 0 \\
& 43 . 3 \\
& 3.0 \\
& 6.1 \\
& 35.7 \\
& .6 \\
& 1.0 \\
& .3\end{aligned}$ & $\begin{aligned} 9.5 \\
43.1 \\
2.2 \\
4.7 \\
38.3 \\
.7 \\
.8 \\
.7\end{aligned}$ & $\begin{aligned} & 9 . 7 \\
& 44 . 1 \\
& 1 . 4 \\
& 4 . 9 \\
& 38 . 3 \\
& .7 \\
& .6 \\
& . 3\end{aligned}$ \\
\hline Total & 100. 0 & 100.0 & 100. 0 & 100. 0 \\
\hline
\end{tabular}

A. Data from table 4 recalculated to 100 percent from the averages of 7 complete analyses of near-shore and offshore silt and clay deposits.

B. Data from table 4 recalculated to 100 percent on water-soluble-salt-free basis. C. Data from table 5 recalculated to 100 percent from the averages of 4 complete analyses of near-shore and offshore silt and clay deposits.

D. Data from table 5 recalculated to 100 percent on water-soluble-salt-free basis.

The two parts of the Provo formation also are similar with respect to the proportions of the various watersoluble salts, as shown in the following table.

TABLE 10.-Proportions of water-soluble salts in the Provo formation in different parts of the basin

\begin{tabular}{|c|c|c|}
\hline & $\begin{array}{l}\text { Area north- } \\
\text { west of Dry } \\
\text { Creek } \\
\text { A }\end{array}$ & $\begin{array}{l}\text { Area south- } \\
\text { east of Amer- } \\
\text { ican Fork } \\
\text { River } \\
\text { B }\end{array}$ \\
\hline $\begin{array}{l}\mathrm{MgO} \\
\mathrm{CaO} \\
\mathrm{Na}_{2} \mathrm{O} \\
\mathrm{K}_{2} \mathrm{O} \\
\mathrm{CO}_{2} \\
\mathrm{SO}_{3}\end{array}$ & $\begin{array}{r}2 \\
3 \\
29 \\
3 \\
21 \\
17 \\
25\end{array}$ & $\begin{array}{r}5 \\
5 \\
28 \\
3 \\
31 \\
10 \\
18\end{array}$ \\
\hline Total & 100 & 100 \\
\hline $\begin{array}{l}\text { Average total content of the water- } \\
\text { soluble salts (percent) }\end{array}$ & 1. 22 & 0.94 \\
\hline
\end{tabular}

A. Data from table 7 recalculated to 100 percent from the averages of 7 analyses of

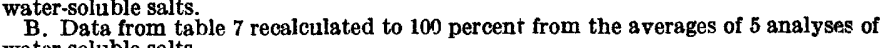
water-soluble salts. 
COMPARISONS BETWEFN GIMTLAR DEPOBITS OF DIFFERENT AGE

Those facies of the Alpine and Provo formations that are composed chiefly of silt and clay and that seem to have had a common source are similar in composition, and especially so when allowance is made for their differing contents of water-soluble salts. This comparison is illustrated in the following table.

TABLE 11.-Proportions of certain constituents in lake-bottom deposits of parts of Provo and Alpine formations that had a common source

\begin{tabular}{|c|c|c|c|c|}
\hline & \multicolumn{2}{|c|}{$\begin{array}{l}\text { Provo formation northwest } \\
\text { of Dry Creek }\end{array}$} & \multicolumn{2}{|c|}{$\begin{array}{l}\text { Alpine formation along Dry } \\
\text { Creek }\end{array}$} \\
\hline & A & B & C & D \\
\hline $\begin{array}{l}\mathrm{MgO} \\
\mathrm{CaO} \\
\mathrm{Na}_{2} \mathrm{O} \\
\mathrm{K}_{2} \mathrm{O}_{2} \\
\mathrm{CO}_{2} \\
\mathrm{P}_{2} \mathrm{O}_{5} \\
\mathrm{SO}_{3} \\
\mathrm{Cl}_{3}\end{array}$ & $\begin{array}{r}9.0 \\
40.5 \\
5.5 \\
5.3 \\
34.6 \\
.5 \\
1.8 \\
2.8\end{array}$ & $\begin{array}{r}\text { 10. } 0 \\
43.3 \\
3.0 \\
6.1 \\
35.7 \\
.6 \\
1.0 \\
.3\end{array}$ & $\begin{array}{r}11.4 \\
39.9 \\
3.1 \\
5.4 \\
38.1 \\
.8 \\
.3 \\
1.0\end{array}$ & $\begin{array}{r}11.1 \\
41.8 \\
3.0 \\
5.4 \\
37.2 \\
.6 \\
.6 \\
.3\end{array}$ \\
\hline Total & 100. 0 & 100. 0 & 100.0 & 100.0 \\
\hline
\end{tabular}

A. Data from table 4 recalculated to 100 percent from the averages of 7 complete analyses.

B. Data from table 4 recalculated to 100 percent on water-soluble-salt-free basis.
C. Data from table 6 recalculated to 100 percent from the averages of 6 complete analyses.

Data from table 6 recalculated to 100 percent on water-soluble-salt-free basis.

From these data it might be concluded that the environments under which the sediments of the two formations were derived and deposited were not sufficiently different to cause much difference in their chemical composition. With respect to water-soluble salts, however, the two formations are less alike, for the average salt content of the Alpine is less than half that of the Provo. The salt content of the two formations is inversely proportional to the volumes of water that were in the lake during the maxima of the two ttages, so probably the salt content of the water during she Provo stage was a few times greater than during the Alpine stage. However, the proportions of the different constitutents are somewhat different, as brought out in the following table.

TABLE 12.-Proportions of water-soluble salts in the Provo and Alpine formations

\begin{tabular}{|c|c|c|}
\hline & $\begin{array}{c}\text { Provo } \\
\text { formation }\end{array}$ & $\begin{array}{c}\text { Alpine } \\
\text { formation }\end{array}$ \\
\hline & A & B \\
\hline $\begin{array}{l}\mathrm{MgO} \\
\mathrm{CaO} \\
\mathrm{Na}_{2} \mathrm{O} \\
\mathrm{K}_{2} \mathrm{O}_{2} \\
\mathrm{CO}_{2} \\
\mathrm{SO}_{3}\end{array}$ & $\begin{array}{r}3 \\
4 \\
30 \\
3 \\
25 \\
14 \\
21\end{array}$ & $\begin{array}{r}6 \\
5 \\
15 \\
8 \\
41 \\
9 \\
16\end{array}$ \\
\hline Total & 100 & 100 \\
\hline $\begin{array}{l}\text { Average total content of the water- } \\
\text { soluble salts (percent) }\end{array}$ & 1. 10 & 0. 49 \\
\hline
\end{tabular}

A. Data from table 7 recalculated to 100 percent from the averages of 12 analyses

B. Data from table 7 recalculated to 100 percent from the averages of 6 analyses.
Probably the most striking difference in the proportions of the various salts in the two formations is the ratio of $\mathrm{Na}_{2} \mathrm{O}$ to $\mathrm{K}_{2} \mathrm{O}$, which averages about 2 to 1 in the Alpine and about 10 to 1 in the Provo. The ratio is about 10 to 1 in the Utah Lake waters also. (See table 8.)

The salt content of the Alpine formation is more like that part of the Provo formation southeast of American Fork than like the Provo northwest of Dry Creek, despite the fact that the Alpine formation samples were taken from along Dry Creek. Perhaps the Alpine formation in that part of the area is composed dominantly of sediments derived from American Fork River. Perhaps also the sediments from different sources were less well mixed in the Alpine formation than in the Provo formation.

\section{COMPARISONG BETWEEN NEAR-SHORE AND OFFSHORE} DEPOSITE

Additional differences between the Alpine and Provo formations appear by comparing the compositions of the near-shore and offshore deposits of silt and clay. The distribution of water-soluble salts with respect to proximity to the old shores is exactly opposite in the two formations.

In the Alpine formation the total of the water-soluble salts increases shoreward; the salt content of the Provo formation decreases shoreward, as shown in the following tables:

TABLE 13.-Distribution of water-soluble salts in samples from silt and clay facies of the Alpine formation

[Proportion of certain constituents to total water-soluble salts (percent). Data from

\begin{tabular}{|c|c|c|c|c|c|c|c|}
\hline & \multicolumn{2}{|c|}{$\begin{array}{l}\text { Near-shore } \\
\text { deposits }\end{array}$} & \multicolumn{2}{|c|}{$\begin{array}{l}\text { Offishore } \\
\text { deposits }\end{array}$} & \multicolumn{2}{|c|}{$\begin{array}{c}\text { Deep-water } \\
\text { deposits }\end{array}$} & \multirow{2}{*}{$\begin{array}{l}\text { A ver- } \\
\text { age }\end{array}$} \\
\hline & 13 & 14 & 15 & 16 & 17 & 18 & \\
\hline $\begin{array}{l}\mathrm{MgO} \\
\mathrm{CaO} \\
\mathrm{Na} 2 \\
\mathrm{~K}_{2} \mathrm{O}_{2}\end{array}$ & $\begin{array}{r}4 \\
1 \\
36 \\
4 \\
32 \\
6 \\
17\end{array}$ & $\begin{array}{r}3 \\
6 \\
6 \\
5 \\
18 \\
5 \\
57 \\
\end{array}$ & $\begin{array}{r}6 \\
14 \\
8 \\
8 \\
47 \\
14 \\
3\end{array}$ & $\begin{array}{r}6 \\
6 \\
15 \\
6 \\
42 \\
15 \\
10 \\
\end{array}$ & $\begin{array}{r}7 \\
3 \\
13 \\
10 \\
53 \\
7 \\
7\end{array}$ & $\begin{array}{r}9 \\
3 \\
11 \\
14 \\
54 \\
6 \\
3 \\
\end{array}$ & $\begin{array}{r}6 \\
5 \\
15 \\
8 \\
41 \\
9 \\
16 \\
\end{array}$ \\
\hline Total. & 100 & 100 & 100 & 100 & 100 & 100 & 100 \\
\hline $\begin{array}{l}\text { otal content of water-soluble } \\
\text { salts (percent)e }\end{array}$ & 0.70 & 0.79 & 0.36 & 0.48 & 0.30 & 0.35 & 0.49 \\
\hline
\end{tabular}

TABLE 14.-Distribution of water-soluble salts in samples from silt and clay facies of the Provo formation

[Proportion of certain constituents to total water-soluble salts (percent)] Sediments from area north west of Dry Creek

\begin{tabular}{|c|c|c|c|c|c|c|c|c|}
\hline & \multicolumn{3}{|c|}{$\begin{array}{c}\text { Near-shore } \\
\text { deposits }\end{array}$} & \multicolumn{4}{|c|}{ Deep-water deposits } & \multirow{2}{*}{$\begin{array}{c}\text { Aver- } \\
\text { age }\end{array}$} \\
\hline & 1 & 2 & 3 & 4 & 5 & B & 7 & \\
\hline $\begin{array}{l}\mathrm{MgO} \\
\mathrm{CaO} \\
\mathrm{Na}_{2} \mathrm{O} \\
\mathrm{K}_{2} \mathrm{O} \\
\mathrm{CO}_{2} \\
\mathrm{gO}_{3} \\
\mathrm{Cl}\end{array}$ & $\begin{array}{r}1 \\
-34 \\
2 \\
8 \\
13 \\
41\end{array}$ & $\begin{array}{r}<2 \\
<2 \\
63 \\
6 \\
48 \\
8 \\
<2\end{array}$ & $\begin{array}{r}<3 \\
<3 \\
14 \\
9 \\
47 \\
<3 \\
22\end{array}$ & $\begin{array}{r}1 \\
1 \\
30 \\
1 \\
24 \\
25 \\
18\end{array}$ & $\begin{array}{r}<1 \\
9 \\
29 \\
1 \\
5 \\
36 \\
10\end{array}$ & $\begin{array}{r}<1 \\
>1 \\
38 \\
3 \\
10 \\
20 \\
28\end{array}$ & $\begin{array}{r}2 \\
<3 \\
25 \\
<1 \\
9 \\
14 \\
45\end{array}$ & $\begin{array}{r}2 \\
3 \\
29 \\
3 \\
21 \\
17 \\
25\end{array}$ \\
\hline Total... & 99 & 100 & 100 & 100 & 100 & 100 & 100 & 100 \\
\hline $\begin{array}{l}\text { Total content of water-solu- } \\
\text { ble salts. }\end{array}$ & 1.86 & 0.52 & 0.36 & 1.00 & 2.02 & 1.30 & 1.48 & 1.22 \\
\hline
\end{tabular}


TABLE 14.-Distribution of water-soluble salts in samples from silt and clay facies of the Provo formation-Continued

Sediments from area southeast of American Fork River

\begin{tabular}{|c|c|c|c|c|c|c|}
\hline & \multirow{2}{*}{$\begin{array}{c}\begin{array}{c}\text { Onshore } \\
\text { deposits }\end{array} \\
8\end{array}$} & \multirow{2}{*}{$\begin{array}{c}\begin{array}{c}\text { Offshore } \\
\text { deposits }\end{array} \\
9\end{array}$} & \multicolumn{3}{|c|}{ Deep-water deposits } & \multirow{2}{*}{$\begin{array}{l}\text { Aver- } \\
\text { age }\end{array}$} \\
\hline & & & 10 & 11 & 12 & \\
\hline $\begin{array}{l}\mathrm{MgO} \\
\mathrm{CaO} \\
\mathrm{Na}_{2} \mathrm{O} \\
\mathrm{K}_{2} \mathrm{O}_{2} \\
\mathrm{CO}_{2} \\
\mathrm{SO}_{3}\end{array}$ & $\begin{array}{r}2 \\
7 \\
26 \\
2 \\
22 \\
11 \\
30\end{array}$ & $\begin{array}{r}4 \\
<2 \\
47 \\
<2 \\
42 \\
<2 \\
<2\end{array}$ & $\begin{array}{r}11 \\
11 \\
8 \\
6 \\
60 \\
2 \\
2\end{array}$ & $\begin{array}{r}2 \\
1 \\
55(?) \\
3 \\
10 \\
28 \\
1\end{array}$ & $\begin{array}{r}4 \\
6 \\
5 \\
3 \\
20 \\
6 \\
56\end{array}$ & $\begin{array}{r}5 \\
5 \\
28 \\
3 \\
31 \\
10 \\
18\end{array}$ \\
\hline Total......... & 100 & 100 & 100 & 100 & 100 & 100 \\
\hline $\begin{array}{c}\text { Total content of water- } \\
\text { soluble salts.... }\end{array}$ & 0.65 & 0.59 & 0.53 & 1.84 & 1.07 & 0.94 \\
\hline
\end{tabular}

Also brought out by these data is the fact that in the Alpine formation the proportion of chlorides to total salts is greatest in the near-shore deposits; least in the deep-water deposits. The proportion of carbonate is greatest in the deep-water and least in the nearshoredeposits. Sulfate forms the greatest proportion of the total in an intermediate zone. As can be seen from the tables the proportions of these cations in the Provo is quite different from those in the Alpine.

The distribution of salts in the Alpine formation is suggestive of the conditions recorded at Sevier Lake (Gilbert, 1890, p. 226) where sulfate is deposited in the middle of the basin while chloride is deposited chiefly at the margin.

\section{UTAF LAKE}

Table 8 gives some analyses of the water of Utah Lake that were made between 1883 and 1904 . Clarke (1924, p. 159) states that in the 20-year period represented by the samples the lake "has undergone a thorough transformation, and its salinity has more than quadrupled. From fresh water of the sulfate type it has become distinctly saline ***." This change is attributed to artificial changes in the water supply, control of discharge from the lake, and irrigation.

Comparing the salt content of Utah Lake since 1900 with that of the Provo formation it should be noted that in each case the calcium-magnesium ratio is about $1: 1$ and the sodium-potassium ratio is about $10: 1$. The proportions of sulfate, chloride, and carbonate, however, are reversed. In Utah Lake $\mathrm{SO}_{3}>\mathrm{Cl}>\mathrm{CO}_{3}$; in the Provo formation $\mathrm{CO}_{3}>\mathrm{Cl}>\mathrm{SO}_{3}$.

\section{TRACES OF HeAVY METALS}

Traces of heavy metals in the lake deposits were determined approximately by colorometric tests using dithizone. The results are given in table 15 .

The sediments sampled were derived from American Fork River canyon. The tests suggest that the maximum concentration of heavy metals is in the fine-
TABLE 15.-Traces of heavy metals in Provo and Alpine formations (in parts per million)

[Semiquantitative colorometric tests by Lyman Huff and Hy Almond, U. S. Geological Survey]

\begin{tabular}{|c|c|c|c|c|c|c|c|}
\hline & \multirow{2}{*}{$\frac{\begin{array}{c}\text { Onshore } \\
\text { deposit }\end{array}}{\mathbf{A}}$} & \multicolumn{2}{|c|}{ Near-shore deposit } & \multicolumn{4}{|c|}{ Offshore deposit } \\
\hline & & B & $\mathrm{C}$ & $\mathrm{D}$ & $\mathbf{E}$ & $\mathbf{F}$ & $G$ \\
\hline $\begin{array}{l}\text { Total heavy metals } \\
Z_{n} \\
\text { Pb }\end{array}$ & $\begin{array}{r}100 \\
80 \\
25\end{array}$ & $\begin{array}{r}25 \\
35 \\
\text { Not run }\end{array}$ & $\begin{array}{r}25 \\
35 \\
5\end{array}$ & $\begin{array}{l}85 \\
55 \\
10\end{array}$ & $\begin{array}{l}90 \\
80 \\
15\end{array}$ & $\begin{array}{l}90 \\
60 \\
10\end{array}$ & $\begin{array}{r}100 \\
80 \\
20\end{array}$ \\
\hline
\end{tabular}

1 As a result of heavy-metals tests.

A. Gravel and silt, Provo formation; grab sample from wall of aqueduct in the NE1/4sec. 36, T. 4 S., R. 1 E.

B. Clean gravel, Provo formation; grab sample gravel pit in the NW14 sec. 18, T. 5 S., R. $2 \mathrm{E}$.

C. Clean sand; same locality as $B$

D. Clay, Provo formation; NE1/4 sec. 22, T. 5 S., R. 1 E. Grab sample about 6 inches below surface.

E. Clay, Provo formation, SE14 sec. 20, T. 5 S., R. 1 E. Grab sample about 12 inches below surface.

F. Clay, Provo formation, from excavation for bridge abutment. NW1/4 sec. 13,

T. 5 S., R. 1 W.
G. Clay, Alpine formation; same locality as F.

grained sediments and that the proportion of zinc to lead, which averages about $5: 1$, is fairly constant between the coarse- and the fine-textured facies.

\section{SALINITY OF LAKE BONNEVILLE}

Almost certainly Lake Bonneville became increasingly saline as its waters diminished in volume, but the problem of changes in salinity is complicated by the fact that shrinkage of the lake waters was due only partly to dessication. The fall of the lake from the Bonneville stage to the Provo stage, for example, apparently was due to overflow and must have occurred quickly. The salinity at these two stages, therefore, probably was about the same. The available data still are not sufficiently complete to reconstruct that part of the geologic history represented by the break between the Alpine and the younger formations in the Lake Bonneville group. After the Provo stage the lake level fell very gradually by dessication, and the salinity of the lake waters must have increased rather steadily. Even this phase of the problem, however, is complicated by the fact that Utah Valley was a bay that almost, if not altogether, closed as the lake receded from the Provo to the Stansbury level. Moreover, after Lake Bonneville shrank to the Stansbury level, Utah Valley drained into Salt Lake Valley by way of Jordan River and this change must have caused Utah Lake to become less saline.

We can be reasonably sure that the salt content of the Lake Bonneville waters in the bay represented by Utah Valley was well below the saturation point for quiet cool water because no beds of saline precipitates occur in the offshore deposits. During the Bonneville and Provo stages calcium carbonate was precipitated in some nearshore deposits at headlands, but this precipitation seems to have resulted from very local 
conditions that were not generally prevalent, perhaps because of aeration by surf action or perhaps because of biochemical action.

Part of the salts that occur in the offshore deposits of the Lake Bonneville group may have resulted from reactions between the silt and clay particles with the saline solution through which they settled. A considerable part, however, must have been contained in the water that saturated the layers of mud on the lake bottom; when the lake waters receded from such a layer there would be left a mud containing saline water whose salts would be precipitated as the mud became dry.

The high-level and near-shore deposits in the Alpine formation, where this condition most likely prevailed, contain 0.75 percent water-soluble salts. The salinity of the water during the Alpine stage, therefore, may have been of the order of several thousand parts per million.

The beds of the Alpine formation in the interior of the valley on the other hand contain as little as 0.3 percent water-soluble salts but these beds represent muds that were compacted by burial under other lake bottom sediments. They would have lost much of their water and its contained salt before final drying. Such reasoning contains many uncertainties but the probabilities seem to favor the higher rather than the lower figure as approximating the salinity of the lake at that stage.

Those deposits of the Provo formation that were nearest shore and first exposed as the lake shrank from the Provo level average about 0.75 percent watersoluble salts. Probably, therefore, at the beginning of the Provo stage, and probably also during the preceding Bonneville stage, the salinity was not greatly different from when the Alpine formation was deposited. But the deposits farthest from shore, which remained under water until the lake had shrunk (by dessication) practically to the level of Utah Lake, average almost 1.5 percent of water-soluble salts. This would suggest that the salinity doubled during the Provo stage, and may have been many thousands of parts per million.

Utah Lake now has a salinity of only a thousand or so parts per million, presumably a result of the freshening effect caused by Jordan River draining from the lake.

\section{Calchum Carbonate deposits}

The rocks in the mountains from which the sediments in Utah Valley were derived include considerable limestone. As would be expected, therefore, the valley's sediments are highly calcareous. The lime carbonate is finely distributed throughout all the $247743-53-4$ formations in the valley regardless of their texture, origin, or age. In addition, calcium carbonate has become concentrated locally at many places in the valley. These local concentrations are of at least four kinds, but the criteria for distinguishing them are not clear.

One kind seems to be related to surf action in Lake Bonneville. Gilbert (1890, pp. 167-169) described this kind and indicated its origin as follows:

The distribution of the tufa along each shore is independent of the nature of the subjacent terrane. The heaviest observed deposits are upon quartzite and granite at a considerable distance from calcareous rocks. The most conspicuous accumulations are upon rock in place, but this difference probably depends upon the fact that deposits upon unconsolidated material are largely interstitial. A more important peculiarity of the distribution is its relation to wave action. No deposit is found in sheltered bays; and on the open coast those points least protected from the fury of the waves seem to have received the most generous coating. These characters indicate, first, that the material did not have a local origin at the shore but was derived from the normal lake-water; second, that the surf afforded a determining condition of deposition.

Some of the most firmly cemented calcium carbonate deposits in Utah Valley are at places that were headlands in Lake Bonneville and perhaps these deposits were conditioned by surf action. Some examples are the deposits in the spits at the Point of the Mountain, both in the Provo and Bonneville formations, and a similar deposit in the Bonneville formation at the southernmost point of the Traverse Mountains in sec. 30, T. 4 S., R. 1 E.

A second kind of deposit is illustrated by the calcium carbonate in the upper part of the gravel facies in the Highland bench and Orem bench deltas. This carbonate is concentrated in a zone comprising the upper few feet of the gravel, generally in the topset beds, but these gravels are not firmly cemented. Commonly overlying the lime-rich zone is a foot or so of eolian(?) brown silt. (See p. 22.)

The lime carbonate in these gravel deposits probably was formed about the time the deltas were constructed. When the lake shore stood at the front edge of these deltas the ground-water level must have been only a few feet below their subaerial surfaces. The upper few feet of the gravel, therefore, would be subject alternately to wetting and drying, and would become the site for precipitation of calcium carbonate from the ground waters.

Still a third kind of calcium carbonate deposit is the result of spring action and occurs in part as true tufa. These deposits have been observed at several localities: in the alluvial deposits in a small southern tributary of Dry Creek at the front of the Wasatch Range; along the contact between the glacial outwash and the 
fanglomerate of the pre-Lake Bonneville deposits just south of Dry Creek in the SE1/4 sec. 12, T. 4 S., R. 1 E.; in fanglomerate of pre-Lake Bonneville deposits at the south point of the Traverse Mountains in secs. 31 and 32, T. 4 S., R. 1 E.; and along the front of the Wasatch Range just below the Bonneville level about 2 miles north of Pleasant Grove. The calcium carbonate deposit at the south point of the Traverse Mountains firmly cements angular gravel and occurs in steeply dipping banded veins of calcite. The other deposits are more or less horizontally layered tufa.

A fourth kind of lime carbonate concentration is attributable to soil processes, by which the upper layers of the soil become leached and the lime becomes deposited in the underlying layers. Throughout the area, in the Lake Bonneville group and younger formations, calcium carbonate has been leached from the upper few inches and redeposited in a zone several inches thick beneath the leached zone. The uppermost 2 or 3 inches of the leached zone does not effervesce in cold dilute hydrochloric acid; the materials below effervesce strongly. In the silty and clayey formations the redeposited lime takes the form of tiny white specks or veinlets that minutely mottle the brown soil. The mottled layer commonly is 10 or 12 inches thick. In gravelly formations the lime tends to form a coating on the pebbles. On pre-Lake Bonneville deposits locally there are remnants of an ancient and more maturely developed soil in which the lime-enriched zone may be as thick as 20 feet and locally buried under 10 feet of leached clay. (See p. 43.) These calcium carbonate deposits are the result of soil-forming processes.

Criteria for distinguishing the four forms of calcium carbonate deposits are not very satisfactory. The layered deposits of tufa and the banding in the calcite veins are distinctive, but related spring deposits that impregnate clastic sediments would be difficult to recognize unless perhaps it could be established that these lime deposits contain diagnostic traces of metals or other elements. The lime carbonate in the deposits attributed to surf action at headlands is more firmly cemented and more spottily distributed than is the carbonate attributed to a formerly high ground-water table. The lime concentrated in the substrata of ancient soils commonly is associated with distinctive concentrations of reddish-brown clay (p. 43). Feeble develop. ment below a very shallow leached layer is the most distinctive feature of the lime concentrated by postProvo soil processes. Possibly there are geochemical and minerological differences between these different kinds of lime deposits that could be developed as criteria for distinguishing them, but this phase of the problem was not studied.

\section{COMPARATIVE VOLUMES OF THE FORMATIONS}

The formations in northern Utah Valley differ in thickness and extent and obviously differ in volume. Estimating the volume of the different formations requires numerous assumptions, some of which are of doubtful validity, but the effort is probably of some value in that it reveals differences in the order of magnitude of erosion in the highlands that each valley formation represents.

Besides assuming the correctness of the correlations and positions of contacts as given in the description of the individual formations it is necessary to assume:

1. That the sediment in northern Utah Valley represents all the sediment derived from the drainage basins of the streams tributary to that part of the valley, and that it does not include material transported by streams tributary to the south half of the valley. Making this assumption probably involves no great error.

2. That half the Salt Lake formation is indigenous and reworked pyroclastic material and that the other half represents bedrock erosion during the volcanic cycle. This assumes that the pyroclastic facies of the formation were derived equally from all parts of the entire drainage basin, including the valley itself, and that the other half which represents erosion of bedrock was derived equally from all parts of the drainage basins tributary to the valley. The error introduced by this assumption probably is small compared to the error of assuming a thickness for the formation.

3. That the Pleistocene pre-Lake Bonneville deposits and the post-Provo alluvial deposits were derived equally from all parts of the stream basins tributary to the valley. No doubt the greater altitude of the Wasatch as compared to the other mountains was reflected in greater precipitation and denudation there, but the error is believed to be small compared to the error of assuming an average thickness for these deposits.

4. That Lake Bonneville group was derived very largely from the Wasatch Range and that the increment of sediment from the other and lower ranges during the lake period was comparatively little. The distribution and kinds of materials found in the lake deposits indicate that this assumption introduces no great error.

5. That a cubic foot of the valley deposits equals 0.8 cubic foot of consolidated rock in the mountains.

Provo River drains an area of about 650 square miles and apparently has drained that area since earliest Pleistocene time because chips of lava and purple quartzite, apparently derived from the headwaters, were identified in the cuttings from a well at the Geneva Steel plant down to a depth of at least 600 feet. 
American Fork River drains about 60 square miles, while Dry Creek and its tributaries above Alpine drain about 22 square miles. The total area in the Wasatch Range and mountainous areas farther east that is tributary to northern Utah Valley is only a little greater than this total of 730 square miles. About 10 square miles of the Traverse Mountains drain into Utah Valley. About 25 square miles of the Lake Mountains and other lower hills west of Utah Valley have contributed materially to sedimentation in northern Utah Valley. Northern Utah Valley itself comprises 175 square miles.

Assuming the Salt Lake formation to have an average thickness of 500 feet under the valley, its volume would be about 17.5 cubic miles. Half of this has been assumed to be derived from bedrock erosion in the areas tributary to the valley and represents erosion of 7 cubic miles of rock from an area of 745 square miles, or an average lowering of the whole tributary highland surface by about 48 feet. The other half of the Salt Lake formation, the pyroclastic facies, is assumed to include some pyroclastics deposited directly in the valley, the rest washed in from the highlands. The total volume of this unconsolidated material is about 8.75 cubic miles, which represents a layer of pyroclastics roughly 50 feet thick spread over an area of 920 square miles.

If the pre-Lake Bonneville Pleistocene deposits under the valley average 500 feet in thickness, their volume also is about 17.5 cubic miles. This represents 14 cubic miles of bedrock removed from an area of about 745 square miles, or an average denudation amounting to roughly 95 feet of bedrock.

If the Alpine formation averages 75 feet in thickness under the valley, its volume is about 2.6 cubic miles. This has been assumed to have come largely from the Wasatch Range and represents an average lowering of the bedrock surface there of about 14 feet.

The volume of the Bonneville formation is negligible.

The Provo formation aggregates about 0.5 cubic mile if its average thickness is 15 feet. This formation represents the removal of about 3 feet of bedrock from the whole surface of the tributary part of the Wasatch Range.

Post-Provo deposits probably aggregate only a tenth as much volume as the Provo formation and, therefore, represent the erosion of only a few inches of bedrock material from the whole surface of the adjoining highlands.

These estimates are more easily compared if tabulated.
Comparative volumes of the formations in northern Utah Valley and the depth of bedrock erosion represented by them

\begin{tabular}{|c|c|c|}
\hline Formation & $\begin{array}{l}\text { Estimated vol- } \\
\text { ume of material } \\
\text { eroded from the } \\
\text { bedrock of the } \\
\text { adjoining high- } \\
\text { lands (in cubic } \\
\text { miles) }\end{array}$ & $\begin{array}{l}\text { A verage amount } \\
\text { of lowering of } \\
\text { the whole surface } \\
\text { of the adjoining } \\
\text { highlands } \\
\text { (in feet) }\end{array}$ \\
\hline $\begin{array}{l}\text { Post-Provo formations. } \\
\text { Lake Bonneville group: } \\
\text { Provo formation. } \\
\text { Bonneville formation. } \\
\text { Alpine formation... }\end{array}$ & $\begin{array}{ll}\text { (1) } & \\
& 0.5 \\
& 2.6 \\
\end{array}$ & (l) \\
\hline Total, Lake Bonneville........ & 3.1 & 17 \\
\hline $\begin{array}{l}\text { Pre-Lake Bonneville Pleistocene deposits } \\
\text { Salt Lake formation (for each } 500 \text { feet of thick- } \\
\text { ness and excluding indigenous and reworked } \\
\text { pyroclastics) }\end{array}$ & 14.0 & 95 \\
\hline Total_... & 24.1 & 160 \\
\hline
\end{tabular}

${ }^{1}$ Negligible.

\section{DEPTE OF VALLEY FIIL}

Very likely there is considerable relief on the bedrock surface under the valley fill and total depth of the fill probably varies considerably from place to place.

The summits of several buried hills of Paleozoic rocks protrude through the fill near the foot of the Lake Mountains. Paleozoic rocks also are exposed at several places below the Bonneville level at the foot of the Wasatch Range and in some gullies in the fanglomerate south of the Traverse Mountains in the $\mathrm{SE} / 4$ sec. 30, T. 4 S., R. 1 E. Volcanic breccia, no doubt Tertiary and perhaps older than the Salt Lake formation, is exposed in the SW $1 / 4$ sec. 2, T. 5 S., R. 1 W. These exposures are too incomplete to suggest the pattern that might be expected in the old topography buried under the interior of the valley.

The deepest boring in the valley, the well drilled by the Geneva Steel Co. in the SE $142 \mathrm{NW} / 4$ sec. $8, \mathrm{~T}$. 6 S., R. 2 E. (A-16225), is 830 feet deep and the base of the Pleistocene assuredly is no higher than 500 feet below the surface there (fig. 5). The deep well at Cutler may have penetrated into the Salt Lake formation but none of the wells has reached Paleozoic formations.

In March 1947 the Geological Survey's airborne magnetometer was flown along seven east-west traverses that crossed the valley in Tps. 5 and $6 \mathrm{~S}$. and along a diagonal traverse roughly following the D., R. G., \& W. R. R. from Provo across the Jordan Narrows. A magnetic anomaly was detected at the Jordan Narrows but no anomalies were found in the interior of the valley. This indicates that there are no buried hills containing volcanic rocks like those in the Traverse 
Mountains within a few thousand feet of the surface of northern Utah Valley.

The fact that the Pleistocene deposits in the valley appear to thicken southward suggests that in general the depth of the valley fill increases in that direction.

\section{STRUCTURAL GEOLOGY}

Utah Valley is a structural valley bounded by late Tertiary and Quaternary faults; the valley undoubtedly is primarily the result of faulting, although folding or tilting may have contributed to the displacement.

The late Tertiary and Quaternary faults all appear to be normal faults. Those along the east side of the valley occur in a complex zone along the front of the Wasatch Range, but A. A. Baker, who has been studying and mapping that part of the Wasatch, has found parallel faults apparently belonging to the same system deep within the mountains also. The faults shown along the front of the Wasatch Range (see pl. 1) therefore represent only the westernmost of a wide set of faults which have had late Tertiary and Quaternary displacement. Very probably similar faults break the bedrock beneath Utah Valley.

The faulting that gave rise to Utah Valley probably began prior to deposition of the Salt Lake formation and has continued intermittently practically to the present time. This late Tertiary and Quaternary faulting belongs to the epoch of block faulting that affected the Basin and Range province generally. Wholly different and seemingly independent of this orogeny is the earlier so-called Laramide thrusting and folding that is so evident in the Wasatch and in the mountains of the Basin and Range province. Structural movements attributed to the Laramide orogeny seem to have occurred during most of Cretaceous and early Tertiary time. (Spieker, 1946.)

There is no single Wasatch fault. There is, rather, a wide complex fault zone in which the greatest displacements seem to be in that part of the zone bordering the mountain front. In this part of the zone most of the disturbed strata are down-dropped to the west along the faults; a few faults are down-dropped on the east side.

Paleozoic rocks are displaced many thousands of feet along these faults. The aggregate displacement on all the faults across the fault zone in front of the mountains probably is as great as the present topographic relief and may exceed it. In front of Mount Timpanogo the total displacement is probably 7,000 feet or more. Two miles north of Pleasant Grove a block of Manning Canyon shale has been faulted down about 4,000 feet.

Along several faults at the mountain front pre-Lake Bonneville Pleistocene deposits are displaced a few hundred feet. Along the same faults Paleozoic rocks are displaced many hundreds or a few thousands of feet. The Manning Canyon shale, for example, is displaced 4,000 feet along one of the faults north of Pleasant Grove but along the same fault, pre-Lake Bonneville Pleistocene deposits are displaced only about 450 feet.

The Lake Bonneville group is faulted too. At the mouth of American Fork Canyon the Bonneville formation is displaced about 60 feet. About one-half mile up Provo Canyon other gravel deposits of the Lake Bonneville group also are displaced a few tens of feet.

The older of the two moraines just above the town of Alpine is displaced about 100 feet along a fault; southward, at Boxelder Creek, the fault dies out and the displacement evidently is taken up by tilting of the Boxelder Creek fan. This fan consequently has a steeper surface than do neighboring fans and the creek has incised a deep gorge in it. The fault reappears in the Pleistocene deposits between Boxelder Creek and American Fork Canyon.

The fault pattern along the west and north sides of the valley may be similar to that along the front of the Wasatch. Pre-Lake Bonneville Pleistocene deposits are faulted but the mapping of the bedrock faults is incomplete. On the east end of the Traverse Mountains fanglomerate of pré-Lake Bonneville deposits, has been raised a few hundred feet, almost certainly because of faulting, and has been deeply dissected.

The late Tertiary Salt Lake formation is involved in faulting and is tilted about $45^{\circ}$ where it is exposed in the Jordan Narrows. It is likely that Utah Valley had already started to develop when this formation was deposited (p. 12).

The evidence in Utah Valley harmonizes with that from other parts of the Basin and Range province and indicates that the many thousands of feet of block faulting that produced the valley was the result of repeated small movements over a very long period of time. The movements probably began in middle or late Tertiary time and have continued intermittently practically to the present. Indeed, because the Wasatch front is the center for repeated mild seismic disturbances it is even possible that the mountain blocks are rising today as vigorously and violently as they ever have in the past. Ten thousand feet of displacement can form a high mountain but if that movement is distributed through a few million years only inches of displacement are required during so brief a period as the Christian era. Actually 60 feet of movement is known to have occurred since Lake Bonneville time.

The fact that the Bonneville formation at one place has been raised above its shoreline indicates that 
during the most recent movement the mountains were the active block; the mountains were raised, the valley lagged behind. Perhaps the valley was raised also, though less so than the mountains. Probably during the earlier movements too the valley block has been more passive than the mountains.

Gilbert (1890, pp. 365-373) has pointed out that the Lake Bonneville group has been slightly warped. According to his data Utah Valley has been tilted slightly southeastward.

Well data (p. 14) indicate that the formations comprising the valley fill in Utah Valley thicken southeastward and probably the bedrock surface is deeper at the south than at the north. These data, combined with those gathered by Gilbert, suggest that the southeastward tilting of Utah Valley, like the faulting, has progressed intermittently since the valley was formed.

Except for this warping or tilting, evidence of structural movements within the valley is generally lacking. The Provo formation covers most of the valley and it has not been observedly faulted or tilted. Numerous small faults break the foreset beds in the deltas but the displacement is measurable only in inches and generally is down toward the delta front. Almost certainly these breaks reflect settling rather than structural movements. An interesting feature of these breaks is the fact that they sharply separate the displaced beds even though they are unconsolidated; there is essentially no drag. Along the shore of Utah Lake, west of the Geneva Steel plant, the nearly horizontal Provo formation lies with angular unconformity on steeply tilted beds belonging to the Alpine formation. These beds of the Alpine formation commonly dip $30^{\circ}-40^{\circ} \mathrm{E}$., and in places they are severely contorted in small recumbent folds. The discordance is considerable and very likely reflects sublacustrine slippage rather than structural deformation, for contorted bedding is a rather common feature in the Alpine formation.

When a considerable part of the Lake Bonneville basin has been remapped precise levels correlated with the geological studies no doubt will reveal much information about recent diastrophic movements in the region. The valley still is mildly active seismically. (See p. 60.) How much warping can the bedrock and overlying unconsolidated deposits endure before they yield, by slipping again, and break? Neither seismologists nor geologists know the answer, but precise knowledge of the geological record and precise knowledge of minute changes in level that may be taking place today are certainly minimum essentials for determining that answer.

\section{GEOLOGICAL HISTORY}

ORIGIN AND STRUCTURAL HISTORY OF THE VALLEY

As to the origin of Utah Valley we have few facts. Probably the valley is due very largely to block faulting, by which the adjoining mountain blocks have been raised relative to the valley block. But it should be noted that geologists are unable to evaluate the degree to which folding or tilting of the blocks has contributed to or otherwise influenced the deformation.

The block faulting that formed Utah Valley and other valleys in the Basin and Range province has continued to the present time and the faulting may be continuing today as vigorously as in the past. Certainly there are many very recent fault scarps in the Province and many parts of it are seismically active. Utah Valley is no exception. The block faulting is known to have progressed intermittently at least since Pliocene time. How much earlier it started is not yet known.

Presumably the folding and thrust faulting of the Paleozoic and Mesozoic rocks in the mountains adjoining Utah Valley occurred during late Mesozoic and earliest Cenozoic time, as it did farther south in central Utah (Spieker, 1946, pp. 149-155). The block faulting by which the valley assumed the shape and proportions we see today occurred later and was superimposed on the older structures. However, until regional geological mapping is more complete than it is today, we have no way of determining to what extent the older structures have controlled the younger ones.

Gilluly (1932, pp. 40, 65-66, 85-86) has reasoned that the volcanism in the area immediately northwest of Utah Valley is late Eocene or Oligocene. These lavas have been deformed and it seems likely that their deformation was related to the deformation that developed Utah Valley, though the principal structural movements may have come later and may have differed somewhat in type from the earlier movements. For the present, little more can be done than to assume middle Tertiary time as the date when Utah Valley began to develop as a structural valley. By late Tertiary time it seems to have become a valley of appreciable size because the valley sides were sufficiently high and steep to supply boulder conglomerates to the Salt Lake formation. By early Pleistocene time the valley had developed proportions such as we see today.

Although the early history of the block faulting is obscure the later history is clear. The facts that the Paleozoic rocks are more deformed than the late Tertiary Salt Lake formation, that the Salt Lake formation is more faulted and tilted than the pre- 
Lake Bonneville Pleistocene deposits; and that the pre-Lake Bonneville deposits are more faulted than the Lake Bonneville group clearly indicate that the fault movements that produced the valley have progressed intermittently during a long period of time.

In most regions the geologic record of mountainmaking movements is even less complete than in Utah Valley. Can we be sure that the more ancient diastrophic changes elsewhere were, on the average, any more vigorous or violent than in this valley? If the geologic record back to the beginning of Paleozoic time were as complete as the Pleistocene record in Utah Valley we might find that the earth has been undergoing virtually continual deformation since the beginning, that mountain-making movements in different parts of the world have so overlapped as to span all the elapsed time, and that the strains in one part of the crust became relieved and movement ceased as new strains and new movements developed elsewhere. Continued and unbroken sedimentation in the interior of a geosyncline remote from the mountains that were being eroded to furnish the sediments is not evidence that there was a lack of repeated movements in those mountains. On the contrary, the very constancy of the supply of sediments, both as to volume and kind that characterize so many of the ancient geosynclines, strongly suggests that their source mountains were not catastrophically raised and then eroded to mere stubs, but that the mountains were being raised all the while they were furnishing sediment to the geosyncline, in the same way that the growing Wasatch Range furnished sediments to Utah Valley during Pleistocene time.

HISTORY OF SEDIMENTATION IN THE VALLEY

In late Tertiary time there accumulated in the valley a considerable thickness of well-stratified volcanic debris (Salt Lake formation), evidently deposited in part in quiet water probably under lake or playa conditions. Some of these water-laid beds are tuffs that represent ash falls for they contain abundant, well-preserved, fragile glass shards. With these are beds that seem to be largely reworked ash, probably material washed into the late Tertiary playa or lake from the pyroclastic deposits that fell on the adjoining highlands. Conglomerates representing erosion of the lavas and other bedrock formations in the adjoining highlands are interstratified with the tuffs and reworked ash.

The extent of the old lake in which these sediments were deposited is not known, but because the block faulting which formed the valley probably was already well advanced it seems likely that the late Tertiary lakes or playas corresponded roughly to the present valley areas. Absence of any traces of lacustrine features (shore-lines) above the Bonneville formation shore-line is indicative that none of the earlier lakes exceeded Lake Bonneville in size, particularly because the mountain blocks have been rising progressively.

About the time that the volcanism waned the late Tertiary lake disappeared or at least greatly diminished in size. The history of sedimentation during pre-Lake Bonneville Pleistocene time still is fragmentary but apparently it includes periods when huge alluvial fans were constructed far into the interior of the valley, separated by at least three periods when lakes, presumably glacial lakes like Lake Bonneville, were created. (See fig. 5.) The fanglomerate that was deposited immediately preceding Lake Bonneville is like that being deposited today and very likely represents mudflows and other flood deposits that accumulated under topographic and elimatic. conditions similar to those of today.

About 17.5 cubic miles of sediment are included in these pre-Lake Bonneville Pleistocene deposits, which is equivalent to an average lowering of roughly 95 feet in the adjacent mountains which were the source of the sediments (p. 37).

The Pleistocene was concluded by the epoch of Lake Bonneville and the latest glaciation, presumably equivalent to the Wisconsin. During the earliest stage of Lake Bonneville vast quantities of fine-grained sediments (Alpine formation) were deposited in the lake. The Alpine formation has a volume of about 2.6 cubic miles (p. 37), and probably more than half of this material is silt size or finer. Its volume and proportion of fines exceed that of any of the later deposits. This large volume of material represents an average of about 14 feet of erosion from the entire surface of the tributary highlands, but the sediment could have been deposited rather quickly if, as seems likely, it represents accelerated erosion of a deep soil rather than direct erosion of the bedrock itself.

This first advance of Lake Bonneville seems to have preceded, somewhat, the glacial maximum represented by the younger of the moraines at the mouth of Alpine Canyon; outwash from that moraine overlies the Alpine formation but gravel deposits interbedded with the finer-grained sediments of the Alpine probably represent glacial outwash that formed during the advance of the glacier.

Gilbert (1890, pp. 141-146, 260) has presented evidence to show that during this first stage of Lake Bonneville the lake surface oscillated and the stage was followed by dessication. In Utah Valley no evidence was found to demonstrate that the lake surface oscillated, while the Alpine formation was being deposited, but there is evidence that the formation was exposed 
and eroded before the Provo formation was deposited. The Provo formation overlaps the eroded edges of the Alpine formation and in places rests on pre-Alpine deposits suggesting that the Alpine had been removed be erosion. Moreover, at many places in the valley there is a striking disconformity between the contorted beds of the Alpine formation and the overlying undisturbed beds of the Provo formation.

Lake Bonneville rose to its maximum height when the Bonneville formation was deposited. In Utah Valley only gravelly littoral deposits have been recognized as belonging to this stage and their volume is insignificant in comparison with that of the Alpine. The stage seems to have been short-lived.

Above the town of Alpine the Bonneville formation is composed very largely of granitic boulders and pebbles derived from the outwash from the younger of the moraines at the mouth of Alpine Canyon.

When the highest stage was attained Lake Bonneville overflowed into the Snake River valley by way of Red Rock Pass (Gilbert, 1890, p. 260) and the lake level fell rapidly to the level of the Provo stage-in Utah Valley about 300 feet lower than the Bonneville level.

At the Provo stage large deltas were built in the lake at the mouths of the principal streams draining the Wasatch Range. . During this stage the lake currents moved northward along the front of the Wasatch Range, for the deltas have a sand facies northwest of a medial gravel facies, and sand and gravel bars off the front of the deltas were built northwestward.

The Provo formation has a volume of about half a cubic mile, of which probably less than a fourth is silt size or finer. The proportion of coarse and fine-textured material transported into the lake during the Provo stage is rather like that being brought in today and is quite unlike that brought in during the earliest stage when the Alpine formation was deposited. The texture of the Provo formation suggests that the extent of soil cover in the mountains at that time was only a little greater than at the present time. The volume of the Provo formation represents only a few feet of lowering of the surface of the adjoining highlands.

After the Provo stage the lake fell gradually to the level of Utah Lake. Detailed study of the succession of bars (or beaches) that lie in front of the deltas no doubt would furnish considerable information regarding the fall of the lake from the Provo level, for the bars appear to have formed during this period. Since then only minor fluctuations of level have been recognized. The Stansbury stage (Gilbert, 1890, p. 134), which roughly conforms to the level of Utah Lake, has not been recognized in Utah Valley.

Since Provo time most of the valley has been subject to fluviatile sedimentation and erosion. The principal streams have cut channels across the old deltas and have built broad low fans on the plain formed by the lake-bottom sediments in front of the deltas. Along the fronts of the mountains the old alluvial fans are again being enlarged as boulders and finer sediment are being washed onto their surfaces. But the total volume of material brought into the valley since Provo time is only one-tenth the volume of the Provo formation.

The differences in texture and form of the several Pleistocene deposits in Utah Valley appear to be related only remotely if at all to the succession of structural movements that occurred while the deposits were forming. Instead, as outlined in the following section of this report, the differences resulted primarily from variations in the climate.

\section{LAKE BONNEVHLLE-A WISCONSIN LAKE}

That the older of the moraines in Alpine Canyon is pre-Wisconsin is indicated by the thick layer of clay on its surface which is the result of residual weathering of the deposit. This ancient soil is assuredly a preWisconsin phenomenon (Hunt and Sokoloff, 1950), like the gumbotil in the Middle West (Kay, 1916, pp. 637-638). It is described more fully on page 43. The younger moraine lacks this soil and evidently is one of the Wisconsin moraines.

Interstratified with the Alpine formation along Dry Creek are beds of granitic gravel that evidently represent glacial outwash. The youngest bed is at the base of the Provo. The meltwaters that produced these deposits probably discharged into the lake at least seasonally even during the time when the glaciers were forming and advancing.

Although the last definite evidence of glacial meltwaters is the gravel bed underlying the Provo formation in the upper part of Dry Creek, very probably the Provo formation itself was supplied by meltwaters during the waning stages of the glaciation. There is no other apparent source for the volume of water and sediment represented by the Provo stage.

Gilbert (1890, pp. 309-310), and later Atwood (1909, pp. 92-93) and Antevs (1925, pp. 74-77) agreed that the maximum of the last glaciation (Wisconsin) in the Wasatch Range occurred before the Provo stage but probably immediately following the Bonneville stage of the lake. The stratigraphic evidence provided by the deposits in northern Utah Valley is consistent with this general interpretation. Still to be explained, however, is the significance of the unconformity between the Alpine and the younger formations of the Lake Bonneville group, which implies that the lake twice reached high level stages in Wisconsin time. 


\section{EVOLUTION OF THE CLMMATE, TOPOGRAPHY AND SOILS}

At the close of Tertiary time the relief of the Utah Valley region must have been nearly as great as it is now. Since the close of Tertiary time the valley floor has been built up by 500 feet of sediments, and at the same time erosion has lowered the mountains an average of about 160 feet. Only if Quaternary faulting exceeded about 660 feet, could relief at the close of Tertiary time have been less than it is now. In all probability Quaternary faulting did exceed this but only by hundreds (rather than thousands) of feet. Nevertheless, during Quaternary time, the landforms and the extent and kind of soil cover must have undergone a succession of major changes because of variations in the climate.

During at least part of late Tertiary time there appear to have been lakes in which the volcanic ash beds were deposited. At that time therefore the precipitation-evaporation ratio was greater than at present.

At the beginning of Pleistocene time conditions changed. Fanglomerates, like those being deposited today, were washed into the valley and very likely the climate, topography, and soils were similar to those of the present time. We may infer that when these earliest fanglomerates were forming, the mountains were practically as high and as rocky and craggy as they are today, the climate probably was semiarid, and the soil forming processes probably were as feeble as they are today.

This semiarid period, however, seems to have ended by a shift to more humid conditions that led to the forming of the first of the Pleistocene lakes. While the climate was more humid the soil-forming processes must have been more vigorous, and the rocks in the mountains may have become cloaked in deep soil that softened the mountain landforms. Very likely too, the first Pleistocene glaciation in the mountains occurred during or immediately following this stage.

Well records in the valley indicate that a cyclic change from semiarid to humid conditions occurred at least three times in the Pleistocene prior to Lake Bonneville, which was the last of the great Pleistocene lakes.

An increase in the precipitation-evaporation ratio is recorded by the rise of Lake Bonneville during the Alpine ("Intermediate") stage. The lake level appears to have fallen by desiccation after the Alpine formation was deposited. This suggested aridity may be more apparent than real, because about this time one of the sets of Wisconsin glaciers formed on the mountains. Their melting and the return of apparently more humid conditions caused the lake to rise to the Bonneville level. This climate probably continued almost to the close of the Provo stage. From then on the precipita- tion-evaporation ratio decreased, evaporation became excessive, and the lake level fell.

The distribution and changes in facies of the Lake Bonneville group show that along the east side of Utah Valley the shore currents of the lake were northerly, certainly so during the Provo stage, and probably also during the Bonneville and Alpine stages. This would indicate that during the existence of Lake Bonneville the prevailing winds came from the southwest. This contrasts with the record of the last 20 years or more during which the prevailing winds have come from the north and northwest.

Some ancient and deep soils on the mountains apparently record stages when the climates were humid. At the time these soils were formed weathering conditions were favorable for developing smoothly rounded slopes on what had been rocky and craggy surfaces. Remnants of the smoothly rounded landforms are still preserved in parts of the Wasatch Range and conspicuously so in the Traverse Mountains. These landforms, the product of past humid climates, are strikingly different from the rugged shapes that are being carved by the processes of the present semiarid climate.

Remnants of the ancient deep soils are still preserved at places on the bedrock, on the pre-Lake Bonneville fanglomerates, and on the older of the Alpine Canyon moraines. At several places the old soils are overlapped by the Lake Bonneville group. It is likely that this deep soil mantling the mountains furnished the fine-grained sediments of the Alpine formation. By Bonneville and Provo time however much of the old soil had been stripped away and the streams again began eroding on bedrock, for those formations are composed largely of coarse detritus.

Since Provo time the climate has become semiarid. Mountains are being carved into rocky landforms characteristic of such a climate, and the modern soils are only feebly developed. Under the present climate practically no soil is being formed on rock surfaces, as erosion today is vastly more effective than weathering

The fall of the lake to the level of Utah Lake permitted Dry Creek, American Fork River, and Provo River to cut deep channels in the unconsolidated deposits of the deltas; the materials eroded from these channels were deposited in broad low fans where the streams issued from the deltas onto the pro-delta silts and clays. The fans at the foot of the mountains have again started to grow and by the same processes that built the older and vastly larger parts of those fans.

The several great Pleistocene lakes that have existed in Utah Valley very likely correlate with the major glacial periods that have been recognized in other parts of the world. Substages in the glacial and inter- 
glacial periods no doubt are also recorded in the sedimentary record and very likely will be revealed rather fully when surveys in the Bonneville and Lahontan Basins have been completed. These basins appear to offer an unusually fine opportunity for reconstructing the climatic record of Pleistocene time.

AN GSTMMATE OF THE GEOLOGIC TIME AND RATE OF EROSION RFPRESENTED BY THE FORMATIONS

Despite grave uncertainties in the available information it is interesting to try to estimate the duration of some of the stages in the Pleistocene history of Utah Valley and the magnitude of the variations in rates of erosion and sedimentation that must have occurred. In a first approach to the problem an average rate of erosion is assumed in order to estimate the time; in a second approach the time is assumed in order to estimate differences in the rates of erosion.

The volume of post-Provo deposits in northern Utah Valley is of the order of one-quarter billion cubic yards, or about 0.05 cubic miles. Post-Wisconsin time has generally been estimated to comprise 20,000 to 25,000 years but recent radiocarbon tests suggest that the duration may be as little as 10,000 years. The radiocarbon evidence is forceful but still to be proved valid, so for present purposes we will assume a compromise figure of 15,000 years.

The Lake Bonneville group, representing the Wisconsin deposits in Utah Valley, aggregates 3.1 cubic miles and at the post-Provo rate of sedimentation this would have required 60 times the length of postProvo time or about 900,000 years. This figure is ten to fifteen times greater than the estimates generally given for Wisconsin time. If the generally given estimates are correct, it would appear that, in Utah Valley, the rate of erosion during Wisconsin time was ten to fifteen times faster than it has been since.

In another approach to the problem it will be assumed first that the duration of the Provo stage exactly equalled the duration of the Alpine stage. These two formations were derived under quite different conditions. The Provo consists of 0.5 cubic miles which is mostly gravel and sand whereas the Alpine consists of 2.6 cubic miles which is mostly silt and clay. If the two stages were equal in duration the rate of erosion during Alpine time was five times as fast as during Provo time. If the Provo formation accumulated at the same rate as did the post-Provo deposits, which also are coarse clastics, the Provo required 150,000 years. The Alpine and Provo together thus would require 300,000 years. Even this estimate is three to five times greater than the estimates usually given for Wisconsin time.
Crude as these estimates are, they do indicate either that Wisconsin time was of greater duration than has commonly been supposed, or that erosion and sedimentation were at much faster rates than during the postProvo epoch. Both may be true.

Also it might be noted that the volume of the Wisconsin deposits, the Lake Bonneville group, is about 18 percent of the total volume of the Pleistocene deposits in the valley. Wisconsin time may constitute about 18 percent of those stages of the Pleistocene that are represented by vigorous erosion in the mountains. But intervening between those stages of erosion were stages when weathering exceeded erosion, stages when deep residual soils developed in the mountains and, seemingly, very little sediment was removed to the valley.

It seems likely therefore that Wisconsin time represents something less, probably considerably less, than 18 percent of all of Pleistocene time.

\section{RELATION OF THE GEOLOGY TO SOME SOIL PROBLEMS}

\section{ANCHENT SOILS}

Some ancient and deep soils that were formed in pre-Lake Bonneville time have been found in Utah Valley. These soils were formed originally by the processes that operated under climates that antedated the lakes and glaciers.

The ancient soils are restricted to the pre-Lake Bonneville deposits, and are further restricted to those areas on those deposits where the surface has been preserved through the Lake Bonneville and post-Lake Bonneville time. These conditions are found at numerous places above the high-water mark of Lake Bonneville along the foot of the Wasatch, Traverse, and Lake Mountains. Old soils are extensive on the preLake Bonneville fanglomerate, on the older of the moraines above the town of Alpine, and on the Paleozoic and other bedrock formations. In the development of the ancient soils, a product was created wholly different from the original parent material.

The ancient soils consist of an upper layer that is lime-free and clayey and a lower layer that is composed of lime-enriched, weathered parent material.

The upper layer, which locally is as deep as 10 feet, is deep reddish brown, granular, and very sticky loam or clay. Downward it becomes lighter-colored and more yellowish brown. It contains few pebbles and locally is entirely free of pebbles. Most of the pebbles that remain in this layer are quartzite; at places, however, other materials can be recognized but these generally occur as deeply decayed, soft relic pebbles or cobbles. 
Both lime and clay have been concentrated in the lower layer of the ancient soils. This clay commonly is in the upper part of the principal lime-enriched zone. It is very light colored. Some of it is lime-free but most of it is limey; part of this lime is finely mixed through the clay and part is in a fretwork of tiny veinlets. At some places the clay occurs as a distinct layer, at other places it forms lenticular masses, and locally it is $2 \frac{1}{2}$ feet thick. The concentration of lime, however, extends down many more feet. This lime impregnates the weathered parent material, coats pebbles, and forms a network of veins and veinlets that branch downward, evidently the product of downwardpercolating waters. This lime-enriched layer in places is 20 feet thick.

These soils were formed from a variety of parent materials: granitic moraine; fanglomerate composed of quartzite, limestone, and latitic lavas; Paleozoic shale; and Paleozoic limestone. The soils that formed from granitic or quartzitic parent materials have con- the topography. Since the soils were formed the valleys have become deeper and the hillsides steepened. The streams have cut through the upper clayey layer and into the lime-rich layer, and in places have cut into the weathered parent material. At other places hillside wash has buried the ancient soil under more recent material.

Where pre-Lake Bonneville fanglomerate has been elevated and dissected, as for example northwest of Alpine, gullies have cut through the upper clayey layer and into the lower lime-enriched layers. On some of the fans in front of the mountains the old soils are concordant with the present surfaces of the fans, but locally the soils are buried beneath younger gravel. It would be expected, therefore, that the clay layer of the ancient soils would be thinned irregularly by erosion and would be modified by the addition of lime derived from the younger wash on the surface of the ancient soil. These general relations are illustrated diagrammatically in figure 10 .

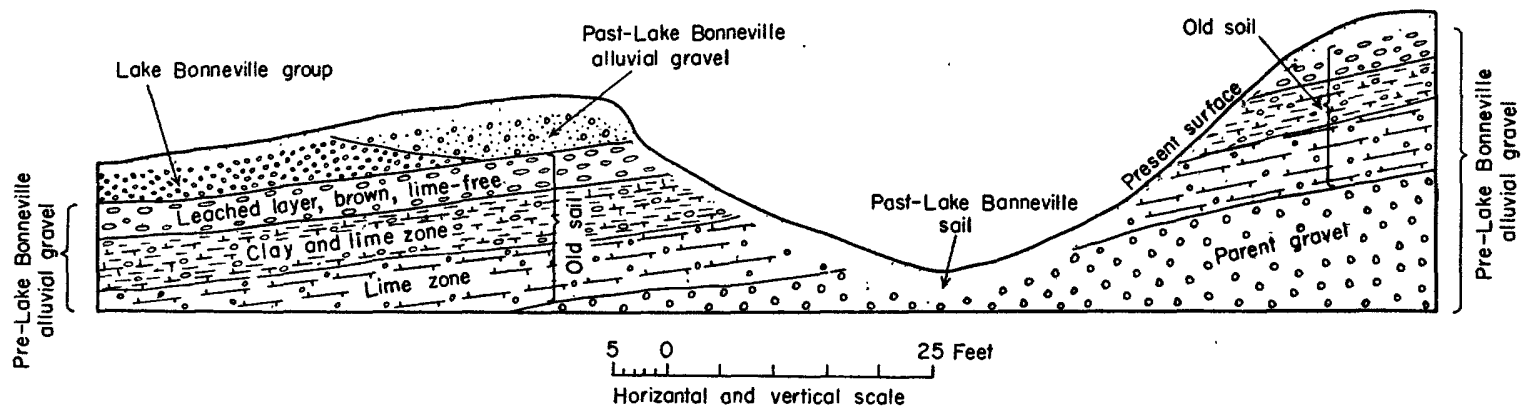

Figune 10.-Diagrammatic section to illustrate some relationships between the geology and soil development in northern Utah Valley. An ancient and deep soil in the preLake Bonneville alluvial gravel is discordant to the present topography and is overlain by Lake Bonneville group and post-Lake Bonneville alluvial gravel. A post-Lake Bonneville soil is feebly developed on the Lake Bonneville group and younger deposits and probably is superimposed on the ancient soil too.

siderable sand in the upper clayey layer. Approximately 65 percent of this clay can be washed through a 325-mesh sieve. Only small amounts of calcium carbonate occur in the lime-enriched layer of soils on nonlimey parent materials. The soils that formed from Paleozoic limestone or shale, or fanglomerate derived from them, have a highly clayey upper layer above a thick and strongly lime-enriched layer containing weathered fragments of the parent material. More than 90 percent of the clay layer in soils that formed from shale formations can be washed through a 325 -mesh sieve.

The considerable depth of these ancient soils is the more impressive because of the fact that many of the localities are on moderately steep hillsides where runoff and surface wash would be favored.

These soils are overlapped by the Lake Bonneville group. Their occurrence today is restricted to those pre-Lake Bonneville surfaces that have been preserved. Today the ancient surfaces are being dissected, and the profiles of the ancient soils now are discordant with
Soils like these are not found on the Lake Bonneville group and younger deposits. On the Lake Bonneville group and younger deposits the soil profiles generally are only 1 or 2 feet deep, except very locally where there has been a concentration of surface water. The depth of a soil profile is largely controlled by the depth to which surface water percolates; in the ancient soils water must have pentrated to depths as great as 30 feet. The depth of the ancient soils commonly is 10 to 15 times the depth of the whole profile of the modern soils. It is evident that the ancient soils must be the product of a past climate or climates wholly unlike the semiarid present.

Still unanswered is the question of the degree to which the ancient soils represent a complex of profiles superimposed on one another. Ancient soils like these provide fine evidence of past climatic changes, as pointed out by Bryan and Albritton (1943, pp. 469-490), and may prove to be a valuable tool for correlating Pleistocene events in provinces where the sedimentary record is lacking. 


\section{MODFRN SOILS}

The soil profiles in the Lake Bonneville group and younger deposits are feebly developed and the texture and composition of the parent material still dominates those soil profiles. This is rather clearly shown by the close similarity between the geological map of Utah Valley and the reconnaissance soil map made in 1903 by Sanchez (1904). Moreover, the modern soils are shallow; they rarely are more than a very few feet deep.

Although most of the soils on the Lake Bonneville group and younger deposits involve only minor alteration of the parent material, there nevertheless must be significant soil differences between some localities that involve similar parent materials. For example, the sand and gravel bars in front of the Highland bench delta have the same composition as the sand and gravel on the deltas, and the internal structure of the two is alike. But on the deltas the sand and gravel is underlain by many feet of like material-all of it permeable; whereas at the bars the sand and gravel is underlain by comparatively impermeable silt at a depth of only a few feet. On this silt is perched considerable ground water. The soil process obviously changes at the perched water table and in addition the soil climate in the sand and gravel above this water table must be very different from the soil climate of the sand and gravel in the deltas.

Other differences in the substrata of other deposits undoubtedly also affect the soil climate and also the plant and (or) animal life of their soils. The silt member of the Provo formation, for example, generally overlies silt or clay of the Alpine formation, but at a few places, notably at Pleasant Grove and locally along the west side of the valley, silt belonging to the Provo formation overlaps highly permeable pre-Lake Bonneville fanglomerate.

Variations in surface drainage conditions in different areas on a single parent material likewise introduce variations in the kind of soil developed on that material. West of the Geneva Steel plant, for example, the clay member of the Provo formation has evidently been subjected to repeated flooding from the marshy ground that formerly existed at the site of the steel plant's reservoir. This clay has at the top a distinct leached zone overlying a distinct lime-enriched zone; the profile extends to a depth of a few feet. Along the bluffs of the Jordan River, however, the same clay has only the feeblest sort of soil profile and this to a depth measurable only in inches.

\section{SALINE SOHS}

Soil processes change the content, kind, and distribution of soluble salts in or on the ground. On the other hand geologic processes control the content, kind, and distribution of soluble salts in the undisturbed parent material.

Some of the orderly variations in the salt content of the Provo and Alpine formations which appear to have been controlled by the conditions of sedimentation when those lake beds were deposited have been pointed out elsewhere in this report (pp. 31-35). The distribution of salts in those lake beds is orderly and the distribution pattern is a factor that must be considered in appraising either the degree or the means by which the soil processes have changed or redistributed the salts. In brief, the "alkali" problem cannot be understood and overcome until there has been ascertained the source of the salts that are found in or on a given piece of ground. At some localities lands may have been damaged because of salts introduced by irrigation waters; at other localities equal damage may result from only slight movement and/ (or) slight reconstitution of the salts left in the ground by earlier geologic processes. Solving the problem requires distinguishing these two very different conditions.

PLEISTOCENE HISTORY AS A FACTOR IN SOIL GENESIS

Pleistocene geological history is a vitally important factor in soil genesis and in some aspects of the problems of soil classification. Probably on every part of the earth and certainly in the temperate zones the present climate is quite unlike the climates of the past, so in order to understand the origin and to properly classify a soil at a particular place it is essential to know to what extent the soil is the product of climatic conditions that no longer prevail. In the same way, the plant and animal life that have lived on and in the soil have changed and at some places even the topographic position has changed. Only the parent material remains constant during the development of a particular soil, and in a strict sense even this can be thought of as varying to the degree that the other changes may cause a new soil profile to be superimposed upon some part or all of an older one. In considering the origin and some aspects of the classification of soils, the geological history of the soil is unimportant only where the soil is so recent that it is entirely the product of present-day processes.

Soils like the ancient soils in Utah Valley are not found on the Lake Bonneville group or younger deposits. Since Lake Bonneville time the climate has been arid or semiarid and the soil-forming processes have been feeble. Soil profiles on the Lake Bonneville group and younger deposits rarely are more than 2 or 3 feet deep except where there has been a concentration of surface water simulating more humid conditions. It cannot be assumed that the differences between the pre-Lake Bonneville and the younger soils are due primarily to 
the difference in the length of time available for the two kinds of soils to form, because the ancient soils formed under conditions wholly unlike the present. It is even possible that the ancient soils formed in less time than did the modern ones.

The depth of a soil profile is very largely controlled by the depth to which water penetrates, and under the present climate water penetration is very shallow except at especially favored localities. The ancient soils are 10 to 15 times as deep as the modern soils. Regardless of the time factor, therefore, the modern climate could not develop soils as deep as the ancient ones.

Time probably has been overemphasized as a factor in soil genesis. Time of course is important but chiefly because the passing of considerable time witnesses major changes in the other factors-especially the climate and organisms - that are more fundamental to the process. Many thousands of years, for example, have elapsed since Provo time, yet the climate and organisms have been such that only very feeble soil profiles have formed during those thousands of years; the profiles still are dominated by the kind of parent material on which they formed. On the other hand, it is quite possible that much briefer periods of time during the past, when the climate was different, would suffice to impose strong soil profiles whose upper layers in no way resemble the parent material.

Time alone would appear to affect the degree, rather than the kind, of alteration that results in soil. Given sufficient time, however, a soil will reach equilibrium with the environment in which it is forming; it will become mature. But the length of time required for soils to attain equilibrium varies with the kind of environment. In this sense, the feebly developed modern soil profiles may be fully as mature as the strongly developed ancient ones.

Similarly, the topographic position of a localitythat is, its slope and exposure-on which soil forms, in general affects the degree rather than the kind of alteration that results in soil. The ancient soils in Utah Valley are very much alike regardless of their topographic setting, and the modern soils that developed on one kind of parent material are much alike regardless of their topographic setting. More important to soil development than either time or topographic position are the factors of climate, parent material, and organisms.

Probably equally important to the factors of time and topography is a factor that has not been emphasized sufficiently-geologic environment, especially the stratigraphy and geologic structure in and around a particular soil. The importance of this factor to soil development in Utah Valley is illustrated by the several varieties of the modern soils that are due to differences in the kind of deposit that lies below the parent material. The kind of subsoil significantly affects the moisture and other soil-climate conditions in the overlying soil. Drainage generally is recognized as highly important in soil development, but drainage is conditioned mostly by geologic environment, namely the permeability of the underlying materials, which is determined by the stratigraphy, and the depth to the saturated zone, which is commonly a function of the regional geomorphology and geologic structure.

Five factors generally are cited as controlling soil development. These are climate, parent material, topography, organisms, and time. To these should be added the sixth factor, geologic environment; and distinction should be made between those factors that primarily control differences in kind of weathering and those that primarily control differences in degree of weathering. Furthermore it should be emplasized that each of the factors is in itself a variable depending on geologic history. The six factors might be organized and phrased as follows:

Factors that primarily control difference in kind of weathering:

1. The kind of climate or succession of climates under which a soil material formed.

2. The kind or kinds of parent material from which a soil was derived.

3. The plant and animal life, past and present, that have lived on and in a soil.

Factors that primarily control differences in degree of weathering:

4. The topographic position, past and present, of the locality.

5. The geologic environment, past and present, of the locality.

6. The length of time that each condition in each of the other five factors has been operative.

SOME GEOLOGICAL ASPECTS OF EROSION AND FLOOD CONTROL PROBLEMS

The streams that normally bring much needed water to Utah Valley occasionally reach flood stages and bring destruction. When they are in flood, they erode land under cultivation or along roadbeds or elsewhere, by flowing outside of the normal channels. In addition, they deposit debris where it is unwanted. Considerable work has been undertaken in order to give protection against such damage. Much of this effort is obviously of only temporary value, perhaps made during a flood, for the protection of a specific structure or tract of land. More and more people have realized that such stopgap measures are inadequate, and that watersheds must be managed on the basis of comprehensive and long-range planning, if the water crop produced by them is to give maximum benefit and minimum damage. 
The effectiveness of land management depends upon the understanding and proper evaluation of the natural processes and forces involved. The geologic factors are important among those that need to be understood and evaluated.

For appraising the geological aspects of erosion and floods in Utah Valley the geologic history can be divided into three main periods represented by the pre-Lake Bonneville deposits and soils, Lake Bonneville deposits, and post-Provo deposits and soils.

The only strongly developed and deep soils in Utah Valley are those ancient clayey ones that were formed prior to the period of Lake Bonneville. Soils that are post-Provo in age are only feebly developed and are shallow as compared to older soils. The ancient soils are erosion remnants or have become buried by younger deposits; in either case they face extinction. In the strictest sense of the word they are an irreplaceable resource. We cannot hope to stop completely the removal or burial of these ancient soils but we can hope to avoid wasting them.

The largest part of the ancient soils apparently was eroded from the uplands during the early stages of Lake Bonneville when the Alpine formation was deposited. Most of the 2.6 cubic miles of that formation apparently represents erosion of the deep clayey soil that had formed extensively in the mountains, and the volume represents an average 15-foot lowering of the whole surface of the adjoining highlands (p. 37), an amount that is entirely consistent with the known depths of the ancient soils. The quantity of ancient soil remaining around Utah Valley is only a trifling fraction of the original; the quantity eroded since man reached the area is negligible as compared to the quantity that was eroded before he arrived.

Under the present climate the forces of erosion are vastly more powerful than are the forces of weathering. A climate that impresses such feeble soil profiles on the unconsolidated deposits in the valley could hardly be expected to develop soil on firm rock; this is reflected in the high proportion of boulders, pebbles, and smaller rock fragments now being transported into the valley by streams eroding the highlands. It is very unlikely that the unconsolidated deposits and soils that remain in the highlands are being replenished. They face removal as surely as do the ancient soils preserved around the edges of the valley. Under the present climate the mountains seem to be destined to become more rugged and rocky.

During parts of pre-Lake Bonneville time also the forces of erosion evidently exceeded the forces of weathering and soil formation. The debris eroded from the highlands during those periods and accumulated as fanglomerate, in all respects resembles that being brought into the valley today. During that time the Wasatch and other ranges must indeed have been bare and craggy. Many cubic miles of rock debris were eroded from the highlands during the semiarid periods that preceded Lake Bonneville (p. 37).

The post-Provo deposits aggregate about 0.05 cubic mile, or about $250,000,000$ cubic yards. If post-Provo time totals 15,000 years the average annual quantity of debris washed into the valley would be about 15,000 cubic yards. At this average rate $1,500,000$ cubic yards would have been washed into the valley during the 100 years of occupancy by white man. Precise measurements are lacking and the figures cited have little quantitative value, but it is exceedingly doubtful if the rate of influx of rock and debris since man's arrival significantly differs from the average that prevailed during the several thousand years preceding 1850.

As long as the present climate continues there will be continued erosion in the mountains, continued floods into the valley, and continued feebleness of soil development-for these are the results of such a climatic pattern upon this area. Thus the soils on the uplands bordering Utah Valley are an irreplaceable resource. Protection of vegetative cover, check dams, and other expedients are designed to minimize the destructive effects of these natural forces. But they do not modify the climatic, geologic, or physiographic factors that are the major causes of floods and erosion. Many efforts to date have been expedients that do not guarantee security against disaster, and they should not be judged harshly when they fail. Much more research on the powerful natural forces involved is needed, in order to find means of supplementing and working with those forces, rather than against them.

\section{ENGINEERING GEOLOGY}

By Helen D. Varnes

The geology of Utah Valley is directly related to the wide variety of uses to which the natural materials are or can be put. Each geologic unit, by reasons of its composition and the method by which it was formed, has distinctive sets of properties that determine the extent and limitations of its possible uses.

The geological study of the valley enables one to obtain an over-all picture of the engineering properties of the various materials - a picture useful in the early stages of planning for large-scale construction such as new road alinements, canals, or industrial buildings. Adequate data on the kind and distribution of the earth materials that make up Utah Valley facilitate location of construction materials such as gravel, sand, and riprap, and can also be used in making preliminary estimates on excavation and fill requirements. Sub- 
sidence of foundations and roads, excessive leakage in irrigation ditches, and similar problems are directly tied to the geologic environment; hence knowledge of the geology affords an explanation of the source of these troubles in already-existing structures and makes it possible to foresee and prevent them in new construction.

The manner in which materials are used largely determines which of their properties are significant. For this reason, this discussion of the engineering properties of the formations in Utah Valley is divided into three sections: foundation materials; construction materials unprocessed except by screening or washing; and construction materials that are processed in some manner, such as the burning of clay for brick or tile, or the dressing of building stone.

On the Engineering Geology map (pl. 2) the deposits are separated into map units based primarily on the posed and a symbol given to indicate the relative position of each. For example, a deposit of river gravel overlain by 10 feet or less of silt has the silt-clay and the gravel patterns superimposed with the symbol $\frac{\mathrm{Si}-\mathrm{Cl}}{\mathrm{Gr} 2}$ to indicate that the silt-clay deposit overlies the river gravel.

Where the same material persists to depths greater than 10 feet, or where possible superposition of materials at less than 10 feet could not be detected, only the pattern and symbol for the surficial material are shown. It is probable that many more areas than are shown on the present map should be patterned to represent changes in materials at shallow depths. A complete and accurate determination of such relationships throughout the valley would require an extensive program of trenching and deep auger holes that was

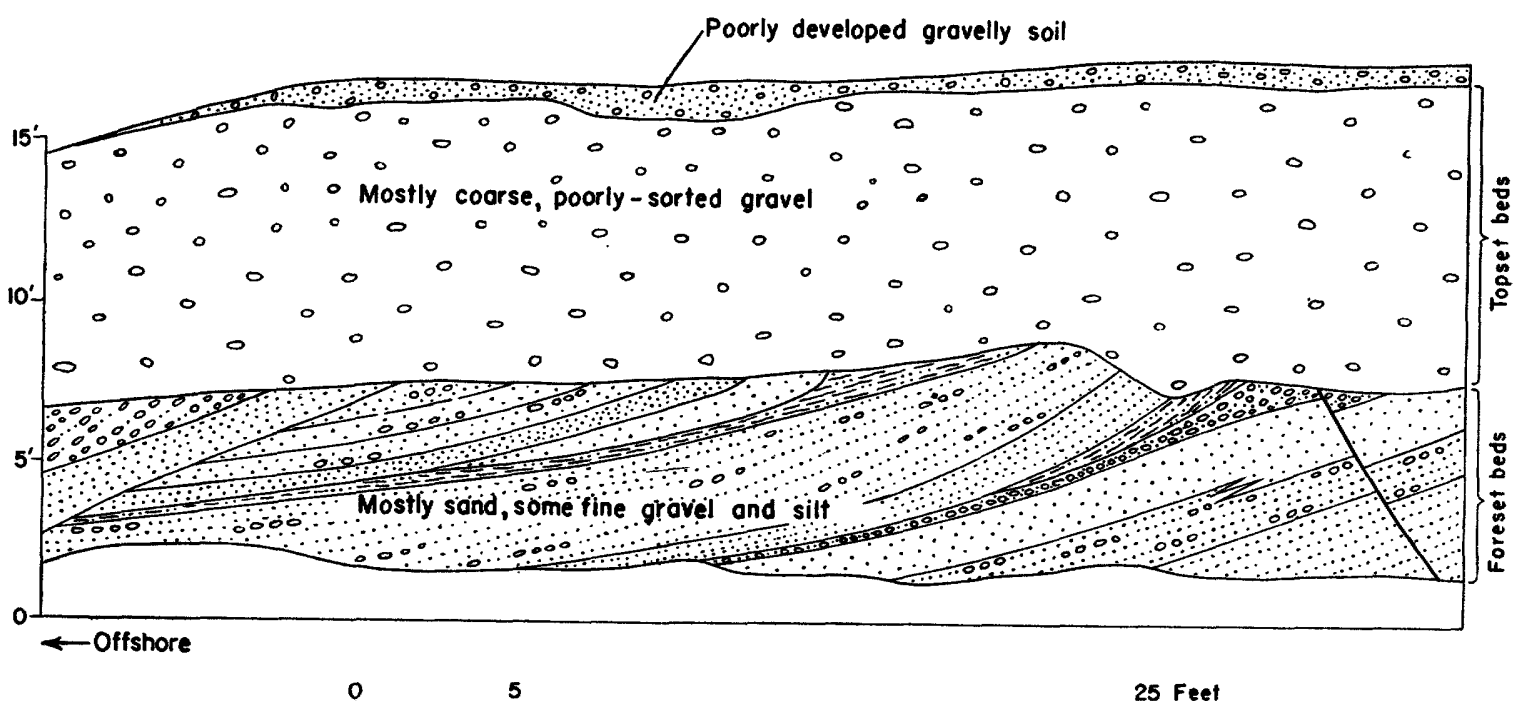

Figure 11.-Cross section showing characteristic bedding in a delta tront. Horizontal, poorly sorted topset beds overlie sloping, well-sorted foreset beds. Exposure is of gravel member of the Provo formation in the Johnson gravel pit (center of the N1/2NW1/4 sec. 18, T. 5 S., R. 2 E.).

kind of material predominating in each deposit, such as gravel, sand, mixed sand and gravel, and so on. The kinds of material and their attendant properties are governed largely by mode of deposition and parent materials; for engineering purposes the chronology of the deposits is not important.

The depth to which a specific material extends is as important as its areal extent in the consideration of foundation conditions or in estimating available reserves of construction materials. An attempt has been made, therefore, wherever sufficient information was available, to indicate vertical as well as lateral differences in composition.

Wherever the thickness of one material overlying another material was known to be 10 feet or less, the patterns representing the two materials are superim- not possible within the scope of the present study. Ten feet was chosen as the critical point principally because information to determine superposition of materials at a greater depth could not be obtained for large enough areas.

Still another aspect of the geology that concerns engineering problems is the seismic activity along the front of the Wasatch Range. A brief summary of the known seismic history is included in this chapter.

\section{FOUNDATION MATERIALS}

Foundation materials in Utah Valley serve to support such structures as buildings, roads, bridges, canals, and small check dams. Their usefulness can best be judged by examining the properties that affect foundation and excavation conditions. The more important properties 
are drainage and permeability, stability and shearing strength, and workability. As these properties of the various geologic units can be consistently compared on the basis of general field examinations and available service records, they seem to offer the best basis for discussion of the Utah Valley materials.

\section{BENCH GRAVEL}

The principal deposits of bench gravel (gravelsized material is greater than 2 millimeters in diameter) comprise the deltas (fig. 11) built into Lake Bonneville by Dry Creek, American Fork and Provo Rivers, and also comprise the great spits at the Point-of-theMountain. In addition there are some small lake terrace deposits. Most of these bench gravels are composed of moderately well graded to poorly graded, surface. In this area excavations deeper than about 10 feet may encounter appreciable quantities of water.

Stability.-The lime-cemented zones in the bench gravels have moderate to high strength depending on their content of cement. Uncemented deposits have low internal friction when dry and without support are unstable in high-angle cuts. In general the gravels are good foundation material with little tendency to settle.

Workability. - The gravel can be excavated easily although the strongly cemented zones locally may require blasting.

\section{RIVER GRAVEL}

The river gravel deposits are largely confined to the channels and flood plains of Provo River, American Fork River, and Dry Creek, the principal streams

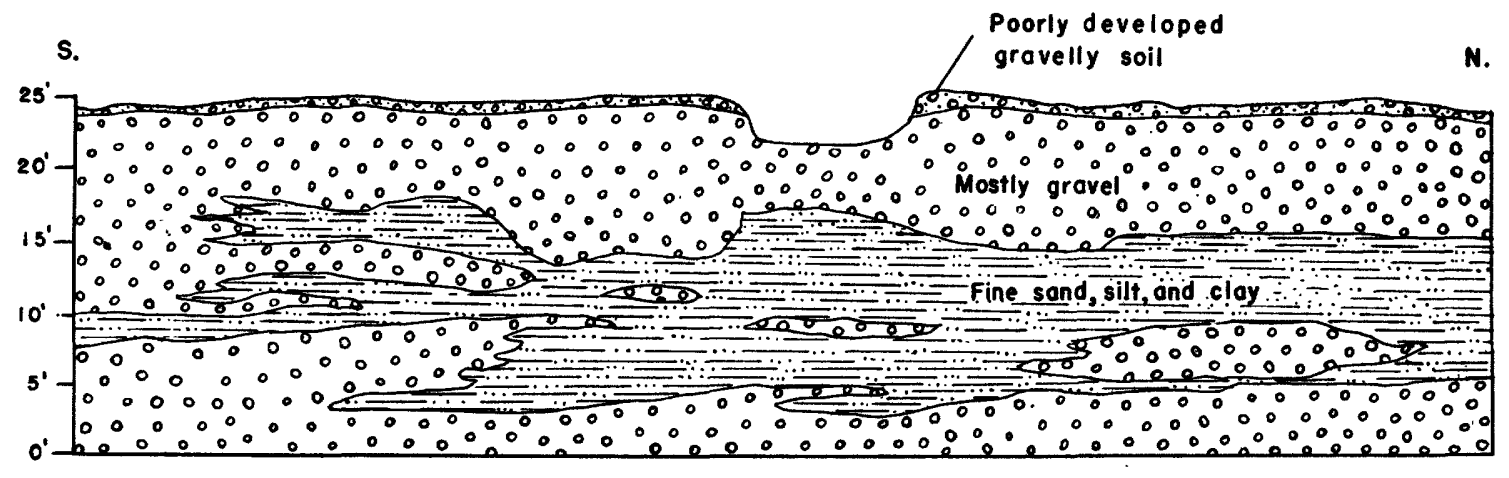

0

100 Feet

FIaure 12.-Cross section of post-Provo river-laid gravel deposits at A merican Fork. Gravelpit in the SW1/48E1/4 sec. 13, T. 5 S., R. 1 E.

rounded pebbles with a low percentage of fines, usually much less than 30 percent. On the map (pl. 2) they are shown as bench gravels $\left(\mathrm{Gr}_{1}\right)$.

Permeability and drainage.-The bench gravels are highly permeable. Water losses in them would be considerable, and water-control structures require lining. Most of the delta gravels, however, are more or less impregnated by lime cement (calcium carbonate) which partly coats the pebbles and reduces the porosity of the mass. Generally the cement is most strongly developed near the tops of the deposits, but locally it impregnates a zone as deep as 12 feet; permeability in such places is low. The lime-cemented zone, however, is seldom so tight that it interferes completely with ground drainage. Because the bench gravels lie considerably above the permanent ground-water table, excavations will generally be well-drained to depths of a few tens of feet. The area between Dry Creek and Mitchells Hollow may be an exception, for a perched water table lies on an impervious bed of clay of the Alpine formation, which apparently has a very irregular draining into northern Utah Valley. On the map (pl. 2) they are shown as River gravels, gr $_{2}$. Riverlaid gravels characteristically vary widely in grading and texture because the capacity of rivers to carry and deposit material varies seasonally as well as at different stages of a single flood. A rude lateral variation in the deposits is generally found, however. Where the rivers leave the mountains, grading is very poor and the material includes boulders a foot or more in diameter. Fines of sand size or smaller are often negligible in amount and localized in occurrence. The average size of the gravel decreases downstream, the percentage of fines increases, and the deposits are generally well graded.

The gravel pit in the American Fork River flood plain (SW/4SE $1 / 4$ sec. 13, T. 5 S., R. 1 E.) is typical of the river gravels deposited a few miles from the mountain front. Most of the coarse material ranges from $1 / 4$ to 2 inches in diameter. These gravel beds, however, are lenticular and in most places interstratified with irregular beds of fine sand, silt, and clay (fig. 12). 
Permeability and drainage.-Permeability of the river gravels, like the bench gravels, is generally high. The river gravels are largely free of lime cement, although there is a notable exception in the vicinity of Alpine where the flood-plain deposits along Dry Creek apparently include deposits that are older than most of the other exposed river gravels. The percentages of fines mixed with the river gravels is considerably greater than in the bench gravel deposits but probably does not greatly reduce the porosity. Silt and clay lenses are interbedded with the gravel and impede drainage locally; they can be expected to occur with increasing frequency and thickness toward the mouths of the rivers. Water-control structures in the river gravels generally require lining to prevent excessive loss.

River gravels that occur along the valley bottoms have high ground-water and at such places, drainage difficulties may be encountered in excavations more than a few feet deep.

Stability.-The river gravels have relatively low strength when dry although the greater admixture of fines locally gives a higher internal friction than is commonly found in the uncemented portions of the bench deposits. Most high-angle cuts crumble and slump if they are left unsupported.

Workability.-Except in the vicinity of Alpine, the river gravel beds are not consolidated and can be easily excavated.

\section{MIXED GRAVEL AND SAND}

Most of the deposits of mixed gravel and sand (shown on plate 2 by the symbol gr-ss) lie along the outer margins of the deltas. Most of these deposits are composed of sloping beds of sand and small gravel capped by horizontal layers of coarser gravel (as much as 2 inches in diameter).

Permeability and drainage.-The gravel-sand deposits are very permeable. Some lime cement is present in the coarse horizontal gravel layers, but the quantity is not enough to impede drainage. Except near their contacts with silt and clay deposits, these deposits lie above the permanent ground-water table. Even near the silt-clay boundaries, excavations less than 10 feet deep will be well drained.

Stability.-The uncemented gravel and sand deposits have low internal friction when dry. They are unstable in high-angle cuts.

\section{SAND}

The sand deposits occur in the deltas and in bars in front of them. On the map (pl. 2) they are shown by the symbol ss. The sand is usually moderately rounded and poorly to fairly graded. Appreciable quantities of silt and clay are found in the areas on the Highland bench east of Dry Creek and at the north end of most of the bars. Elsewhere the percentage of fines is relatively low.

Permeability and drainage.-Permeability is moderate to high and drainage is good except in the delta sands east of Dry Creek where the sand is very silty. The sandbars in front of the deltas generally are less than 10 to 15 feet thick and commonly only a few feet thick. Beneath the sand are beds of silt or clay; there is seepage along the top of these impermeable layers.

Stability.-The sand has very little dry strength and is not stable in high-angle cuts. The sand areas themselves will support loads with little settling, but heavy foundations in all the sand-bar areas would probably need deep piling or other types of support because of the underlying silt and clay. Some of the buildings of the Geneva steel plant are located on a broad shallow bar (sec. 8, T. 5 S., R. 2 E.) and required deep piling in order to insure safe foundations.

\section{SILT AND CLAY}

The deposits of silt and clay are lake deposits, shown on the map (pl. 2) by the symbol si-cl. Mechanical analyses (fig. 13) indicate that the material is a lean clay with some variations to clay loam and to medium or heavy clay and includes little material that could be classified as true silt. Close to sandy areas the material may be transitional to sandy clay. These silt and clay deposits are more widely distributed over Utah Valley than any other material. They are most extensive in the low areas bordering Utah Lake.

Permeability and drainage.-The silt and clay have rather low permeability; drainage is fair to very poor. Canals or other water-control structures excavated in these materials generally show little water loss even where the ground-water table is considerably below the canal bottom. Although the texture of the silt and clay produces poor drainage, their topographic location and expression are of prime importance in determining the drainage difficulties which may be encountered in construction.

The silt-clay bodies which lie at or above the level of the Highland and Orem benches are topographically favorable for good drainage. They have pronounced slopes which are mostly greater than 5 percent and less than 15 percent, although some slopes are as steep as 30 percent. Surface runoff is good and the ground does not become saturated with water below the upper 2 or 3 inches except after unusually long steady rains or melting of snow. These areas are generally underlain by permeable alluvial fan material in which the permanent water table is more than 100 feet deep.

On the other hand, the silt and clay in front of the benches underlie land which is not much higher than Utah Lake, and ground-water level is commonly within 

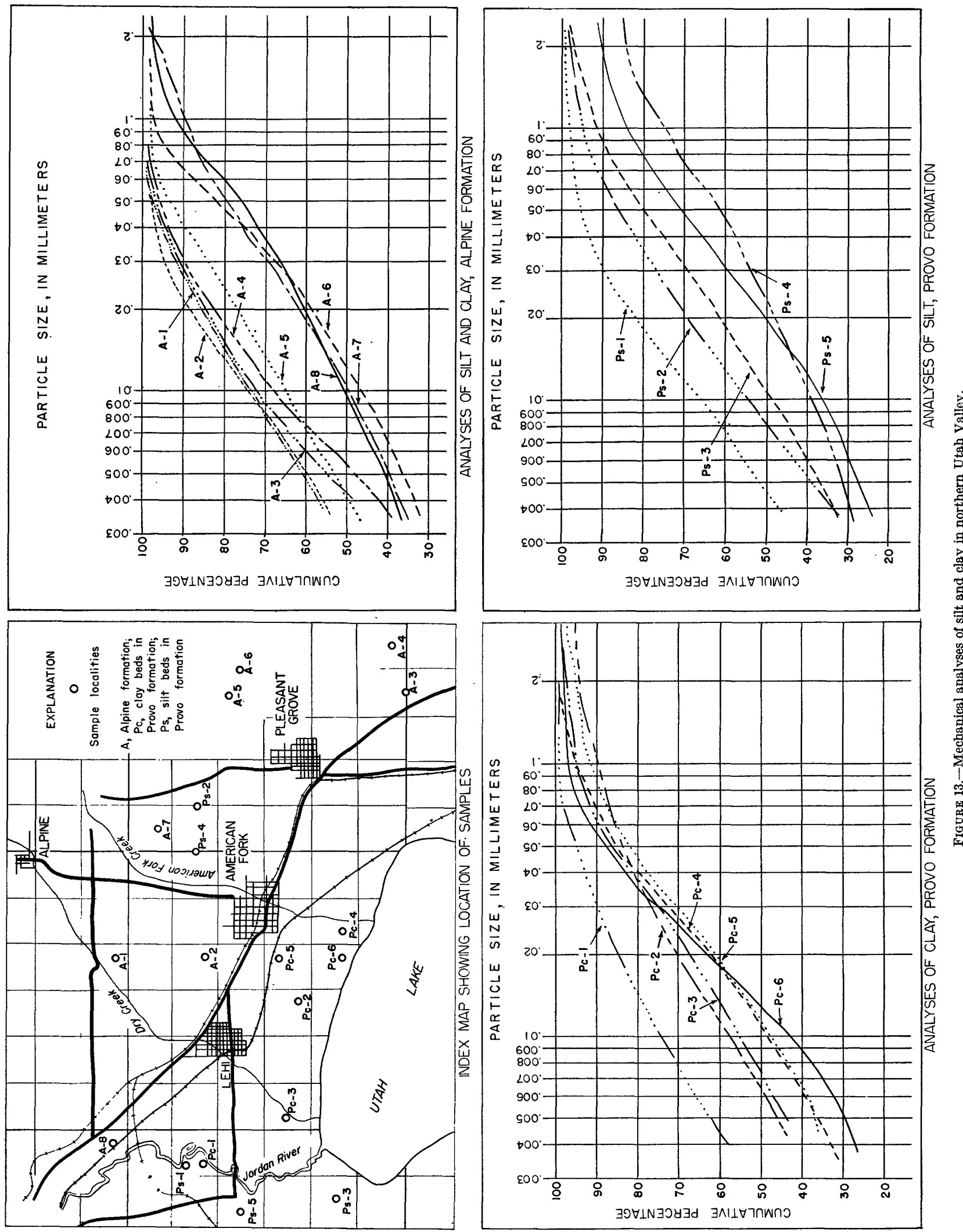
a few feet of the surface. Moreover these areas are so nearly flat that runoff is very slow. Heavy or prolonged rains saturate the ground and commonly leave standing water wherever there is a slight depression. Marshy, even boggy, ground is found in many places.

Stability.-The silt and clay deposits have a moderate to high dry strength, depending on amount and grading of the clay present. Shearing strength of the wet material is uniformly low. In general this material is poor for foundations. Heavy loads will settle appreciably unless supported by piling. Excavations generally hold vertical walls as long as the material remains dry. Moderate slopes usually maintain themselves when wet, although they gully readily under heavy rains.

Near the cities of Provo, American Fork, and Lehi, the foundation conditions are somewhat better than in most of the other silt and clay areas, because the silt and clay beds are commonly underlain by gravel deposited in former flood stages by the Provo River, American Fork River, and Dry Creek. Wherever the silt and clay cover is known to be less than 10 feet deep, this condition has been indicated on the engineering geology map (pl. 2) by a striped pattern combining the symbols for the overlying silt and the underlying gravel. By the nature of their origin as flood deposits, the extent and thickness of the gravel beds are highly variable. Because of this variability of materials beneath a 3- to 20-foot cover of silt and clay, foundation conditions must be determined by drilling and testing.

Workability.-The dry silt and clay can be readily excavated. Even the hard heavy clays can be easily handled with power tools although the handling, of course, is more difficult where the ground-water table is high.

\section{UNSORTED MATERIALS (ALLUVIAL-FAN DEPOSITS)}

The alluvial-fan deposits that are shown on the map (pl. 2) as gr-cl include alluvial fans of pre-Lake Bonneville age as well as some of the post-Provo alluvial deposits built by small streams at the mountain fronts. The alluvial-fan deposits are almost entirely unsorted mixtures of angular and subrounded rock fragments with varying percentages of silt, sand, and clay. The percentages of coarse and fine material differ greatly with each deposit. Some have less than 20 percent silt and clay; in others as much as 90 percent of the material is fine sand size or smaller.

Permeability and drainage.-In the fan material fronting most of the Traverse Mountains and along the Wasatch Range north of Linden, the percentage of silt, clay, and fine sand commonly exceeds 50 percent. The permeability in these deposits is low and drainage is only fair to poor. Water-control structures com- monly show reasonably low losses, less than 14 percent, but the deposits are irregular and very permeable material is present locally. In these areas excavations for foundations probably would drain slowly. However, the drainage conditions generally are satisfactory because the topography favors runoff and the groundwater table is generally low.

The two areas in which the fan deposits show the most extreme local variations in the percentage of fines are the benches south of the latitude of Linden and in the $\mathrm{SE}_{3} / 4$ sec. $24, \mathrm{~T} .4 \mathrm{~S} ., \mathrm{R} .1 \mathrm{~W}$. immediately east of Point of the Mountain. At many places within these areas the fine fraction makes up less than 30 percent of the total volume. Correspondingly, there is a wide range in permeability; limited areas in which canals and reservoirs may require lining to prevent excess water loss are fairly common.

Stability.-The wet strength of the fan materials is generally fair to good. Dry strength is fairly high in areas north of the latitude of Linden; in deposits along the mountain front southeast of Linden, where the percentage of fines is lower, the dry strength is probably moderate to fairly low.

The material is fairly stable in high-angle cuts and will stand with little or no support. Stability under heavy load is generally fair, although where the percentage of fines is high there might be appreciable settlement.

Workability.-Most fan material is easily worked except in local areas along stream courses where large boulders may be encountered.

\section{CONSOLWATHD ROCKS \\ TRRTIARY FORMATIONS}

The Tertiary beds are mostly volcanic tuff, sand, and clay and are exposed only in the Jordan Narrows. For the purpose of this report these beds are grouped together although they show a wide range in properties. In general, the Tertiary formations are not hard rocks which require heavy blasting for excavation, but they are better consolidated than any of the younger formations except the local areas of travertine and heavily lime-cemented gravels. Their permeability is considerably lower than the younger sand and gravel but is equal to or slightly greater than the silt and clay of the Lake Bonneville group. Most of the tuff, sand, and clay will stand at high angles in fresh cuts. Weathered slopes are subject to minor slumping and sloughing. They appear to be adequate in excavations or as road foundations but their limited occurrence offers little opportunity to judge general foundation conditions.

Consolidated tuff and lava blocks, also probably of Tertiary age, are exposed only in the SW/4 sec. 2 , T. 5 
S., R. 1 W. These rocks are harder than any of those in the Jordan Narrows and stand in high-angle to vertical cuts without slumping.

\section{PALROZOIC FORMATIONS}

Paleozoic rocks (map symbol Pal, on pl. 2) form the mountains surrounding Utah Valley. Limestone and quartzite are abundant. They are generally very hard, dense, and massive except locally where they have been sheared and broken by faults. Locally along some of the major faults, the quartzitic formations have been pulverized to flour-size material.

Shale beds (Manning Canyon shale) are moderately extensive. They are commonly covered by several feet of overburden, because they erode and weather rapidly. A line of seeps and springs occurs where the shale is overlain by pervious rocks. Where water penetrates the shale along fault or bedding planes, or permeates the weathered overburden, the material becomes very unstable and steep natural or artificial slopes are liable to landslides and mudflows. Part of the irrigation canal along the front of the Wasatch Range was cut into beds of Manning Canyon shale; landsliding of these beds has moved this section of the canal more than $\mathbf{5 0}$ feet from its original alinement.

\section{CONSTRUCTION MATERIALS (UNPROCESSED)}

Unprocessed construction materials include those earth materials suitable for concrete aggregate, for fill, base course, or surfacing of highways, and riprap. The materials must be excavated and transported but they are used without further processing except for crushing, screening and (or) washing in order to obtain a desired sizing. Figure 14 shows the location of quarries and pits of various kinds in northern Utah Valley and figure 15 shows some of the different types of gravel.

BGNCH GRAVEL

Concrete aggregate.-Although most of the bench gravels, except the granite-bearing gravel along Dry Creek, have good physical and chemical soundness and generally acceptable roundness and grading, nearly all the deposits are considered unsuitable for concrete aggregate because of the prevalence of calcium carbonate deposited on and between the gravel pebbles. The coatings, which partly or entirely cover the pebbles, are enough to prevent good bonding of the cement even where the actual percentage of calcium carbonate may be very low.

Some of the high bench gravels near the mountain front and some of the Point of the Mountain deposits may have a sufficiently low percentage of lime to be acceptable for concrete aggregate but should be tested for other undesirable properties. For example, some gravels north of American Fork canyon which are composed of limestone, dolomite, hard shale, and quartzite show high losses in the dolomite and shale fractions under the sodium sulfate test ${ }^{1}$ indicating that they would give only fair resistance to freezing and thawing in the field.

Some of the gravel benches in front of the Lake Mountains contain more than 50 percent flat and elongate pebbles. Although this feature may be sufficiently serious to cause rejection for most concrete work, the gravels seem otherwise acceptable. Most of these deposits are largely free from the heavy lime coatings characteristic of the bench gravels on the east side of Utah Valley.

Surfacing and base course materials.-The bench gravels are widely used on the principal highways as base course under bituminous or concrete paving and as surfacing on secondary roads. They commonly require some screening to exclude oversize material (generally, that greater than $1 \frac{1 / 4}{4}$ inches in diameter). Some of the deposits close to the Wasatch Range contain a high percentage of very coarse gravel and large cobbles and, at present, commonly are avoided in favor of other deposits which require less crushing and screening. Farther from the mountains, the proportion of oversize material diminishes although in some places the bench gravels still lack enough sand and fine gravel to furnish the well-graded aggregate desired in construction. This deficiency in fines can be, and commonly is, corrected by running the material through a portable crushing and screening plant at the pit to obtain the required sizing.

Outcrops are numerous along stream valleys and gullies, and new gravel pits can be developed easily by sidehill excavation. In most places overburden is almost negligible, commonly ranging from a few inches on the slopes to a few feet of gravelly soil on the tops of the benches.

Fill.-The bench gravels form good pervious backfill. It is commonly necessary to add fines to make a satisfactorily stable embankment-type fill. The gravels require high moisture content, often complete saturation, to obtain maximum compaction.

Riprap.-Very little material in the bench gravels is suitable for riprap. Some of the large cobbles on the benches along the front of the mountains and along the railroad cuts in the SW $1 \frac{1}{4}$ sec. 25 , T. $4 \mathrm{~S}$., R. 1 W., east of Point of the Mountain may be suitable for riprap along railroad or highway embankments or on the downstream faces of earth dams. Some gravel layers at Point of the Mountain are so thoroughly limecemented that they form a hard rock that may be used for some types of riprap. Because of the disintegra-

\footnotetext{
1 Data furnished by Bureau of Reclamation field office at Pleasant Grove, Utah.
} 


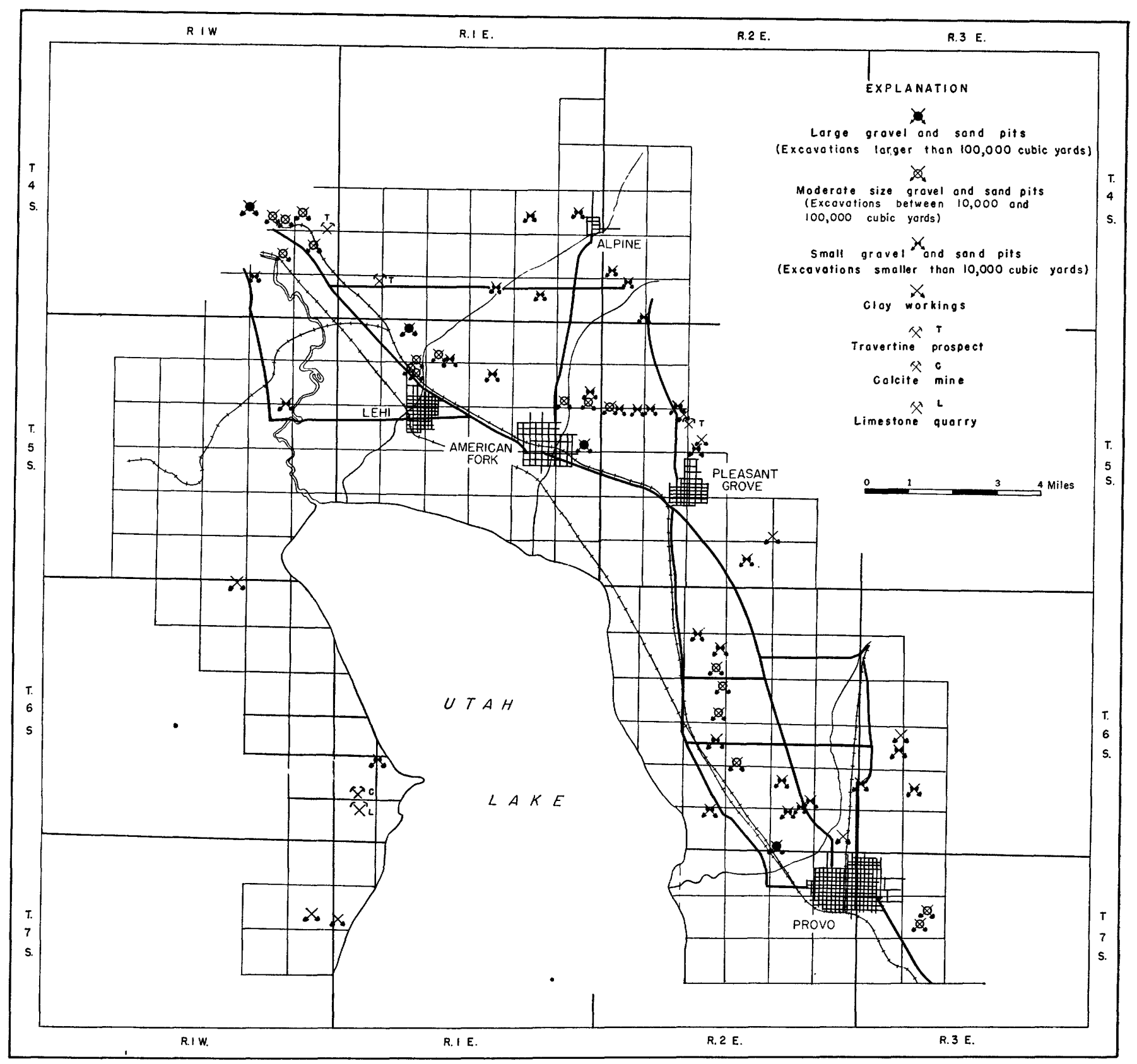

FIGURE 14.-Map showing location of pits and quarries in northern Utah Valley. 
GEOLOGY OF NORTHERN UTAH VALLEY, UTAF

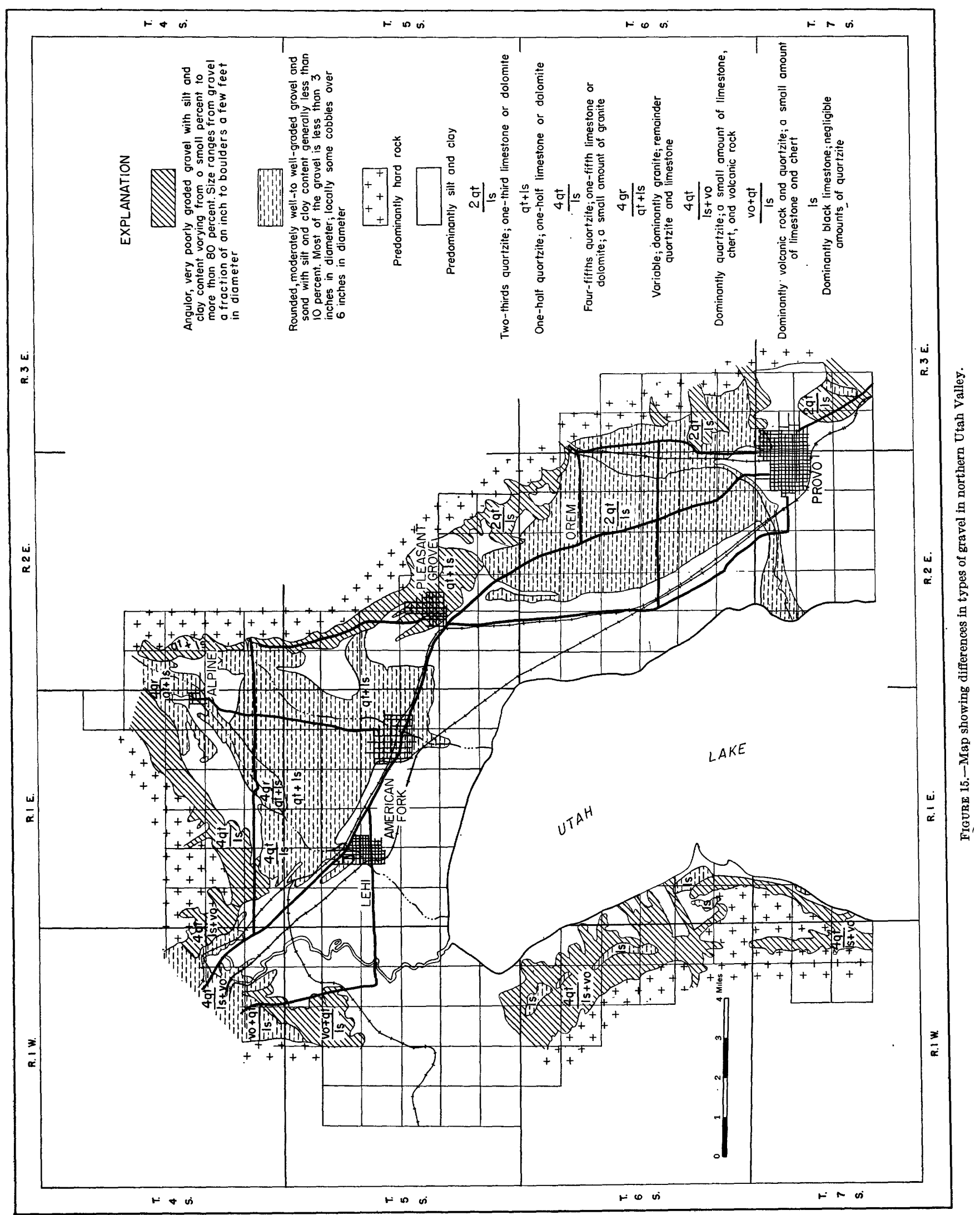


tion and solution of the lime cement, this material probably is not suitable for riprap which is in constant contact with water.

\section{RIVER GRAVEL}

Concrete aggregate.-The majority of the river gravel deposits contain hard, physically and chemically sound pebbles with very small quantities of deleterious minerals or harmful surface coatings and are considered suitable for concrete aggregate. In general these gravels contain enough silt and clay that they require washing before they can be used.

Most of the aggregate that has been used in construction requiring high-quality concrete work has come from the river gravel deposits. The largest operations are the pit now being worked by Owen Dean and Sons in the American Fork River channel (boundary between secs. 12 and 13, T. 5 S., R. 1 E.) and the pits which were opened nearby in the floodplain deposits (SW $14 \mathrm{SE} 1 / 4$ sec. 13 , T. .5 S., R. 1 E.) for the concrete construction at the Geneva Steel Co. plant.

The most satisfactory deposits are along American Fork River. They begin about a mile and a half southwest of the mountain front and extend roughly to the town of American Fork. In this zone the gravels carry lower percentages of cobbles, boulders, and oversize gravel than is found closer to the mountains, and do not contain the excessively high quantities of silt and clay that occur in the more southerly parts of the fan. The river-deposited gravels in the vicinity of Alpine have an appreciable percentage of decomposed granite pebbles and commonly are coated with a heavy deposit of calcium carbonate. The gravels of the Provo River contain considerable lime carbonate and commonly are overlain by 10 feet or more of silt and clay which would have to be removed by stripping.

Surfacing and base-course materials.-Most river gravel deposits are similar to the bench gravels in their suitability as coarse aggregate for surfacing or base course. The gravels along Dry Creek north of Alpine and the channel deposits of American Fork and Provo Rivers near the mountain front contain many large boulders and cobbles and require crushing and screening before they can be used.

Fill.-The river gravels can be used for pervious back fill. The deposits which lie a mile or more west of the mountain front probably contain enough intermixed or interbedded silt, clay, and fine sand to make stable embankment fill.

Riprap.-The coarse cobbles and small boulders in the river gravels near the mountain front along Provo River, American Fork River, and Dry Creek are suita- ble for light riprap. They have been used along irrigation ditches and canals. However, these deposits do not contain enough material of suitable size and shape to be of more than very local importance.

\section{MIXFD GRAVEL AND SAND}

Concrete aggregate.-The deposits of mixed sand and gravel are largely composed of sand and moderately to well-rounded rock and mineral fragments. Although the individual beds which range from a few inches to a few feet thick commonly are poorly graded, the average product of a working face in a pit from 10 to 30 feet high gives a moderately to well-graded aggregate.

The coarse fraction (retained on a no. 4 screen) generally comprises from 10 to 35 percent of the total and in size from $1 / 4$ to 2 inches, although scattered pebbles are larger. It varies in composition according to its source area in the mountains. The deposits east and south of Mitchells Hollow are composed almost entirely of hard, sound quartzite and limestone. West of Mitchells Hollow, the deposits contain some granite derived from the mountains at the head of Dry Creek. The granite commonly is decomposed and breaks up into separate mineral grains under pressure of the fingers. Most deposits contain less than 5 percent of granite but immediately west of Alpine some beds contain as much as 50 percent granite.

The fine fraction contains almost no clay-size fines and in some pits is deficient in material lying between the no. 30 and no. 200 sieve sizes. Except in the granite-bearing areas where feldspar sand grains are common, the particles are mostly subrounded quartz grains.

The principal objection to most of these deposits as a source of concrete aggregate is the prevalence of calcium carbonate cement in the upper 2 to 10 feet. Although this cement is much less abundant than in most of the gravel areas, there is enough to interfere with the good bonding desired for high-quality concrete work. A product made by mixing the cleaner lower beds with the coarser, lime-stained overlying layers is used locally for concrete in the construction of small buildings and appears to be satisfactory for this type of use.

Surfacing and base-course materials.-The mixed sand and gravel is a satisfactory material for highway construction. However the addition of some clay binder probably is desirable to make it more stable when used as gravel surfacing.

Fill.-These deposits are similar to the bench gravels in that they form good pervious backfill but are probably unsatisfactory in embankment fills without the addition of a clay and silt binder. 
SAND

Fine aggregate.-The wide changes in percentage of silt and clay admixed and interbedded with the sand results in considerable variation between deposits in suitability for fine aggregate.

Probably the best deposits are on the Highland bench north of Lehi (NW1/4 NE1/4 sec. 5, T. 5 S., R. 1 E.) and on the north end of the Orem bench. These deposits are predominantly clean loose quartz sand, although fragments of feldspar derived from the granite and carried in by Dry Creek are fairly common in the deposit north of Lehi. Both are generally overlain by limebearing gravel from a few inches to 1 or 2 feet in thickness, but apparently only small amounts of calcium carbonate remain in the sand. The sand north of Lehi has been used satisfactorily in small-scale concrete construction. Small pits have been developed in the Orem bench but no service records of the materials are available.

The sand ( $\mathrm{ss}_{2}$ on pl. 2 ) in the central part of the Highland bench appears to be unsuitable for use as fine aggregate because of the large percentage of silt and clay. The sand grains are predominantly less than $1 \mathrm{~mm}$ in diameter. The silt and clay mixed with the sand commonly average 15 to 35 percent of the total volume but in places constitute 70 percent.

The sand bars in front of the benches are composed chiefly of uniformly rounded, poorly graded quartz sand. The bar sands are moderately free from silt except near their tips at the north end of the Orem bench - and the west end of the Highland bench, where the silt content locally exceeds 25 percent. The silt-free parts of the sand bars have been used locally in concrete mixes for small house and garage foundations.

Surfacing and base-course materials.-The texture of . the sand deposits is too fine to be satisfactory for surfacing or use as base-course, but the sand is suitable for mixing with coarse aggregate.

Fill.-The silt-free sand could be used for pervious backfill but it would not be stable in embankment fills without addition of silt and clay for binder. Although not highly impermeable as a whole, the high-silt sand probably would make good fill if provision for adequate drainage is made during construction. The high-silt sand compacts fairly well and is moderately stable in embankment fills.

\section{SILT AND CLAY}

Fill.-Silt and clay commonly are used as fill and subgrade in many parts of Utah Valley and probably could also be used for puddle cores in earth dams. The silt-clay deposits can be highly compacted under optimum moisture content which is generally high (20 percent or more). Permeability of the compacted fill is low. The silt-clay deposits have relatively low shearing strength and require thorough compaction when used as embankments.

Binder material.- The silt and clay is useful as binder for coarse aggregate on gravel-surfaced roads.

UNSORTED MATERIALS (ALLUVLAL-FAN DEPOSITS)

Concrete aggregate, surfacing, and base-course.-The high percentage of silt and clay in most of the fan deposits render them unsuitable for concrete aggregate or for high-grade base-course and surfacing. The coarse fraction is generally composed of unsorted, angular rock fragments which could not be used without considerable washing, screening and crushing.

The fanglomerate benches a half mile east of Point of the Mountain ( $\mathrm{SE}^{1 / 4}$ sec. $24, \mathrm{~T} .4 \mathrm{~S} ., \mathrm{R} .1 \mathrm{~W}$.) may contain more suitable materials. They are composed largely of angular to subangular sand and small gravel with no more than a few percent of silt and clay. These deposits have not been worked commercially although they have been prospected at several places.

Fill.-The material in most of the fan deposits is suitable for backfill and embankment fill. The mixture of silt, clay, and rock compacts fairly well. The admixed rock fragments give it a considerably higher strength than a silt and clay fill. In general the alluvial fan material can be readily worked with power tools although locally large boulders and cobbles are numerous.

Riprap.-Local concentrations of boulders and cobbles along the shallow stream channels that cross the fans are a possible source of riprap. However the quantities of material of suitable size and shape are probably very limited.

\section{CONSOLDATED ROCKS}

TERTIARY FORMATIONS

The Tertiary formations crop out only in very limited areas, and they are unimportant as sources of construction materials. Furthermore, the rock types present are inferior in quality to most other materials available in the valley for concrete aggregate, base-course, or fill.

\section{PALEOZOIC FORMATIONS}

Concrete aggregate, base-course, surfacing, and fill.Quartzite and limestone in the mountains surrounding Utah Valley are generally hard and tough and would form sound aggregate material if crushed. These sources for crushed rock have not been used, however, because adequate supplies of clean rounded gravels are more accessible. Moreover, the quartzite especially tend to break into sharp angular fragments which would require a considerably higher proportion of cement than that needed to make workable concrete with more rounded aggregate. Although the granitic 
pebbles in the valley deposits commonly are much decayed, the fresh outcrops of granite along the head of Dry Creek probably would crush to make a firm satisfactory aggregate. The Manning Canyon shale has been used fairly successfully as fill.

Riprap.-The limestone, quartzite, and granite of the mountains are inexhaustible potential sources of riprap, but generally can be obtained only by blasting and quarrying. In some places, the talus from the bedrock would give a limited quantity of irregular blocks and fragments for such local construction as small check dams, but could not furnish a large supply of uniform quality material.

Limestone for flux. - In the $\mathrm{SW} 1 / 4 \mathrm{NE}^{1 / 4}$ sec. 31 T. $6 \mathrm{~S}$., R. 1 E. on the east flank of the Lake Mountains, limestone is being quarried and crushed for use as flux in iron and copper reduction.

Canal lining.-The Manning Canyon shale is the most satisfactory material in the area for lining irrigation canals to reduce water losses where the canals pass through highly porous deposits. The Bureau of Reclamation found that weathered shale mixed with soil not only sealed off pervious material faster than fresh shale but the admixed rock fragments of the overburden also acted to make the seal coat less easily eroded by the water.

\section{CONSTRUCTION MATERIALS (PROCESSED)}

Construction materials processed by some means other than washing and screening include the clay and shale deposits which furnish raw materials for the manufacture of house brick and low-grade refractories, and the calcareous tufa (travertine) east of Pleasant Grove which was used as a building stone in pioneer days.

\section{CLAY AND SHALE}

The deposits that have been the principal sources for clay in Utah Valley are of two kinds: beds of clay laid down in Lake Bonneville, and shale formations (Manning Canyon shale) in the older rocks that occur in the mountains bordering the valley.

Lake silt and clay.- The lake clays which overlie the gravels in and around the city of Provo are being used for brick by the Provo Brick and Tile Co. The company's pits are north of town (Fig. 14) in the NW/1/4E $\mathrm{SE}_{4}^{1 / 4}$ sec. 36 , T. 6 S., R. 2 E.

The clay ranges from lean to medium clay in composition. It turns pale yellow on firing and is satisfactory for ordinary building construction.

The distribution of this type of material is widespread throughout the valley. Mechanical analyses and simple testing for firing qualities could readily be made to determine new supplies as they are desired.
Some clay exposed in Dry Creek (NW $1 / 4 \mathrm{SE}_{34}^{1 / 4}$ sec. 34, T. 4 S., R. 1 E.) show a considerably higher percentage of clay minerals than usually occurs in the lake sediments. However, it appears to be of limited occurrence and would require stripping 6 to 15 feet of gravel and soil overburden.

Paleozoic shale.-Although a considerable amount of exploration has been done, no materials suitable for high-quality refractory brick and tile have been found in the north half of Utah Valley. However, the black shales that occur with the limestone and quartzite Paleozoic formations around the edge of the valley have refractory qualities and are being used as furnace lining in some of the smelters of Salt Lake Valley.

The largest shale pits are along the front of the Wasatch Range and Lake Mountains (fig. 14) and are accessible by road. The occurrence and size of these deposits are irregular because they occur in fault blocks in the midst of other fault blocks composed of limestone or quartzite beds. Generally the shale itself has been severely shattered and crushed by the faulting.

Most development has been by sidehill cuts. On steep slopes, the overburden is commonly lacking or at most is only a few inches thick. On gentle or flat slopes, the fresh shale is covered by a few feet or less of rocky soil and weathered shale. The shale can be removed readily by power shovels, bulldozers, or other power tools with little or no blasting required.

Clay developed on ancient soils.-A type of clay deposit discovered quite accidentally in connection. with this study may prove to be a useful source of raw material for brick and structural clay products. The data in this section are taken from a preliminary report by Hunt, Creamer, and Fahey (1949, pp. 120-122).

- The clay formed as an ancient soil prior to Lake Bonneville and is found only at those places where the land surface has been preserved since pre-Lake Bonneville time without being either eroded or buried by other sediments.

The ancient soil, where preserved in its entirety, is deep. The clay occurs in the upper part and in places is 10 feet thick. Beneath the clay is another 20 to 30 feet of strongly lime-enriched weathered parent material, the top of which would form the bottom of pits that might be opened in the clay. The clay comprising the upper layer of the old soil is practically free of lime but does contain considerable iron-oxide. The clay mineral is believed to be largely illite but much more study of the mineralogy is needed before any generalizations can be made regarding the mineral or chemical composition of the deposits.

The texture of the clay, or its content of sand aggregate varies considerably, depending on the kind of parent rock from which the old soil was formed. The 
soil is known to have formed on limestone, shale, granitic rocks, lavas, and mixtures of these. The parent rocks except for their quartz or other resistant minerals were completely altered to clay by the soilforming process. Where, for example, the soil developed on a shale formation, very little sand aggregate remains and more than 90 percent of the clay can be washed through a 325-mesh sieve. Where the soil developed on gravel or other deposits containing much quartz this material remains with the clay. Sixty to seventy percent of this kind of clayey material can be washed through a 325-mesh sieve. Depending on the proportion of aggregate desired in the clay, prospecting would be guided by the kind of parent rock under these upland surfaces.

Three samples of the clay were tested by the National Bureau of Standards (Hunt, Creamer, and Fahey, 1949, p. 121):

Sample A. Old clay soil developed on the oldest of the glacial moraines, above Alpine. Parent morainal material largely granitic; mica content of clay 5 to 10 percent. Sample taken by auger 18 to 36 inches below surface.

Sample B. Old clay soil on fanglomerate composed of granite, latitic lava, limestone, and quartzite gravels. Sample from near reservoir in Traverse Mountains 2 miles northwest of Alpine. Sample from 12- to 48-inch depth.

Sample C. Old soil formed on Manning Canyon shale. South side of Provo Canyon, by Pole Canyon road 2 miles from Provo Canyon road.

These three clays were found to have properties suitable for the manufacture of common brick and structural clay products with a maturing range from about $1000^{\circ}$ to $1075^{\circ} \mathrm{C}$. (approximately $1830^{\circ}$ to $\left.1960^{\circ} \mathrm{F}\right)$.

The results of a sieve analysis are given in the following table:

\begin{tabular}{|c|c|c|c|c|}
\hline Sample No. & $\begin{array}{c}\text { Retained } \\
\text { on 100- } \\
\text { mesh sieve }\end{array}$ & $\begin{array}{l}\text { Retained } \\
\text { 200-mesh } \\
\text { sieve }\end{array}$ & $\begin{array}{c}\text { Retained } \\
\text { on 325- } \\
\text { mesh sieve }\end{array}$ & $\begin{array}{l}\text { Passing } \\
\text { 325-mesh } \\
\text { sieve }\end{array}$ \\
\hline $\begin{array}{l}\mathrm{A} \\
\mathrm{B} \\
\mathrm{C}\end{array}$ & $\begin{array}{l}\text { 19. } 2 \\
11.15 \\
3.9\end{array}$ & $\begin{array}{r}8.2 \\
10.3 \\
1.0\end{array}$ & $\begin{array}{l}\text { 6. } 5 \\
9.15 \\
2.2\end{array}$ & $\begin{array}{l}66.1 \\
69.4 \\
92.9\end{array}$ \\
\hline
\end{tabular}

The material which passed through the 325-mesh sieve was used for making one set of test bars and for the determination of the water of plasticity. The test bars were dried at $110^{\circ} \mathrm{C}$. They were measured for 24773-54-5 drying shrinkage previous to being heated to $1000^{\circ} \mathrm{C}$. in an electric furnace. The results are tabulated below.

\begin{tabular}{|c|c|c|c|c|}
\hline Sample No. & $\begin{array}{c}\text { Shrinkage } \\
\text { during } \\
\text { drying } \\
\text { (percent) }\end{array}$ & $\begin{array}{l}\text { Total } \\
\text { shrinkage at } \\
1000^{\circ} \mathrm{C} \text {. } \\
\text { for } 1 \mathrm{hr} \\
\text { (percent) }\end{array}$ & $\begin{array}{l}\text { Color after } \\
\text { heating }\end{array}$ & $\begin{array}{l}\text { Water of } \\
\text { plasticity } \\
\text { (percent) }\end{array}$ \\
\hline $\begin{array}{l}\text { A. } \\
B_{-} \\
C_{-}\end{array}$ & $\begin{array}{r}8.4 \\
9.2 \\
-\end{array}$ & $\begin{array}{l}13.2 \\
12.5 \\
10.2\end{array}$ & $\begin{array}{l}\text { Brown-red. } \\
\text { Brown-red.- } \\
\text { Salmon. }\end{array}$ & $\begin{array}{l}29.2 \\
26.1 \\
29.4\end{array}$ \\
\hline
\end{tabular}

Some of the clay was used without sieving to make a second set of test bars. These bars were heated to $1100^{\circ} \mathrm{C}$. for one hour.

\begin{tabular}{r|r|l}
\hline Sample No. & $\begin{array}{r}\text { Fired } \\
\text { shrinkage at } \\
1100^{\circ} \mathrm{C} . \\
\text { for 1 hr } \\
\text { (percent) }\end{array}$ & Color \\
\hline & $\begin{array}{r}7.5 \\
7.1\end{array}$ & $\begin{array}{l}\text { Dark red-brown. } \\
\text { Do. } \\
\text { Dark red. }\end{array}$ \\
\hline
\end{tabular}

Because the deposits are remnants of a land surface that has been modified by erosion, their size and shape vary widely. The thickest and most extensive deposits occur on smoothly rounded upland surfaces where several feet of clay may extend over several acres. Some individual deposits already known contain many tens of thousands of cubic yards of clay.

The clay occurs at the surface with no more than a few inches of recent rubble or humus above the clay. Hand augers are adequate for determining the quality, extent, shape, and thickness of a deposit.

In general the lime-rich zone that is beneath the clay and that would form the floor of a pit is undulatory and slopes toward the present valleys. Rarely can a level floor be expected under these clay deposits. The slope of the floor, however, generally is less steep than the present land surface so the deposits generally thicken in a direction away from the present valleys.

One of the most accessible deposits is found in the eastern part of the Traverse Mountains immediately northwest of Alpine. This clay contains considerable aggregate, in part pebbly. It was developed from gravel deposits containing pebbles of limestone, quartzite, granite, and latitic lavas. Similar high-aggregatebearing clays that form directly on bedrock formations of limestone, quartzite, and latitic lavas occur in the western part of the Traverse Mountains; other deposits occur in the Wasatch Range. 


\section{CALCAREOUS TUFA (TRAVERTINE)}

During the early settlement of Utah Valley, many homes and farm buildings were constructed of calcareous tufa quarried from a hillside northeast of Pleasant Grove in the $\mathrm{NE}^{1} / 4 \mathrm{NE}^{1} / 4$ sec. 17 , T. $5 \mathrm{~S}$., R. $2 \mathrm{E}$. The tufa is a spring deposit formed by the cementation of fragments of Paleozoic shales, pre-Lake Bonneville fanglomerate, and probably some younger materials into a relatively solid, hard calcareous rock. The tufa is referred to locally as "pot stone" or "pot rock."

The tufa is very porous and, when first quarried, is soft enough to be trimmed and shaped with an axe but it hardens rapidly on exposure. It appears to be durable for light construction under the semiarid climate of Utah Valley. Some of the older houses which have been standing 80 years or more show only slight effects of weathering. Because it is highly vesicular, the tufa would not be suitable for foundation material in continuously wet ground.

The largest exposure of tufa is a few hundred yards square. About half the deposit has been removed. However, little or no tufa-block construction has been done in the valley in the last 50 to 60 years since brick became cheap and plentiful.

\section{CALCTTE}

A small mine, in the $\mathrm{SE} 1 / 4 \mathrm{SW} 1 / 4$ sec. 30 T. 6 S., R. $1 \mathrm{E}$. on the east edge of the Lake Mountains, has been opened in a calcite vein 8 to 15 feet wide. The bedrock bordering the vein is dense black limestone. Part of the material is removed by an open cut extending along the vein. Underground operations are also being used to work the deeper parts of the deposit.

The calcite is coarsely crystalline and is cloudy white to light gray. No large crystals of optical quality have been found. The calcite is run through a crusher at the mine and is used in chicken feed.

\section{SEISMIC ACTIVITY IN UTAF VALLEY}

Utah Valley has been, and no doubt will continue to be, an active seismic area. Heavy construction needs to consider and safeguard against the possibility of earthquakes.

Except near the extreme margins of the valley, the foundations of all construction must necessarily be in unconsolidated silt, sand, and gravel. Such materials are probably the most undesirable medium for heavy construction in seismically active areas because the effective intensity of earthquake waves propagated through unconsolidated sediments is far greater than in solid rock.

Earthquakes of varying intensity have been recorded in Utah since the earliest days of settlement. Informa- tion in this report regarding the history of earthquakes was furnished by J. Stewart Williams, Utah Agricultural College, Logan, Utah. Prior to the installation of the seismograph at the University of Utah in 1907, there was no instrumental record, but the Deseret News has provided good descriptions of nearly all earth tremors affecting the State since 1853. At least 123 different earthquakes have occurred in Utah since that date; 34 of them apparently centered along the front of the Wasatch Range and some of these affected Utah Valley.

Earthquakes having intensities as great as IX (Rossi-Forel scale) and affecting tens of thousands of square miles have occurred in other parts of Utah. But most tremors that apparently centered along the front of the Wasatch had intensities from III to V; six had intensities between V and VII. The highest recorded in Utah Valley is $\mathrm{V}$, but it should be recalled that these records cover less than 100 years.

\section{WATER RESOURCES \\ By Harold E. Thomas \\ INTRODUCTION}

Water and productive soils constitute the natural resources of preeminent importance to Utah Valley. Because there is far more arable land than can be irrigated from available water supplies-a characteristic common to most of the intermontane areas in the arid West-water is the limiting factor in the agricultural economy which has dominated the area since the first Mormon pioneers entered the valley in 1849 . Water is also one of the major factors that will determine the pattern and set the limit to the currently expanding industrial development and to the growth of communities to service those industries. Utah Valley is fortunately situated where it can harvest the water crop of tributary drainage basins that include high mountains with abundant precipitation. So productive are these drainage basins that in comparison with adjacent areas the valley is exceptionally well provided with water, and a surplus accumulates in Utah Lake which is appropriated by water users in Jordan Valley to the north.

Utah Valley is a part of the drainage basin of the Jordan River, which extends over five counties (Salt Lake, Utah, Juab, Wasatch, and Summit) and includes more than half the population of Utah. The Jordan is first among the drainage basins of the State in quantity of surface water utilized for irrigation and other purposes. It also leads the State in the number of wells and in the quantity of ground water discharged from wells and springs.

The northern part of Utah Valley is, in several respects, a distinctive part of the Jordan River drainage 
basin. The largest stream in Utah Valley, the Provo River, is also the largest contributor to the Jordan River system. American Fork River is the third largest tributary in the system. Several of the minor streams have less seasonal variations in flow than is common in most streams in Utah. Battle Creek near Pleasant Grove furnishes water on a schedule that is nearly ideal for irrigators, the discharge coming from springs that probably are fed from high snow fields on Mount Timpanogos and that reach their maximum discharge in the latter part of the irrigation season, long after the freshets of most streams. Excellent wells are also obtained in northern Utah Valley, and the average discharge per well is higher than in any other major ground-water reservoir in the State.

Because there were few water-shortage problems, and because the ground-water reservoir seemed inexhaustible to them, early settlers saw no need for determining the occurrence, movement, or quantity of water available for utilization. There is, therefore, very little factual information concerning the water supply during the first half-century of development. Even today there are continuous records of discharge for only the larger streams. For several smaller streams, diversions are made on an established fractional basis, without knowledge of the quantity being discharged by the stream.

Far less is known about the ground-water supplies, and particularly the close relationship between groundwater and surface-water supplies. Practically no data concerning wells were collected during the first 85 years of settlement. After the enactment of a groundwater law in 1935, the Utah State Engineer obtained from well owners records concerning the depth, diameter, date of completion, use, and estimated yield of each well then in existence, and since that year similar information on new wells has been required as part of the proof of appropriation of water. During the years 1937 to 1940 measurements of discharge from wells were made by the State Engineer in cooperation with the Federal Works Projects Administration. Quantitative hydrologic studies to show the source, movement, and discharge of water in individual aquifers have not yet been made.

\section{HISTORY OF WATER UTILIZATION}

\section{DIVERSIONS FROM STREAMS}

USE OF WATER PRIOR TO 1880

According to Stover (1903, p. 93):

Soon after their settlement in Great Salt Lake Valley in 1847, the Mormon pioneers began the systematic settlement of other nearby valleys $* * *$. In the spring of 1849 a number of families, under the direction of the church, entered Utah Lake Valley. Thirty families located on Provo River about 2 miles west of the present site of Provo City, and others settled near the present sites of Lehi, American Fork, and Pleasant Grove, on the streams which emerge from the mountains near those points $* * *$. Each year the amount of land brought under cultivation was rapidly increased and settlement extended to different parts of the valley. Soon the tide of settlement turned toward the smaller valleys lying on the tributary streams.

In 1858 the first settlement was made on the upper reaches of the Provo River, in Heber Valley east of the Wasatch Range.

The early history of the diversions from the tributaries to northern Utah Valley, the apportionment and use of the water, and the development of water rights, have been described by Stover (1903, pp. 107-144). The following tabulation summarizes the history of the principal stream diversions in the area prior to 1880 , based largely on his report. (See table 16.)

TABLE 16.-History of principal stream diversions prior to 1880 in northern Utah Valley

\begin{tabular}{|c|c|c|c|c|c|}
\hline Stream & Diversion & $\begin{array}{c}\text { Con- } \\
\text { struc- } \\
\text { tion } \\
\text { began } 1\end{array}$ & $\begin{array}{c}\text { Water } \\
\text { di- } \\
\text { verted } 1\end{array}$ & $\begin{array}{l}\text { Area } \\
\text { reported } \\
\text { entitled } \\
\text { to water } \\
\text { (acres) } 1\end{array}$ & $\begin{array}{c}\text { Area } \\
\text { decreed } \\
\text { entitled } \\
\text { to water, } \\
1921 \\
\text { (acres) }\end{array}$ \\
\hline Provo River & $\begin{array}{l}\text { Little Dry Creek } \\
\text { Provo city irrigation: } \\
\text { East Union } \\
\text { Factory race. } \\
\text { City race } \\
\text { Tanner race. } \\
\text { Provo Municipal. }\end{array}$ & $\begin{array}{l}1850 \\
1850 \\
1856 \\
1856 \\
1856\end{array}$ & 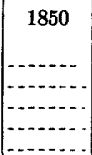 & $\begin{array}{r}440 \\
31,200 \\
3380 \\
3500\end{array}$ & 2,559 \\
\hline - & $\begin{array}{l}\text { Lake bottom } \\
\text { River bottom: } \\
\text { East of river } \\
\text { Park \& Nuttali } \\
\text { Barton \& Young. } \\
\text { Fort Field. } \\
\text { Spring Creek. } \\
\text { Provo Bench } \\
\text { Upper East Union. } \\
\text { West Union } \\
\text { Alta. } \\
\text { Timpanogos }\end{array}$ & $\begin{array}{l}1856 \\
\\
1862 \\
1870 \\
1872 \\
1875 \\
1878\end{array}$ & $\begin{array}{l}1864 \\
1871 \\
1876 \\
1875 \\
1879\end{array}$ & $\begin{array}{r}6,000 \\
\\
900 \\
\\
4,000 \\
700 \\
3,500 \\
300 \\
650\end{array}$ & $\begin{array}{r}1,275 \\
362 \\
81 \\
56 \\
574 \\
352 \\
4,332 \\
854 \\
1,880 \\
847\end{array}$ \\
\hline $\begin{array}{l}\text { American Fork } \\
\text { River. }\end{array}$ & $\begin{array}{l}\text { Lehi Irrigation } \\
\text { American Fork } \\
\text { Pleasant Grove }\end{array}$ & $\begin{array}{l}1851 \\
1851 \\
1851\end{array}$ & $\begin{array}{l}1851 \\
1851 \\
1851\end{array}$ & $\begin{array}{r}46,700 \\
6,000 \\
55,000\end{array}$ & $\cdots$ \\
\hline $\begin{array}{l}\text { Dry Creek } . . . . . \\
\text { Battle Creek...... } \\
\text { Grove Creek..... }\end{array}$ & $\begin{array}{l}\text { Lehi Irrigation } \mathrm{Co} \\
\text { Alpine } \\
\text { North Bench } \\
\text { Pleasant Grove }\end{array}$ & $\begin{array}{l}1850 \\
1851 \\
1877 \\
1851 \\
1851\end{array}$ & 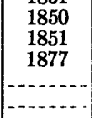 & $\begin{array}{c}(1) \\
1,800-2,000 \\
1,200 \\
(5) \\
(5)\end{array}$ & 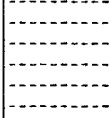 \\
\hline
\end{tabular}

1 From U. S. Dept. Agr. Bull. 124, pp. 107-144, 1903.

2 From Provo River decree, civil case 2888, 4th district court.

3 Estimated

Diversions from American Fork River and Dry Creek used to irrigate 6,700 acres. $\checkmark$ Diversions from American Fork River supplemented by entire flow of Battle and Grove Creeks.

By 1880 almost the entire low-water flow of the several streams was being diverted, and the list above is therefore a nearly complete list of the principal diversions that have established primary rights to the streams of northern Utah Valley.

Under an act passed February 20, 1880, water rights were divided into classes. All rights to the use of a stream acquired up to the time that the sum of the rights is equal to the ordinary low-water flow of the stream are "primary" rights, and 7 years' continuous use gives a primary right. Those acquiring rights to water after the low-water flow is exhausted, or who use 
water during flood flows, have "secondary" rights. In times of scarcity holders of secondary rights receive no water, and whatever water a stream furnishes is divided among holders of primary rights pro rata according to their respective rights, which are based in part on the area irrigated and in part on a ratio fixed by the court that defined the rights to the stream. This law carries the classification no further, but some subsequent court decisions carry the principle further and divide the rights to a single stream into several classes. In such cases the first class receives the water it needs; if there is enough water the second class takes what it needs, and so on until a class is reached for which there is not enough water. All classes below this get no water, and the remaining water not needed by higher classes is divided pro rata among the holders of rights in the class in which there is a shortage. Thus priorities have been established by group rather than by individual rights.

Prior to 1880 the water supply furnished by the Provo River had been adequate for the needs of all. In American Fork River and Dry Creek, however, the late-summer flows were commonly inadequate for all users, and disagreements as to division of the flow arose as early as 1874. During the period prior to 1880 diversions from the Provo River were being increased in upstream areas east of the Wasatch Range (Heber Valley and Kamas Valley), and by 1881 the entire low-water flow of the river was being diverted in those valleys for irrigation.

\section{STATUS IN 1909}

By 1903, methods for apportionment of the flow of each of the larger streams entering northern Utah Valley had been established by court decisions. For American Fork River a decision of the Stake High Council of the Church in 1879 became the basis on which water was divided. The First District Court of the Territory in 1892 decreed the basis for proration of the waters in Dry Creek. For the Provo River in Utah Valley a decree of the Fourth District Court in January 1902 (the "Morse" decree) stated that no apportionment was necessary as long as the river's flow was sufficient to fill the canals to their full carrying capacity as then constructed (about $370 \mathrm{cfs}$ ) and specified the basis for apportionment of lesser flow. The water rights on the upper reaches of the Provo River, which had been adjudicated by the same court in May 1899 (the "Fulton" decree), were not associated with or to any extent involved in the controversies over water rights on the river in Utah Valley. The rights on the two divisions were considered separate and in no way related to each other.
With respect to the Provo Rirer, Stover (1903, pp. 134-135) drew the following conclusions from his studies in 1900:

(1) That owing to the varying nature of water rights of the several canal interests deriving their supply of water from Provo River below the mouth of the canyon, and also since the Utah law provides that there shall be no priority among primary rights, the system of prorating the flow of the stream is very satisfactory, and is one to be commended. Steps, however, should be taken toward attaining greater accuracy in the measurement of the flow in the several canals, either by measuring weirs constructed on scientific principles or, better still, measuring flumes which have been carefully rated.

(2) That the method of distributing water from main canals on the time basis in localities where farms are comparatively small is conducive to a high duty of water.

(3) That there is an unnecessary waste of water, both in its distribution and in its subsequent use on the irrigated land, but that this waste is caused rather by the ignorance of efficient methods of distribution and use of water than by willful negligence on the part of the irrigator, and that by experience and study of existing conditions the irrigator will see the defect and take steps toward remedying it.

(4) That under the majority of Provo River canals entirely too much water is used. And along this same line it may be said that all measurements made during the season of 1900 go to show that in proportion to the amount of land irrigated the amount of water allotted to the river-bottom ditches is out of all proportion to the amount allowed the larger canals on either side of the river.

(5) That during the season of 1900 , although complaint was made of shortage of water supply, the amount of water discharged by the Provo during the irrigation season, had it been apportioned properly, would have been adequate for the needs of all.

(6) That during the latter part of the irrigation season the supply of water in the lower reaches of Provo River is materially increased by return seepage from irrigated lands lying on the upper reaches of the stream, on which a generous amount of water is used during the early part of the season; and that in the absence of storage reservoirs, in which to store the surplus water of the river during the spring months, this use of water in the upper valleys should be encouraged.

(7) That the use of irrigation streams for the development of power, when such use in no way interferes with the use of the water for irrigation, is beneficial and should be fostered, as a direct means of bringing about the development of the State. However, where the use of water for power purposes is detrimental to the development and growth of an irrigation section. the use of water for irrigation should take precedence.

The State Legislature in May 1903 enacted statutes that declared stream waters to be public property subject to appropriation on the basis of priority, designated the State Engineer as the officer responsible for administration of water laws, and required subsequent appropriators to submit applications and proofs of appropriation to the State Engineer. Rights established prior to the passage of these statutes-which are commonly called "diligence" rights-were not required to 
be recorded, but many of these rights have been defined in decrees adjudicating the rights of individual river basins, and others have been recorded in court decisions resulting from litigation over water rights.

STATUS IN 1947

Developments since 1903 have resulted in greater utilization of the water of the Provo River and to a lesser extent the water of other tributaries to northern Utah Valley, and have increased the water available to the valley by diversion from the Weber River drainage basin when there is a surplus. Building of dams to regulate the levels and permit storage in the headwater lakes of the Provo River was begun in 1905, and construction of canals to divert water from Beaver and Shingle Creeks (tributaries of the Weber River) was begun in 1906. Completion of the Deer Creek Reservoir in 1941 by the U. S. Bureau of Reclamation provided ample storage facilities for the water diverted from other drainage basins, as well as for surplus water of the Provo River when Utah Lake is at high stage. Because of this, it was possible to fulfill the requirements for water of the Defense Plant Corporation's Geneva Steel plant during the war emergency without hardship to other users of water.

The waters of the Provo River were adjudicated in 1921 by a decree which, in the language of the presiding judge, Hon. C. W. Morse, was "the first litigation made on the basis of the physical unity of the stream from its headwaters to its mouth." This decree still forms the basis upon which water is distributed throughout the river system. With respect to Utah Valley (the "Provo division" of the river) the decree recognizes all rights established prior to May 1903 (the "diligence" rights) as primary or "Class A" rights, and awards to these rights the natural flow of the river up to an amount ranging from $291 \mathrm{cfs}$ between May 10 and June 20, to $209 \mathrm{cfs}$ between January 15 and May 10. Rights acquired by application to the State Engineer subsequent to May 1903 were grouped in nine classes (classes $B$ to $J$ in order of priority), and it was decreed that water should be distributed to classes in order of priority, and that whenever there is insufficient water to meet the needs of a class pro-rata distribution is made within that class, and classes of lower priority receive no water. Exceptions to this rule are stored water in headwater lakes, water diverted from other drainage basins, and water used for power, which is recognized as "additional" use.

With respect to the effect of irrigation in Kamas and and Heber Valleys upon the stream flow available to Utah Valley, the court found that late-summer flow in the lower part of the river was "greatly in excess" of that in earlier times, and concluded that irrigation in the upper (Wasatch) division was responsible. The decree therefore defined the order of priority of water rights as between divisions, giving general priority to the established water rights in the Wasatch division as against all classes in the Provo division, particularly in early-season use.

The 1921 decree, although it adjudicated the rights to the flow of the Provo River, made no attempt to adjudicate ground-water rights in that drainage basin, or to define the rights of Utah Lake water users, who are dependent upon the Provo River drainage basin for a large part of their water supply. Accordingly, an adjudication of all water rights in the Jordan River drainage basin was called for in the suit of Salt Lake City et al. v. Tamar Anderson et al., filed in May 1936. Subsequently, the court placed this matter in the hands of the State Engineer, charging him with preparing a proposed determination of all rights within the drainage basin. In addition to the important surface-water rights involved, there was also to be taken into consideration the determination of the rights to the use of ground water within the area. This determination was still in progress in 1947.

\section{DEVELOPMENT OF WELLS}

EARLY HISTORY

It is presumed that wells were dug very soon after the first settlers arrived in Utah Valley, especially where streams, springs, or irrigation ditches could not be relied upon for a continuous flow of uncontaminated water. No records have been found concerning these early wells, and very few of the dug wells now in existence were constructed prior to 1880 . In recent years many dug wells have been abandoned as community water systems have been developed and extended, and it is likely that the earlier development of municipal water systems by the larger towns, and of artesian wells in outlying areas, likewise resulted in abandonment of large numbers of the old wells that were dug by the original settlers.

The history of development of flowing wells in the northern part of Utah Valley is somewhat better documented. James Harwood of Lehi, in a letter dated April 1891 to the U. S. Census Bureau in Washington, stated that he had driven the first artesian well in Utah County with sledge hammers about 6 years earlier, using 11/4-inch pipe with a steel point on the end, the pipe perforated at 75 feet. He obtained a flow of $4 \mathrm{gpm}$, which continued for about 3 years and then ceased as other wells were driven at lower altitudes.

After the census of 1890, questionnaires were sent to owners of artesian wells in Utah Territory, and replies 
of the residents in northern Utah Valley described 115 artesian flowing wells. About 75 of these wells were in the vicinity of Lehi, 15 each near Pleasant Grove and Lake View, and the remainder in the vicinity of Provo. Practically all were constructed of 13/4-inch to 2-inch pipe, in many instances limited to the upper few feet of the well, with open hole below-a practice that was recognized at that time to result in sanding of the well and failure of the supply. Artesian flows were obtained at depths of 40 to 200 feet, the lesser depths being especially common in the vicinity of Lehi. Only 10 of the 115 wells had depths reported to exceed 150 feet.

\section{STATUS IN 1903}

Richardson (1906, pp. 36, 59-75) in the fall of 1904 included in his list of typical wells about 300 in northern Utah Valley, but did not attempt a complete listing. He estimated that there were at that time about 5,000 flowing wells in Jordan River and Utah Lake valleys, of which more than half were in Utah Lake valley.

The ground-water law of 1935 required the owners of wells constructed prior to the enactment of the law to file claims for those wells that would set forth information essential to determination of water rights. According to the claims for northern Utah Valley, about a thousand of the wells in existence in 1935 had been constructed prior to 1903 , and another thousand were completed between 1903 and 1931. Of the wells drilled prior to 1903 , about 75 percent were located in the northern part of the area (the Highland district, see below) near the towns of Lehi, American Fork, and Pleasant Grove.

\section{STATUS IN 1947}

By the beginning of 1947 there were about 2,285 wells in use in the northern part of Utah Valley, according to tabulations of the State Engineer. In addition, 505 wells were listed for which no use was claimed by the owners, many of which had been plugged or filled with debris; also, 105 wells drilled by the Salt Lake City Corp. in 1889 to augment water supplies in Jordan Valley had remained capped and unused since 1890 by order of the District Court, which found that those wells interfered with adjacent wells having prior rights.

As shown in more detail in table 17 below, most of the wells in use in 1947 were flowing wells less than 200 feet deep used primarily for irrigation, and to supplement domestic and stock requirements. Most of the wells were 2 inches or less in diameter but the more productive irrigation wells were larger, commonly 4 inches in diameter.
Table 18 shows the cumulative total of wells in northern Utah Valley, based on claimed dates of completion as filed in the office of the State Engineer. These totals do not agree exactly with those in table 17 , because some wells have been abandoned since the claims were filed in 1935, and because on some claims the date of construction is not stated. Wells that were constructed and subsequently abandoned are not included in either listing if the abandonment was prior to 1935 .

Hydrologic studies, which are discussed in more detail subsequently, have shown that the northern part of Utah Valley may be logically subdivided into three ground-water districts: the Provo district, comprising the alluvial and delta deposits of the Provo River and minor tributaries to the south; the Highland district, consisting chiefly of the alluvial and delta deposits of American Fork and Dry Creek, but including also the fans of Grove and Battle Creeks; and the Lake district, west of the Jordan River.

The Provo district includes all the area between Utah Lake and the Wasatch Range south of the boundary between Tps. 5 and 6 S., Salt Lake base and meridian. The Highland district extends north of that boundary to the base of the Traverse Mountains and west to the Jordan River. The Lake district, in which there has been very little ground-water development, embraces the area west of the lake and Jordan River.

TABLE 17.-Classification of wells in northern Utah Valley in 1947

[Based on claims and applications in State Engineer's office]

\begin{tabular}{|c|c|c|c|}
\hline & $\begin{array}{l}\text { Highland } \\
\text { district Tps. } \\
4 \text { and } 5 \mathrm{~S} \text {. }\end{array}$ & $\begin{array}{c}\text { Provo district } \\
\text { Tps. } 6 \text { and } \\
7 \mathrm{~S} \text {. }\end{array}$ & Total \\
\hline 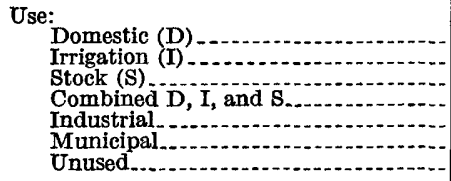 & $\begin{array}{r}37 \\
263 \\
28 \\
835 \\
17 \\
12 \\
314\end{array}$ & $\begin{array}{r}46 \\
296 \\
31 \\
680 \\
31 \\
8 \\
296\end{array}$ & $\begin{array}{r}83 \\
559 \\
59 \\
1,515 \\
48 \\
20 \\
610\end{array}$ \\
\hline Total reported... & 1,506 & 1,388 & 2,894 \\
\hline 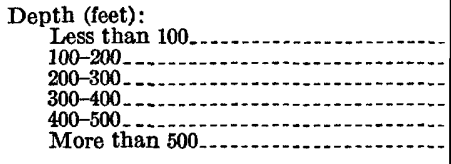 & $\begin{array}{r}237 \\
805 \\
162 \\
63 \\
5 \\
5 \\
\end{array}$ & $\begin{array}{r}87 \\
662 \\
150 \\
21 \\
16 \\
6 \\
\end{array}$ & $\begin{array}{r}324 \\
1,467 \\
312 \\
84 \\
21 \\
11 \\
\end{array}$ \\
\hline Total reported..... & 1,277 & 942 & 2,219 \\
\hline $\begin{array}{l}\text { Diameter (inches): } \\
\text { Jetted or driven: } \\
2 \text { or less } \\
212-3,2 \\
312-4 \\
412-5 \\
\text { Drilled or jetted; more than } 5 \\
\text { Dug }\end{array}$ & $\begin{array}{r}829 \\
142 \\
190 \\
37 \\
23 \\
78\end{array}$ & $\begin{array}{r}458 \\
231 \\
229 \\
79 \\
48 \\
44\end{array}$ & $\begin{array}{r}1,287 \\
373 \\
419 \\
116 \\
71 \\
122\end{array}$ \\
\hline Total reported..... & 1,299 & 1,089 & 2,388 \\
\hline Flowing wells_._. & 1,113 & 879 & 1,992 \\
\hline
\end{tabular}


TABLE 18.-Number of wells in northern Utah Valley by years

\begin{tabular}{|c|c|c|c|c|c|c|c|c|c|c|c|}
\hline Year & \begin{tabular}{|l} 
High- \\
land \\
dis- \\
trict
\end{tabular} & $\begin{array}{l}\text { Provo } \\
\text { dis- } \\
\text { trict }\end{array}$ & Total & Year & $\begin{array}{l}\text { High- } \\
\text { land } \\
\text { dis- } \\
\text { trict }\end{array}$ & $\begin{array}{l}\text { Provo } \\
\text { dis- } \\
\text { trict }\end{array}$ & Total & Year & $\mid \begin{array}{l}\text { High } \\
\text { land } \\
\text { dis- } \\
\text { trict }\end{array}$ & $\begin{array}{l}\text { Provo } \\
\text { dis- } \\
\text { trict }\end{array}$ & Total \\
\hline 30. & $\begin{array}{l}1 \\
1 \\
1 \\
1 \\
1\end{array}$ & $\because$ & $\begin{array}{l}1 \\
1 \\
1 \\
1 \\
1\end{array}$ & $\begin{array}{l}1890 \\
1891 \\
1892 \\
1893 \\
1894\end{array}$ & $\begin{array}{l}271 \\
277 \\
284 \\
301 \\
306\end{array}$ & $\begin{array}{l}44 \\
44 \\
49 \\
50 \\
53\end{array}$ & $\begin{array}{l}315 \\
321 \\
333 \\
351 \\
359\end{array}$ & $\begin{array}{l}1920 \ldots \\
1921- \\
1922- \\
1923 . \\
1924 .\end{array}$ & $\begin{array}{l}1,082 \\
1,087 \\
1,092 \\
1,105 \\
1,114\end{array}$ & $\begin{array}{l}659 \\
674 \\
687 \\
706 \\
723\end{array}$ & $\begin{array}{l}1,731 \\
1,761 \\
1,779 \\
1,811 \\
1,837\end{array}$ \\
\hline 68.- & $\begin{array}{l}1 \\
1 \\
1 \\
1 \\
1\end{array}$ & $-\ldots \ldots$ & $\begin{array}{l}1 \\
1 \\
1 \\
1 \\
1\end{array}$ & $\begin{array}{l}1895 \\
1896 \\
1897 \\
189 . \\
1899\end{array}$ & $\begin{array}{l}398 \\
412 \\
420 \\
440 \\
444\end{array}$ & $\begin{array}{l}70 \\
77 \\
81 \\
94 \\
97\end{array}$ & $\begin{array}{l}468 \\
489 \\
501 \\
534 \\
541\end{array}$ & & $\begin{array}{l}1,131 \\
1,136 \\
1,141 \\
1,147 \\
1,156\end{array}$ & $\begin{array}{l}745 \\
757 \\
768 \\
783 \\
795\end{array}$ & $\begin{array}{l}1,876 \\
1,893 \\
1,909 \\
1,930 \\
1,951\end{array}$ \\
\hline 0. & $\begin{array}{l}2 \\
2 \\
2 \\
2 \\
2\end{array}$ & $\begin{array}{l}1 \\
1 \\
1 \\
1 \\
2\end{array}$ & $\begin{array}{l}\mathbf{3} \\
\mathbf{3} \\
\mathbf{3} \\
\mathbf{3} \\
\mathbf{4}\end{array}$ & $\begin{array}{l}1900 \\
1901 \\
1902 \\
1903 \\
1904\end{array}$ & $\begin{array}{l}717 \\
725 \\
743 \\
759 \\
767\end{array}$ & $\begin{array}{l}243 \\
253 \\
256 \\
269 \\
277\end{array}$ & $\begin{array}{r}960 \\
978 \\
999 \\
1,028 \\
1,044\end{array}$ & $\begin{array}{l}1932- \\
1933- \\
1934 .\end{array}$ & $\begin{array}{l}1,176 \\
1,214 \\
1,232 \\
1,250 \\
1,338\end{array}$ & $\begin{array}{l}823 \\
844 \\
853 \\
864 \\
896\end{array}$ & $\begin{array}{l}1,999 \\
2,058 \\
2,085 \\
2,114 \\
2,234\end{array}$ \\
\hline $375 \ldots$ & $\begin{array}{l}3 \\
3 \\
3 \\
4 \\
4\end{array}$ & $\begin{array}{l}\mathbf{3} \\
\mathbf{3} \\
\mathbf{3} \\
\mathbf{3} \\
\mathbf{3}\end{array}$ & $\begin{array}{l}6 \\
6 \\
6 \\
7 \\
7\end{array}$ & $\begin{array}{l}1905 . \\
1906 . \\
1907 . \\
1908 \\
1909 .\end{array}$ & $\begin{array}{l}820 \\
838 \\
852 \\
864 \\
867\end{array}$ & $\begin{array}{l}310 \\
336 \\
347 \\
366 \\
374\end{array}$ & $\begin{array}{l}1,130 \\
1,174 \\
1,199 \\
1,230 \\
1,241\end{array}$ & & $\begin{array}{l}1,360 \\
1,362 \\
1,364 \\
1,370 \\
1,380\end{array}$ & $\begin{array}{l}912 \\
921 \\
926 \\
938 \\
947\end{array}$ & $\begin{array}{l}2,272 \\
2,283 \\
2,290 \\
2,308 \\
2,327\end{array}$ \\
\hline 80. & $\begin{array}{r}9 \\
12 \\
17 \\
20 \\
22\end{array}$ & $\begin{array}{l}5 \\
6 \\
6 \\
6 \\
6\end{array}$ & $\begin{array}{l}14 \\
18 \\
23 \\
26 \\
28\end{array}$ & $\begin{array}{l}1910 . \\
1911 . \\
1912 . \\
1913 . \\
1914 .\end{array}$ & $\begin{array}{l}956 \\
964 \\
977 \\
984 \\
989\end{array}$ & $\begin{array}{l}423 \\
451 \\
471 \\
481 \\
502\end{array}$ & $\begin{array}{l}1,379 \\
1,415 \\
1,448 \\
1,465 \\
1,491\end{array}$ & $\begin{array}{l}1940 .- \\
1941 . \\
1942 . \\
1943 . \\
1944 .\end{array}$ & $\begin{array}{l}1,390 \\
1,396 \\
1,406 \\
1,411 \\
1,431\end{array}$ & $\begin{array}{r}957 \\
967 \\
977 \\
1,014 \\
1,051\end{array}$ & $\begin{array}{l}2,347 \\
2,363 \\
2,383 \\
2,425 \\
2,482\end{array}$ \\
\hline 35.. & $\begin{array}{r}61 \\
68 \\
72 \\
82 \\
190\end{array}$ & $\begin{array}{r}8 \\
12 \\
14 \\
17 \\
22\end{array}$ & $\begin{array}{r}69 \\
80 \\
86 \\
99 \\
212\end{array}$ & $\begin{array}{l}1915 . \\
1916 . \\
1917 . \\
1918 . \\
1919 .\end{array}$ & $\begin{array}{l}1,014 \\
1,023 \\
1,038 \\
1,048 \\
1,056\end{array}$ & $\begin{array}{l}540 \\
564 \\
576 \\
603 \\
615\end{array}$ & $\begin{array}{l}1,654 \\
1,587 \\
1,614 \\
1,651 \\
1,671\end{array}$ & $\begin{array}{l}1945 \\
1946 \\
1947 .\end{array}$ & $\begin{array}{l}1,458 \\
1,493 \\
1,499\end{array}$ & $\begin{array}{l}1,071 \\
1,100 \\
1,107\end{array}$ & $\begin{array}{l}2,529 \\
2,593 \\
2,606\end{array}$ \\
\hline
\end{tabular}

RESERVOIR CONTROL

UTAB IAKE

Utah Lake is the sole source of water for the Jordan Riv rr, and the use of that river for irrigation brought up as early as 1867 the question of storing water in the lake. The first dam in Jordan River for the purpose of holding back the water of the lake was constructed by Salt Lake County in 1872 and was destroyed the following year after riparian owners in Utah County complained that high water was damaging their lands. After several years of argument between the users of Jordan River water and the owners of land bordering the lake, an arbitration committee, appointed in 1884, proposed a compromise agreement which was adopted and is still in force. This agreement provided that the water of Utah Lake might be held at a height "not to exceed 3 feet and $3 \frac{1}{2}$ inches above the point established and recognized as low-water mark [the level at which natural outflow ceases]." 2 A monument was then erected to mark the level at which water might be held without liability for damage, and the compromise level was defined by subsequent court decision (Salt Lake City v. Colladge 13 Utah, p. 522 (1896), ) as "4 feet, 6 inches below the top of the stone monument at the outlet of the lake, which was established by the Utah Lake

\footnotetext{
2 The lake may rise above the compromise level if inflow after reaching that level exceeds the rate of natural outflow. Since 1900 the lake level has risen above the compromise level in 14 of 47 years, reaching its maximum stage, 3.3 feet above the compromise level, in 1922.
}

commission in 1885." In 1899 a stone obelisk (the "Lake Monument") was set about $20 \mathrm{ft}$ southeast of this original monument, with a copper bolt set near its base and inscribed " 5.985 feet above compromise."

Precise leveling to this bench mark shows that the monument has settled 0.41 foot in the past 25 years, as shown in the following tabulation. In 1946 the Utah State Engineer determined by leveling from undisturbed bench marks that the altitude of "compromise point" was 4,489.398 feet above sea level. The bench mark on the Lake Monument was therefore only 5.57 feet above the compromise point in 1946 .

\begin{tabular}{|c|c|c|c|}
\hline Year & Agency & Field engineer & $\begin{array}{l}\text { Altitude (feet } \\
\text { above sea level) } \\
\text { (1929 Gen. Adj.) }\end{array}$ \\
\hline $\begin{array}{l}1922 \\
1934 \\
1946\end{array}$ & $\begin{array}{l}\text { U.S. G. S } \\
\text { U. S. C. \& G.S. } \\
\text { Utah State Engineer. }\end{array}$ & $\begin{array}{l}\text { E. E. Harris } \\
\text { A. J. Oliver_... } \\
\text { R. J. Madsen_... }\end{array}$ & $\begin{array}{l}4,495.179 \\
4,494.856 \\
4,494.769\end{array}$ \\
\hline
\end{tabular}

Utah Lake has an area of about 96,000 acres (150 square miles) at compromise level. In the period 1900 to 1948 its surface area has ranged from about 115,000 acres in 1922 to 23,000 acres in 1935. At the level where natural outflow to the Jordan River ceases, the lake area is about 85,000 acres. The lake bed at its lowest surveyed point is about 14 feet below compromise level, and 45,000 acres of the bed lies more than 10 feet below the compromise level.

Capacity tables were prepared by the U. S. Bureau of Reclamation in February 1935, based upon a datum in which the compromise altitude is $4,488.95$ feet. According to these tables the capacity of the lake when the surface is at compromise level is about 850,000 acre-feet. Prior to 1902 the dead storage in the lake was about 550,000 acre-feet, but since that year pumps installed at the North Point of the lake have been able to lower the lake to a level about 9 feet below compromise level, and the dead storage in the lake is then about 140,000 acre-feet. Pumps installed in 1934 at Pelican Point near the deepest part of the lake are capable of drawing the lake down to a level 12 feet below compromise, leaving less than 23,000 acre-feet of water in dead storage.

Since 1925 the total diversions from Utah Lake, by gravity and pumping, have ranged from 71,600 acrefeet in 1935 to 337,000 acre-feet in 1928 , according to the annual reports of the Utah Lake and Jordan River Water Commissioner. In comparison it was estimated by Teele $(1903$, p. 80$)$ that diversions from the Jordan River in 1900, before pumps were installed on Utah Lake, amounted to 47,500 acre-feet. The highest lake level in that year was more than a foot higher than the maximum stage in 1928 , when 288,000 acre- 
feet was diverted from the river and lake by gravity and pumps (see pp. 69-71).

\section{DEER CREEK RESERVOIR}

The Deer Creek dam, completed by the U. S. Bureau of Reclamation in October 1941, is on the Provo River about 16 miles northeast of the city of Provo. It is an earth-fill dam with concrete cut-off wall, rising 155 feet above the stream bed and 235 feet above its rock foundation, and has a crest length of 1,300 feet between canyon walls. The reservoir created by this dam extends upstream for $6 \frac{1}{2}$ miles. It has a capacity of 152,560 acre-feet between altitudes 5,280 feet (bottom of outlet tunnel) and 5,417 feet (top of 20-foot radial gates), of which 2,870 acre-feet (below sill of trashrack structure at altitude 5,305 feet) is dead storage. Storage began in December 1940, and the reservoir was first filled to capacity in the period June 28 to July 3, 1947.

The operation of the reservoir is based on an active yield of 100,000 acre-feet annually, leaving 50,000 acrefeet of carry-over storage for dry years. The principal subscribers to the project and the proportionate share of the active annual storage allocated to each is as follows:

Metropolitan Water District of Salt Lake (Salt Lake

County) _. . . .

Utah Lake Distributing Co. (for irrigation in Salt Lake

County) _....... 15. 2

Metropolitan water districts of five municipalities in

Utah County ......... 10.0

Provo Reservoir Water Users Co. (for irrigation chiefly

in Utah County) ......... 16.0

Highland Conservation District (for irrigation in Utah County) . . . . 0

Provo Bench Canal \& Irrigation Co. (for irrigation in Utah County) ........... 2.0

Pleasant Grove Irrigation Co. (for irrigation in Utah County) . . . . . . . 1.0

Miscellaneous subscribers for less than 1 percent each (for irrigation in Wasatch and Utah Counties) ....... 2. 5

Total

Generally the flow of the Provo River continues through Deer Creek reservoir to satisfy water rights downstream and in Utah Lake, but when Utah Lake is at high stage, during peak discharge from melting snow, some surplus water in that river may be available for storage. However, the principal source of supply to the reservoir is the Weber River, which has in an average year enough surplus above present requirements to supply about 65,000 acre-feet, or two-thirds of the annual active yield of the reservoir. The WeberProvo diversion canal, which was enlarged to a capacity of $1,000 \mathrm{cfs}$ in 1946, is 9 miles long and conveys the surplus and winter power water from tributaries of the
Weber River into the Provo River and thence into Deer Creek reservoir. It is planned that ultimately the water supply to the reservoir will be further augmented by diversion of surplus runoff from the North Fork of the Duchesne River, in the Colorado River drainage basin.

\section{OTHER RESERVOIRS}

The largest reservoir in the northern part of Utah Lake valley is that owned by the Geneva Steel Co. This reservoir, located in secs. 7 and 8, T. 6 S., R. 2 E., has a surface area of 312 acres and a capacity of 2,274 acre-feet. It was constructed on the valley plain by excavation of the bottom to form banks as high as 12 feet on the north, west, and south sides. Water from several sources is collected in this reservoir and then is pumped and utilized in various operations and returned by gravity. Some water bypasses the reservoir after use and empties into Utah Lake. The utilization of water by the Geneva Steel Co. is more fully described on pages 91-92. It is to be noted that the reservoir is essentially an oversized tank for industrial operations and does not store flood waters for later use.

There are several small lakes and reservoirs in the headwaters of the tributaries to the northern part of Utah Valley, some of which are used to regulate the flow of the streams. The largest of these are six glacial lakes on the upper Provo River having a combined capacity of about 11,000 aere-feet, from which water can be released as needed for irrigation.

\section{FLUCTUATIONS IN WATER SUPPLY} STREAMS

Except for the Provo River, all the perennial streams entering the northern part of Utah Valley from the east have their headwaters west of the crest of the Wasatch Range and drain the steep west slope of that range. These streams, in order from north to south, are Dry Creek (formed by the junction of Fort Canyon and Alpine Creeks), American Fork River, Battle Creek, and Grove Creek; and south of the Provo River, Rock Creek and Slate Creek. The drainage basins above the mouths of the canyons range in area from 60 square miles for Amercian Fork River to 5 square miles for Battle Creek.

The Provo River heads in the high Grandaddy Lake region of the markedly glaciated Uinta Range. The drainage basin above the mouth of its canyon through the Wasatch Range has an area of about 650 square miles, of which only about 25 square miles is west of the crest of the Wasatch Range. The Provo River drainage basin east of the Wasatch Range is more than five times as large as the area of the west slope of 
that range tributary to northern Utah Valley; and it ordinarily furnishes twice the quantity of water yielded by the tributaries draining the west slope.

RECORDS OF STREAM DISCHARGE

Table 19 lists the available records of the discharge of streams tributary to the northern part of Utah Lake valley.

TABLE 19.-Stream-discharge records for northern Utah Valley

\begin{tabular}{|c|c|c|c|}
\hline Gaging station & $\begin{array}{l}\text { Drain- } \\
\text { age } \\
\text { basin } \\
\text { (sq. } \\
\text { mi.) }\end{array}$ & Period of record & Reference \\
\hline $\begin{array}{l}\text { Dry Creek: } \\
\text { Alpine Creek near Alpine... }\end{array}$ & 15 & Apr. 1938-Dec. 1940_.. & State Engi- \\
\hline $\begin{array}{l}\text { Fort Canyon Creek at Al- } \\
\text { pine. }\end{array}$ & 6 & Mar. 1938-Dec. 1940_. & \\
\hline $\begin{array}{l}\text { American Fork: } \\
\text { North Fork near American } \\
\text { Fork. } \\
\text { South Fork near American }\end{array}$ & $\begin{array}{r}39 \\
8\end{array}$ & $\begin{array}{l}\text { Apr. 1903-Dec. 1905-. } \\
\text { Feb. 1912-Sept. 1915_.. } \\
\end{array}$ & $\begin{array}{r}\text { USGS. } \\
\text { Do. } \\
\text { Do. }\end{array}$ \\
\hline $\begin{array}{l}\text { Fork } \\
\text { American Fork above up- } \\
\text { per power plant. }\end{array}$ & 50 & $\begin{array}{l}\text { Jan. 1918-Dec. 1919... } \\
\text { Jan. 1927 }\end{array}$ & Utah Power \& \\
\hline $\begin{array}{l}\text { American Fork at lower } \\
\text { power plant. }\end{array}$ & 60 & $\begin{array}{l}\text { May 1900-Dec. 1905. } \\
\text { Apr. 1938-Mar. 1941... }\end{array}$ & $\begin{array}{l}\text { USGS. } \\
\text { Utah State Engi- } \\
\text { neer. }{ }^{\circ}\end{array}$ \\
\hline $\begin{array}{l}\text { Battle Creek: } \\
\text { Battle Creek near Pleasant } \\
\text { Grove. }\end{array}$ & 5 & $\begin{array}{l}\text { Apr.-Sept. } 1940 \ldots \\
\text { May-Sept. 1941... }\end{array}$ & $\begin{array}{l}\text { Pleasant Grove Irr. } \\
\text { Co. } \\
\text { Do.3 }\end{array}$ \\
\hline $\begin{array}{l}\text { Provo River: } \\
\text { Provo River at Vivian } \\
\text { Park (above South Fork). }\end{array}$ & 595 & Oct. 1911- & USGS.2 \\
\hline $\begin{array}{l}\text { South Fork at Vivian Park } \\
\text { Provo River above Tellu- } \\
\text { ride dam. }\end{array}$ & $\begin{array}{r}34 \\
630\end{array}$ & $\begin{array}{l}\text { Nov. 1911- } \\
\text { Feb. 1905-Dec. 1911. }\end{array}$ & $\begin{array}{l}\text { Do. }{ }^{2} \\
\text { Do. }\end{array}$ \\
\hline $\begin{array}{l}\text { Provo River at canyon } \\
\text { mouth. }\end{array}$ & 650 & July 1889-June 1906..- & Do. ${ }^{3}$ \\
\hline $\begin{array}{l}\text { Provo River at U. P. R. R. } \\
\text { bridge. }\end{array}$ & 670 & May 1903-Dec. 1904_. & Do. ${ }^{2}$ \\
\hline Provo & 675 & $\begin{array}{l}\text { June 1933-Sept. 1934_... } \\
\text { Nov. 1938-........... }\end{array}$ & $\begin{array}{l}\text { Do. }{ }^{2} \\
\text { Do. }\end{array}$ \\
\hline
\end{tabular}

1 Unpublished records filed at State Capitol and at U. S. Geological Survey offices in Salt Lake City, Utah.

2 Published in annual Water-Supply Papers: Surface water supply of United States, Part 10, Great Basin.

Inpublished records filed in Salt Lake City office of U. S. Geological Survey.

The long-term records for the Provo River and American Fork River show characteristics of flow that aid in estimating the annual flow of other ungaged streams entering northern Utah Valley. Hydrographs showing the monthly discharge of American Fork River and of the South Fork of the Provo River are assembled in figure 16, together with a graph showing the increase of flow in the Provo River between Vivian Park and the mouth of the canyon.

The discharge of the South Fork of the Provo River commonly reaches two peaks each year, the first in May or June because of runoff from melting snow, and the second in October or November. A large proportion of the drainage basin of this stream is underlain by cavernous limestones and by far the larger part of the annual stream flow is derived from springs in these limestones. In figure 16 the part of the discharge that is attributed chiefly to the spring freshet is shaded; practically all the rest is of ground-water origin, and this ground-water discharge reaches a maximum in $247743-53-6$
October or November, 6 months later than the melting of accumulated winter snow and perhaps more than a year later than the precipitation that was the ultimate source of the ground water. It is evident from the graph that in dry years, such as 1931, 1934, and 1940, practically all the stream flow is from ground-water sources, and in all years ground water is the source of most of the stream flow. Even during the months of the spring freshet at least half the flow in the South Fork of Provo River is derived from ground water. In northern Utah Valley, Battle Creek is the only other stream known to be primarily dependent upon ground water for the bulk of its flow.

The hydrograph of American Fork River is typical of the majority of streams draining the Wasatch Range, as well as of most other mountain streams in the intermontane areas of the West. In contrast to the South Fork of the Provo River, most of its annual runoff occurs during a freshet in May and June, and the discharge thereafter decreases until the following spring. Only in the driest year, 1934, is there an obvious indication of a secondary peak discharge in October, such as is characteristic of the South Fork of the Provo. In several other dry years, however, notably 1931, 1939, and 1946, there is a slight increase in discharge in the fall, attributed to a seasonal increase in ground-water discharge from the limestones that crop out in the drainage basin. This hydrograph is considered to be representative of the seasonal and annual distribution of runoff in Dry Creek, Rock Creek, and Slate Creek because the geology, topography, and climatology of the several basins are comparable.

The third graph of figure 16 shows the differences between the combined monthly discharge of the Provo River and South Fork at Vivian Park, and the sum of diversions at the mouth of the canyon, measured over weirs by the Provo River Water Commissioner for the period April 1 to September 30 each year. The resulting graph, representing the runoff of the intervening drainage area of about 22 square miles plus the arithmetic difference between the subsurface flow at Vivian Park and at the mouth of the canyon, is subject to a large percentage of error, because a nominal error of say, 3 percent in gaging the total flow might cause an error of 20 to 30 percent in the increase in flow as obtained by subtraction. Nevertheless, the resulting hydrograph for the spring and summer (including the period of the annual freshet) agrees closely with the hydrograph for American Fork River, which has a drainage basin with characteristics similar to the canyon section of the Provo River. On the strength of this agreement, the gaps in the record during each winter have been sketched in with dotted lines, using the American Fork hydrograph as the basis. In some years, 
notably 1945 and 1946, the derived runoff from the canyon section is markedly less in midyear than might be expected; this may result from channel storage in the canyon during the freshet, or excessive evapotranspiration losses, or merely the large percentage of error that may occur in the computation of runoff by differences. stream flow in South Fork of the Provo River; the flow of Grove Creek is based upon a few miscellaneous discharge measurements, and statements of residents that it is a "smaller" stream than Battle Creek; the flow of Dry Creek is based on records for Alpine Creek and Fort Canyon Creek for 1938-40, and the assumption that in other years likewise the runoff is about the

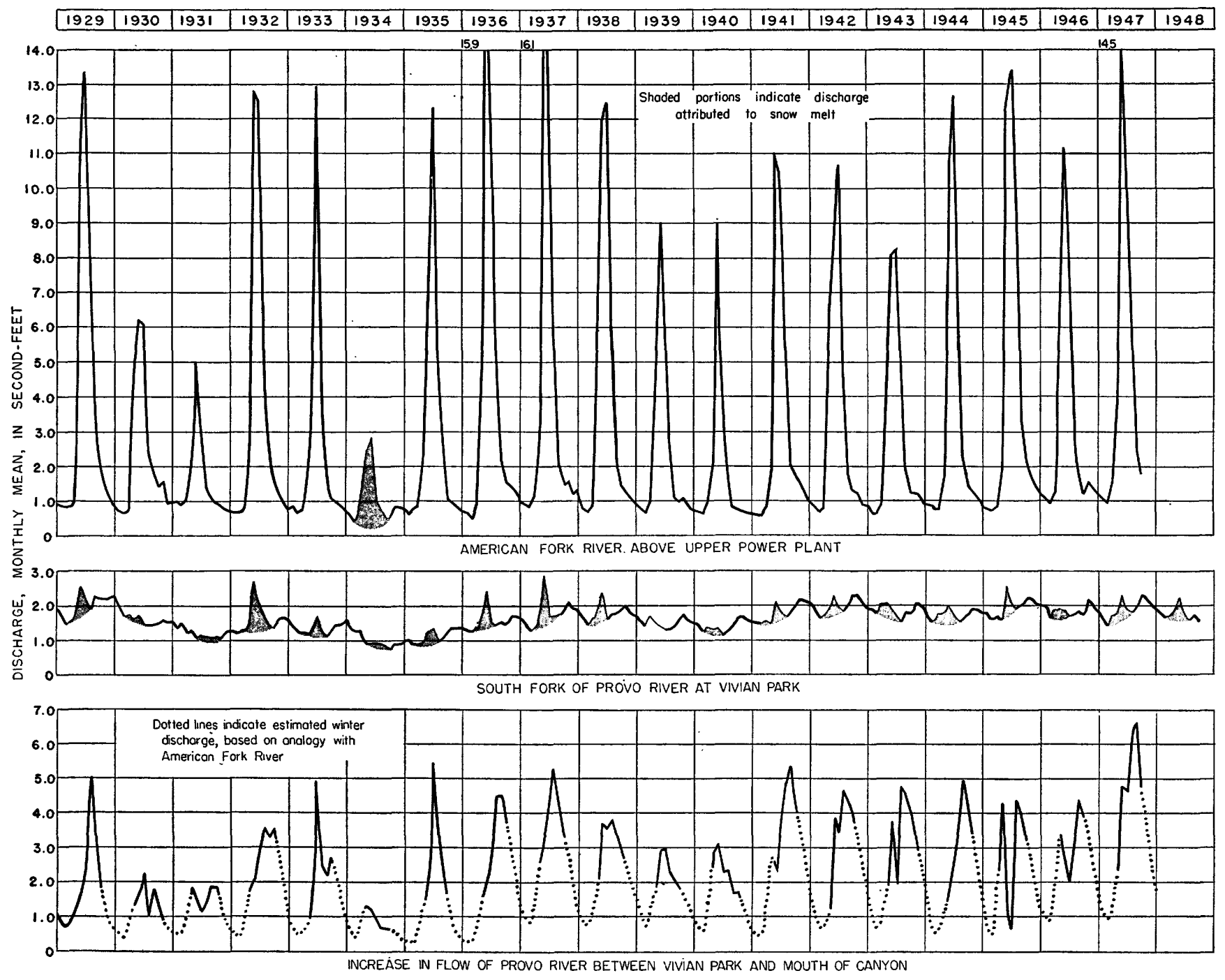

FiadRE 16.-Hydrographs showing discharge of American Fork River and South Fork Provo River, and increase in flow of Provo River below Vivian Park.

ESTIMATES OF SURFACE INFLOW TO NORTHERN UTAH VALLEY

The available records of stream discharge are used to derive rough estimates of the total annual surface inflow to northern Utah Valley. Estimates have been made for each perennial stream for years since 1931, as follows: the discharge of American Fork River and of Provo River at the mouths of the canyons is computed by correlating measured discharge over short periods with the long-term records of upstream gaging stations; the flow of Battle Creek is obtained from fragmentary records in 1945 and 1946, and from analogy with the same per square mile as in the larger drainage basin of American Fork River; discharges of Rock Creek and Slate Creek have not been measured, and it has been assumed that in those basins the runoff per square mile is equivalent to that of American Fork River.

The estimates in table 20 are based on measured discharge which comprises in all years at least two-thirds and in some years more than nine-tenths of the total.

Since 1931 the combined flow of the streams draining the west slope of the Wasatch Range, including tributaries of the Provo below Vivian Park, has averaged 
TABLE 20.-Estimated surface inflow to northern Utah Valley, in thousands of acre-feet

\begin{tabular}{|c|c|c|c|c|c|c|c|c|c|c|}
\hline \multirow{2}{*}{ Year } & \multirow{2}{*}{$\underset{\text { Creek }}{\text { Dry }}$} & \multirow{2}{*}{$\begin{array}{l}\text { Amer } \\
\text { ican } \\
\text { Fork }\end{array}$} & \multirow{2}{*}{$\begin{array}{l}\text { Battle } \\
\text { Creek }\end{array}$} & \multirow{2}{*}{$\begin{array}{l}\text { Grove } \\
\text { Oreek }\end{array}$} & \multirow{2}{*}{$\begin{array}{l}\begin{array}{l}\text { Provo } \\
\text { River }\end{array}\end{array}$} & \multirow{2}{*}{$\begin{array}{l}\text { Rock } \\
\text { Creek }\end{array}$} & \multirow{2}{*}{\begin{tabular}{|l|} 
Slate \\
Creek
\end{tabular}} & \multirow{2}{*}{ Total } & \multicolumn{2}{|c|}{$\begin{array}{l}\text { Diversions } \\
\text { from other } \\
\text { basins }\end{array}$} \\
\hline & & & & & & & & & $\begin{array}{l}\text { Weber } \\
\text { River }\end{array}$ & $\begin{array}{l}\text { Parleys } \\
\text { Creek }\end{array}$ \\
\hline $\begin{array}{l}1931 \ldots \\
1932 \ldots \\
1933 \ldots \\
1934 \ldots \\
1935 \ldots \\
1936 \ldots \\
1937 \ldots \\
1938 \ldots \\
1939 \ldots \\
1940 \\
1941 \\
1942 \ldots \\
1943 \ldots \\
1944 \ldots \\
1945 \ldots \\
1946 \ldots\end{array}$ & $\begin{array}{r}12 \\
24 \\
19 \\
8 \\
21 \\
27 \\
126 \\
125 \\
120 \\
128 \\
23 \\
23 \\
21 \\
23 \\
28 \\
24\end{array}$ & $\begin{array}{r}23 \\
55 \\
40 \\
17 \\
44 \\
62 \\
60 \\
157 \\
138 \\
131 \\
50 \\
50 \\
45 \\
51 \\
62 \\
50\end{array}$ & $\begin{array}{r}2 \\
3 \\
2 \\
2 \\
2 \\
3 \\
4 \\
4 \\
3 \\
3 \\
4 \\
4 \\
3 \\
3 \\
14 \\
13\end{array}$ & $\begin{array}{l}1 \\
3 \\
2 \\
1 \\
3 \\
4 \\
3 \\
3 \\
2 \\
2 \\
2 \\
3 \\
3 \\
2 \\
3 \\
3 \\
3 \\
3\end{array}$ & $\begin{array}{r}148 \\
294 \\
229 \\
115 \\
220 \\
323 \\
315 \\
1319 \\
1319 \\
1228 \\
1193 \\
1267 \\
1284 \\
1327 \\
1308 \\
1332 \\
1314 \\
1314\end{array}$ & $\begin{array}{r}5 \\
11 \\
8 \\
3 \\
9 \\
12 \\
12 \\
11 \\
86 \\
66 \\
10 \\
10 \\
9 \\
10 \\
12 \\
10\end{array}$ & $\begin{array}{l}2 \\
5 \\
4 \\
2 \\
4 \\
6 \\
6 \\
6 \\
4 \\
3 \\
5 \\
5 \\
4\end{array}$ & $\begin{array}{l}193 \\
395 \\
304 \\
148 \\
303 \\
437 \\
446 \\
425 \\
303 \\
246 \\
362 \\
379 \\
411 \\
403 \\
447 \\
409\end{array}$ & $\begin{array}{r}3 \\
17 \\
111 \\
13 \\
111 \\
117 \\
112 \\
166 \\
112 \\
14 \\
19 \\
117 \\
135 \\
158 \\
140 \\
163\end{array}$ & \\
\hline
\end{tabular}

1 Measured; all other quantities estimated, or extrapolated from records obtained at stations upstream from mouths of canyons.

about half as much as the flow of the Provo River from its drainage basin east of the range, or about onethird of the total surface inflow to northern Utah Valley. The total drainage area on the west slope of the Wasatch Range is about 110 square miles, less than one-fifth of the area of the drainage basin of the Provo River above Vivian Park, and it is evident that this west slope of the range has a higher yield of water per square mile than the Provo drainage basin to the east.

The computations also indicate that since 1931 the Provo River at the mouth of its canyon has discharged about 75 percent of the total surface inflow into northern Utah Valley, and that its discharge has ranged from 72 percent of the total flow in 1935 to 80 percent in 1943. Estimates of the total surface inflow prior to 1931 are based upon application of this same ratio to measurements (in 1890-1908) or computations (for 1909-30) of the discharge at the mouth of Provo Canyon. According to these estimates the total annual surface inflow to northern Utah Valley has ranged from about 148,000 acre-feet in 1934 to 735,000 acre-feet in 1909. The average annual inflow in 55 years of record has been 440,000 acre-feet. Between 1930 and 1947 this rate was exceeded only in 1945 , when the runoff was about 447,000 acre-feet, but in six other years the estimated runoff was close to the long-term average. Since 1942 diversions from the Weber River drainage basin have contributed 35,000 to 63,000 acre-feet annually to the flow of the Provo River as compared with a maximum of 17,000 acre-feet in earlier years.

\section{RESFRVOIRS UTAH LAKE}

Utah Lake receives all the water that passes from the bordering lowland areas of Utah Valley. From northern Utah Valley it receives the water discharged directly into the lake by streams, seepage and return waters from irrigated lands, storm runoff from heavy precipitation over the valley area, sewage and industrial wastes, and water that moves underground and is then discharged into the lake either along its margins or through the sediments of the lake bottom. The lake also receives similar discharge from the southern part of Utah Valley, which has not been included in the study upon which this report is based.

EMPIRICAL DETERMINATIONS OF NATURAL LOSS AND INFLOW

The Utah Lake and Jordan River Water Commissioner, in his annual report (Gardner, reports 1936-47), to the State Engineer, includes tables showing monthly inflow and outflow of Utah Lake, computed evaporation from the lake surface, and total diversion. A summary of these data by calendar years is presented in an accompanying table (table 21). The net change in storage is determined from the lake stages at the end of each year, using the capacity tables prepared by the Bureau of Reclamation in 1935. (See p. 65.) Evaporation is computed by multiplying the average surface area of the lake each month by 80 percent of the land-pan evaporation as recorded near the outlet of the lake. (See table 3.) The measured outflow includes the combined flow of the Jordan River, Utah and Salt Lake Canal, and East Jordan Canal, as measured at the U. S. Geological Survey gaging stations at the Narrows (Surface water reports, 191447), plus the diversions into the Utah Lake Distributing Co. Canal. The computed inflow is equal to the algebraic sum of the evaporation, measured outflow, and change in storage. The total diversion comprises all water taken from the lake or the Jordan River for use in Jordan Valley; since 1925 the diversions have exceeded the measured outflow from the lake because practically all outflow has been used, and in addition there is return flow to the river channel below the Narrows, which is diverted to users farther downstream.

The historic relations between precipitation, lake levels, computed inflow, and measured outflow of Utah Lake are shown graphically in figure 17. These graphs show that the maximum stage of the lake since records began in 1883 occurred in 1884, when a dam was constructed in Jordan River to store water in the lake for use in Jordan Valley. The installations of pumps at North Point in 1902 and at Pelican Point in 1934 are reflected in the greater annual range of lakelevel fluctuations subsequent to those years. There was natural outflow from the lake in all years prior to 1931 , but from 1931 to 1943 pumps were required for all the water that was used from the lake.

The changes in lake levels from year to year reflect the meteorologic conditions as shown by the cumulative deviation from normal precipitation at Heber. The 

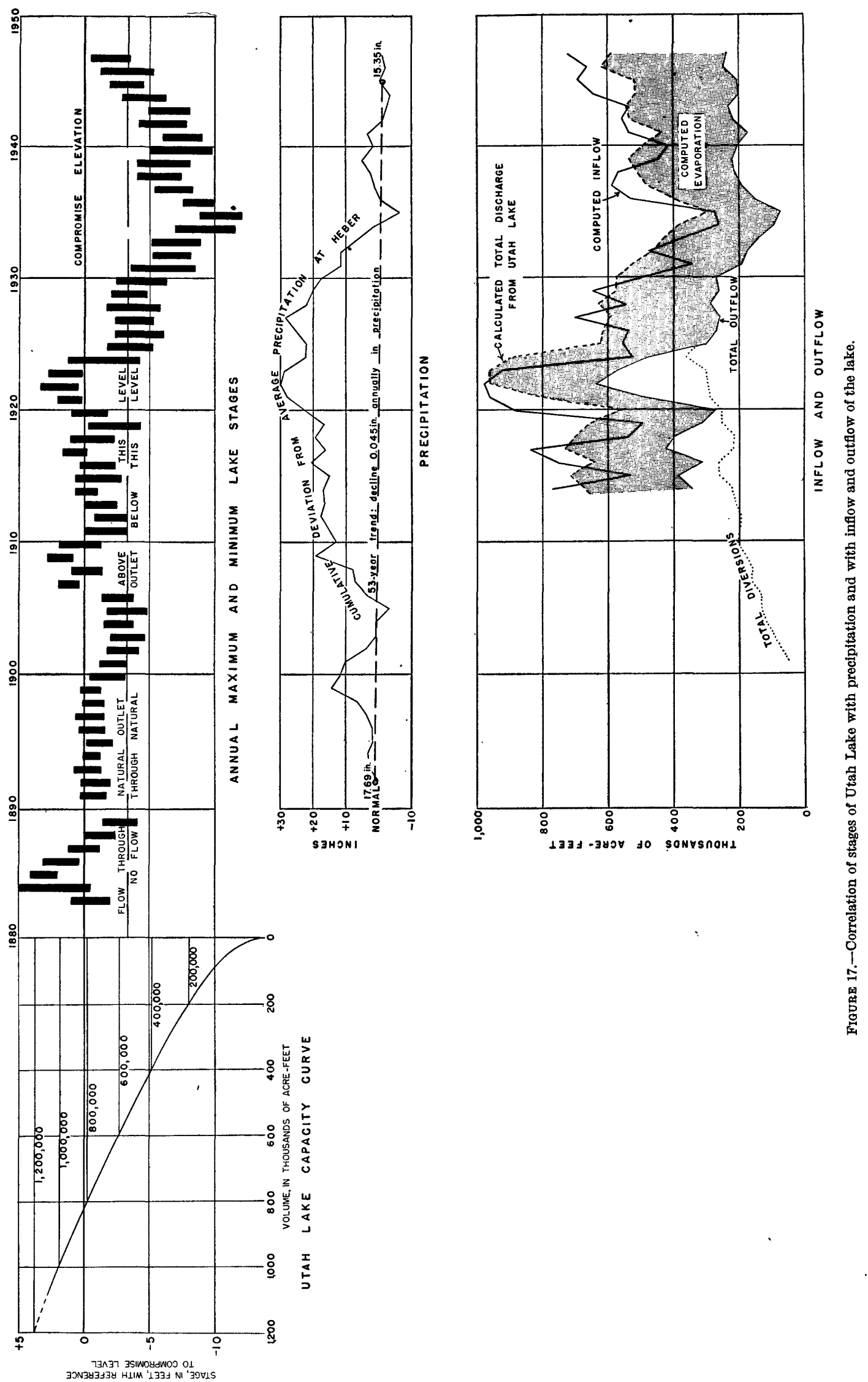
TABLE 21.-Annual changes in storage, inflow, and outflow of Utah Lake, in thousands of acre-feet

[From annual reports of the Utah Lake and Jordan River Water Commissioner]

\begin{tabular}{|c|c|c|c|c|c|}
\hline Calendar year & $\begin{array}{c}1 \\
\text { Net change } \\
\text { in storage }\end{array}$ & $\begin{array}{c}2 \\
\text { Computed } \\
\text { evapora- } \\
\text { tion }\end{array}$ & $\begin{array}{c}3 \\
\text { Total out- } \\
\text { flow }\end{array}$ & $\begin{array}{c}4 \\
\text { Computed } \\
\text { inflow } 1\end{array}$ & $\begin{array}{c}5 \\
\text { Total di- } \\
\text { version }\end{array}$ \\
\hline \multirow{4}{*}{$\begin{array}{l}1914 . \\
1915 .\end{array}$} & +97.6 & 328.7 & 342.8 & 769.1 & 219.1 \\
\hline & $\begin{array}{l}-196.8 \\
+107.6\end{array}$ & $\begin{array}{r}331.6 \\
327.9\end{array}$ & $\begin{array}{l}384.9 \\
312.4\end{array}$ & $\begin{array}{l}519.7 \\
747.9\end{array}$ & 263.4 \\
\hline & +110.9 & 304.7 & 424.4 & 840.0 & $\begin{array}{l}216.8 \\
213.3\end{array}$ \\
\hline & $\begin{array}{l}-100.0 \\
-157.8\end{array}$ & $\begin{array}{l}301.2 \\
338.9\end{array}$ & $\begin{array}{l}587.4 \\
311.3\end{array}$ & $\begin{array}{l}038.0 \\
492.4\end{array}$ & 249 \\
\hline \multirow[t]{3}{*}{1920.} & $\begin{array}{l}+328.1 \\
+156.1\end{array}$ & $\begin{array}{l}278.1 \\
314.8\end{array}$ & $\begin{array}{r}270.3 \\
489.9\end{array}$ & $\begin{array}{l}876.5 \\
960.8\end{array}$ & $\begin{array}{l}256.1 \\
290.2\end{array}$ \\
\hline & $\begin{array}{r}+17.5 \\
-460\end{array}$ & 325.1 & 635.6 & 978.2 & $\begin{array}{l}296.4 \\
300.8\end{array}$ \\
\hline & $\begin{array}{r}-44.0 \\
-373.9\end{array}$ & $\begin{array}{l}397.1 \\
420.6\end{array}$ & $\begin{array}{l}5690.0 \\
480.1\end{array}$ & $\begin{array}{l}920.1 \\
526.8\end{array}$ & $\begin{array}{l}300 . \\
365 . \\
\end{array}$ \\
\hline \multirow[t]{4}{*}{1925} & -66.9 & 329.4 & 292.1 & 554.6 & 314.5 \\
\hline & 6 & 349.8 & 266 & 536 & 285.4 \\
\hline & $\begin{array}{l}+111.3 \\
-87.2\end{array}$ & 330.1 & 259 & 700.5 & $\begin{array}{l}303.9 \\
337.4\end{array}$ \\
\hline & +70.2 & $\begin{array}{l}\text { Sis. } \\
313.7\end{array}$ & 260.9 & 644.8 & \\
\hline \multirow{4}{*}{1930} & & 304.5 & 268.6 & 495.5 & 310.3 \\
\hline & $\begin{array}{r}-180.7 \\
+8.5\end{array}$ & 333.6 & $\begin{array}{l}189.9 \\
176.3\end{array}$ & $\begin{array}{l}342.8 \\
472.4\end{array}$ & $\begin{array}{l}208.3 \\
188.0\end{array}$ \\
\hline & $\begin{array}{r}T 4.0 \\
-54.0\end{array}$ & 289.2 & $\begin{array}{l}140.3 \\
140.3\end{array}$ & $\begin{array}{l}71.4 \\
375.5\end{array}$ & $\begin{array}{l}100.0 \\
154.4\end{array}$ \\
\hline & -120.0 & & & 260.0 & 96.6 \\
\hline \multirow{4}{*}{1935.} & $\begin{array}{r}-16.9 \\
+122.3\end{array}$ & $\begin{array}{r}219.7 \\
255.6\end{array}$ & $\begin{array}{r}71.6 \\
150 ?\end{array}$ & $\begin{array}{l}274.4 \\
598,1\end{array}$ & $\begin{array}{r}78.1 \\
169\end{array}$ \\
\hline & $\begin{array}{r}+122.3 \\
+102.3\end{array}$ & $\begin{array}{l}203.0 \\
293.1\end{array}$ & $\begin{array}{l}150.2 \\
191.0\end{array}$ & $\begin{array}{l}588.1 \\
586.4\end{array}$ & $\begin{array}{l}109.5 \\
213.9\end{array}$ \\
\hline & $\begin{array}{r}+58.0 \\
\end{array}$ & 298.6 & 212.5 & 569.1 & 236.6 \\
\hline & & 314.9 & 220.3 & 446.5 & 252.6 \\
\hline \multirow{4}{*}{1940} & & & & $\begin{array}{l}414.1 \\
533.7\end{array}$ & $\begin{array}{l}232.2 \\
2054\end{array}$ \\
\hline & $\begin{array}{r}1 \\
+22.5 \\
\end{array}$ & $\begin{array}{l}200.5 \\
320.5\end{array}$ & $\begin{array}{l}172.0 \\
214.5\end{array}$ & 年 & $\begin{array}{l}250.9 \\
250.9\end{array}$ \\
\hline & & & & & 260 \\
\hline & & & & & \\
\hline 1945 & & 315 & & 69 & \\
\hline 1947 & $\begin{array}{r}+42.0 \\
+131.0\end{array}$ & $\begin{array}{l}378.8 \\
350.0\end{array}$ & $\begin{array}{l}239.0 \\
239.1\end{array}$ & $\begin{array}{l}660.9 \\
720.0\end{array}$ & 282.0 \\
\hline
\end{tabular}

1 Sum of columns 1,2 , and 3.

droughts of 1900-5 and 1928-35 (table 1) are indicated by downward trends in both graphs, and there is a similar parallelism during the periods of excessive precipitation, 1906-9 and 1920-22. The long-term downward trend in precipitation is reflected by the generally lower lake levels in recent years, but those lower levels can be ascribed in part to the increased proportion of the inflow that has been diverted for beneficial use.

The record of outflow shows that in series of years of excessive precipitation, the peak runoff has exceeded the capacities of existing canals, and surpluses of water have wasted into Great Salt Lake. This condition has not occurred in the 25-year period 1925-49, and may occur only rarely in the future, for the Deer Creek reservoir will be available for storage of surplus water in wet cycles.

A significant feature of these graphs is the large proportion of the computed inflow that is lost by evaporation from this broad but shallow lake. Computed evaporation losses have ranged from 220,000 acre-feet in 1935 when the computed inflow was 275,000 acre-feet, to 420,000 acre-feet in 1924 when inflow was 525,000 acre-feet. In comparison with the water put to beneficial use by man, as represented by the total diversions, the estimated loss by evaporation is appallingly high. In 1935 the evaporation loss was almost three times as great as the beneficial use, and in all years except 1930 the evaporation has exceeded the diversions. The evaporation is least when the area of water surface is least, and alternative proposals to obtain increased use of water supplies include reduction of water-surface area by diking off the shallow portions of the lake, and developing deeper or higher reservoirs elsewhere in the drainage basin, so that storage in Utah Lake may be held to a minimum.

\section{DEFICIENCIES IN BASIC DATA}

The data presented in the preceding section show that large quantities of water enter Utah Lake and are there wasted by evaporation, and also that the computed inflow and outflow of the lake are related to the meteorologic conditions. For purposes of quantitative determinations of water available for existing rights as well as for planning projects for making beneficial use of water now being lost by evaporation, these calculated data have an obvious weakness: only the measured outflow is supported by adequate basic data. The computations of evaporation, and hence of total inflow which is merely the sum of the measured outflow and the evaporation, are derived by use of empirical coefficients. Furthermore, the total inflow as computed by this method gives no indication of the proportions that are derived respectively from surface flow and subsurface flow.

Evaporation.-The computations of evaporation from Utah Lake are based on the assumption that the rate of evaporation is 80 percent of the evaporation measured at the standard Weather Bureau land pan at the north end of the lake. Although the evaporation from open-water surfaces is commonly accepted as more nearly 70 percent of the land-pan evaporation, the larger figure is justified by its proponents because of the shallowness of Utah Lake. For every percentile that the empirical constant differs from the true rate of evaporation, an error of 3,000 to 5,000 acre-feet in total inflow is introduced. It is evident, therefore, that detailed study is highly desirable to obtain as accurately as possible the true rate of evaporation.

Surface inflow.-The discharge into Utah Lake of its two largest tributaries has been measured at the gaging stations on the Provo River at Provo and on Spanish Fork near Lake Shore. In the years 1939 to 1946 the annual flow to the lake from these two streams has ranged from 29 to 39 percent of the computed inflow to the lake.

The most comprehensive survey of the surface inflow to Utah Lake in 1937 to 1940 is that made under the direction of S. T. Harding, consulting engineer to the Board of Canal Presidents of the Associated Canals. This board has kindly permitted study of these records during the present investigation of the water resources 
of northern Utah Valley. The records show that large quantities of water flow into Utah Lake from the surface of each of the major alluvial fans bordering the northeast part of the lake. The discharge in the natural channels of Dry Creek and American Fork River is a very small proportion of the total surface discharge from the fans of those streams. In dry years the discharge of the Provo River into the lake is less than that from other sources along the base of the fan between Provo Bay and Geneva. These "other" sources of surface flow include springs, flowing wells, drains, sewers, return flow or waste irrigation water, and local precipitation. A comparison between the estimated inflow to Utah Valley from tributary canyons and the surface discharge into Utah Lake is afforded by the accompanying table 22 .

TABLE 22.-Surface inflow to and discharge from, in thousands of acre-feet, principal alluvial fans of northern Utah Valley

\begin{tabular}{|c|c|c|c|c|}
\hline & 1837 & 1938 & 1939 & 1940 \\
\hline $\begin{array}{l}\text { Provo River alluvial fan: } \\
\text { Inflow: } \\
\text { Provo River }{ }^{1} \\
\text { Rock Creek }{ }^{1} \\
\text { Slate Creek } 1\end{array}$ & $\begin{array}{r}315 \\
12 \\
6\end{array}$ & $\begin{array}{r}319 \\
11 \\
6\end{array}$ & $\begin{array}{r}228 \\
8 \\
4\end{array}$ & $\begin{array}{r}193 \\
\mathbf{6} \\
3\end{array}$ \\
\hline Total & 333 & 336 & 240 & 202 \\
\hline $\begin{array}{l}\text { Outflow: } \\
\quad \text { Provo River }{ }^{2} \\
\text { Other }{ }^{2}\end{array}$ & $\begin{array}{r}144.0 \\
96.5 \\
\end{array}$ & $\begin{array}{l}142.5 \\
101.6 \\
\end{array}$ & $\begin{array}{l}83.1 \\
85.4\end{array}$ & $\begin{array}{l}68.2 \\
82.9\end{array}$ \\
\hline Total...... & 240.5 & 244.1 & 168.5 & 151.1 \\
\hline $\begin{array}{l}\text { American Fork alluvial fan: } \\
\text { Inflow: } \\
\text { American Fork } 1 \\
\text { Battle Creek } 1 \\
\text { Grove Creek } 1 \text {. }\end{array}$ & $\begin{array}{r}60 \\
4 \\
3 \\
\end{array}$ & $\begin{array}{r}57 \\
4 \\
3 \\
\end{array}$ & $\begin{array}{r}38 \\
3 \\
2\end{array}$ & $\begin{array}{r}31 \\
3 \\
2\end{array}$ \\
\hline Total & 67 & 64 & 43 & 36 \\
\hline $\begin{array}{l}\text { Outflow: } \\
\quad \text { American Fork }{ }^{2} \\
\text { Other }{ }^{2}\end{array}$ & $\begin{array}{r}2.2 \\
42.6 \\
\end{array}$ & $\begin{array}{r}2.5 \\
34.1 \\
\end{array}$ & $\begin{array}{r}.6 \\
33.5\end{array}$ & 25.9 \\
\hline Total.......... & 44.8 & 36.6 & 34.1 & 26.4 \\
\hline $\begin{array}{l}\text { Dry Creek alluvial fan: } \\
\text { Inflow: } \\
\text { Dry Creek } 1 . .\end{array}$ & 26 & 25 & 20 & 18 \\
\hline $\begin{array}{l}\text { Outflow: } \\
\text { Dry Creek }{ }^{2} \ldots \\
\text { other }{ }^{2}\end{array}$ & $\begin{array}{r}.4 \\
6.6 \\
\end{array}$ & $\begin{array}{r}.6 \\
17.7 \\
\end{array}$ & $\begin{array}{r}.2 \\
4.9\end{array}$ & $\begin{array}{l}\mathbf{0} \\
\mathbf{6} .\end{array}$ \\
\hline Total.... & 7.0 & 18.3 & 5.1 & 6.4 \\
\hline $\begin{array}{l}\text { Summary: } \\
\text { Inflow from canyons. } \\
\text { Outflow to lake. }\end{array}$ & $\begin{array}{l}426 \\
292\end{array}$ & $\begin{array}{l}425 \\
299\end{array}$ & $\begin{array}{l}303 \\
208\end{array}$ & $\begin{array}{l}246 \\
184\end{array}$ \\
\hline
\end{tabular}

1 From table 20 on page 69.

2 Watson, Gardner, and Harding, 1941, tables 5-8, showing contributions to Utah Lake.

The computed inflow to Utah Lake as shown in table 21, however, is far larger than the observed inflow as measured by Watson, Gardner, and Harding in their survey. And, in 1946, the computed inflow of 666,000 acre-feet was greater by about 130,000 acre-feet than the measured inflow to Utah Valley, as recorded at gaging stations on the Provo River and South Fork at Vivian Park, Spanish Fork at Castilla, American Fork River near American Fork, Hobble Creek near Springville, Alpine Creek and Fort Creek near Alpine,
Payson Creek near Payson, and Battle Creek near Pleasant Grove. If the computed inflow is even reasonably accurate, this difference of 130,000 acre-feet, plus all the water consumptively used by agricultural crops and non-beneficial vegetation throughout the valley, must have been derived from unmeasured surface and subsurface inflow in tributary canyons and from precipitation over the valley.

Subsurface inflow.-In the preceding section it has been shown that the computed inflow to Utah Lake is greater than the measured inflow to Utah Valley from seven streams, of which four are the largest tributaries of Utah Lake. It has also been shown that the surface inflow to the lake from the fans of three of these tributaries (Provo River, American Fork River, and Dry Creek) over a 4-year period was less than 75 percent of the water that flowed onto those fans from the tributary drainage basin. By far the greater part of the water that enters the valley from the tributary canyons seeps into the ground, either along the natural channels or in irrigation ditches or irrigated tracts. Some of this water is then used by plants. Much of it reappears at the surface in springs, seeps, wells, or drains at lower elevations and then flows to the lake, constituting a major fraction of the total surface inflow in the northern part of Utah Valley. An unmeasured portion does not reappear at the surface but seeps into the lake from the underlying sediments. This portion is the subsurface inflow.

Springs in the bottom of the lake constitute a source of water. A reconnaissance of the lake bed in 1935 when pumps had reduced the lake area to 23,000 acres, leaving three-fourths of the lake bed dry, resulted in location of several spring areas in the western part of the lake bed, but the flow from these areas was negligible at that time. Greater yield in subsequent years may be inferred because of greater storage in the groundwater reservoir, but it is doubtful that springs constitute a major source of inflow to the lake.

The likelihood of ground-water movement directly into the lake, both by underflow in the post-Provo alluvium and by seepage through the Lake Bonneville group from underlying artesian aquifers, is discussed subsequently (pp. 80, 89). Accurate determinations of the quantity of ground-water movement, however, will require detailed study of the hydraulic characteristics of each aquifer that yields water to the lake. Such a determination of the source and amount of subsurface inflow is essential for adequate planning for greater utilization of the water of Utah Lake. Thus diking off certain shallow parts of the lake will serve no practical purpose if those shallow parts receive subsurface inflow to the extent that there is no reduction in evaporation losses. 


\section{DEER CREEX RESERVOIR}

The Deer Creek reservoir, completed in October 1940, was first filled to capacity in June 1946. Holdover storage in 1947 and 1948 amounted to at least half the capacity of the reservoir. Records of daily storage are published annually in Water-Supply Papers of the U. S. Geological Survey. For the present study the most significant feature of the Deer Creek storage is that a large proportion is derived from other drainage basins and thus represents a water supply over and above that which would be available to the Jordan River basin under natural conditions. Strict accounting for all the water that enters or leaves the reservoir is essential, because the rights to reservoir storage are separate and distinct from those to the natural flow of the Provo River.

A question raised recently by the users of water from Deer Creek reservoir serves to demonstrate the importance of obtaining adequate basic data before the construction of major development projects. At the time the dam was constructed, the region was unmapped topographically, geologically, or hydrologically. Recent detailed geologic studies have shown that the dam and reservoir rest upon the shattered bottom of a huge overthrust block with an essentially horizontal fault plane. ${ }^{3}$ The problem posed by the water users concerns the amount of water loss along this fault plane. If there is such loss, it is charged as reservoir loss to the Deer Creek water users, and when it reenters the Provo River downstream it is not discriminated from the "natural" flow of that stream, to which other water users have long-established rights. It is now known that geologic conditions may permit water loss both to the canyon downstream from the

3 Baker, A. A., ర. s. Geol. Survey. Oil and Gas Inv. Map (in preparation). dam and to the canyon of South Fork, but available hydrologic data are inadequate to show the extent of loss. A close determination of the subsurface leakage may require draining of the reservoir, which might entail serious loss to the water users dependent upon the reservoir and its hold-over storage for a permanent firm water supply.

\section{DISCHARGE FROM WELLS}

The most comprehensive information concerning the discharge of wells in Utah Valley was obtained by the State Engineer in cooperation with the Works Projects Administration in the years 1938 to 1940 . Most of the wells were visited one or more times each year, and the discharge was measured by volumetric methods. An estimate was made of the number of days during the year that the well discharged, and the annual discharge in acre-feet was computed. The results, tabulated below, show that the total discharge from wells in the northern part of Utah Valley ranged from about 27,000 acre-feet in 1940 to 32,000 acre-feet in 1939 .

The vagaries of well operation in Utah Valley limit estimates of discharge to rough approximations. Some wells flow continuously, others in the irrigation season only, some for periods of several days at a time, and still others flow intermittently during daylight hours. The characteristics of artesian flow introduce another variable, for the discharge of most wells is greatest when the well is first opened and becomes less as the well continues to flow. Under these conditions an accurate inventory of ground-water discharge would require a meter on every well used. For a modestly financed investigation the methods employed in the State Engineer's survey offer as good an approximation as can be obtained. No data are available for years other than those tabulated. (See tables 23 and 24.)

TABLE 23.-Water, in acre-feet, yielded annually by wells in Highland district, 1938-40

[Based on measurements and estimates by Utah State Engineer]

\begin{tabular}{l|c|c|c|c|c|c|c|c|c|c|c|c|c|}
\hline \multirow{2}{*}{ Section } & \multicolumn{5}{|c|}{1938} & \multicolumn{3}{|c}{1939} & \multicolumn{3}{c}{1940} \\
\cline { 2 - 7 } & Irrigation & Other & Waste & Total & Irrigation & Other & Waste & Total & Irrigation & Other & Waste & Total \\
\hline
\end{tabular}

T. 4 S., R. 1 E.

\begin{tabular}{|c|c|c|c|c|c|c|c|c|c|c|c|c|}
\hline $\begin{array}{l}25 \\
32 \\
34 \\
35 \\
36\end{array}$ & i & $\begin{array}{r}1 \\
1 \\
1 \\
3 \\
11 \\
8\end{array}$ & 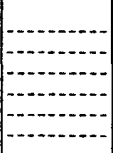 & $\begin{array}{r}1 \\
1 \\
1 \\
4 \\
11 \\
8\end{array}$ & 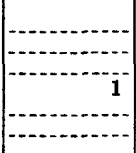 & $\begin{array}{l}2 \\
1 \\
1 \\
2 \\
8 \\
6\end{array}$ & 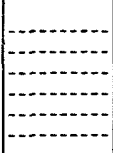 & $\begin{array}{l}2 \\
1 \\
1 \\
3 \\
8 \\
6\end{array}$ & 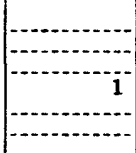 & $\begin{array}{l}2 \\
1 \\
1 \\
2 \\
8 \\
6\end{array}$ & 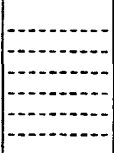 & $\begin{array}{l}2 \\
1 \\
1 \\
3 \\
8 \\
6\end{array}$ \\
\hline
\end{tabular}

T. 5 S., R. 1 W.

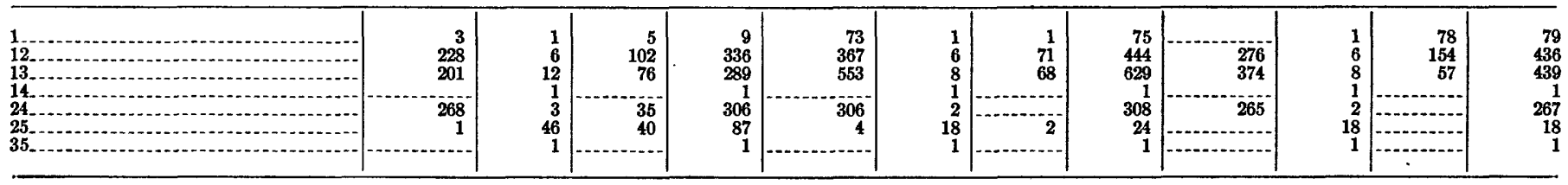


TABLE 23.-Water, in acre-feet, yielded annually by wells in Highland district, 1988-40-Continued [Based on measurements and estimates by Utah State Engineer]

\begin{tabular}{|c|c|c|c|c|c|c|c|c|c|c|c|c|}
\hline \multirow{2}{*}{ Section } & \multicolumn{4}{|c|}{1938} & \multicolumn{4}{|c|}{1939} & \multicolumn{4}{|c|}{1940} \\
\hline & Irrigation & Other & Waste & Total & Irrigation & Other & Waste & Total & Irrigation & Other & Waste & Total \\
\hline $\begin{array}{l}50 \\
910 \\
12 \\
13 \\
14\end{array}$ & \begin{tabular}{r}
59 \\
238 \\
14 \\
\hdashline 6 \\
\hdashline 67 \\
111 \\
755 \\
280 \\
370 \\
433 \\
648 \\
246 \\
595 \\
150 \\
146 \\
952 \\
486 \\
198 \\
11 \\
12 \\
98 \\
152
\end{tabular} & \begin{tabular}{r}
1 \\
6 \\
1 \\
5 \\
3 \\
2 \\
92 \\
11 \\
2 \\
2 \\
6 \\
18 \\
18 \\
126 \\
170 \\
19 \\
4 \\
17 \\
11 \\
\hdashline 38 \\
16 \\
9 \\
\hdashline 1 \\
11 \\
1 \\
1 \\
1 \\
2
\end{tabular} & \begin{tabular}{rr|} 
\\
\hdashline 54 \\
\hdashline 5 \\
\hdashline 54 \\
\hdashline 54 \\
112 \\
61 \\
59 \\
80 \\
33 \\
47 \\
28 \\
43 \\
53 \\
60 \\
125 \\
168 \\
5 \\
2 \\
80 \\
137
\end{tabular} & $\begin{array}{r}1 \\
6 \\
1 \\
5 \\
146 \\
240 \\
111 \\
11 \\
2 \\
8 \\
6 \\
90 \\
183 \\
993 \\
511 \\
448 \\
517 \\
698 \\
304 \\
623 \\
231 \\
215 \\
1,021 \\
611 \\
367 \\
17 \\
15 \\
179 \\
291\end{array}$ & \begin{tabular}{rr|}
66 \\
518 \\
168 \\
120 \\
204 \\
81 \\
265 \\
974 \\
267 \\
421 \\
496 \\
835 \\
190 \\
810 \\
128 \\
229 \\
1,243 \\
780 \\
181 \\
11 \\
12 \\
196 \\
169
\end{tabular} & \begin{tabular}{r}
1 \\
6 \\
2 \\
5 \\
3 \\
2 \\
54 \\
12 \\
2 \\
2 \\
6 \\
17 \\
25 \\
105 \\
125 \\
14 \\
2 \\
12 \\
5 \\
1 \\
40 \\
12 \\
9 \\
\hdashline 1 \\
1 \\
\hdashline 1 \\
2
\end{tabular} & \begin{tabular}{rr} 
\\
\hdashline
\end{tabular} & $\begin{array}{r}1 \\
6 \\
2 \\
5 \\
72 \\
520 \\
311 \\
12 \\
2 \\
122 \\
210 \\
125 \\
294 \\
1,334 \\
439 \\
450 \\
513 \\
848 \\
200 \\
817 \\
183 \\
245 \\
1,276 \\
801 \\
216 \\
13 \\
12 \\
231 \\
218\end{array}$ & \begin{tabular}{r}
$r 43$ \\
468 \\
97 \\
92 \\
\hdashline 51 \\
182 \\
896 \\
216 \\
300 \\
495 \\
703 \\
290 \\
833 \\
166 \\
157 \\
1,451 \\
718 \\
156 \\
4 \\
26 \\
76 \\
211
\end{tabular} & \begin{tabular}{r}
1 \\
6 \\
2 \\
5 \\
3 \\
2 \\
54 \\
35 \\
2 \\
2 \\
6 \\
18 \\
25 \\
105 \\
125 \\
15 \\
2 \\
12 \\
5 \\
1 \\
40 \\
12 \\
9 \\
\hdashline 1 \\
1 \\
1 \\
1 \\
1 \\
2
\end{tabular} & 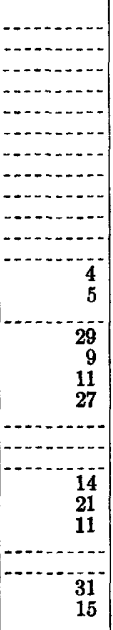 & $\begin{array}{r}1 \\
6 \\
2 \\
5 \\
46 \\
470 \\
151 \\
127 \\
2 \\
2 \\
6 \\
69 \\
211 \\
1,006 \\
341 \\
344 \\
506 \\
726 \\
322 \\
834 \\
206 \\
169 \\
1,474 \\
739 \\
168 \\
5 \\
27 \\
108 \\
228\end{array}$ \\
\hline \multicolumn{13}{|c|}{ T. 5 S., R. 2 E. } \\
\hline $\begin{array}{l}7 \\
8 \\
17 \\
18 \\
19 \\
20\end{array}$ & $\begin{array}{r}76 \\
238 \\
1,214 \\
299 \\
182 \\
410 \\
496 \\
\end{array}$ & $\begin{array}{r}6 \\
1 \\
7 \\
3 \\
26 \\
10 \\
89 \\
6 \\
2 \\
7 \\
2 \\
2\end{array}$ & $\begin{array}{r}12 \\
45 \\
199 \\
121 \\
40 \\
216 \\
\hdashline \\
\hdashline\end{array}$ & $\begin{array}{r}6 \\
1 \\
7 \\
3 \\
114 \\
293 \\
1,502 \\
426 \\
224 \\
633 \\
2 \\
496\end{array}$ & \begin{tabular}{r}
54 \\
242 \\
1,241 \\
668 \\
261 \\
904 \\
\hdashline 288 \\
\end{tabular} & $\begin{array}{r}4 \\
2 \\
5 \\
4 \\
4 \\
25 \\
1 \\
15 \\
7 \\
2 \\
3 \\
4 \\
4\end{array}$ & $\begin{array}{r}-25 \\
25 \\
152 \\
26 \\
10 \\
26 \\
\hdashline\end{array}$ & $\begin{array}{r}4 \\
2 \\
5 \\
4 \\
81 \\
268 \\
1,408 \\
701 \\
273 \\
933 \\
4 \\
288\end{array}$ & \begin{tabular}{r|r|}
-123 \\
294 \\
1,387 \\
771 \\
568 \\
146
\end{tabular} & $\begin{array}{r}4 \\
2 \\
5 \\
4 \\
25 \\
1 \\
15 \\
7 \\
2 \\
3 \\
4 \\
-\end{array}$ & $\begin{array}{r}-3 \\
\hdashline \\
12 \\
9 \\
35 \\
88 \\
\hdashline \\
\hdashline\end{array}$ & $\begin{array}{r}4 \\
2 \\
5 \\
4 \\
151 \\
307 \\
1,412 \\
787 \\
328 \\
659 \\
4 \\
146\end{array}$ \\
\hline
\end{tabular}


TABLE 24.-Water, in acre-feet, yielded annually by wells in Provo district, 1988-40

[Based on measurements and computions by State Engineer]

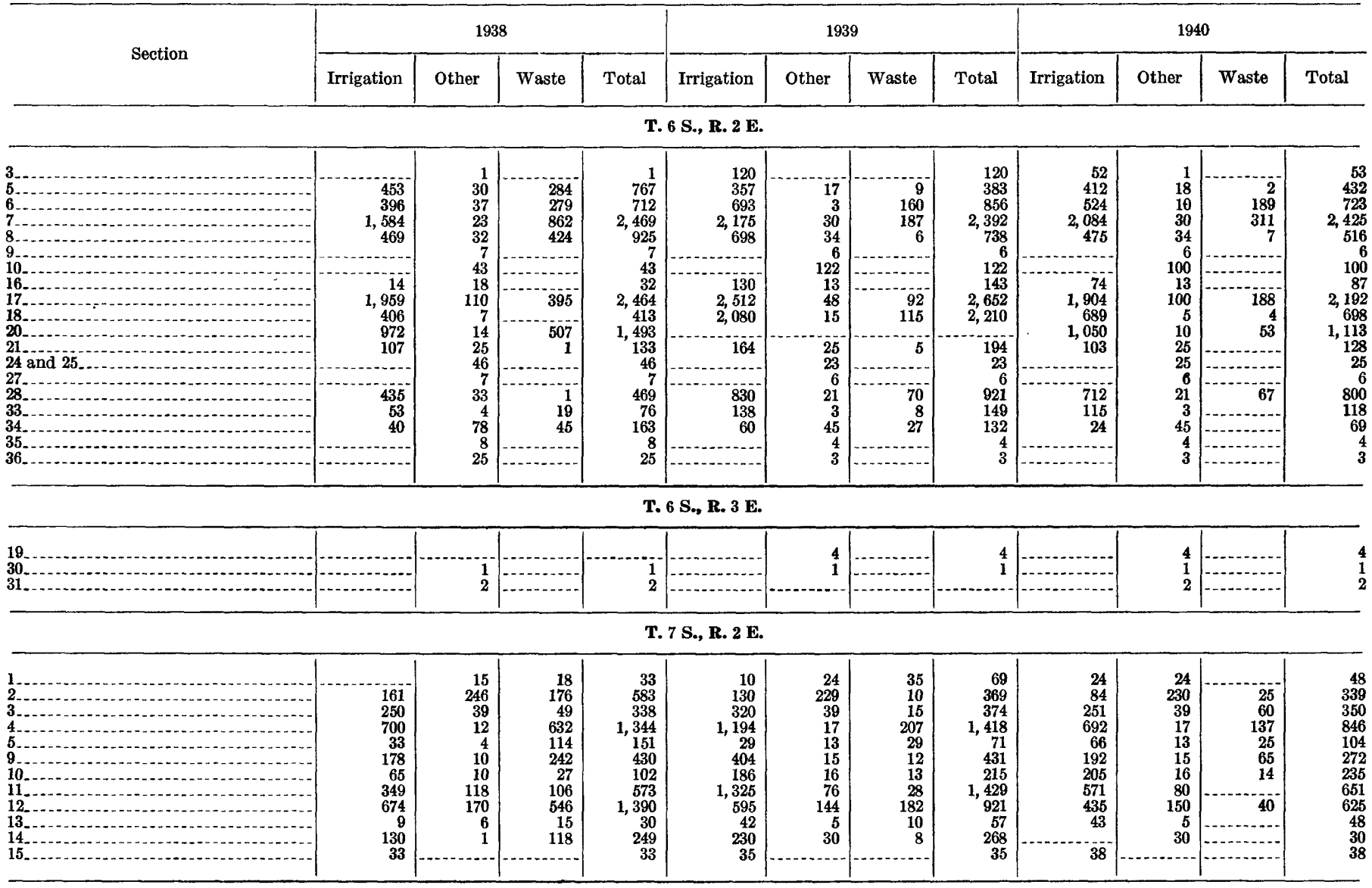

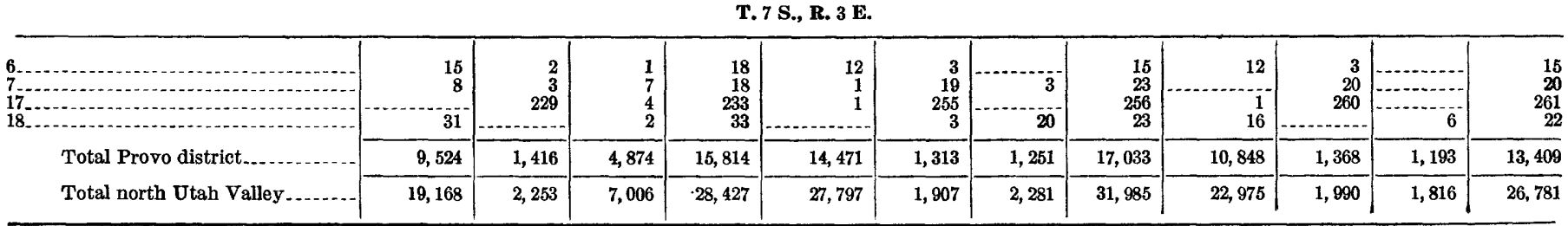




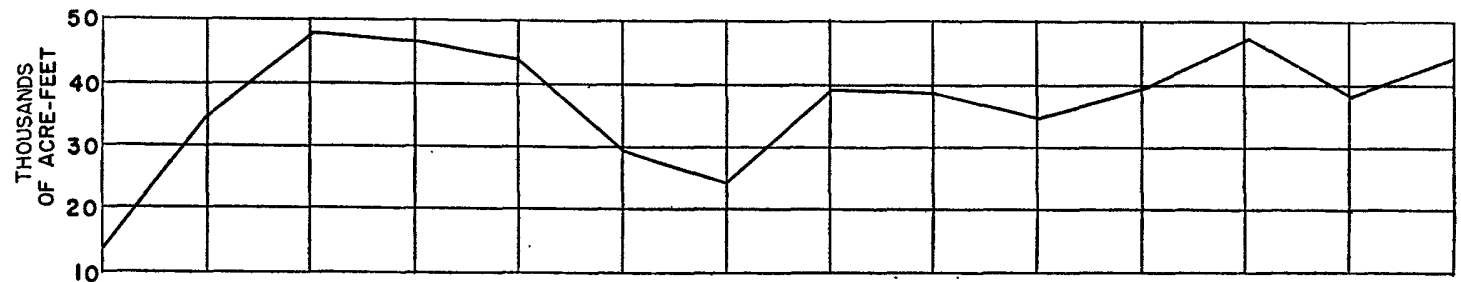

ANNUAL DISCHARGE OF AMERICAN FORK RIVER NEAR AMERICAN FORK
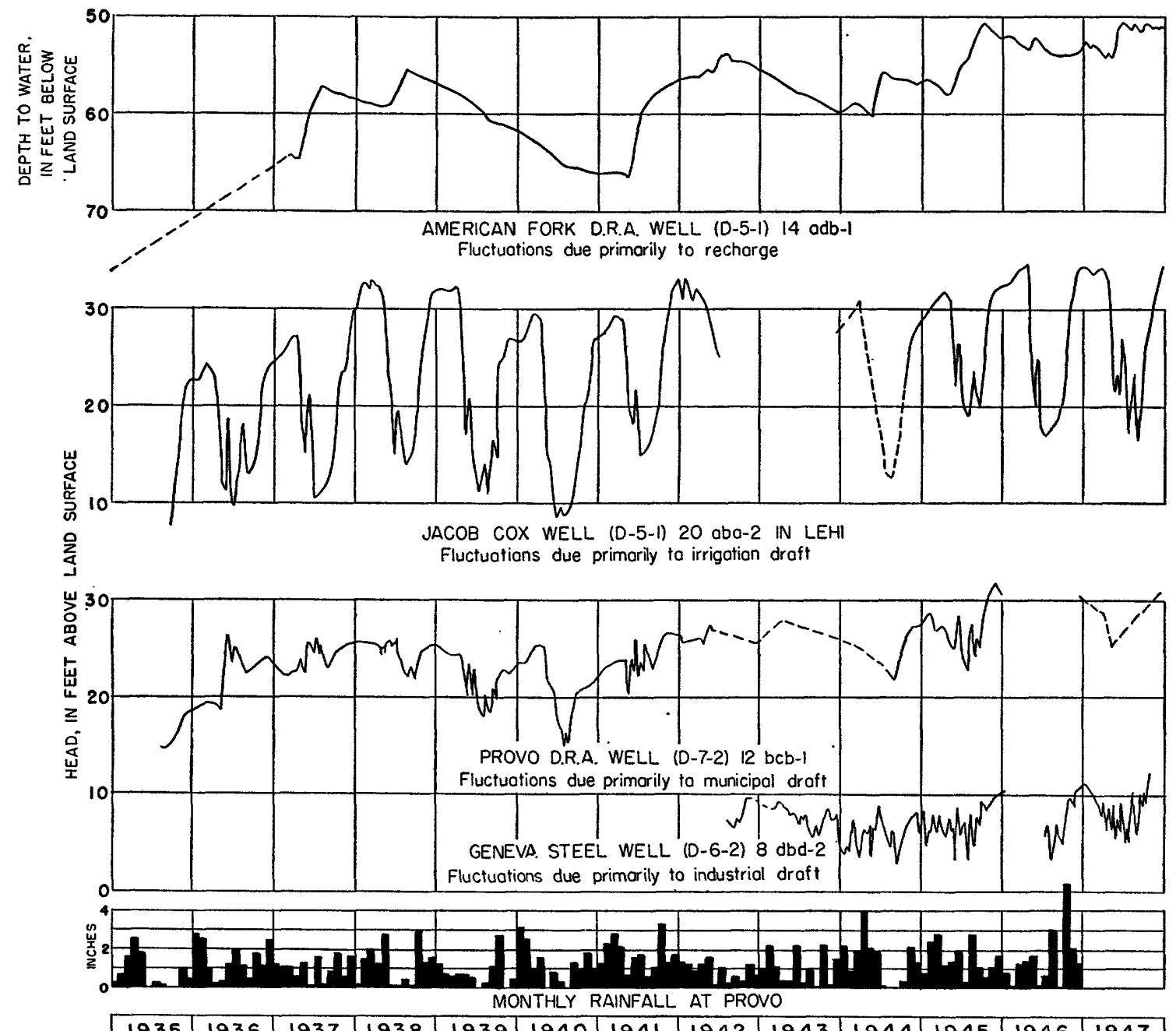

\begin{tabular}{|l|l|l|l|l|l|l|l|l|l|l|l|l|}
\hline 1935 & 1936 & 1937 & 1938 & 1939 & 1940 & 1941 & 1942 & 1943 & 1944 & 1945 & 1946 & 1947 \\
\hline
\end{tabular}

FIGURE 18.-Hydrographs of four wells in northern Utah Valley. 
FLUCTUATIONS OF WATER LEVRL AND ARTESIAN PRESSURE

The quantity of water stored in a ground-water reservoir varies from day to day, from season to season, and from year to year in response to changes in the rate at which water is taken into or discharged from the reservoir. The water level in wells-or the shut-in artesian pressure in flowin! wells-fluctuates in response to these changing conditions. The artesian pressure is a major factor controlling the rate at which a flowing well can yield water. Determination of the fluctuations in water level and artesian pressure in wells and their causes is therefore essential to understanding the capabilities of the reservoir as a source of water supply. The types of fluctuations observed in wells in northern Utah Valley are discussed briefly below. A more detailed discussion of fluctuations in a part of the area has already been published. (Taylor and Thomas, 1939, pp. 120-135).

\section{SEASONAL FLUCTUATIONS}

Fluctuations of water level have been recorded by gages installed on four wells in northern Utah Valley for periods of 5 years or more. Hydrographs for these wells, presented in figure 17, show seasonal and annual fluctuations that are typical of wells in the area.

The American Fork Drought Relief Administration well is located near the north edge of the town of American Fork. Although there are shallow wells higher on the American Fork alluvial fan, this is the highest well that reaches the pre-Lake Bonneville deposits which constitute the productive aquifers in the area of artesian flow to the south and west. The fluctuations of water level in this well are closely related to the discharge of American Fork River. In most years the water level rises sharply in May and June during the annual freshet. These are the periods of greatest recharge to the ground-water reservoir, and this well is in an area where the effects of such recharge are pronounced. In the comparatively dry years 1939, 1940 , and 1943, the stream runoff was low and recharge to the ground-water reservoir was at a minimum.

The other three wells are in the area of artesian flow, and the principal fluctuations of artesian pressure are caused by operation of flowing wells. There is, of course, no flow from the observation wells, which are equipped with pressure recorders, and the fluctuations therefore result from operation of other wells in the vicinity. The Jacob Cox well is in the midst of an area where many wells are used for irrigation; heavy draft on these wells during the irrigation season results in a decline of 10 to 20 feet in the pressure head of the observation well. The Provo Drought Relief Administration well is in the western part of Provo City where many residents have small artesian wells for domestic use: the wells are operated intermittently throughout the year, but the heavier draft for lawns and gardens in the summer commonly causes some seasonal decline of pressure in the observation well. The Geneva Steel Co. well is near the center of the plant area, and the only wells within half a mile are those used by the company for industrial purposes; this draft, though intermittent, is distributed throughout the year, and there is no pronounced seasonal cycle to the fluctuations in the observation well.

LONG-TERM FLUCTUATIONS

The close relation between water levels in wells in the recharge area and the discharge of streams is typified by the uppermost graphs of figure 18 . The general trend of the other hydrographs also reflects the trend in stream discharge, even though the dominant fluctuations result from operation of nearby wells. In general throughout the area, the discharge from artesian wells is minimum during the winter, and the graphs of figure 18 indicate that water levels are fairly stable at the end of each year. The month of December has therefore been selected for measurements in numerous observation wells throughout the valley. Hydrographs based on annual measurements in artesian wells (fig. 19) show a remarkable

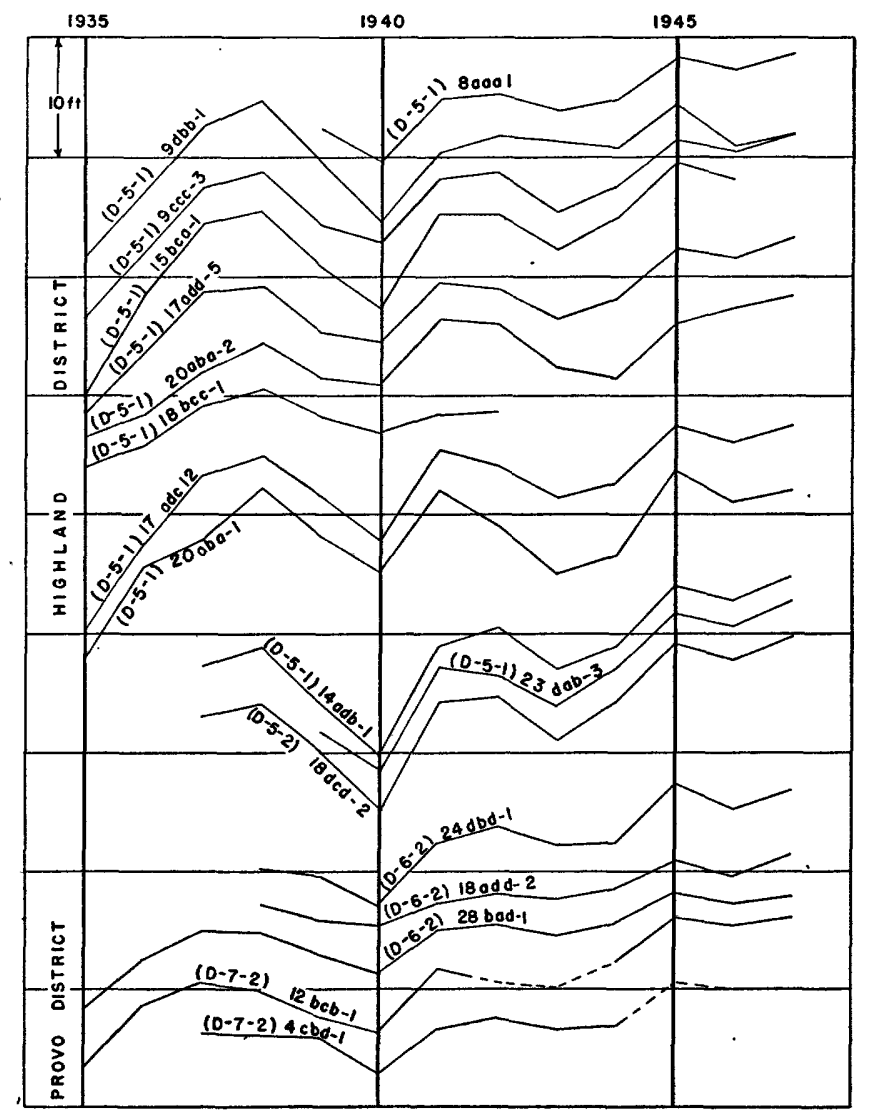

Figure 19.-Hydrographs of 17 wells that tap artesian aquifers of Pleistocens pre-Lake Bonneville deposits. 
degree of uniformity in trend, and it is likely that these changes in water level may be indicative of changes in storage in a common reservoir. These graphs, and table 25, summarizing the changes recorded in the same wells, show a general upward trend in water levels since 1935, which marked the end of a severe drought cycle in Utah. However, the water levels in all wells declined during the dry years 1939,1940 , and 1943 , and the graphs thus show a close relation to the meteorologic conditions in the drainage basin and to the runoff in streams that enter northern Utah Valley.

TABLE 25.-Changes of water levels in observation wells

\begin{tabular}{|c|c|c|c|c|}
\hline \multirow[b]{2}{*}{ Year } & \multicolumn{2}{|c|}{ Net change during year, in } & \multicolumn{2}{|c|}{$\begin{array}{l}\text { Cumulative change since 1935, } \\
\text { in feet }\end{array}$} \\
\hline & $\begin{array}{l}\text { A verage of } \\
12 \text { wells in } \\
\text { Highland dis- } \\
\text { trict }\end{array}$ & $\begin{array}{l}\text { A verage of } \\
5 \text { wells in } \\
\text { Provo dis- } \\
\text { trict }\end{array}$ & $\begin{array}{c}\text { Avverage of } \\
12 \text { wells in } \\
\text { Highland dis- } \\
\text { trict }\end{array}$ & $\begin{array}{l}\text { Average of } \\
5 \text { wells in } \\
\text { Provo dis- } \\
\text { trict }\end{array}$ \\
\hline $\begin{array}{l}1936 \\
1937- \\
1938- \\
1939 \\
1940\end{array}$ & $\begin{array}{l}+5.4 \\
+4.5 \\
+1.6 \\
+3.8 \\
-3.0\end{array}$ & $\begin{array}{r}+4.8 \\
+2.2 \\
-.3 \\
-1.3 \\
-1.8\end{array}$ & $\begin{array}{r}+5.4 \\
+9.9 \\
+11.5 \\
+7.7 \\
+4.7\end{array}$ & $\begin{array}{l}+4.8 \\
+7.0 \\
+6.7 \\
+5.4 \\
+3.6\end{array}$ \\
\hline $\begin{array}{l}1941 \\
1942 \\
1944\end{array}$ & $\begin{array}{r}+6.5 \\
-.3 \\
-2.7 \\
+1.6 \\
+4.5\end{array}$ & $\begin{array}{r}+4.0 \\
-.5 \\
-.9 \\
+.9 \\
+3.4\end{array}$ & $\begin{array}{r}+11.2 \\
+10.9 \\
+8.2 \\
+9.8 \\
+14.3\end{array}$ & $\begin{array}{r}+7.6 \\
+7.1 \\
+6.2 \\
+7.1 \\
+10.5\end{array}$ \\
\hline 1946 & $\begin{array}{l}-1.4 \\
+1.3\end{array}$ & $\begin{array}{l}-1.1 \\
+1.2\end{array}$ & $\begin{array}{l}+12.9 \\
+14.2\end{array}$ & $\begin{array}{r}+9.4 \\
+10.6\end{array}$ \\
\hline
\end{tabular}

RELATION BETWEEN FLUCTUATIONS OF WATER LEVEL AND TOTAL WELL DISCHARGE

The owners of wells drawing from several of the artesian reservoirs of Utah have a fairly regular irrigation routine, opening the wells for about the same period year after year. In these areas the total well discharge correlates fairly well with the artesian pressure as recorded in selected wells, just as discharge from an artesian spring is commonly-an indication of the pressure that produces the discharge. The total discharge from wells in such areas is greatest during years when artesian pressure is highest, and hence during years of greater-than-normal precipitation, runoff, and ground-water recharge.

A different relationship is observed in areas where wells are pumped for irrigation, or where they are used chiefly to supplement surface-water supplies. In these areas the total discharge from wells is generally greatest during dry years and when the stream flow is less than normal. In those years the water levels in wells are commonly lower than in wet years because of reduced recharge. The total discharge thus may increase concurrently with declining water levels, owing to operation of a greater number of wells for a longer season.
In the northern part of Utah Valley many wells are used to supplement surface-water supplies and in a wet year may be opened for only a very short period. Other wells constitute the sole source of irrigation water, and are used throughout every irrigation season. It might be expected that no clear relationship between total well discharge and average water levels in observation wells would be observed under these varying conditions. During the 3 years for which estimates of total well discharge have been made this lack of correlation is evident. In 1939 the discharge from wells was about 4,000 acre-feet more than in 1938, although water levels that year had declined an average of $2 \frac{1}{2}$ feet in observation wells. In 1940 the total discharge from wells was slightly greater than in 1938 and more than 3,000 acre-feet less than in 1939; the water levels in observation wells were about 5 feet lower in 1940 than in 1938.

It is obvious that for a determination of the quantities of ground water actually used each year there is at present no substitute for a complete inventory based on actual measurements of the discharge from each well.

\section{SPRINGS AND DRAINS}

Springs are the points or areas of natural discharge of ground water from the water-bearing rock materials, and "drains" carry discharge from seepage areas or areas where the water table is close to the surface. Many of these drains-whether tunnels or pipesdoubtless were constructed in order to make soggy lands arable, but in an area where water is scarce the water developed by the drains is valuable. Many drains serve principally as producers of water, and are not greatly different from "developed springs." There are scores of springs and drains in northern Utah Valley that are put to beneficial use for irrigation, stock watering, or industrial purposes; and also many spring and seep areas in the lowlands bordering Utah Lake, some large enough to discharge water seasonally or continuously into the lake and some forming swampy areas of large evapotranspiration losses.

Springs along the toe of the Orem bench discharge ground water from the sand and gravel of the Provo formation. The developed springs used by Geneva Steel Co. are examples: The Fugal Springs increase in discharge throughout the irrigation season, reaching a peak of more than $5 \mathrm{cfs}$ in October or November, then decline gradually to a minimum of 2 to $3 \mathrm{cfs}$ in the spring. Water applied for irrigation on the Orem bench is the source of a considerable part of this spring discharge, and no doubt many springs have originated, and all have increased in flow, since irrigation began more than 80 years ago. 
Most of the springs in the northern Utah Valley, including several of large flow, are in the lowlands bordering the east and north shores of Utah Lake. The belt in which the springs occur ranges in width from half a mile, west of Provo, to more than a mile near Lehi. The highest springs are as much as 30 feet above the compromise level of the lake; there are many close to the compromise level, and also some that discharge from the lake bed when the lake is at low level. Generally these springs rise where the clay member of the Provo formation is at the surface. Some discharge water that has moved through the coarser shore facies of the Provo formation. In large part, however, these springs discharge water that has

\section{SOURCES OF GROUND WATER}

Practically all the ground water used in northern Utah Valley, whether from wells or springs, is derived from unconsolidated materials of the valley fill, of Quaternary and possibly Tertiary age. Small supplies of water are also obtained from springs and tunnels along the base of the Wasatch Range, where the water is yielded by consolidated rocks; these sources are relatively unimportant to the economy of the valley, however, and are not included in the following discussion.

Some of the water-bearing formations appear at the surface, and their areas of outcrop are shown on the geologic map (pl. 1). The post-Provo alluvial deposits and the sand and gravel members of the Provo formation
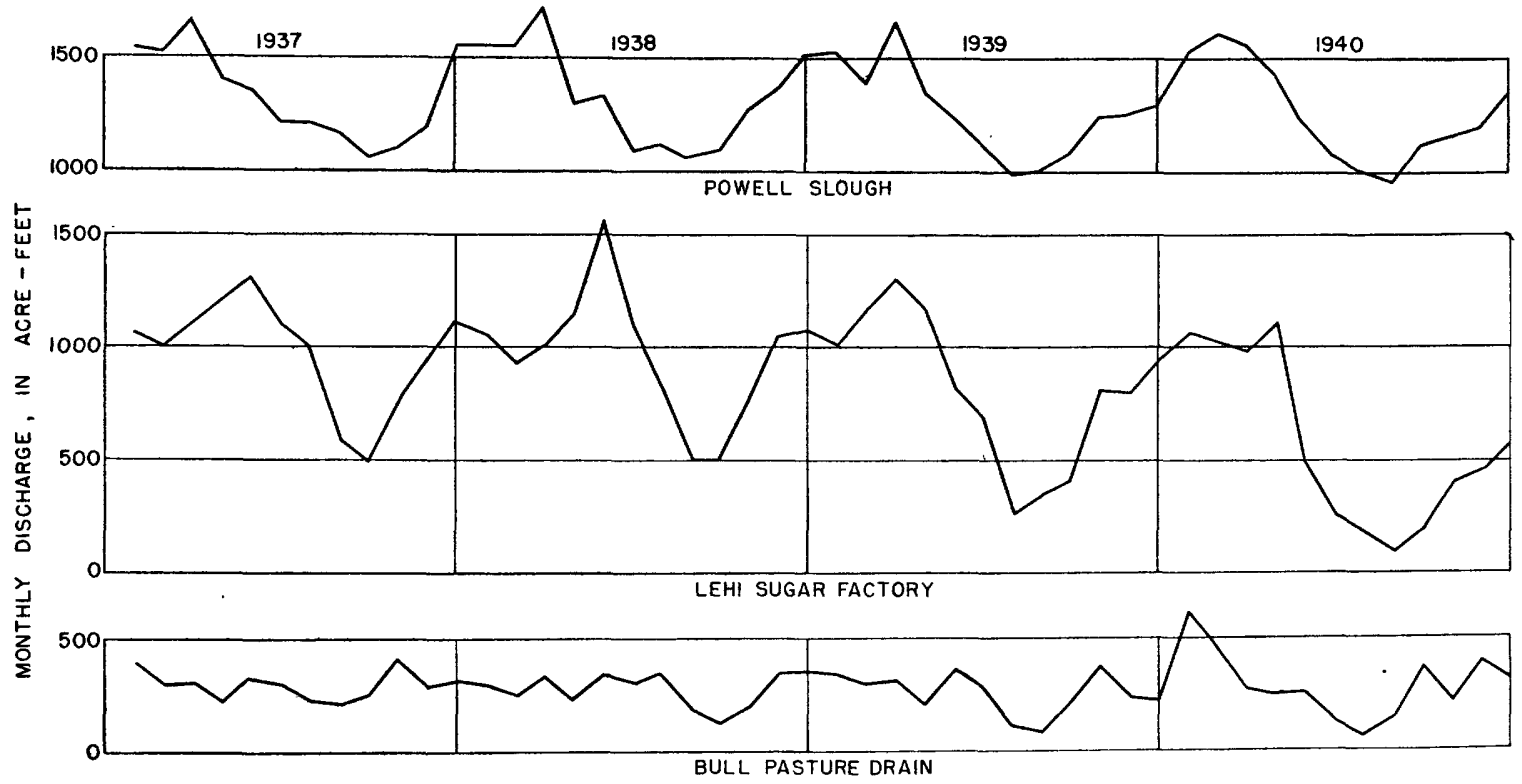

FIGURE 20.-Monthly discharge from three spring areas in northern Utah Valley, 1937-40.

moved upward through this clay from the underlying pre-Lake Bonneville deposits in which the water is under artesian pressure (see p. 85).

Hydrographs of the discharge from three spring areas are presented in figure 20 . The spring flow from each area is least during the irrigation season (June to October), when artesian pressure in the pre-Lake Bonneville aquifers is least because of the discharge from flowing irrigation wells.

Saratoga Springs, along the northwest shore of Utah Lake and three-quarters of a mile south of the outlet to Jordan River, are warm springs. The swimming pools at the resort require more water than is discharged naturally by the springs, and several wells have been drilled in the vicinity, which discharge water by artesian pressure and at a temperature of about $110^{\circ} \mathrm{F}$. It is likely that this water rises from considerable depth, possibly along faults that may extend south along the base of the Lake Mountains. probably bear some water throughout their areas of outcrop. Several wells have been dug or drilled in these deposits and yield water for domestic and stock use and for a small amount of irrigation. However, the most important water-bearing deposits in northern Utah Valley-the pre-Lake Bonneville deposits-do not appear at the surface except in a small area near Pleasant Grove. These deposits are known chiefly from well logs. Section $F-F^{\prime}$ on plate 4 is a geologic section based on well logs, extending along a line parallel to the front of the Wasatch Range from Lehi to Provo. The formations penetrated by wells along this profile include the post-Provo alluvial deposits, the Lake Bonneville group, the pre-Lake Bonneville deposits, and possibly Tertiary deposits.

\section{POST-PROVO ALLUVIAL DHPOSITS}

The post-Provo alluvial deposits form the channel beds and flood plains of the present streams, and have 
their greatest extent and thickness along Provo River, American Fork River, and Dry Creek. At the mouths of the respective canyons these post-Provo deposits consist predominantly of well-rounded but poorly sorted gravel and boulders. Downstream the average size of materials becomes generally smaller, but there is a considerable amount of gravel as far as the towns of Provo, American Fork, and Lehi. Below these towns the proportion of sand and silt increases. As shown in logs of wells near American Fork (sec. $F-F^{\prime}$, pl. 4 ), the alluvial material may be as much as 40 feet thick:

\section{WATER TABLE}

Water is generally within 25 feet of the surface in the coarse post-Provo alluvium, and is not confined. The few wells on the flood plains of American Fork and Provo Rivers indicate that the water table has a gradient approximately equivalent to that of the stream. There are too few wells, however, to provide details as to the form of the water table. It is certain that this form has been modified considerably from natural conditions by the irrigation of fields and by seepage from canals and ditches in the flood plain.

\section{RECHARGE AREA}

Water enters the alluvium by seepage from the natural channels of the streams or from unlined canals or ditches that divert the stream water across the flood plain. Some water in the alluvium may also be derived by infiltration of precipitation or from water applied for irrigation on the flood plain. Finally, irrigation on the Orem and Highland benches has caused the water table in those areas to rise until in some areas it is higher than that under the flood plains of the stream. In those areas some ground water will move from under the benchlands toward the alluvium along the streams. Thus the recharge area for the ground water in the alluvium includes the area of the stream channels and flood plains as well as the borders of those flood plains. Most of the water, however, comes by one means or another from the stream that deposited the alluvial materials.

\section{MOVEMENT AND NATURAL DISPOSAI}

The ground water in the alluvium moves toward Utah Lake. At the mouths of the stream canyons where the post-Provo alluvium is coarse-textured and permeable, it is likely that underlying and older formations are similarly permeable, and that water may enter those formations from the alluvium. Farther from the mountains, the post-Provo deposits in many places rest upon finer-textured materials, and probably there is little loss by downward percolation from the alluvium into older sediments in those reaches. Downstream from the towns of Provo, American Fork, and
Lehi, where pre-Lake Bonneville aquifers contain water under artesian pressure, the alluvium may receive water by slow upward movement through the confining layers above those aquifers.

The ground water in the alluvium eventually discharges into Utah Lake or into the streams that flow to the lake, and thus it is very closely related to the water in the stream: it enters the valley at the mouth of the same canyon, follows the same general course and eventually reaches the same destination-but makes its way at a much slower rate. Not all the ground water in the alluvium reaches the lake, however, for it may be evaporated in the areas where it is close to the surface. Also, under most of the flood plain, ground water is within reach of trees and other waterloving vegetation, and a considerable quantity is discharged by transpiration. Because of the close relation between the surface water and the ground water in the alluvium, this evapotranspiration withdrawal may be replenished by seepage from the stream, resulting in a net loss in stream flow.

\section{CONSUMPTIVE USE}

Beneficial consumptive use of water in the alluvium includes the negligible quantities of water that are drawn from wells for domestic and stock use, and the quantities taken by subirrigation of such cultivated crops as alfalfa in areas where the water table is close to the surface. By comparison the nonbeneficial consumptive "use" by native vegetation is doubtless a larger quantity. It is not possible to eliminate this nonbeneficial withdrawal, however, as long as the present stream channels and irrigation canals are used as conduits for appropriated water, because any lowering of the water table in the flood plain would result in infiltration and seepage losses from those conduits.

\section{THE PROBLEM OF POLLUTION}

Three of the largest towns-Provo, American Fork, and Lehi-have identical geological settings. Each is located on a post-Provo alluvial fan that is underlain by the silt or clay members of the Provo formation. These fans have a maximum thickness of about 50 feet; the average thickness is much less. Ground water that evidently represents the underflow from the streams at the towns moves along the base of these fans and emerges in seeps at the thinned edges of the fans. The village of Alpine is on a gravelly flood-plain deposit that overlies impermeable beds in the Alpine formation. The underflow of Dry Creek and Fort Canyon Creek moves along the base of the flood-plain deposit and emerges downstream along Dry Creek.

Pleasant Grove is located on a pre-Lake Bonneville fanglomerate on which are preserved local remnants of 
the younger and less permeable Lake Bonneville deposits. The depth to impermeable layers and ground water is considerably greater at Pleasant Grove than at the other towns.

At each of the towns and in much of the surrounding area the ground is generally favorable for the construction of cesspools and equally favorable for pollution of the shallow ground water. It should be noted, however, that each of the towns has a municipal water system that delivers potable water from other sources, and Provo has a sewer system that carries the city wastes to Utah Lake.

Dr. V. P. Sokoloff collected numerous samples of the waters at various places in the valley and tested them for the presence of nitrite which, like nitrate, is associated with organic decomposition. The tests were made by adding griess reagent (solution containing 0.2 gram of alpha naphthyl amine, 2.0 grams of sulfanilic acid, 20 grams of tartaric acid, in about 9 ounces of water) to samples of clear water. Nitrite was inferred to be present if the solution turned pink within a few minutes. Positive tests were obtained rather generally from a few dozen samples of the surface waters. Numerous seeps were tested where the water issued from the ground and many of these gave positive tests. No tests were made to determine the presence of harmful bacteria, and it is known that the inorganic products of decomposition persist under conditions - that do not support bacterial life. Nevertheless, these tests strongly suggest that the shallow ground water in many places has been polluted.

\section{LAKE BONNEVILLE GROUP}

The water-bearing properties of the Lake Bonneville group vary widely, depending upon the topographic position and the permeability of the materials. Coarse and permeable materials of the Bonneville formation and of the glacial outwash and moraines absorb water readily from precipitation, but are generally entirely above the regional water table and are therefore not saturated. The clay and silt deposits in the Alpine and Provo formations in the lower parts of the valley are largely saturated with water, but their permeability is generally so low that this water is not yielded readily to wells. The clay beds constitute the confining layers over the pre-Lake Bonneville aquifers, in which water is under artesian pressure. Although the clay is relatively impermeable it is not absolutely so, and it is probable that in the aggregate, large quantities of water move upward from the underlying aquifers and are discharged into Utah Lake by seepage or by evapotranspiration at the land surface.

The principal aquifers in the Lake Bonneville group are the gravel and sand members of the Provo and
Alpine formations. These members are most extensive under the Orem bench and under the Highland bench.

\section{WATER TABLE}

As shown by measurements in about 40 wells, the water table is generally less than 50 feet below the land surface in the wells that have been dug or drilled into the Provo and Alpine formations. The water table slopes generally in the same direction as the land surface, at a rate of 60 to 80 feet per mile. (See pl. 3.) Near the eastern border of the Orem bench the water table is from 40 to 70 feet higher than under the adjacent flood plain of the Provo River.

\section{RECHARGE AREA}

The ground water in the gravel and sand members of the Provo and Alpine formations is derived chiefly from excess irrigation water applied on the Orem and Highland benches. Precipitation upon those benches, especially winter precipitation, doubtless contributes also to the ground water. Thus the recharge area is approximately coextensive with the outcrops of those formations, and extends over the entire benchland area.

Before the beginning of irrigation on the benches some 80 years ago, the water table was considerably lower than it is today, as indicated by the records of depths at which water was encountered in early wells (Richardson, 1906, pp. 50-51). At that time the water table under the benches may well have been lower than that under the flood plains of the Provo River and American Fork River, and it is likely that water moved from these flood-plain materials into the sand and gravel members of the Provo and Alpine formations.

\section{MOVEMENT AND NATURAL DISPOSAL}

The ground water under the Orem and Highland benches moves generally southwestward, roughly parallel to the slope of the land surface and at right angles to the contours of the water table as depicted in plate 3. Some water along the eastern edge of the Orem bench doubtless moves eastward into the alluvium of the Provo River flood plain. Most of the water is discharged by springs and seeps along the edges of the benches, but some may continue underground in sandy beds of the Lake Bonneville group west of those benches and ultimately be discharged from seeps near the margin of or in the bed of Utah Lake.

\section{CONSUMPTIVE USE}

A few domestic wells still obtain water from the gravel and sand members of the Provo and Alpine formations. Several others have been abandoned since the installation of community water-supply systems. A few irrigation wells have been dug or drilled into these 
beds, some east of American Fork and others in the northern part of Orem. Most of these wells are used to supplement surface-water supplies and are therefore pumped only in dry years, and then only for a few days to a time. Some apparently have not been used for several years. The aggregate quantity of water pumped from all wells is small. Doubtless the greatest use of water from these formations has been by development of springs and drains along the outer edge of the Orem bench. (See p. 78.)

\section{PRE-LAKE BONNEVHLLE PLEIGTOCENE DEPOSITS}

The pre-Lake Bonneville Pleistocene deposits are exposed in a small area east of Pleasant Grove. (See pp. 14-17.) Elsewhere they are buried under the Lake Bonneville group, and their characteristics are known chiefly from the information that can be gleaned from well logs. These logs reveal that the pre-Lake Bonneville Pleistocene deposits probably underlie the entire valley, including Utah Lake as well as the land areas as far east as the base of the Wasatch Range. Few wells have penetrated the entire thickness of these deposits: the logs of the deep wells of the Geneva Steel Co. indicate a thickness of about 400 feet at Geneva, but near Lehi the pre-Lake Bonneville Pleistocene deposits may be only 150 or 200 feet thick, judging by the log of the railroad well (D-5-1) 5caa-2 at Cutler Junction. (See p. 13 and pl. 4, sec. $F-F^{\prime}$.)

Several geologic sections show the character of the buried pre-Lake Bonneville sediments in northern Utah Valley. Three of these sections are approximately perpendicular to the trend of the Wasatch Range, and show the gradation of sediments from the mountain front toward the central part of the valley. In section $A-A^{\prime}$ of plate 4 , boulders, gravel, and sand predominate in the northeasternmost well. Tongues of these coarse materials can be recognized as far as 5 miles to the southwest, becoming progressively thinner, and separated by increasing thicknesses of fine-grained materials. The gravel and boulder deposits thicken northeastward toward the base of the mountains. The uppermost beds have a valleyward gradient of about 50 feet per mile, decreasing toward the valley. Two sections across the Orem bench (pl. 4, secs. $B-B^{\prime}$ and $C-C^{\prime}$ ) show similarly the general westward gradient of the pre-Lake Bonneville Pleistocene deposits, but there are too few wells to show the gradation from coarse to fine sediments with increasing distance from the mountains.

The curving geologic sections of plate $4\left(D-D^{\prime}\right.$ and $\left.E-E^{\prime}\right)$ show the gradation of materials from the axis of the American Fork alluvial fan. The coarse upper beds of the pre-Lake Bonneville deposits, constituting the shallow artesian aquifer, have an average thickness of 75 to 100 feet under the 4,570-foot contour, and about 50 feet under the 4,500-foot contour. This aquifer is thicker toward the eastern end of the sections, which is closer to the mountain front and near the area of outcrop of the pre-Lake Bonneville Pleistocene deposits.

The geologic section from Lehi to Provo $\left(F-F^{\prime}\right)$ is along a line roughly parallel to the base of the Wasatch Range, and crosses the alluvial fans of Dry Creek, American Fork River, and Provo River. Both the Lake Bonneville group and the underlying Pleistocene deposits are thinnest toward the north end of this section, where they probably rest on the buried flank of the Traverse Mountains. The central part of Utah Valley, represented by the southern part of section $F-F^{\prime}$ of plate 4, was evidently deeper and lower throughout the Pleistocene, and both the Lake Bonneville group and the pre-Lake Bonneville deposits are thickest there. The pre-Lake Bonneville sediments are thicker where the section skirts the Highland bench (between Lehi and American Fork) and the Orem bench (between Geneva and Lakeview) than in the intervening areas. This increased thickness results chiefly from the greater amount of coarse sediments opposite the mouths of the principal canyons.

Throughout the area where wells have been drilled, the pre-Lake Bonneville Pleistocene deposits consist of four major units. The upper unit, upon which Lake Bonneville was formed, is predominantly coarse material, poorly sorted but relatively permeable, with some beds of clay and silt. Water in this unit has an artesian pressure sufficient to produce flowing wells in the vicinity of Lehi, American Fork, Geneva, and Provo; the unit is here called the "shallow Pleistocene artesian aquifer." The aquifer is from 75 to 100 feet thick near American Fork and Geneva, about 50 feet thick near Lehi and Provo, and thinner farther west where the water-bearing materials are predominantly sand. There is an increasing proportion of fine-textured materials to the west in this uppermost zone, and, in consequence, wells may obtain water from thin gravel tongues at various depths. These thin beds are designated separate "aquifers" by local usage; there may be a slight difference in artesian pressure of the individual beds, and no evidence of interference between wells of slightly different depths. In general, however, the hydrologic characteristics of the entire zone are fairly uniform, and quite distinct from those of deeper water-bearing zones.

Beneath the shallow Pleistocene artesian aquifer there is a unit of predominantly fine-textured material, commonly 50 to 75 feet thick. In logs of the wells of the Geneva Steel plant (fig. 5) this unit is about 90 feet thick and consists of an upper and lower unit of clay separated by about 30 feet of gravel. The fine- 
textured material may be silty or even sandy near the mountains, but under most of the valley it is made up of blue clay-sized particles, similar to those of the lakebottom sediments of Lake Bonneville and inferred to be, similarly, of lacustrine origin. The materials are dominantly calcium carbonate, and are evidently a "rock flour" derived from the limestone formations of the tributary drainage basin.

The deep Pleistocene artesian aquifer underlies this lake clay and, judging by well logs, is ordinarily 75 to 150 feet thick. Its top is commonly more than 200 feet beneath the land surface, but near Lehi it is less than 150 feet below the surface owing to the thinning of all sediments along the flank of the Traverse Mountains.

Beneath the deep Pleistocene artesian gquifer is another zone of lacustrine clay, encountered in the deepest well of the Geneva Steel Co. between depths of 420 and 490 feet. No similar lake clays were penetrated in the lower 340 feet of this well. There were therefore at least three and perhaps four periods during which the valley was occupied by a lake, the last of which was Lake Bonneville; these three or four periods were separated by intervening periods during which the streams deposited alluvial materials over the valley floor. These alluvial materials include the coarse, permeable zones which supply nearly all the water yielded by wells in the valley.

\section{SHALIOW PLEISTOCEN ARTESIAN AQUIFER}

When wells are drilled through the Lake Bonneville group and into the shallow artesian aquifer of the preLake Bonneville deposits, the water rises above the top of that aquifer, and in the great majority of wells drilled to date it has risen high enough to flow at the land surface. This upward pressure exists because the overlying Lake Bonneville group is relatively impermeable and confines most of the water within the aquifer. The aquifer is saturated at all times beneath this confining layer. Nevertheless there is movement of water within the aquifer from places of high hydrostatic head toward places of lower head.

\section{PIEZOMETRIC SURFACE}

If the casings of all wells were extended high enough to prevent flow from the wells, the level to which water would rise in each well represents a point on the artesianpressure surface or piezometric surface of the aquifer. The form of this piezometric surface varies from day to day, from season to season, and from year to year, in response to the rates at which water is recharged into or discharged from the aquifer. A flowing well creates a depression in this pressure surface, toward which water moves as long as the well continues to flow. For this reason, the form of the piezometric surface under natural conditions can best be determined when discharge from wells is at a minimum.

In April 1947, prior to the irrigation season, measurements were made of the water level in nonflowing wells and of the shut-in pressure of flowing wells. The piezometric surface of the shallow artesian aquifer, constructed on the basis of measurements in about 120 wells, is shown on plate 3 . The area of artesian flow, in the central and lowest parts of the valley, is the area in which the piezometric surface is higher than the land surface.

In general, the piezometric surface is lowest near Utah Lake, and rises to the east and north with an average gradient somewhat less than that of the land surface. The piezometric surface does not conform in detail with the topographic surface, however. It is flattest under the Highland and Orem benches, where the gradient is commonly only from 10 to 20 feet per mile in the coarse sediments opposite the mouths of the larger canyons. It is steepest near the shore of Utah Lake, where the gradient may exceed 40 feet per mile. This higher gradient may be indicative of lesser permeability and generally finer texture of the aquifer at greater distance from the mountains.

The piezometric surface has the form of a series of sloping ridges and intervening embayments. The ridges follow the axes of the alluvial fans of Dry Creek and American Fork River and there are two opposite the mouth of Provo Canyon, one at the city and one extending west under Provo bench. The embayment of the piezometric surface between Lehi and American Fork may have been caused by the discharge from springs at the Lehi Sugar Factory. The embayment along the toe of the Provo bench and the steep gradient to the west are probably indicative of spring discharge from the shallow artesian aquifer into Powell Slough.

The direction of movement of water in the shallow artesian aquifer is at right angles to the contours drawn on plate 3. These contours show that water moves down the axis of each of the principal streams, and also outward from these axes. The westward slope of the piezometric surface continues past the areas where large quantities of water are taken from wells, and on to the westernmost wells, along the shore of Utah Lake. Thus it is clear that this gradient has not resulted from well discharge but is a product of natural conditions under which there has been discharge from the aquifer in the central and lowest part of the valley (under Utah Lake) for a long period of time.

\section{CONSUMPTIVE USE}

The shallow artesian aquifer is the source of most of the water yielded by wells in northern Utah Valley. 
More than 80 percent of the wells are less than 200 feet deep, and most of these tap the shallow artesian aquifer. In the vicinity of Lehi, however, that aquifer is within 50 to 100 feet of the surface, and is no longer an important producer. Most of the early wells bored to this aquifer have long since ceased to flow, and therefore near Lehi the majority of productive wells today tap the deep Pleistocene aquifer.

\section{DEEP PLEISTOCENE ARTESIAN AQUIFER}

\section{PIEZOMETRIC SURFACE}

The piezometric surface of the deep Pleistocene artesian aquifer (pl. 3) is generally higher than that of the shallow artesian aquifer, as shown by measurements in about 110 wells in April 1947. The generally higher pressure in the deeper aquifers is well known, and many well owners have found that the advantage of higher pressure or greater flow more than offsets the higher cost of drilling the deep well. The forms of the piezometric surfaces of the deep and shallow aquifers are similar in that they rise from the central part of the valley toward the mountain front. The piezometric surface of the deep aquifer also in all probability has a slighter gradient under the Highland and Orem benches than at lower altitudes in the valley, but there are no wells in these areas to provide confirmatory evidence. The contours of the deep aquifer arch around the Provo bench and suggest that water in the aquifer fans out from the mouth of Provo Canyon. Along the edge of this broad mound there are two embayments, probably produced by discharge from wells in Geneva and in Lakeview.

The piezometric surface of the deep Pleistocene aquifer under the alluvial fans of Dry Creek and American Fork has the form of a single broad southwest-sloping ridge. Whereas the piezometric surface for the shallow aquifer indicates movement along and outward from axes under Dry Creek and under American Fork River, the contours for the deep aquifer indicate movement outward from a single axis that trends southwestward from the Highland bench. The shape of the piezometric surface of the shallow aquifer is readily explained by movement in separate alluvial fans formed respectively by Dry Creek and American Fork River, both conspicuous in the present physiography. The contrasting form of the piezometric surface of the deep aquifer suggests that the deeper aquifer is a single alluvial fan, and that when it was formed Dry Creek and American Fork River were combined in one stream below the mouths of the two canyons.

The contrasting forms of the two piezometric surfaces result in a marked difference in head in sec. 21, T. $5 \mathrm{~S}$., R. 1 E., where the bulge in the piezometric surface for the deep aquifer coincides with the embayment in the surface for the shallow aquifer between the Dry Creek and American Fork River fans. There the artesian pressure of wells reaching the deep aquifer is nearly 50 feet higher than that of wells in the shallow aquifer. Because this area is low topographically, the deep artesian wells have shut-in pressures 60 to 80 feet above the land surface, the highest in Utah Valley.

CONSUMPTIVE USE

Many of the wells that yield water from the deep artesian aquifer are south and west of Lehi, where most are used for irrigation. The effect of withdrawal from these wells is shown on plate 3 by the curvature of the 4,530- to 4,565-foot contours. The effect of well discharge is much more pronounced during the irrigation season. (Taylor and Thomas, 1939.) Wells at the Geneva Steel Co. plant also draw large quantities of water from this deep aquifer, and have caused an embayment in the piezometric surface in sec. 8, T. $6 \mathrm{~S}$, R. 2 E. Other deep wells are distributed along the belt from Lehi to Provo, many of them close to the limit of artesian flow for the shallow aquifer.

\section{RECHARGE AREAS}

The piezometric surfaces for both the steep and shallow Pleistocene artesian aquifers, as mapped on plate 3 , rise toward the east and indicate that the recharge area is in that direction. But these piezometric surfaces cover only the area in which the water is confined under artesian pressure, and do not extend eastward into the recharge area. Toward the east the confining layers above the artesian aquifers grade into coarser materials, and thus cease to be confining layers. In the recharge area, from which water enters the artesian aquifers, water in coarse sediments of Lake Bonneville and pre-Lake Bonneville age is probably unconfined. This recharge area is probably limited to the mouths of the canyons and perhaps to a narrow band along the base of the range. The canyon streams are the principal source of water that enters these coarse deposits, for in wells near the recharge area the water level rises markedly during the period of peak stream discharge, and the amount of rise is related to the quantity of water discharged during the annual freshet. (See fig. 18.)

Most of the wells in the northwest part of the valley reach the deep Pleistocene artesian aquifer, and the piezometric surface of that aquifer can be delineated as far as a mile west of the Jordan River. This surface slopes westward at least to the westernmost well in the area, and it is concluded that the water even along the western border of the valley comes from the east side of the valley. Thus there is no evidence that any 
appreciable quantity of ground water enters Utah Lake Valley from the small drainage basin north of the Lake Mountains. From the small amount of stream flow and precipitation along the entire west side, it is inferred that negligible quantities of ground water originate on that side of the valley.

\section{MOVEMENT AND NATORAL DISPOSAL}

The ground water that enters the recharge areas along the east flank of the valley moves westward through the pre-Lake Bonneville deposits. The movement is most rapid through the coarse gravels and boulders near the mountains, and slower farther west where those beds grade into materials of finer texture; a greater hydraulic gradient is required to force the water through those finer sediments. The least permeable materials, especially the clay-sized particles, act as confining layers above the beds of coarser materials, creating artesian pressure within the several aquifers. Near the lower margins of the shore deposits of the Lake Bonneville group this artesian pressure is sufficient to produce flowing wells.

Water is discharged naturally from the pre-Lake Bonneville aquifers within the area where flowing wells are obtained and where, therefore, the piezometric surface is above the land surface. The springs at the Lehi Sugar Factory and around Powell Slough probably discharge water that comes chiefly from the shallow artesian aquifer, for sizable embayments in the piezometric surface indicate that water is lost from the aquifer in those areas. The deep artesian aquifer appears to contribute to the Sugar Factory springs also.

Probably the greatest amount of natural discharge from these aquifers, however, is by upward seepage of water through the so-called impermeable beds deposited on the floor of Lake Bonneville-seepage at an exceedingly slow rate, perhaps, but over so extensive an area that the aggregate discharge is large. Studies have not been made in Utah Valley to ascertain the rate of upward movement, or even to prove that there is such seepage. It is inferred to be an important item, however, on the basis of (1) the conclusion from studies in Cache Valley (Israelsen and McLoughlin, 1942, pp. 11-15) that there is upward seepage through similar clays at a rate of more than $200 \mathrm{gpm}$ per square mile of area; (2) the fact that the gradient of piezometric surfaces of both deep and shallow Pleistocene aquifers continues to the shore of the Utah Lake, indicating natural discharge farther west (pl. 3); and (3) the evidence that Utah Lake receives far more water than is measured in inflowing streams (pp. 69-72). The question of upward movement from artesian aquifers is treated further on pages 87-89.
TERTIARY AND TERTIARY(?) DEPOSTTS

Information concerning the water-bearing properties of Tertiary deposits is nearly all obtained from well (D-6-2)8bcd-4, as of 1949 the deepest well of the Geneva Steel Co. (See figs. 5 and 21.) This well draws water from strata several hundred feet below the aquifers of the Pleistocene pre-Lake Bonneville deposits. The strata considered to be of Tertiary age are encountered below the depth of 490 feet. They consist predominantly of gravel, with thinner beds of sand, and a few thin beds of clay. Clay-sized particles also make up an appreciable proportion of the poorly sorted materials encountered at depths of 530 to $\mathbf{5 7 5}$ feet, and 720 to $\mathbf{7 4 5}$ feet. The sediments appear to be dominantly of fluvial origin, but some of the beds of well-sorted sand may be eolian. Plant materials at several horizons are indicative of subaerial accumulation.

The deposits in the Geneva well that are believed to be Tertiary include four or more aquifers separated by relatively impermeable strata. These aquifers are composed dominantly of gravel, with some sand, as identified in the driller's $\log$ and in sample cuttings. Three zones of permeable strata are confirmed by the electric log that was made of the lower 200 feet of hole after casing had been cemented in to a depth of 618 feet. The deepest aquifer, 746 to 818 feet below the land surface, was developed for water supply. The completed well had 16-inch casing, grouted, to a depth of 618 feet; lead plug at the joint between 16-inch and 12-inch casings; 12-inch casing from 618 to 744 feet; 12 -inch reinforced well screens from 744 to 808 feet; and solid 12-inch casing to bottom of hole at 828 feet.

\section{CHARACTERISTICS OF DEVELOPED AQUIFER}

The driller reported sand and gravel between depths of 746 and 788 feet and gravel and boulders from 788 to 810 feet. A bed of sand and gravel between 810 and 818 feet is also a part of the aquifer, but the electric log indicated that this deepest part was somewhat less permeable, and screens, therefore, were not set in the lower 10 feet of the aquifer. The aquifer is underlain and overlain by beds of clay-sized material, of which calcium carbonate is a major constituent.

Samples of the water-bearing sediments collected at 5 -foot intervals during the drilling consist predominantly of rock fragments broken by the rotary rig. In the zone between depths of 788 and 810 feet some fragments are as large as an inch across and evidently came from boulders that probably exceeded 6 inches in diameter. Fragments of gray quartzite constitute from 45 to 60 percent of each sample and fragments of limestone make up an additional 35 to 45 percent. Other rock fragments identified include green quartz- 
ite, purple quartzite, black shale, and andesite, all of which are derived from rocks that crop out in the drainage basin of the Provo River. The position of the well opposite the mouth of the Provo River canyon also indicates that the sediments were deposited chiefly by the Provo River. All samples contain quartz sand in quantities ranging from 3 to 10 percent of the total sample.

DISCHARGE TEST OF WELL (D-6-2)8bed-4

For testing purposes, a discharge pipe with gate valve was connected to the horizontal arm of a $T$ on the casing, and the vertical arm of the $T$ was extended and covered to permit installation of a pressure gage. Measurements of the discharge of the well were made over a 1.5-foot Cipoletti weir. Immediately after completion of the well, the discharge is reported to have been $350 \mathrm{gpm}$ by natural flow. The well was then treated with dry ice, and the discharge was increased to a reported $1,400 \mathrm{gpm}$. For a period of several weeks the well flowed freely except for a few moments each day when it was closed to measure the shut-in pressure. During this period the discharge was at an essentially constant rate, as reported by engineers of the Geneva Steel Co., and the daily measurements showed only a slight fluctuation of shut-in pressure.

On April 16,1948, three weeks after completion of drilling, and after the well had been flowing for several days, a multiple-step drawdown test of the well was made. The first operation involved the closing of the well for 35 minutes and the determination of the recovery curve. Subsequently the well was opened sufficiently to discharge at a rate equivalent to onefourth of its free flow, then one-half, and then threefourths of its free flow, for periods of an hour each; finally the valve was opened fully and the flow was measured for 10 minutes. The results of these operations are summarized in table 26, and details are shown graphically in figure 21 .

TABLE 26.-Multiple-step drawdown test of Geneva Steel Co. well (D-6-2) 8 bcd-4 A pril 16, 1948

\begin{tabular}{|c|c|c|c|c|c|}
\hline \multirow{2}{*}{ Operation } & \multirow{2}{*}{$\begin{array}{l}\text { Period, } \\
\text { in } \\
\text { minutes }\end{array}$} & \multirow{2}{*}{$\begin{array}{l}\text { Average } \\
\text { discharge } \\
\text { in } \\
\text { period, } \\
\text { efs }\end{array}$} & \multirow{2}{*}{$\begin{array}{l}\text { Temper- } \\
\text { ature in } \\
\text { degrees } \\
\text { F. }\end{array}$} & \multicolumn{2}{|c|}{$\begin{array}{l}\text { Head, in feet, above } \\
\text { level of free fiow }\end{array}$} \\
\hline & & & & $\begin{array}{l}\text { Begin- } \\
\text { ning of } \\
\text { period }\end{array}$ & $\begin{array}{l}\text { End of } \\
\text { period . }\end{array}$ \\
\hline $\begin{array}{l}\text { Well closed } \\
\text { Valve } 1 / 4 \text { open } \\
\text { Valve } 1 / 4 \text { open } \\
\text { Valve } 3 / 4 \text { open } \\
\text { Well open }\end{array}$ & $\begin{array}{l}35 \\
60 \\
60 \\
60 \\
10\end{array}$ & $\begin{array}{l}0.0 \\
.75 \\
1.45 \\
2.15 \\
2.8\end{array}$ & $\begin{array}{l}70.3 \\
70.5 \\
70.6 \\
70.7\end{array}$ & \begin{tabular}{l|}
35.9 \\
32.3 \\
26.2 \\
15.45 \\
\end{tabular} & $\begin{array}{l}36.2 \\
32.05 \\
26.1 \\
15.1 \\
.0\end{array}$ \\
\hline
\end{tabular}

When the well was closed the recovery was very rapid; within 90 seconds of closing the head was 36.0 feet above the flow line, and in the next $33 \frac{1}{2}$ minutes there was an increase in head of only 0.2 foot. In each stage of the test the rate of discharge remained constant within the limits of accuracy of the weir, and no valve changes were necessary to maintain uniform discharge. After the initial decline, which occurred abruptly each time the valve was opened wider, the head decreased only a few tenths of a foot during each hour of constant discharge.

Certain characteristics of the aquifer and the well are determined from the test, on the basis of formulas

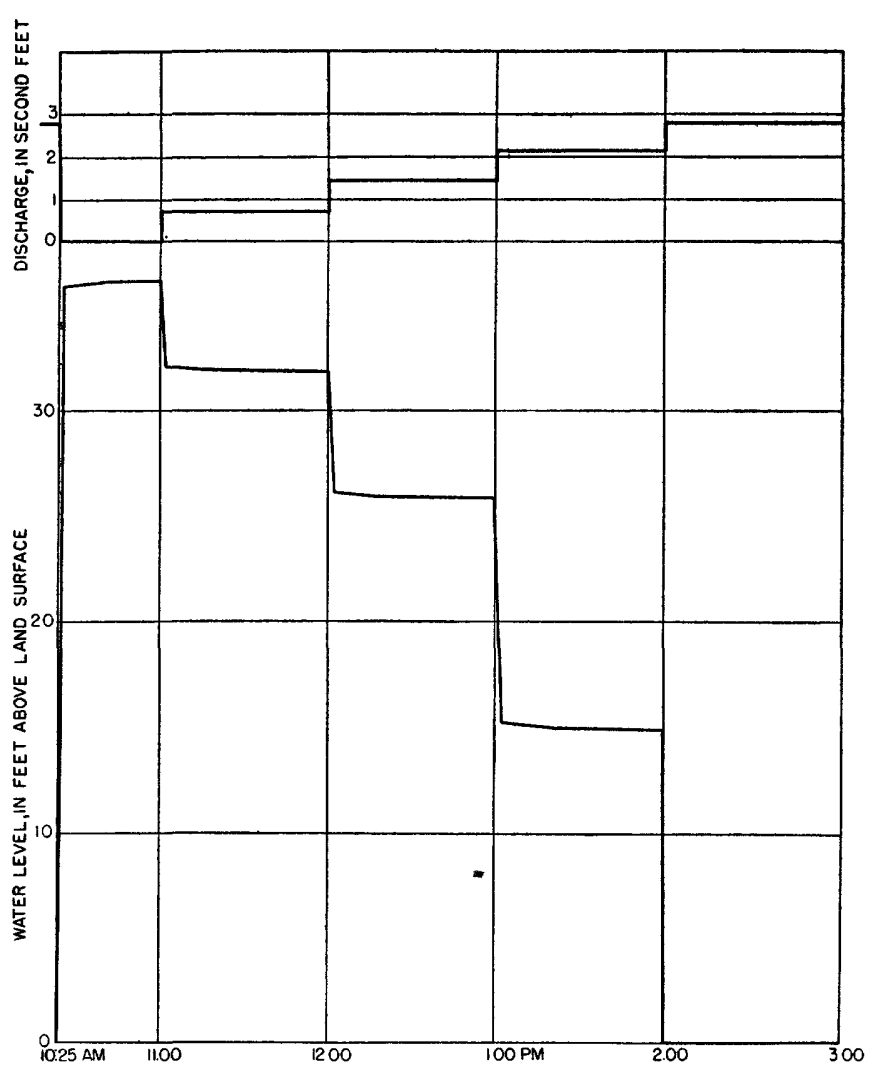

Fiqure 21. Discharge and drawdown during test of well (D-6-2)8bed-4, April 16, 1948.

derived by Jacob (1946, pp. 1047-1063). The transmissibility of the aquifer is derived by the formula

$$
T=\frac{2.30 Q \log _{10}\left(\frac{t_{2}}{t_{1}}\right)}{4 \pi\left(s_{2}-s_{1}\right)}
$$

in which $s_{2}$ and $s_{1}$ represent the drawdown in feet at times $t_{2}$ and $t_{1}$, and $\mathrm{Q}$ is the discharge in second-feet during the test period. For the period when the well was discharging $2.15 \mathrm{cfs}$ (sec-ft), or $965 \mathrm{gpm}$, the transmissibility was computed to be $0.20 \mathrm{cfs}$ (about 130,000 gallons per day) per foot width of aquifer at unit (100-percent) hydraulic gradient. Taking the effective thickness of the aquifer as the 60 -foot screened portion, the permeability is computed to be about 
2,200 gallons per day per square foot at unit hydraulic gradient. However, it is not certain that gravels above and below those screened did not contribute water to the well; if they did, the average permeability of the 60-foot section is less than 2,200.

When the well is flowing freely at the rate of $2.8 \mathrm{cfs}$ $(1,250 \mathrm{gpm})$, the apparent specific capacity is about 35 gpm per foot of drawdown. No other wells reached this aquifer at the time the test was made, and therefore no determinations were made of the hydraulic gradient or of the rate of movement of water through the aquifer.

\section{SOURCE AND MOVEMENT OF WATER IN TERTIARY(?) AQUIFERS}

Throughout most of northern Utah Valley there are no wells tapping the Tertiary(?) aquifers, and therefore no data concerning the form of the piezometric surface. West of Lehi, however, measurements were made of the shut-in pressure in seven wells that reach Tertiary(?) deposits. The piezometric surface shown by these measurements (pl. 3) has a westward gradient of about 25 feet per mile, about the same as the piezometric surface of the deep Pleistocene aquifer. The Tertiary(?) aquifer has an artesian pressure generally 5 to 10 feet higher than that of the deep Pleistocene aquifer; but where the pressure of the deep Pleistocene aquifer has been lowered by well discharge (in part because of wells permitted to flow continuously) the piezometric surface of the Tertiary(?) aquifer may be as much as 20 feet higher.

In the Geneva area, the general pattern of accumulation of valley sediments described in preceding chapters, and the hydrologic data obtained for overlying aquifers accumulated under similar conditions, indicate that the water comes from the east-probably from the canyon of the Provo River.

Any valid conclusions as to the source and movement of water in the Tertiary(?) aquifers penetrated by the deep Geneva Steel Co. well must offer a satisfactory explanation for the comparatively low mineral content of those waters. The water from the deep well has less dissolved solids than the water from any of the overlying aquifers, and less than is carried by the Provo River at low stages. Table 27 summarizes the analyses in relation to depth from which water is obtained. The waters in aquifers of different depths have similar relative proportions of chemical constituents, but these differ in concentration, as shown in figure 22.

The waters in the Tertiary(?) strata are evidently far less mineralized than that of the Provo River at low stages but are not notably different from the waters of numerous springs that rise in the Wasatch Range and flow to the Provo River. It is likely that during the spring freshet the water in the river is far less
TABLE 27.-Mineral content and hardness of water in streams, and in aquifers of various depths at Geneva, Utah

\begin{tabular}{|c|c|c|c|c|}
\hline Source of water & $\begin{array}{l}\text { Depth } \\
\text { in feet }\end{array}$ & Description & $\begin{array}{c}\text { Total } \\
\text { hardness } \\
\text { as } \\
\mathrm{CaCO}_{8} \\
\text { (ppm) }\end{array}$ & $\begin{array}{l}\text { Dis- } \\
\text { solved } \\
\text { solids, } \\
\text { ppm }\end{array}$ \\
\hline $\begin{array}{l}\text { Provo River (Mar. 30-43) } \\
\text { Bridal Veil Spring (July } \\
\text { 31-46). }\end{array}$ & & $\begin{array}{l}\text { Stream at low stage... } \\
\text { Mountain spring... }\end{array}$ & $\begin{array}{l}246 \\
100\end{array}$ & \\
\hline $\begin{array}{l}\text { Upper Falls Resort Spring } \\
\text { (July 31-46). } \\
\text { Geneva well } 5 \text {. }\end{array}$ & 130 & Shallow Pleistocene & $\begin{array}{r}90 \\
255\end{array}$ & \\
\hline $\begin{array}{l}\text { Geneva well 8... } \\
\text { Geneva well 9. }\end{array}$ & $\begin{array}{l}192 \\
285\end{array}$ & Deep Pleistocene & $\begin{array}{l}233 \\
147\end{array}$ & \\
\hline $\begin{array}{l}\text { Geneva well 14 } \\
\text { Do._. } \\
\text { Do } \\
\text { Do. } \\
\text { Geneva deep well- }\end{array}$ & $\begin{array}{r}340 \\
440 \\
639 \\
707 \\
746-818\end{array}$ & $\begin{array}{l}\text { Tertiary (?) aquifer } \\
\text { To } \\
\text { do }\end{array}$ & $\begin{array}{r}141 \\
168 \\
58 \\
88\end{array}$ & 21 \\
\hline
\end{tabular}

mineralized than at low stages, but periodic sampling and analyses have not been made. It is conceivable that water having the chemical composition of that in the Tertiary (?) aquifers could be drived from the Provo River drainage basin under present hydrologic conditions. For an explanation of the increased concentration at shallower depths, however, it is necessary to consider other factors related to ground-water movement.

Measurements of the artesian head in adjacent wells of different depths - or of the heads for different aquifers encountered during construction of a well-show that the water in the deep aquifers is under considerably greater head than that in shallow zones. During the cable-tool drilling of the Geneva Steel Co. well (D-6-2) 8 bcd-2 in 1943, the head of the water in the deep Pleistocene aquifer at depths of 285 to 460 feet was determined to be 20 feet greater than in the shallow aquifer of lesser depth. The differential head between the Tertiary(?) aquifers from 633 to 707 feet deep and the deep Pleistocene aquifer was 2 feet at that time. In 1948 when the deep well was drilled, the differential head between deep and shallow Pleistocene aquifers had decreased to about 17 feet, and that between Tertiary(?) and the deep Pleistocene aquifers had increased to about 5 feet, presumably because the head in the deep Pleistocene aquifer had been reduced by interference of several wells that were flowing during the 1948 measurements.

Differential head in adjacent wells that tap aquifers of different depths has commonly been attributed to structural or stratigraphic conditions-as, for instance, in areas where the strata are inclined, the deeper aquifers crop out at higher altitudes than do the shallow beds. Also, in certain localities of the Lake Bonneville basin the Tertiary(?) sediments crop out on mountain flanks above the highest shore line of Lake Bonneville, and the head in wells reaching those sediments may be higher than in adjacent wells tapping Pleistocene strata. 


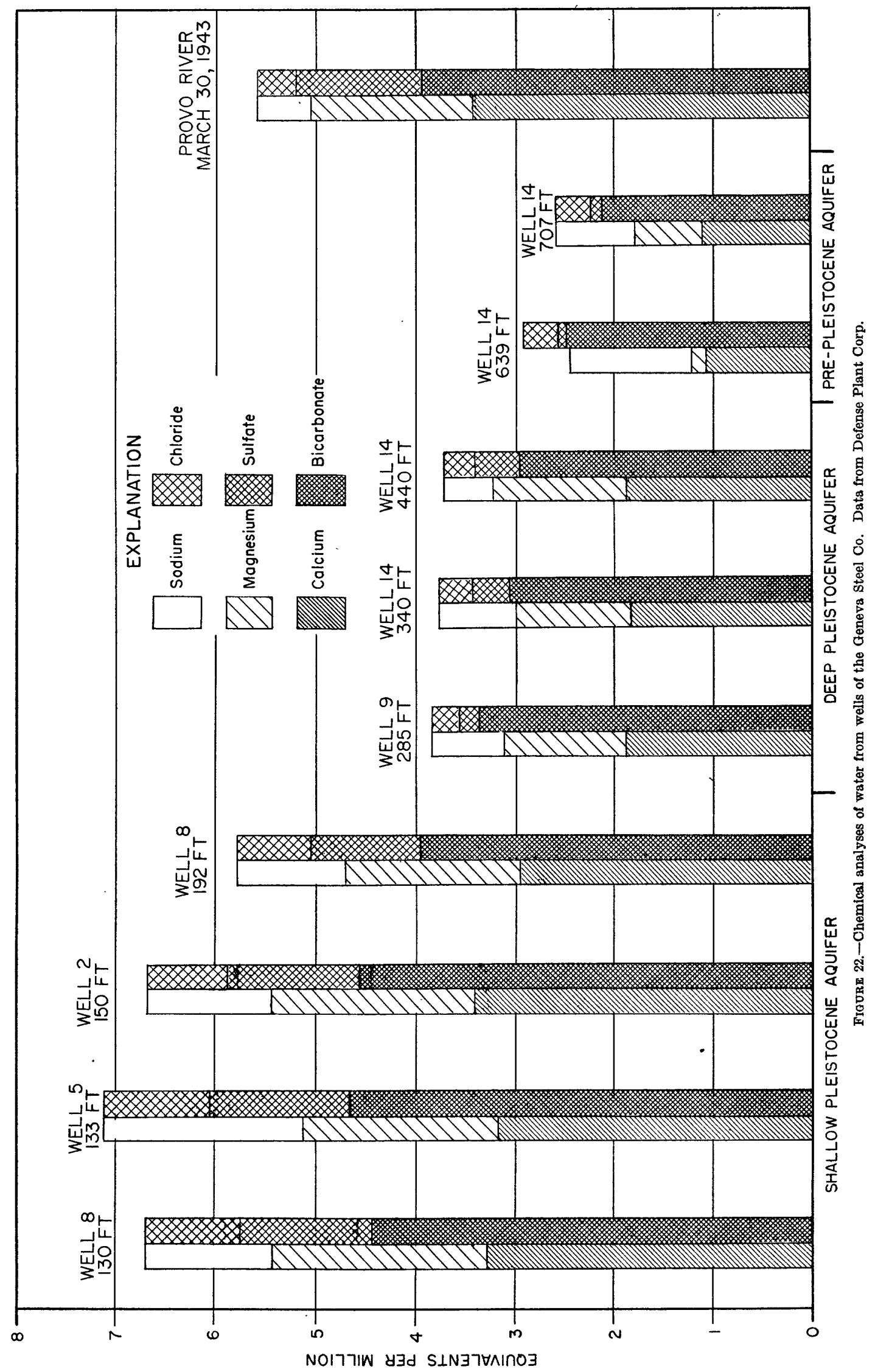


In Utah Valley, however, the Lake Bonneville group laps against the Paleozoic rocks of the Wasatch Range, and there are no higher outcrops of earlier Pleistocene or Tertiary(?) strata. Furthermore, in the long history of accumulation of the fill in Utah Valley, there is no basis for assuming that the coarse detritus of the earliest deposits would be higher on the mountain flank than that of more recent deposition. Instead, during this time the increasing thickness of valley fill would develop a valley floor of progressively increasing width, with the result that the zone of deposition of the coarser detritus-the prime water-bearing strata-should encroach more and more on the mountain flank and thus be generally at higher altitude and farther from the center of the valley in the later part of the period of accumulation. The sediments encountered in the deep well at Geneva tend to confirm this hypothesis: the coarsest detritus, consisting of boulders and cobbles, was encountered near the bottom of the well, and overlying aquifers are all of finer texture, although they are similarly of fluviatile origin.

The boulder bed that forms the developed aquifer in the deep well undoubtedly extends eastward toward the mouth of Provo Canyon, and probably is covered and overlapped by later Tertiary(?) gravels and then by coarse detritus of Pleistocene age. The strata of fine-textured material, including the lake clays shown in the log of the deep well, undoubtedly become thinner to the east. It is not known whether any of these fine-textured strata extends eastward as far as the mouth of the canyon, and the drilling of a deep well at that locality would provide valuable information on that question. In any case it is anticipated that the unconsolidated materials near the mouth of the canyon as well as in the lower part of the canyon will be predominantly coarse. These coarse materials are considered to constitute a common recharge area for the Pleistocene and older aquifers of the valley fill. But if all these aquifers have a common source of water, the differential head is not accounted for in the recharge area. Rather, it is believed that this differential head is developed within the area of artesian flow, as suggested below.

The fine-textured strata that intervene between the aquifers are far less permeable than the aquifers, but they are presumably slightly pervious. Israelsen and McLaughlin (1942, pp. 11-15) have shown by experiments in northern Utah that water moves upward through slightly pervious clays of the Lake Bonneville group overlying an artesian aquifer, and have noted a progressive decrease in head at successively higher levels in the clay bed. The loss of head in a 35 -foot clay bed amounted to 15.2 feet, and these authors conclude that this loss of head is accompanied by an upward movement of water through the clay, at an estimated rate of 200 to $250 \mathrm{gpm}$ per square mile of area.

The head measured in the several aquifers at Geneva may similarly be analyzed for indications of possible movement of water between aquifers. The differential head between the shallow and deep Pleistocene aquifers, amounting to 20 feet, is sufficient to suggest an appreciable upward movement of water from the deep aquifer. The water in underlying Tertiary(?) aquifers has a slightly greater head than that in the deep Pleistocene aquifer, and it is inferred that there may also be some upward movement from the Tertiary(?) aquifers.

Upward movement of water through the fine-textured materials that separate the aquifers may well account for the increased concentration of chemical constituents in the water at shallower depths. Samples from these fine-textured beds contain a large proportion of calcium carbonate, which is readily dissolved and would increase both the hardness and the total solids in the water of the upper aquifers. Chemical analyses indicate that the mineral constituents in the water in the deep Pleistocene aquifer are moderately greater than in the Tertiary(?) aquifers. In the shallow Pleistocene aquifer, where there is inferred to have been much greater upward movement of water from deeper strata, the waters are far more mineralized.

\section{WATER FROM DEFP GOURCES}

Wells at the Saratoga Springs resort discharge water at a temperature of about $110^{\circ} \mathrm{F}$ - - about $40^{\circ}$ higher than the water yielded by the Tertiary(?) aquifer in the Geneva Steel Co. deep well. Although these wells are less than 200 feet deep, they have been drilled in the vicinity of natural warm springs. The temperature indicates that these springs and wells yield water from deep sources, rising probably along a fault. The waters are not highly mineralized and may well come from valley fill similar to that penetrated by other wells, but at considerably greater depth. Seeps warm enough to keep snow melted throughout the winter have been reported by sheepherders along the east base of the Lake Mountains, south of Saratoga.

\section{CHEMICAL QUALITY OF WATER}

The present studies included no investigation of the geochemistry of the ground water. However, analyses have been made by various agencies of a relatively small number of samples of water from streams and wells. These analyses indicate that the waters of northern Utah Valley are generally calcium bicarbonate waters, commonly containing 200 to $400 \mathrm{ppm}$ of dissolved solids, and having hardness (as calcium carbonate) ranging from 150 to $300 \mathrm{ppm}$. The calcium bi- 
carbonate is derived from the limestones which are widespread over the drainage basin tributary to the Utah Lake Valley, particularly in the Wasatch Range.

The water in streams might be expected to have a higher concentration of chemical constituents when those streams are at low stage than when the stream discharge is high. At low stage, generally from August to the following March, much of the flow is derived from ground water, part of which is return flow from irrigation. On the other hand, the maximum flows are derived from melting snow on the drainage area during the spring and early summer.

Analyses of artesian well waters at the Geneva Steel plant indicate that water from the shallow Pleistocene aquifer generally is more concentrated than that from the deep Pleistocene aquifer, although the proportions of the individual constituents are similar. In turn, the water in the deep Pleistocene aquifer is more concentrated than that in the Tertiary(?) aquifer. The analyses are represented graphically in figure 22 . The increased concentration of mineral constituents in shallower strata, as well as the decreased artesian pressure of water in those strata, has been attributed (p. 89) to the upward movement of water from deep aquifers through shallower strata.

\section{MAXIMUM POTENTIAL DEVELOPMENT OF WATER RESOURCES}

What is the maximum potential development of water resources? The answer to this question is of vital importance to Utah's most densely populated region, because the ultimate limits of its agricultural and industrial economy will be set by the quantity of water that the Jordan River drainage basin can yield perennially for those developments. The history of water utilization (pp. 61-66) shows how the use of water in the drainage basin has been increased in the past century. In the early days of settlement, primary rights to the minimum flow of a stream constituted the only secure source of irrigation water when water was most needed; on the other hand, there were flood discharges into Great Salt Lake in nearly every year. At the present time the dependable yield of water throughout the irrigation season has been increased manyfold by storage in headwater lakes, by diversions from the Weber River drainage basin into Deer Creek reservoir, by manipulation of Utah Lake levels through floodgates and pumping, and by withdrawals from wells. For the last quarter century diversions into canals have constituted practically the entire output of Utah Lake, and the volume of these diversions has varied from 78,000 acre-feet in 1935 to 337,000 acre-feet in 1938. There has been practically no unused outflow from Utah Lake to Great Salt Lake since 1925.
As the dependable yield of the system has been increased, the individual water users have sought recognition and adjudication of their respective water rights. The rights have been defined for several tributaries, and designated "primary" or "secondary" or subdivided further according to various classes. Court decrees set the limits of use of water from the tributaries, and the associated canal companies that use water from Utah Lake lay claim to all water not used as well as the return flow from users holding these established rights. The suit of Salt Lake City et al. v. Tamar Anderson et al. seeks to bring about a comprehensive determination of the rights of all users to the surface water and ground water of Utah Lake and its tributary drainage basin. (See p. 63.)

Yet, there are large quantities of water that leave the Utah Lake drainage basin unused, although the surface water is generally regarded as fully appropriated, and many believe that the ground water should be similarly classified. The computed evaporation from the lake surface during nearly every year is greater than the quantity taken by pumping and gravity diversions for beneficial use. In 31 years (1916 to 1946, inclusive) the average annual evaporation was estimated to be about 315,000 acre-feet, compared with pumped and gravity diversions averaging 245,000 acre-feet a year. The evaporation from land areas and transpiration by native vegetation have not been estimated, but it is certain that the total in Utah Valley represents an additional natural loss of many thousand acre-feet each year.

These natural losses have a "priority" well above that of most of the established rights, and therefore cause a drastic reduction of the water available for beneficial use, particularly in dry years. In the drought year 1935, precipitation over the Utah Lake drainage basin was 55 to 70 percent of the long-term average, but because the natural evapotranspiration losses were not reduced in proportion, the computed inflow to Utah Lake was only 46 percent of average. Because of the reduced volume of water in Utah Lake and the smaller lake surface that year, the computed evaporation was only about 60 percent of average, but after this natural loss the users of Utah Lake were able to obtain less than 30 percent of the quantity normally used by them, and had to pump the lake nearly dry.

The excessive natural losses of water in Utah Valley, and particularly from Utah Lake, have long been recognized, and several methods have been proposed for reducing those losses. Some of these suggestions involve the concentration of Utah Lake storage in a smaller area by diking off the shallower parts of the lake. The Provo River project of the Bureau of Reclamation includes a proposed earth-and-rock-fill 
barrier across the mouth of Goshen Bay, a southwesterly arm of the lake; the dike, to be $5 \frac{1}{2}$ miles long, would reduce the surface area of the lake by 27,300 acres, which is about 20 percent of the lake surface at compromise level. It has also been proposed to dike off the smaller Provo Bay, along the east shore south of the city of Provo. Storage in deep and narrow canyon reservoirs, particularly in headwater areas, would be subject to less evaporation loss than in Utah Lake; the Deer Creek reservoir and headwater lakes thus are superior to Utah Lake in efficient storage. However, good additional reservoir sites are rare, and storage of anything like the volume in Utah Lake could be achieved only at great cost.

It is quite possible that the ground-water reservoir could be used to advantage in providing additional water for beneficial use. If the artesian pressure were sufficiently reduced by pumping from properly spaced wells, some of the water now lost by evapotranspiration in the lower part of Utah Valley might be diverted instead to beneficial use. And if water were withdrawn by pumping from the coarser gravels of the valley, it is likely that this water would be replaced by seepage from the streams. Thus water would be stored underground, rather than in Utah Lake, and evaporation losses would be at a minimum. If the ground-water reservoir were so utilized, the additional water salvaged from natural losses would be obtained at considerable cost, because of the pumping required. Indeed, any method of increasing the amount of water for utilization will entail large expenditures. Nevertheless the projects that will reduce evapotranspiration losses offer perhaps the only method of utilizing substantial additional quantities of water within the drainage basin, because these natural losses constitute most if not all the water still unappropriated.

A detailed knowledge of the ground-water reservoirs-the storage of water in aquifers and the rates and volumes of recharge, movement, and discharge of ground water-is prerequisite to an evaluation of the effectiveness of these projects in reducing evapotranspiration losses. It is necessary to know, for instance, how much water enters Utah Lake by upward movement from artesian aquifers before we can be assured that evaporation can be eliminated by diking off portions of Utah Lake. A knowledge of the sources and rates of movement of ground water lost by evapotranspiration in the land areas of Utah Valley must precede any successful developments for diverting that water to beneficial use. And if the ground-water reservoir is to be used for storage of any part of the water that now flows to Utah Lake, we must know the areas and potential rates of recharge to that reservoir $247743-54-7$ as well as the rates at which water could be transmitted through each aquifer.

Determination of the hydraulic characteristics of the several aquifers, in part from tests of existing wells but requiring also the drilling of several wells specifically for test purposes, would permit the calculation of the quantity of water stored underground, and of the rate and direction of movement of water in each aquifer. Tests similar to those undertaken by Israelsen in Cache Valley would determine the extent of upward movement from the artesian aquifers. Any attempt to develop the water now lost by evapotranspiration should be accompanied by hydrologic studies sufficiently comprehensive to prove that the water is being diverted as intended, and not from water users having established rights.

It has been demonstrated that an industry requiring large amounts of water can be established in Utah Valley without infringing upon the rights of other water users. The Geneva Steel Co. pumps water at the rate of $370 \mathrm{cfs}$ (240 million gallons per day), which is about 80 percent of the long-term average flow of the Provo River. The net consumptive use within the plant, however, is 10 to $12 \mathrm{cfs}$, of which about half is lost by evaporation from the reservoir, and the rest is consumed by coke quenching, descaling, cooling, and other processes.

The steel plant came late in the development of the valley, and therefore the water rights for the plant were necessarily acquired on a catch-as-catch-can basis. The Defense Plant Corp. had the advantage of excellent cooperation from holders of prior rights, and of a temporary lease on water from Deer Creek reservoir pending completion of the project and delivery to the ultimate users. Purchase of the property brought rights to 128 wells with a claimed combined flow of $4,400 \mathrm{gpm}$, plus rights in the irrigation season to the flow of several springs and drains yielding about 2,500 gpm on the average. These basic rights were sufficient to furnish the water for consumptive use.

In the development of artesian water supplies, all 128 wells on the property were plugged and sealed, and a dozen wells of large capacity were drilled near the center of the property. These wells yielded from 3,000 to 5,400 acre-feet annually between 1944 and 1948, which is somewhat more than the annual yield of the 128 wells during the period from 1938 to 1940 as computed by the State Engineer (2,900 to 3,400 acre-feet a year). This greater yield, however, has caused no observable loss in pressure head in private wells adjacent to the steel mill, for artesian pressures in the vicinity have fluctuated in response to precipitation and runoff in the same degree as other wells in Utah Valley. 
The steel-mill wells, because they are remote from the plant boundaries, cause less interference in many outlying wells than was created by individual wells that formerly discharged within the plant area.

The supply from wells was augmented in 1948 by production from a deep well, capable of yielding about 1,200 acre-feet a year. It was the only well to tap a Tertiary(?) aquifer in the vicinity of Geneva, and it caused no interference even in adjacent wells of the steel company, which tapped Pleistocene aquifers. ${ }^{4}$

The steel plant's vast requirements for circulating (nonconsumptive) water were met by diversions from the Provo River, either by pumping at the mouth of the canyon or by flow in the Lake Bottom Canal and West Union Canal. To insure that these diversions would not deplete the storage in Utah Lake, an agreement obligated the company to return to Utah Lake a quantity of water equivalent to the water diverted from the river, plus the nonirrigation flow of springs and drains, plus all water developed within the plant area by subsurface drains. Comparison of the inflow to Utah Lake before and after the plant was placed in operation shows that Utah Lake received quantities of water from the plant area substantially greater than the amount of water diverted from the river for plant use. (See table 28.) The excess may be due in part to climatic conditions, because the later years were somewhat wetter than the prewar years, and a greater flow from the area to the lake would be expected. But certainly a substantial part of the excess represents water salvaged by the company from loss by evapotranspiration within the steel plant area.

TABLE 28.-Annual flow to Utah Lake, in acre-feet, from Geneva Steel plant area

\begin{tabular}{|c|c|c|c|c|}
\hline Year & $\begin{array}{l}\text { Total inflow } \\
\text { to Utah } \\
\text { Lake }\end{array}$ & $\begin{array}{l}\text { Diverted } \\
\text { trom Provo } \\
\text { River }\end{array}$ & $\begin{array}{l}\text { Return flow } \\
\text { from plant } \\
\text { area }\end{array}$ & $\begin{array}{c}\text { Developed } \\
\text { by subsurface } \\
\text { drains }\end{array}$ \\
\hline \multicolumn{5}{|c|}{ Area Used for Agriculture } \\
\hline $\begin{array}{l}1938^{1}- \\
19399^{-} \\
1940\end{array}$ & $\begin{array}{l}18,800 \\
16,400 \\
14,400\end{array}$ & $\begin{array}{ll}2 & 16,700 \\
2 & 14,400 \\
2 & 13,000\end{array}$ & $\begin{array}{l}2,100 \\
2,000 \\
1,400\end{array}$ & \\
\hline \multicolumn{5}{|c|}{ Area Used for Steel Plant } \\
\hline $\begin{array}{l}1944^{3}- \\
1945^{5}- \\
1946^{5}- \\
1947^{3}- \\
1948^{3}-\end{array}$ & $\begin{array}{l}24,000 \\
25,900\end{array}$ & $\begin{array}{l}412,400 \\
14,500 \\
15,100\end{array}$ & $\begin{array}{r}9,500 \\
10,800\end{array}$ & $\begin{array}{l}5,700 \\
8,300\end{array}$ \\
\hline
\end{tabular}

1 From Watson, Gardner, and Harding survey.

2 Discharge from Lake Bottom and West Union Canals.

3 From records of the Geneva Steel Co. reservoir and Provo River by pumping at mouth of canyon.

$s$ Plant in operation for only a part of the year.

Since the completion of this report the Geneva Steel Co. (in 1950 and 1951) has drilled four more large wells into Tertiary(?) aquifers. These wells range in depth from 1,066 to 1,192 feet, and upon completion they yielded 2,200 to $3,000 \mathrm{gpm}$ each by artesian flow.
The table shows that the quantity developed by the subsurface drains (constructed to lower the high water table in the plant area, and thus agents for reducing the areal evapotranspiration) is from two to five times as great as the total return flow from the area in prewar years. In 1948 the Geneva Steel Co. released 3,300 acre-feet more water to the lake than was required to meet all its obligations with respect to diverted surface water, non-irrigation-season spring flow, and developed subsurface water. This surplus represented more than half the water yielded by the company's wells. Subsequent studies show that the steel plant has salvaged within its area enough water to balance its consumptive-use requirements of 8,000 to 9,000 acre-feet a year (Thomas, 1952).

It must be concluded, therefore, that the Geneva Steel Co. even with its enormous use of water, does not deplete the net available supplies as much as did the same property under an agricultural economy, and that the best prospect for development of additional water supplies in the valley lies in the possibility of similarly salvaging water now lost by natural processes. Such development requires an adequate knowledge of the hydrology, intelligent planning, and a wise management of the supply and its uses.

\section{SELECTED BIBLIOGRAPHY}

Abbe, Cleveland, 1901, The rainfall and evaporation of Great Salt Lake: Monthly Weather Rev., vol. 29, pp. 68-69.

Adams, T. C., 1932, Some hydrologic features of Great Salt Lake: Utah Eng., vol. 6, no. 5, pp. 1-3, 5.

- 1938, Recent depositions of salt from Great Salt Lake: Jour. Geology, vol. 46, pp. 637-646.

Allee, W. C., 1926, Some interesting animal communities of northern Utah: Sci. Monthly, vol. 23, pp. 481-495.

Alter, J. C., 1919, Normal precipitation in Utah: Monthly Weather Rev., September.

American Guide Series, 1942, Provo, Pioneer Mormon city: Binford and Mort Co., Portland, Oreg.

Anderson, G. E., 1915, Stream piracy of the Provo and Weber Rivers, Utah: Am. Jour. Sci., 4th ser., vol. 40, pp. 314-316.

Antevs, Ernst, 1925, On the Pleistocene history of the Great Basin: Carnegie Inst. Washington Pub. 352 (Quarternary climates), pp. 51-114.

- 1948, Climatic changes and pre-white man: Utah Univ. Bull., vol. 38, no. 20, pp. 168-191.

Atwood, W. W., 1909, Glaciation of the Uinta and Wasatch Mountains: U. S. Geol. Survey Prof. Paper 61.

Auerbach, H. S., 1943, Father Escalante's journal 1776-77: Utah Hist. Quart., vol. 11, pp. 64-66.

Baker, A. A., 1947, Stratigraphic sections in the Wasatch Mountains in the vicinity of Provo, Utah: U. S. Geol. Survey Oil and Gas Inv. Ser., prelim. chart 30.

Bancroft, H. H., 1889, History of Utah: The San Francisco Co., San Francisco, Calif.

Behle, W. H., 1942, The colonial nesting birds of Great Salt Lake: Utah Min. Soc. News Bull., vol. 3, no. 2, pp. 59-63. 
Blackwelder, Eliot, 1910, New light on the geology of the Wasatch Mountains, Utah: Geol. Soc. America Bull., vol. 21, pp. 517-542, 767.

1915, Post-Cretaceous history of the mountains of central western Wyoming: Jour. Geology, vol. 23, pp. 97$117,193-217,307-340$.

- 1931, Pleistocene glaciation in the Sierra Nevada and Basin Ranges: Geol. Soc. America Bull., vol. 42, pp. 865922.

1932, An ancient glacial formation in Utah: Jour. Geol., vol. 40, pp. 289-304.

1934, Supplementary notes on Pleistocene glaciation in the Great Basin: Washington Acad. Sci. Jour., vol. 24, no. 5, pp. 217-222.

1935, Summary of the pre-Cambrian rocks of Utah and Wyoming: Utah Acad. Sci. Proc., vol. 12, pp. 153-157.

1939, Pleistocene mammoths in Utah, and vicinity: Am. Jour. Sci., vol. 237, pp. 890-894.

Bryan, K., and Albritton, C. C., Jr., 1943, Soil phenomena as evidence of climatic changes: Am. Jour. Sci., vol. 241, pp. 469-490.

Butler, B. S., and others, 1920, Ore deposits of Utah: U. S. Geol. Survey Prof. Paper 111.

Calkins, F. C., and Butler, B. S., 1943, Geology and ore deposits of the Cottonwood-American Fork area, Utah: U. S. Geol. Survey Prof. Paper 201, pp. 38-40.

Call, R. E., 1885, Quaternary and Recent Mollusca of the Great Basin, with description of new forms: U. S. Geol. Survey Bull. 11.

Cameron, F. K., 1901, Application of the theory of solution to the study of soils: U. S. Dept. Agr., Bur. Soils.

Carlston, G. M., and Woolley, R. R., 1934, Some historical earthquakes in Utah (abstract): Utah Acad. Sci. Proc., vol. 11 , p. 171.

Carpenter, E., 1913, Ground-water in Box Elder and Tooele Counties, Utah: U. S. Geol. Survey Water-Supply Paper 333.

Clarke, F. W., 1924, Data of geochemistry: U. S. Geol. Survey Bull. 770, p. 159.

Clyde, G. D., 1931, Relationship between precipitation in valleys and on adjoining mountains of northern Utah: Monthly Weather Rev., pp. 113-117, March.

Cottam, W. P., 1926, An ecological study of the flora of Utah Lake, Utah (manuscript report in files of Chicago Univ. Grad. School Sci.).

1942, The flora of Great Salt Lake: Utah Min. Soc. News Bull., vol. 3, pp. 33-35.

Crawford, A. L., and Thackwell, F. E., 1931, Some aspects of the mudflows north of Salt Lake City, Utah: Utah Acad. Sci. Proc., vol. 8, pp. 97-105.

Daniels, L. L., 1917, On the flora of Great Salt Lake: An Naturalist, vol. 51, pp. 499-506.

Davis, W. M., 1903, The mountain ranges of the Great Basin: Harvard Coll. Mus. Comp. Zoology Bull., vol. 42, pp. 129177.

1905, The Wasatch, Canyon, and House Ranges, Utah: Harvard Coll. Mus. Comp. Zoology Bull., vol. 49, pp. 17-56. 1925, The Basin Range problem: Nat. Acad. Sci. Proc., vol. 11, no. 7, pp. 387-392.

1926, Biographical memoir Grove Karl Gilbert: Nat Acad. Sci. Mem. 5, vol. 21, 303 pp.

Eardley, A. J., 1933, Strong relief before block faulting in the vicinity of the Wasatch Mountains, Utah: Jour. Geology, vol. 41, pp. 243-267.
Eardley, A. J., 1934, Structure and physiography of the southern Wasatch Mountains, Utah: Michigan Acad. Sci. Papers, vol. 19, pp. 377-400.

- 1938, Sediments of Great Salt Lake, Utah: Am. Assoc. Petroleum Geologists Bull., vol. 22, pp. 1305-1411.

1939, Structure of the Wasatch-Great Basin region: Geol. Soc. America Bull., vol. 50, pp. 1277-1310.

Eardley, A. J., and Haas, Merrill, 1936, Oil and gas possibilities in the Great Salt Lake Basin: Utah Acad. Sci. Proc., vol. 13, pp. 61-80.

Eardley, A. J., and Hatch, R. A., 1940, Pre-Cambrian crystalline rocks of north-central Utah: Jour. Geology, vol. 48, pp. 58-72.

1940a, Proterozoic(?) rocks in Utah: Geol. Soc. America Bull., vol. 51, pp. 795-843.

Eckel, E. C., 1904, Salt industry in Utah and California: U. S. Geol. Survey Bull. 225, pp. 488-495.

Flowers, S., 1934, Vegetation of the Great Salt Lake region: Bot. Gazette, vol. 95, no. 3, pp. 353-418.

Forsling, C. L., 1931, A study of the influence of herbaceous plant cover on surface runoff and soil erosion in relation to grazing on the Wasatch Plateau in Utah: U. S. Dept. Agr. Tech. Bull. 220.

Frederick, E., 1924, The bacterial flora of Great Salt Lake (unpublished thesis in files of Utah Univ.), May.

Fremont, G. C., 1845, Report of the exploring expedition to the Rocky Mountains in the year 1842, and to Oregon and north California in the years 1843-44: Congressional documents, 28th Cong., 2d sess., S. Doc. 174.

Gale, H. S., 1914, Notes on the Quaternary lakes of the Great Basin, with special reference to the deposition of potash and other salines: U. S. Geol. Survey Bull. 540, pp. 399-406.

- 1915, Geologic history of Lake Lahontan: Science, new ser., vol. 41, pp. 209-211.

1916, Potash in Salduro salt deposit: Eng. and Min. Jour., vol. 102, pp. 780-782, October 28.

1917, Potash in 1916: U. S. Geol. Survey Mineral Resources U. S., 1916, pt. 2, pp. 73-171.

Gardner, D. I., 1936-47, Utah Lake and Jordan River distribution: Annual reports to the Utah State Engineer for the years 1936 to 1947 (nimeographed).

Gardner, F. D., and Jensen, C. A., 1901, Soil survey in Weber County, Utah: U. S. Dept. Agr., Bur. Soils.

Gianella, V. P., and Callaghan, Eugene, 1934, The earthquake of December 20, 1932, at Cedar Mountain, Nev., and its bearing on the genesis of Basin Range structure: Jour. Geology, vol. 42, no. 1, pp. 1-22.

Gilbert, G. K., 1875, Report on the geology of portions of Nevada, Utah, California, and Arizona: U. S. Geog. and Geol. Surveys W. 100th Mer. Rept. (Wheeler), vol. 3, pp. 17-187.

1876, On the outlet of Great Salt Lake: Am. Jour. Sci., 3d ser., vol. 11, pp. 228-229.

- 1878, The ancient outlet of the Great Salt Lake: Am. Jour. Sci., 3d ser., vol. 15, pp. 256-259.

- 1878a, The recent history of Great Salt Lake: Philos. Soc. Washington Bull., vol. 2, p. 187.

___ 1878b, Utah Lake: Johnson's New Illustrated Cyclopedia, edited by F. A. T. Barnard and A. Guyot, vol. 4, p. 1078.

1880, Outlet of Lake Bonneville: Am. Jour. Sci., 3d ser., vol. 19, pp. 341-349.

1880a, The Wasatch, a growing mountain: Philos. Soc. Washington Bull., vol. 2, p. 195. 
Gilbert, G. K., 1882, Contributions to the history of Lake Bonneville: U. S. Geol. Survey 2d Ann. Rept., 1880-81, pp. 167-200.

1883, A theory of the earthquakes of the Great Basin, with a practical application: Am. Jour. Sci., 3d ser., vol. 27, pp. 49-53.

- 1883a, Faults and earthquakes in Great Basin region: Science, 2d ser., vol. 2, pp. 580-581.

1883b, Pre-Bonneville climate: Science, $2 \mathrm{~d}$ ser., vol. 2, p. 170.

1885, The topographic features of lake shores: U. S. Geol. Survey 5th Ann. Rept., pp. 69-123.

- 1886, The inculcation of scientific method by example, with an illustration drawn from the Quaternary geology of Utah: Am. Jour. Sci., 3d ser., vol. 31, pp. 284-299.

1890, Lake Bonneville: U. S. Geol. Survey Mon. 1.

1928, Studies of Basin Range structure: U. S. Geol. Survey Prof. Paper 153.

Gilluly, James, 1928, Basin range faulting along the Oquirrh Range, Utah: Geol. Soc. America Bull., vol. 39, pp. $1103-1130$.

_ 1929, Possible desert-basin integration in Utah: Jour. Geology, vol. 37, pp. 672-682.

- 1932, Geology and ore deposits of the Stockton and Fairfield quadrangles, Utah: U. S. Geol. Survey Prof. Paper 173.

Gould, L. M., 1939, Glacial geology of Boulder Mountain, Utah: Geol. Soc. America Bull., vol. 50, pp. 1371-1380.

Hague, Arnold, and Emmons, S. F., 1877, Descriptive geology: U. S. Geol. Expl. 40th Par. Rept. (King), vol. 2.

Hansen, G. H., 1928, Hairy mammoth skeleton in Utah: Science, new ser., vol. 68 , p. 621 .

- _ 1934, An interpretation of past climatic cycles from observations made of Utah Lake sediments: Utah Acad. Sci. Proc., vol. II, pp. 161-162.

Hart, R. A., 1927, Some human influences on the oscillations and trend of Great Salt Lake: Utah Eng., vol. 1, no. 10, pp. $1-3,6$.

Hayes, J. J., 1942, Great Salt Lake and its economic importance: Utah Min. Soc. News Bull., vol. 3, pp. 11-23.

Hintze, F. F., 1913, A contribution to the geology of the Wasatch Mountains, Utah: New York Acad. Sci. Annals, vol. 23, pp. 85-143.

Howell, E. E., 1875, Report on the geology of portions of Utah, Nevada, Arizona, and New Mexico examined in the years 1872 and 1873: U. S. Geog. and Geol. Surveys, W. 100th Mer. Rept. (Wheeler), vol. 3, pp. 227-301.

Huff, E. N., 1947, Memories that live, Utah County centennial history, pp. 161, 190, 231, and 268, Springville, Utah.

Hunt, C. B., Creamer, A. S., and Fahey, J. J., 1949, A newly discovered type of clay deposit in Utah: Washington Acad. Sci. Jour., vol. 39, no. 4, pp. 120-122.

Hunt, C. B., and Sokoloff, V. P., 1950, Pre-Wisconsin soil in the Rocky Mountain region, a progress report: U. S. Geol. Survey Prof. Paper 221-G.

International Geological Congress, 16th sess., 1933, The Salt Lake region: Guidebook 17, Excursion C-1, 149 pp.

Irving, Washington, 1837, The Rocky Mountains-or scenes, incidents, and adventures in the Far West-digested from the Journal of Capt. B. L. E. Bonneville of the Army of the United States: Carey, Lea, and Blanchard, 2 vols., Philadelphia.

Israelsen, O. W., and McLaughlin, W. W., 1942, Drainage of land overlying an artesian ground-water reservoir: Utah Agr. Exper. Sta. Bull. 242, pp. 11-15.
Ives, R. L., 1946, Desert ripples: Am. Jour. Sci., vol. 244, pp. 492-501, July.

Jacob, C. E., 1946, Drawdown test to determine effective radius of artesian well: Am. Soc. Civil Eng. Trans., vol. 112, pp. 1047-1063.

Jennings, D. S., Fletcher, J. E., Wallace, M. H., Wilson, L., and Zobell, I. D., 1946, Soil survey of the Salt Lake area: Soils and Agr. Eng. Ser., 1936, no. 22.

Jensen, C. A., and Strahorn, A. T., 1905, Soil survey of the Bear River area, Utah: U. S. Dept. Agr., Bur. Soils.

Jensen, J. M., 1924, History of Provo: New Century Printing Co., Provo, Utah, 414 pp.

Jones, D. T., 1944, Two protozoans from Great Salt Lake: Utah Univ. Bull., vol. 35, nos. 8, 515.

Jones, J. C., 1925, The geologic history of Lake Lahontan: Carnegie Inst. Washington Pub. 352.

Judd, N. M., 1926, Archeological observations north of the Rio Colorado: Bur. Am. Ethnology Bull. 82.

Kay, G. F., 1916, Gumbotil, a new term in Pleistocene geology: Science new ser., vol. 44 , pp. 637-638.

- 1931, Classification and duration of the Pleistocene period: Geol. Soc. American Bull., vol. 42, pp. 425-466.

Kay, G. F., and Leighton, M. M., 1933, Eldoran epoch of the Pleistocene period: Geol. Soc. America Bull., vol. 44, pp. 669-674.

Kellogg, C. E., 1936, Development and significance of the great soil groups of the United States: U. S. Dept. Agr. Misc. Pub. 229.

Keyes, Charles R., 1917, Orographic origin of ancient Lake Bonneville; Geol. Soc. America Bull., vol. 28, pp. 164, 351374.

King, Clarence, 1878, Systematic geology: U. S. Geol. Expl. 40th Par. Rept., vol. 1.

Kirkpatrick, R., 1934, The life of Great Salt Lake with special reference to the algae (unpublished thesis in files of Utah Univ.), May.

1936, Some diatoms of Great Salt Lake: Torrey Bot. Club Bull., vol. 63, pp. 157-166.

Lawson, A. C., 1915, The epigene profiles of the desert: California Univ., Dept. Geol. Sci. Bull., vol. 9, pp. 23-48.

Lee, W. T., 1915, Guidebook of the western United States, Part $B$, The overland route, with a side trip to Yellowstone Park: U. S. Geol. Survey Bull. 612.

Leggette, R. M., and Taylor, G. H., 1932, Ground-water supplies in the vicinity of Salt Lake City, Utah: U. S. Dept. Interior Press Mem. 64395, July 23.

1937, Geology and ground-water resources of Ogden Valley, Utah: U. S. Geol. Survey Water-Supply Paper 796-D.

Leighton, M. M., 1931, The Peorian loess and the classification of the glacial drift sheets of the Mississippi Valley: Jour. Geology, vol. 39, pp. 45-53.

Leverett, Frank, 1910, The comparison of the North American and European glacial deposits: Zeitschr. Gletscherkunde, vol. 4, pp. 241-295, 321-342.

Lockerbie, C. W., 1942, Bird life about Great Salt Lake: Utah Min. Soc. News Bull., vol. 3, no. 2, pp. 64-66.

Marbut, C. F., 1935, Soils of the United States: U. S. Dept. Agr., Atlas Am. Agr., pt. 3.

Marsell, R. E., 1931, Salient geological features of the Traverse Mountains, Utah: Utah Acad. Sci. Proc., vol. 8, pp. 106110. 
Martin, Gail, 1938, Sodium sulphate from the shore of Great Salt Lake: Eng. and Min. Jour., vol. 139, p. 55, June.

Mathews, A. A. L., 1930, Origin and growth of the Great Salt Lake oolites: Jour. Geology, vol. 38, pp. 633-642.

Maxey, G. B., 1946, Geology of part of the Pavant Range, Millard County, Utah: Am. Jour. Sci., vol. 244, pp. 324356.

Meinzer, O. E., 1922, Map of the Pleistocene lakes of the Basin and Range province and its significance: Geol. Soc. America Bull., vol. 33, pp. 541-552.

Mendenhall, W. C., 1920, Memorial of Grove Karl Gilbert; Geol. Soc. America Bull., vol. 31, pp. 26-64.

Merriam, J. C., 1918, Evidence of mammalian paleontology relating to the age of Lake Lahontan: California Univ. Press, 321 pp., Berkeley.

Moscheles, J., 1922, Der Lake Bonneville und das eiszeitliche Kilma: Zeitschr, Gletscherkunde, Band 12, Heft 3-4, pp. 166-167.

Nelson, J. W., and Eckmann, E. C., 1913, Soil survey of the Cache Valley area, Utah: U. S. Dept. Agr., Bur. Soils.

Nolan, T. B., 1927, Potash brines in the Great Salt Lake desert, Utah: U. S. Geol. Survey Bull. 795-B.

— 1935, The Gold Hill mining district, Utah: U. S. Geol. Survey Prof. Paper 177.

Pack, F. J., 1926, New discoveries relating to the Wasatch fault: Am. Jour. Sci., 5th ser., vol. 11, pp. 399-410.

Packard, A. S., Jr., 1873, Insects inhabiting Great Salt Lake and other saline and alkaline lakes in the West: U. S. Geol. and Geog. Survey Terr. 6th Ann. Rept., (Hayden), pp. 744-748.

- 1876, On the supposed ancient outlet of Great Salt Lake: U. S. Geol. and Geog. Survey Terr. (Hayden) Bull. 5, pt. 2, pp. 413-414.

- 1876a, The Great Salt Lake in former times: Am. Naturalist, vol. 10, pp. 675-681.

1879, The sea weeds of Great Salt Lake: Am. Naturalist, vol. 13, pp. 701-703.

Paul, J. H., and Baker, F. S., 1925, The floods of 1923 in northern Utah: Utah Univ. Bull., vol. 15, no. 3, March.

Powell, J. W., 1879, Lands of the arid region of the United States: U. S. Geog. and Geol. Survey Rocky Mtn. Region Rept., (Powell), p. 124.

Rees, D. M., 1942, Animals living in the Great Salt Lake: Utah Min. Soc. News Bull., vol. 3, no. 2, pp. 57-58.

Reynolds, R. V. R., 1911, Grazing and floods-a study of conditions in the Manti National Forest, Utah: U. S. Forest Service Bull. 91.

Richardson, G. B., 1905, Natural gas near Salt Lake City: U. S. Geol. Survey Bull. 260, pp. 480-483.

-_ 1906, Underground water in the valleys of Utah Lake and Jordan River, Utah: U. S. Geol. Survey Water-Supply Paper 157, pp. 36, 50, 51, 59-75.

Rower, A. S., 1928, A "fossil" camel recently living in Utah: Science, M. Sec., vol. 68, pp. 19-20.

Russell, I. C., 1876, On the formation of lakes: Pop. Sci. Monthly vol. 9, pp. 539-546.

_ 1883, Playas and playa lakes: Pop. Sci. Monthly, vol. 22, pp. $380-383$.

___ 1883a, Sketch of the geological history of Lake Lahontan, a Quaternary lake of northwestern Nevada: U. S. Geol. Survey 3d Ann. Rept., pp. 189-235.

_- 1884, Lakes of the Great Basin: Science, new ser., vol. 3, pp. 322-323.

_ 1885, Geological history of Lake Lahontan, a Quaternary Lake of northwestern Nevada: U. S. Geol. Survey Mon. 11.
Russell, I. C. 1889, Quaternary history of Mono Valley, Calif.: U. S. Geol. Survey 8th Ann. Rept., pp. 261-394.

- 1895, Lakes of North America, Ginn \& Co., Boston, 125 pp.

- 1895a, Present and extinct lakes of Nevada: Nat. Geog. Soc., Nat. Geog. Mon. 1, no. 4, pp. 101-136.

Sanchez, A. M., 1904, Soil survey of the Provo area, Utah: U. S. Dept. Agr., Bur. Soils field operations, 1903, pp. 11, 12, 15, 17

Schneider, Hyrum, 1925, A discussion of certain geologic features of the Wasatch Mountains: Jour. Geology, vol. 33, pp. 28-48.

Shantz, H. L., and Zon, R., 1924, Natural vegetation: U. S. Dept. Agr. Atlas Am. Agr.

Sharp, R. P., 1938, Pleistocene glaciation in the Ruby-East Humboldt Range, northeastern Nevada: Jour. Geomorphology, vol. 1, no. 4, pp. 296-323.

1939, The Miocene Humboldt formation in northeastern Nevada: Jour. Geology, vol. 47, no. 2, pp. 133-160.

Shelley, G. F., 1945, Early history of American Fork; American Fork City. 152 pp.

Shenon, P. J., 1935, Utah earthquake of March 24, 1934 (abstract): Washington Acad. Sci. Jour., vol. 25, pp. 508-509.

Smith, E. R., 1942, Early man in the Great Salt Lake area: Utah Min. Soc. News Bull., vol. 3, no. 2, pp. 27-32.

Spieker, E. M., 1946, Late Mesozoic and early Cenozoic history of central Utah: U. S. Geol. Survey Prof. Paper 205-D, pp. 149-155.

Spieker, E. M., and Billings, M. P., 1940, Glaciation in the Wasatch Plateau, Utah: Geol. Soc. America Bull., vol. 51, pp. 1173-1197.

Spurr, J. E., 1901, Origin and structure of the Basin Ranges: Geol. Soc. America Bull., vol. 12, pp. 217-270.

Stansbury, Howard, 1852, Exploration and survey of the valley of the Great Salt Lake of Utah: Congressional documents 32d Cong., special sess., S. Doc. 3, March.

Steward, J. H., 1933, Archaeological problems of the northern periphery of the Southwest: Mus. Northern Arizona Mus. Notes, vol. 5 .

- 1933a, Early inhabitants of western Utah, Part 1, Mounds and house types: Utah Univ. Bull. 23, no. 7.

1936 Pueblo material culture in western Utah: Univ. New Mex. Bull. 287, Anthropol. Ser., vol. 1.

1937, Ancient caves of the Great Salt Lake region: Smithsonian Inst, Bur. Am. Ethnology Bull. 116.

Stokes, W. L., and Hansen, G. H., 1937, Two Pleistocene musk-oxen from Utah: Utah Acad. Sci. Proc., vol. 14, pp. 63-65.

Stover, A. P., 1903, Irrigation in Utah Lake drainage system, in Report of irrigation investigations in Utah: U. S. Dept. Agr. Bull. 124, pp. 93, 107-144, 134, 135.

Strahorn, A. T., Stucki, H., and Jennings, D. S., 1922, Soil survey of the Delta area, Utah: U. S. Dept. Agr., Bur. Soils Field operations for 1919.

Stratton G. M., 1929, Utah's salt industry: Utah Eng, vol. 3, no. 5 , pp. 1-3.

Surface-water reports of the United States, 1914-47, Part 10, The Great Basin: U. S. Geol. Survey Water-Supply Papers for the years 1914-47.

Talmage, J. E., 1896, The Great Salt Lake, past and present: Utah Univ. Quart. 2, pp. 73-82, 137-152.

Taylor, G. H., 1937, Ground water in Utah: Am. Geophys. Union Trans., 18th Ann. Meeting, pt. 2, pp. 536-541.

Taylor, G. H., and Thomas, H. E., 1937, Ground water in the vicinity of Woods Cross, Davis County, Utah, (manuscript report in files of U. S. Geol. Survey). 
Taylor, G. H., and Thomas, H. E., 1939, Artesian water levels and interference between artesian wells in the vicinity of Lehi, Utah: U. S. Geol. Survey Water-Supply Paper 836-C, pp. 107-156.

Teele, R. P., 1903, Irrigation from Jordan River, in Report of irrigation investigations in Utah: U. S. Dept. Agr. Exper. Sta. Bull. 124, p. 80.

Thomas, H. E., 1946, Ground water in Tooele Valley, Utah: Utah State Eng. 25th Bienn. Rept., pp. 116-118.

1952, Utah Valley, in Status of development of selected ground-water basins in Utah: Utah State Eng. Tech. Pub. 7, pp. 71-76.

Thomas, H. E., and Nelson, W. B., 1948, Ground water in the East Shore area, Utah; Part 1, Bountiful district, Davis County: Utah State Eng. Tech. Pub. 5, Utah State Eng. 26th Bienn. Rept., pp. 59-206.

Thomas, O. D., 1937, Salt in the valley of the Great Salt Lake: Compass, vol. 17, no. 3, pp. 163-166.

United States Geological Survey, 1916, Potash in lake muds of western Utah: Press Bull. 271, May.

- 1947, Surface water supply of the United States 1945, Part 10, The Great Basin: U. S. Geol. Survey Water Supply Paper 1040.

Utah Agricultural Experiment Station, 1945(?), Land classification map, Utah and Goshen Valleys, Utah County.

Utah State Agricultural College Experiment Station, 1931, Report of special flood commission appointed by Gov. G. H. Dern, Circ. 92.

Varnes, D. J., and Van Horn, R., 1951, Surficial geology of the Oak City area, Millard County, Utah: Unpublished manuscript in files of U. S. Geol. Survey.
Vorhies, C. T., 1917, Notes on the fauna of Great Salt Lake: Am. Naturalist, vol. 51, p. 494.

Watson, H. J., Gardner, D. I., and Harding, S. T., 1941, Records of measurements of surface flow to Utah Lake and Provo Bay: in Board of Canal Presidents of Associated Canals Rept. 8 (unpublished), tables 5-8.

Wheeler, G. M., 1876, Geological atlas projected to illustrate geographical exploration and surveys west of the 100th meridian. Gilbert, G. K., Marvine, A. R., and Howell, E. E., sheet 12, Restored outline of Lake Bonneville, Utah and Nevada.

Williams, J. S., 1948, Geology of the Paleozoic rocks, Logan quadrangle, Utah: Geol. Soc. America Bull., vol. 59, no. 11, pp. 1121-1163.

Wilmarth, M. G., 1938, Lexicon of geologic names of the United States: U. S. Geol. Survey Bull. 896, p. 1897.

Woolley, R. R., 1924, Water powers of the Great Salt Lake basin: U. S. Geol. Survey Water-Supply Paper 517.

1927, Some salient features connected with the fluctuations in level of Great Salt Lake: Utah Eng., vol. 1, no. 8, pp. 1-3.

1944, An engineer looks at Great Salt Lake: Civil Eng., vol. 14, pp. 332-334, New York.

1946, Cloudburst floods in Utah, 1850-1938: U. S. Geol. Survey Water-Supply Paper 994.

Woolley, R. R., and Alter, J. C., 1938, Precipitation and vegetation: Am. Geophys. Union Trans., pp. 604-607.

ZoBell, C. E., Anderson, D. Q., and Smith, W. W., 1937, The bacteriostatic and bactericidal action of Great Salt Lake water: Jour. Bacteriology, vol. 33, pp. 253-262. 


\section{INDEX}

A

Abstract

Acknowledgments

Alluvial deposits, ground water in of Provo age of Quaternary age

properties of

Alluvial-fan deposits, properties of uses of

Alluvium, mechanical analysis of

pollution of water in

recharge area for ground water in water table in.

Almond, $\mathbf{H y}$, colormetric tests by

Alpine formation, chemical analyses of comparison with Provo formation. description.

volume of

water-bearing propertles of

Page

80-82

28-29

12

7

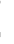

34

34

33-34

$17-20$

37,40 Amican Fork River-.............. 6, 7-8, 24, 28, 29, 36-37, 42, 52, 60-61, 67, 68

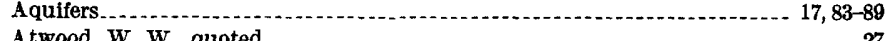

Atwood, W. W., quoted ............. 27

B

Base course materials.

$53,56,57-58$

Battle Creek

Bench gravel, properties of uses of.

$60-61,67,68$

Bibllography

volume of

Brannock, W. W., analyses by

C

Calcareous tufa

Calcite.

Calclum blcarbonate in water.

Calcium carbonate deposits ..... .

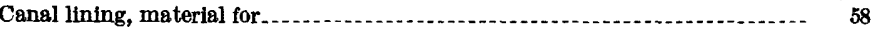

Chemical analyses of water.

Clarke, F. W., quoted.......... 32, 34

Clay, analyses of . 20,59 chemical analyses of

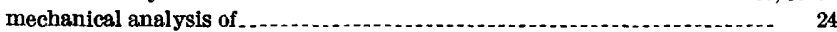

of the Alpine formation.

of the Provo formation......... 24-25

uses of

Climate, description evolution of.

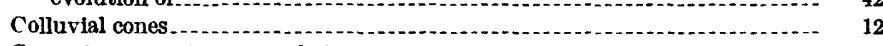

Concrete aggregate, materials for

Construction materials, processed, description ........................... 58-60

unprocessed, description............. $53-58$

Cox, Jacob, well of

Davidson, Norman, analysis by

Deer Creek reservoir, description

Deer Creek reservoir, water loss from

Delta deposits.

Differential head of aquifers. . .

Diversions from streams, prior to 1880

status in 1903

status in 1947

Drains, description of

Drought Relief Administration, well of

Droughts

Dry Creek
Pag

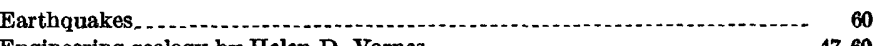

Engineering geology by Helen $D$. Varnes.

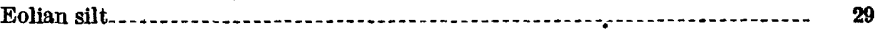

Erosion, geologic aspects of

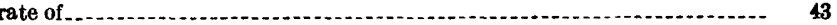

Evaporation, computation of ............. 69-71 table showing

Evolution of Utah Valley

\section{F}

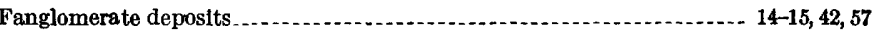

Farming ....... 5

Faults_...

Field work

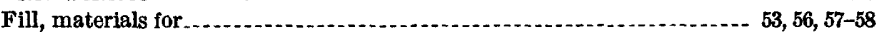

Flood control, geologic aspects of

Flowing wells, deep aquifer for

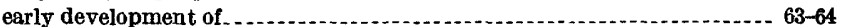

fluctuation in artesian pressure in

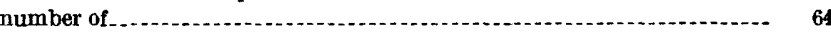

shallow aquifer for......... 83

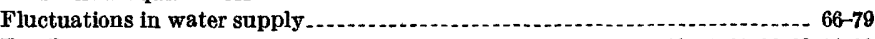

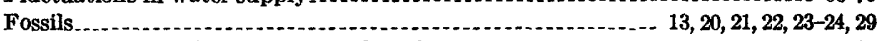

Foster, Margaret D., chemical analysis by $\ldots \ldots \ldots$

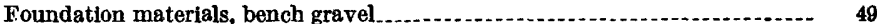

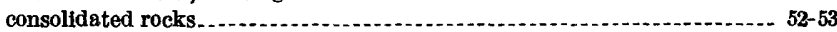
mixed gravel and sand..... 50

properties affecting ............. 48-49

river gravel

sand..... 50

silt and clay . . . . . .

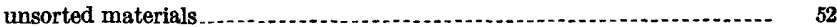

Fugal Springs.

Fulton decree.

Fur hunters.

G

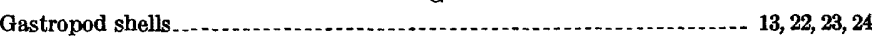

Geneva Steel Co., reservoir of

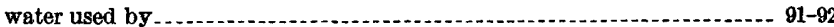

well of

Geochemical studies........... $31-36$

Geography, economic

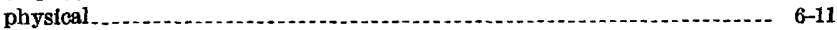

Geological history

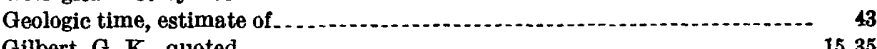

Gilbert, G. K., quoted

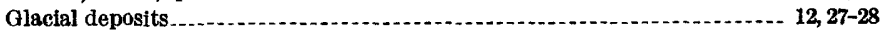

Glacial lake deposits

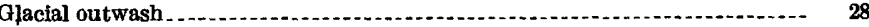

Goshen Bay - .

Gravel, map of deposits

mechanical analysis of ............... 22

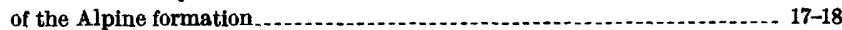

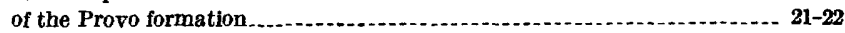

See also bench gravel, gravel and sand.

Gravel and sand, mixed, properties of .

mixed, uses of

Cround water, sources of .

Ground-water districts.

Hansen, G. H., quoted...... 21

Head of the water, measurement of

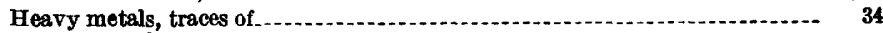

Highland bench. 
Highland ground-water district

History, geological structural.

Huff, Lyman, colorimetric tests by

Hunt, Charles B., General geology

Hydraulic characteristics of aquifiers, determination of

Hydrographs, of discharge from springs

of streams.

of wells.

\section{I}

Indians

Industry.

Inflow, estimates of

Introduction.

$\mathbf{J}$

Jacobson and Smith, well of

Jordan River

$\mathbf{L}$

Lake Bonneville, age of

salinity of

size of

Lake Bonneville group, description.

water-bearing properties of

Lake deposits.

Lake ground-water district

Lake monument, altitude of

Lake Mountains.

Lake silt and clay, uses of

Landforms.

Lehi Irrigation Co., well of

Limestone for flux.

Little Cottonwood stock

\section{$\mathbf{M}$}

Mammoth

Mapping, methods used in

Mesozoic rocks.

Mollusks, in the Provo formation

Moraines

Mormon settlers.

Morse, Hon. C. W., quoted

Morse decree.

Movement of ground water

-..............

$\mathrm{N}$

Natural discharge from aquifers.

$\mathrm{N}$

Natural losses of water

Near-shore deposits, comparison with offishore deposits.................... 33-34

o

Offshore deposits, comparisons with near-shore deposits... . ................. 33-34

Orem, $\log$ of city well for .

26-27

Orem bench $6,8,21-23,35,50-51,57,81$

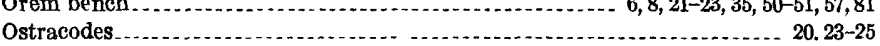

\section{$\mathbf{P}$}

Paleozoic rocks $11,53,57-58$

Peat...

Piezometric surface, of the deep aquifer of the shallow aquifer

Pollution, of ground water tests for

Population.

(n)

(1) tables showing

Pre-Lake Bonneville Pleistocene deposits, description. ....... 14-17

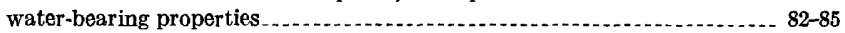

Previous studies.

Priorities for water

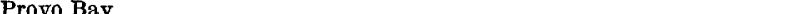

Page

Provo formation, chemical analyses of ............................... 31, 32, 33, 34

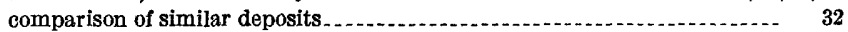
comparisons with Alpine formation........ $33-34$

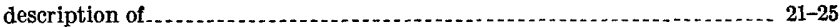
volume of

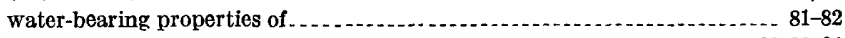

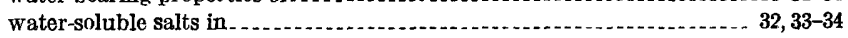

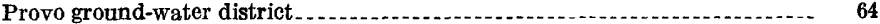

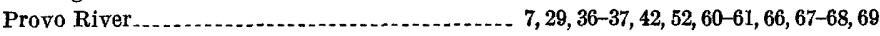
Provo River project. ...........

Q

water

Quarries for gravel and sand, map............... 54

Quaternary deposits in the mountains...................................... 12

R

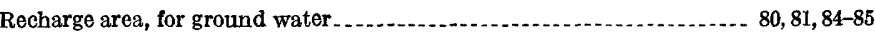

in alluvial deposits.

of aquifers . . . .

Reservoir control

Reservoirs . . . . . . . . .

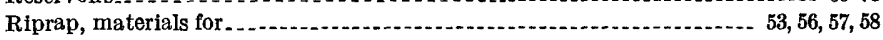

River gravel, properties of ... _.

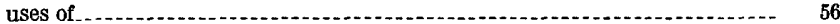

Rocks, for foundation materials, properties of

\section{$S$}

Salt Lake formation, description of

$13-14$

volume of

Salvage of water.

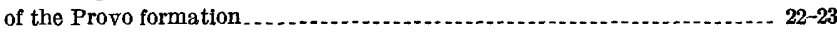

properties of

uses of

Sand bars

Saratoga Springs........

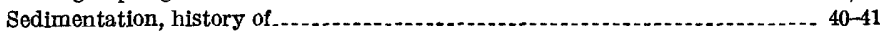

Shale, Paleozic uses of

Silt, chemical analyses of ........ mechanical analysis of

of the Provo formation............... 23-24

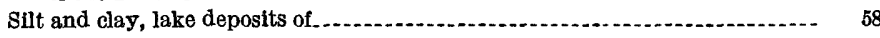
of the Alpine formation.................................................... 20

properties of

uses of

Soil genesis, factors of

Soll profile, depth of

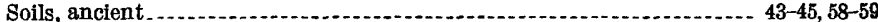
evolution of

modern....... 45

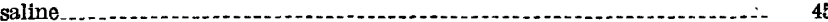

Source rocks

South Fork Provo River..... 67, 68

Spanish explorers

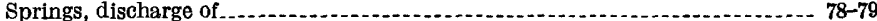

in Utah Lake

Stover, A. P., quoted

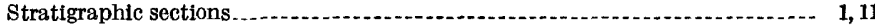

Stratigraphy

Stream discharge, records of ...

Streams, fiuctuation in water of

hydrographs of flow $\ldots$

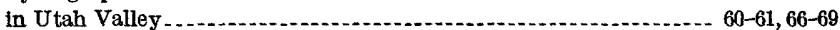

Structure

Subsurface inflow to Utah Lake. . . .

Surface inflow, records of ............ 71-72

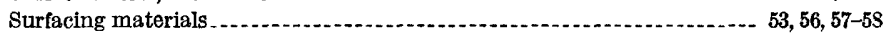

Swain, F. M., quoted.

T

Talus cones ................................ 12

Tertiary deposits, water-bearing properties.

Tertiary rocks......

Thomas, H. E., Water resources 
Topography, evolution of.-

Towns

Transportation

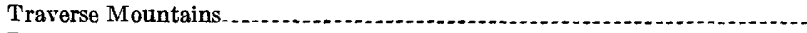

Travertine. See calcareous tufa

Tuff-

$\mathrm{U}$

Union Pacific Railroad, well of

\section{$\mathrm{U}$}

Utah Lake, area of

capacity of

chemical analysis of water from

description of

diversions from.

evaporation from.

inflow and outflow

natural losses of water

salinity of .

springs in.

subsurface inflow

surface inflow into ...

$\mathrm{Utah}$ Valley, description of

origin of.

stratigraphic section of

structural geology of

Valley fill, depth of.

Valley sediments, relation to source rock

Varnes, Helen D., Engineering geology

Vertebrate fossils.

Volumes of the formations, comparison of

W

Wasatch Range, description stratigraphic section of.
Page

5,6

5,6

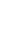

37-38

12-13

47-60

4,29
Page temperature of

Water level, fluctuations of, long term ......................................... 77-78

fluctuations of, seasonal

Water resources by Harold E. Thomas. maximum potential development of $\ldots \ldots \ldots$

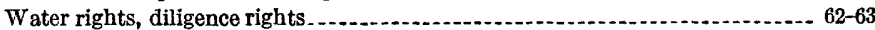
laws concerning.

Water-soluble salts, analyses of ........................................... 32, 33-34

Water supply, fluctuations, in reservoirs........................................ 69-73

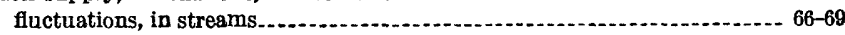

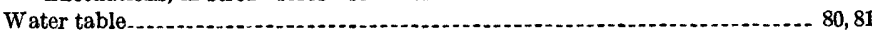

Water utilization, history of ..... 61-66

Weathering, factors controlling............................................ 46

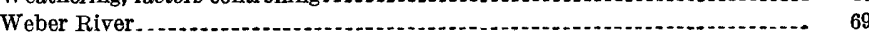

Well discharge, relation to fluctuation of water levels.

total.

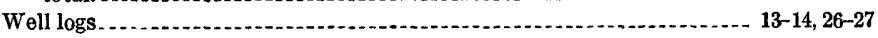

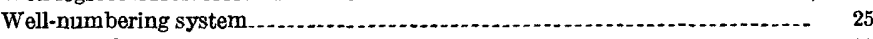

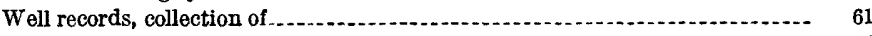

Wells, classification of

discharge of ........................... $73-75$

discharge of, from deep sources.

discharge test of ............................ 86-87

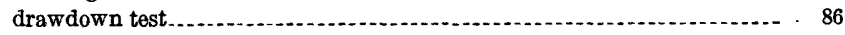

early development of

fluctuations in artesian pressure

fluctuations in water level ............................................. 76-77

long-term fluctuations in .

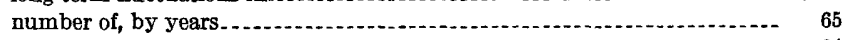

status of, in $1903 \ldots$

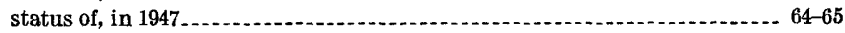

yield of, in Highland district.

in Provo district................. 75

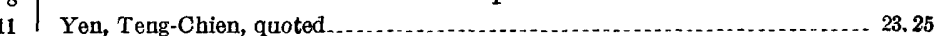


